Suchtartiges Essverhalten in der deutschen Allgemeinbevölkerung, bei Personen mit morbider Adipositas und leistungsorientierten Ausdauersportlern - Untersuchungen mit der Yale Food Addiction Scale 2.0

\author{
Dissertation \\ zur Erlangung des Doktorgrades \\ der Fakultät für Agrarwissenschaften \\ der Georg-August-Universität Göttingen
}

vorgelegt von

Carolin Maria Hauck

geboren in Schweinfurt

Göttingen, Mai 2018 
D 7

1. Referentin/Referent: PD Dr. med. Thomas Ellrott

2. Korreferentin/Korreferent: Prof. Dr. Norbert Hagemann

Tag der mündlichen Prüfung: 09. Mai 2018 


\section{Inhaltsverzeichnis}

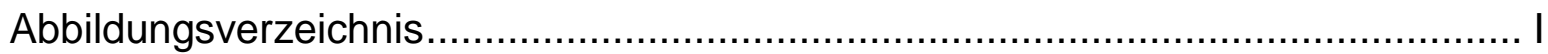

Tabellenverzeichnis..............................................................................

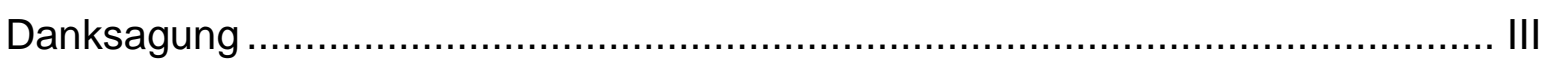

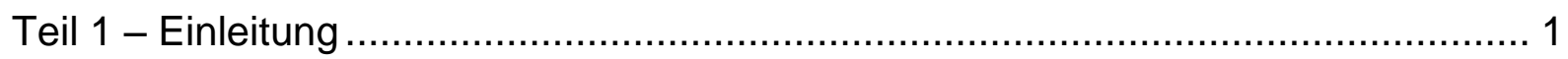

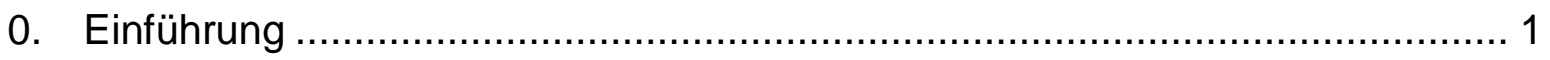

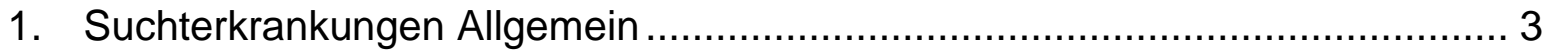

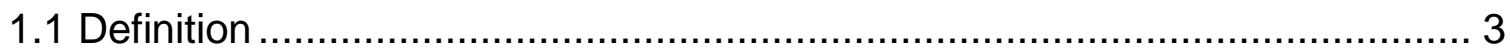

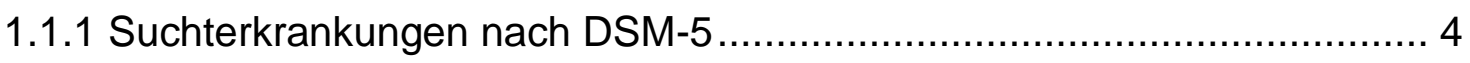

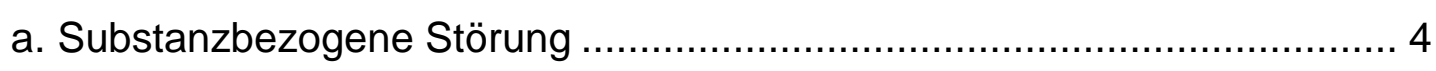

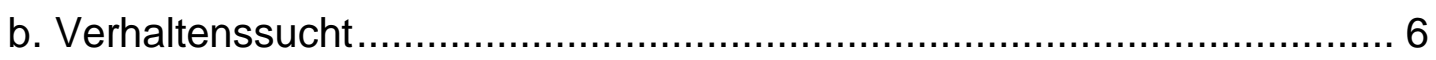

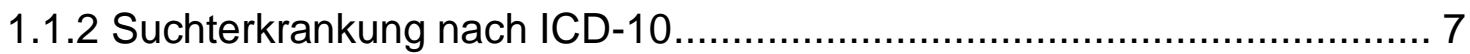

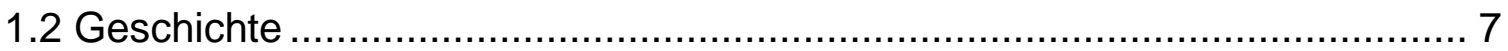

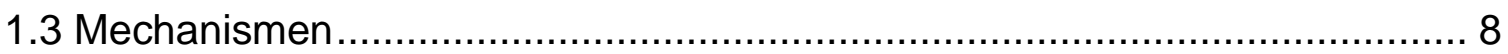

1.4 Protektoren und Risikofaktoren .................................................. 10

1.5 Konsequenzen des Substanzgebrauchs ......................................... 11

2. Suchtartiges Essverhalten/Food Addiction ........................................ 11

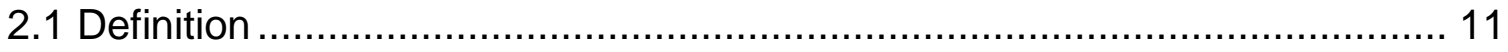

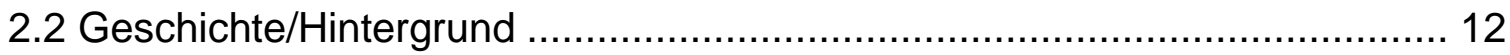

2.3 Diagnostische Kriterien für Substanzgebrauchsstörungen und

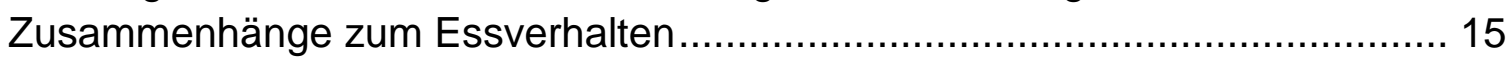

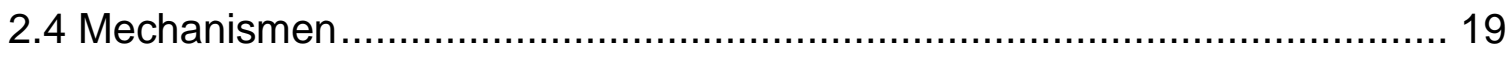

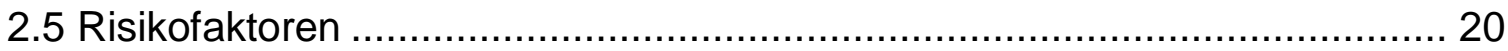

2.6 Ergebnisse aus Studien zu suchtartigem Essverhalten, gemessen mittels

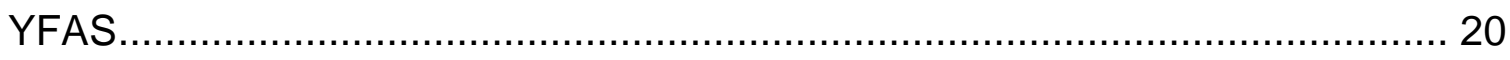

2.7 Sport, Sportsucht und Food Addiction............................................. 23

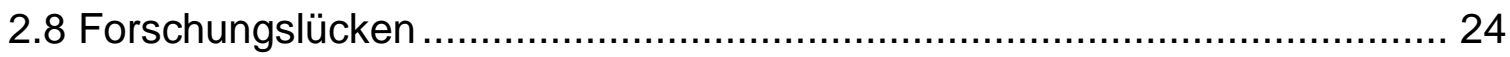

Literaturverzeichnis Teil 1 - Einleitung ....................................................... 25

Teil 2 - Eigene Publikationen zu Food Addiction.......................................... 51

3. Prevalence of Food Addiction as Measured with the Yale Food Addiction Scale 2.0 in a Representative German Sample and Its Association with Sex, Age and Weight Categories.

4. „Food Addiction“, gezügeltes Essverhalten, mentaler Gesundheitsstatus und Heißhungersymptome bei morbider Adipositas. 
5. Food Addiction, exercise dependence and perfectionism in amateur athletes 53

5.10 POSTER 'Food Addiction' nicht nur bei Adipositas?!

6. ,Food Addiction': - Suchtartiges Essverhalten - Stand der Forschung mit der Yale Food Addiction Scale ........................................................................ 74

7. Zusammenhänge zwischen Genuss und Übergewicht/ Adipositas................. 75

Teil 3 Diskussion und Schlussfolgerung ............................................................ 76

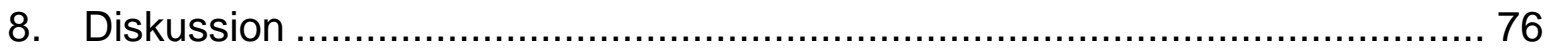

8.1 Food Addiction und Makronährstoffe ..................................................... 77

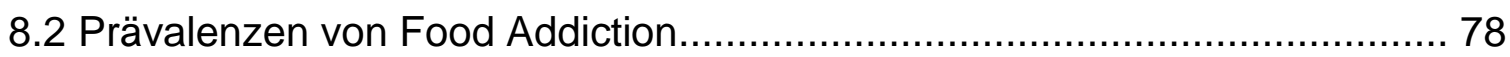

8.3 Food Addiction und BMI-Kategorie .................................................... 80

8.4 Food Addiction und Geschlecht ............................................................. 83

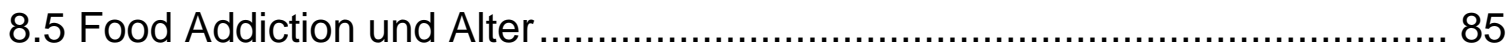

8.6 Symptomausprägungen von Food Addiction ......................................... 87

8.7 Einflussfaktoren auf Food Addiction ........................................................... 98

8.8 Food Addiction und Sportsucht ......................................................... 102

8.9 Überschneidung Food Addiction und Essstörungen ................................ 104

8.10 Food Addiction-Raten im Verlauf ..................................................... 106

8.11 Kritik am Konzept Food Addiction .................................................. 107

8.12 Kritik an der Yale Food Addiction Scale ............................................... 109

9. Schlussfolgerung und Ausblick ............................................................... 110

Literaturverzeichnis Teil 3 - Diskussion ......................................................... 114

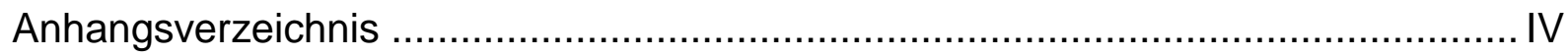




\section{Abbildungsverzeichnis}

- Abbildung 1: YFAS 2.0 'food addiction' by weight class

- Abbildungen 2/3: Aufteilung von ,Food Addiction“ nach Schweregrad/ nach BMI Gruppe (eigene Darstellung)

- Abbildung 4: Zusammenhang zwischen rigider Kontrolle, Heißhungersymptomen, „Food Addiction“ und Essstörungen Abbildung 5: Prävalenz von YFAS 2.0 ,Food Addiction' in drei unterschiedlichen deutschen Stichproben

- Abbildung 6: Postulierter Zusammenhang zwischen persönlichen Verhaltensweisen, Essstörungen und ,Food Addiction“

- Abbildung 7: Die Top 5 Verhaltensweisen der Deutschen mit dem höchsten Genuss

- Abbildung 8: Verhaltensweisen mit dem höchsten Genussempfinden bei Personen mit Übergewicht/Adipositas im Vergleich zu Normalgewichtigen

- Abbildung 9: Offene Nennungen, die als wichtig für genussvolles Essen eingeschätzt wurden.

- Abbildung 10: Selbsteinschätzung der Deutschen als Genießer (6-stufige Skala)

- Abbildung 11: Prävalenz Food Addiction nach BMI-Kategorie in drei deutschen Stichproben

- Abbildung 12: Ausprägung der Symptome in drei deutschen Stichproben (blau $=$ repräsentativ, rot $=$ morbide Adipositas, grün $=$ Sportler $)$

- Abbildung 13: Ausprägung der Symptome in drei deutschen Stichproben NUR von Personen MIT Food Addiction

- Abbildung 14: Postulierter Zusammenhang zwischen rigider Kontrolle, Heißhungerattacken und Food Addiction, sowie Essstörungen

- Abbildung 15: Prävalenz Food Addiction nach BMI-Kategorie und potentielle Überschneidungen mit Essstörungen

- Abbildung 16: Möglicher Zusammenhang zwischen Persönlichkeitseigenschaften, Food Addiction und Essstörungen 


\section{Tabellenverzeichnis}

- Tabelle 1: Diagnosekriterien für Substanzgebrauchsstörungen nach DSM-5

- Tabelle 2: Diagnosekriterien nach DSM-5 mit möglicher Übertragbarkeit auf Essen und der Häufigkeit der Erfüllung in einer repräsentativen deutschen Stichprobe

- Tabelle 3: Demographic characteristics of the sample compared to the German population (18-65 years)

- Tabelle 4: Symptoms, illustrative items* and item count* (number of questions adding up for each of the symptoms) of the YFAS 2.0

- Tabelle 5: Frequencies of endorsed YFAS 2.0 'food addiction' symptoms, by weight class.

- Tabelle 6: Frequencies of endorsed YFAS 2.0 'food addiction' symptoms, by YFAS 2.0 'food addiction' 'diagnostic' categorization

- Tabelle 7: Anthropometrische Daten der Stichprobe $(n=64)$, Prävalenz YFAS 2.0 ,Food Addiction“ und weitere Studienvariablen (eigene Darstellung)

- Tabelle 8: Continuous variables of study population $(n=1025)$

- Tabelle 9: Frequencies of YFAS 2.0 food addiction symptoms fulfilled

- Tabelle 10: Mean values for both categories of perfectionism in three subsamples

- Tabelle 11: Diagnosekriterien nach DSM-5, Beispielitems aus YFAS 2.0 und Häufigkeit der Symptome in verschiedenen deutschen Stichproben

- Tabelle 12: Prävalenz von Food Addiction in drei Stichproben nach Geschlecht

- Tabelle 13: Prävalenz von Food Addiction in drei Stichproben nach Altersgruppen

- Tabelle 14: Prävalenzen Food Addiction und Ausprägung der Symptome in drei deutschen Stichproben

- Tabelle 15: Ausprägung der YFAS-Symptome NUR von Personen mit einer Food Addiction in drei deutschen Stichproben und Symptomausprägungen bei Alkoholabhängigkeit zum Vergleich 


\section{Danksagung}

Mein besonderer Dank geht an meinen Doktorvater, Herrn PD Dr. med. Thomas Ellrott, der mir die Bearbeitung des hochaktuellen Themas Food Addiction ermöglicht, mich bei all meinen Beiträgen immer unterstützt, und besonders die Vorstellung unserer Arbeit auf Konferenzen, Symposien und Tagungen im In- und Ausland befürwortet und gefördert hat. Durch dich habe ich meinen Horizont, meine wissenschaftliche Perspektive und meine Forschungskompetenzen erweitern dürfen und sehr viel Spannendes gelernt. Danke auch an meinen Zweitprüfer, Herrn Professor Dr. Norbert Hagemann und seinem Team, das ich in Bern kennenlernen durfte und mit welchem es einen anregenden und inspirierenden Austausch in Kassel gab. Ich freue mich auf mögliche Kooperationen in der Zukunft. Vielen Dank auch an meinen Drittprüfer, Herrn Dr. Arne Göring, für seine allzeit motivierenden Worte und das Vertrauen in mich als junge Lehrende und Vortragende.

Ganz herzlich danken möchte ich zudem all meinen Co-Autoren für die stundenlangen Telefonate, zahlreichen Mails mit Tipps und Tricks und gegenseitiger Motivation: Melanie Schipfer, Brian Cook, Annegret Weiß, Erica Schulte, Adrian Meule, dem Jungen Netzwerk des Kompetenznetzes Adipositas unter Leitung von Dr. Christina Holzapfel und Dr. Solveig Hansen aus der Medizinethik Göttingen.

Danke an das Team des IfE und der Adipositasambulanz, allen voran Angelika und Catrin, für die angenehme Arbeitsatmosphäre im Institut.

Ein großes Dankeschön an alle Studienteilnehmer ${ }^{1}$, ohne die diese Projekte nicht möglich gewesen wären.

Eine große Bedeutung in meinem Leben haben der Triathlon- und Laufsport mit all meinen Trainingspartnern aus den verschiedensten Vereinen LG Haßberge, LSF Münster, Tri Finish Münster, ASC Göttingen und LG Göttingen. Danke euch für Alles.

Auch wenn nicht alle meine engsten Freunde lokal nahe bei mir sind, so sind sie doch immer in meinem Herzen bei mir. Danke meiner liebevollen Familie, die für mich alles bedeutet und mir alles ermöglich hat. Danke Jasper, dafür, dass du immer für mich da bist.

\footnotetext{
${ }^{1}$ Aus Gründen der Vereinfachung wird in vorliegender Dissertationsschrift ausschließlich die männliche Form verwendet. Personen weiblichen wie männlichen Geschlechts sind darin gleichermaßen eingeschlossen.
} 


\section{Teil 1 - Einleitung}

\section{Einführung}

„Die Hälfte aller Erwachsenen leidet an einer Suchterkrankung" (Sussman, 2017). Diese im Jahr 2017 publizierte Aussage beruht auf Berechnungen eines amerikanischen Psychologen. Demnach leiden bis zu 50 \% der erwachsenen Nordamerikaner und der erwachsenen Europäer innerhalb eines 12-MonatsZeitraums an einer, $23 \%$ sogar an mindestens zwei koexistierenden Suchterkrankungen (Sussman, 2017). Suchterkrankungen gelten damit als bedeutsames weltweites Public-Health-Problem (Whiteford et al., 2013). Bei Suchterkrankungen handelt es sich nicht nur um reine Substanzgebrauchsstörungen mit dem Agens der Droge, sondern auch um nicht-substanzbezogene Verhaltensstörungen, wie das pathologische Glücksspielen (American Psychiatric Association, 2013).

Im Zuge einer Verdreifachung der Prävalenzen von Übergewicht und Adipositas seit 1975, auf einen Anteil von nun 39, beziehungsweise $13 \%$ der erwachsenen Bevölkerung weltweit (World Health Organization (WHO), 2017), wurden ätiologische Faktoren für diese Entwicklungen gesucht. Einen dieser Faktoren könnte ein suchtartiges Essverhalten darstellen (Brownell \& Gold, 2012b).

Basierend auf der Annahme eines essensassoziierten Suchtkonzepts wurden bereits verschiedene Tier- und Humanstudien durchgeführt. Diese zeigen, dass Lebensmittel (verschiedene Substanzen) oder der Prozess des Essens (Verhalten), möglicherweise biologische und psychologische Belohnungsprozesse auf ähnliche Weise triggern können wie dies durch Drogen geschieht (Gearhardt, Corbin, \& Brownell, 2009b; Hebebrand et al., 2014). Von den Autoren wurde dieses Konstrukt „Food Addiction“ benannt (Gearhardt, Corbin, \& Brownell, 2009b), und rückte sowohl in der öffentlichen Diskussion, als auch in der wissenschaftlichen Forschung immer stärker in den Fokus (Meule \& Gearhardt, 2014). So wird das Konzept Food Addiction unter psychometrischen Gesichtspunkten seit dem Jahr 2009 mittels eines Fragebogens, der Yale Food Addiction Scale (YFAS), beforscht (Gearhardt et al., 2009b; Gearhardt, Corbin, \& Brownell, 2016). Aussagekräftige bevölkerungsrepräsentative Studien und Studien in der deutschen Bevölkerung stellten jedoch noch eine Forschungslücke dar. 
Neben den wissenschaftlichen Ansatzpunkten werden Bezeichnungen aus dem Suchtkonzept, wie "Schokoladensucht“ oder „Fresssucht“, zudem häufig in den Medien und in der Alltagssprache genutzt, um das persönliche Essverhalten bei essensassoziierten Problemen zu beschreiben. So ergab eine Internetrecherche mit dem Begriff „Food Addiction“ innerhalb von 0,49 Sekunden knapp 13 Millionen Treffer; eine deutschsprachige Suche mit den Begriffen "Essen“ und "Sucht" sogar 28 Millionen Treffer. Selbsthilfegruppen wie die „Food Addicts Anonymous" bestehen beispielsweise bereits seit den 1980er Jahren (Food Addicts Anonymous, n.d.).

Aufgabe der wissenschaftlich fundierten Forschung ist es nun, diese Populäraussagen zu prüfen und zur weiteren Aufklärung des Konzeptes Food Addiction beizutragen (Brownell \& Gold, 2012b).

In vorliegender Dissertationsschrift wurde deshalb suchtartiges Essverhalten zum ersten Mal weltweit - mittels des Fragebogens YFAS 2.0 in einer bevölkerungsrepräsentativen Stichprobe, der gesamtdeutschen Erwachsenenbevölkerung, untersucht (siehe Teil 2 Eigene Publikationen zu Food Addiction). Die eigenen Ergebnisse zeigen, dass Personen mit morbider Adipositas, sowie Personen mit Untergewicht höhere Prävalenzen von Food Addiction aufweisen als Personen mit Normalgewicht. Rechnet man die gefundenen Prävalenzen in der bevölkerungsrepräsentativen Stichprobe auf die Einwohnerzahl um, erfüllen etwa vier Millionen Deutsche in allen Gewichtskategorien die Kriterien einer Food Addiction. Um potentiell beeinflussende Variablen für eine Food Addiction zu ermitteln, wurden weitere Personengruppen untersucht. So wurden an einer deutschen Universitätsklinik Personen mit morbider Adipositas und in einer Online-Erhebung deutschsprachige Ausdauerathleten befragt. Die Ergebnisse zeigen, dass sowohl beeinflussende Parameter im Essverhalten, wie auch vulnerable Gruppen für Food Addiction vorliegen (Hauck, Weiß, Schulte, Meule, \& Ellrott, 2017a). Unklar ist derzeit noch, ob Food Addiction eine neue Form von Substanzgebrauchsstörungen darstellt, oder eher den Verhaltensstörungen zuzuordnen ist (American Psychiatric Association, 2013; Hebebrand et al., 2014). Weiterhin besteht Forschungsbedarf im Hinblick auf die genaue Definition und Einordnung von Food Addiction (Albayrak, Kliewer, Föcker, Antel, \& Hebebrand, 2015; Meule \& Kübler, 2012; Ziauddeen, Farooqi, \& Fletcher, 2012b), die Abgrenzung, beziehungsweise Überschneidung, von Food Addiction und klassischen Essstörungen (Hauck \& Ellrott, 2017) sowie die 
Nutzbarkeit dieser Erkenntnisse in der Prävention und Therapie von anomalem Essverhalten, respektive Übergewicht und Adipositas. Diese Punkte werden im Diskussionsteil der Dissertationsschrift aufgegriffen.

Die vorliegende kumulative Dissertationsarbeit ist in drei Teile aufgeteilt. In Teil eins, der Einleitung, gibt das einführende Kapitel zunächst einen kurzen Überblick in die Thematik, bevor in Kapitel eins Suchterkrankungen im Allgemeinen definiert, und in Kapitel zwei der Bogen von Suchterkrankungen zu suchtartigem Essverhalten gespannt wird. Den zweiten Teil der Dissertationsschrift bilden die Kapitel 3 bis 7, die - bis auf Kapitel 5 - alle bereits veröffentlicht und publiziert sind. Dieser zweite Dissertationsteil stellt somit die eigenen Publikationen dar. Der dritte und abschließende Teil der Dissertationsarbeit beinhaltet eine gemeinsame Diskussion aller eigenen Ergebnisse und gibt einen Ausblick auf zukünftige Forschungsfelder im Themengebiet der Food Addiction.

\section{Suchterkrankungen Allgemein}

In vorliegender Dissertationsarbeit wurde suchtartiges Essverhalten untersucht. Im ersten Kapitel der Arbeit sollen zunächst einmal Suchterkrankungen allgemein vorgestellt werden, um zu einem Grundverständnis von Suchterkrankungen beizutragen.

\subsection{Definition}

Der deutsche Ausdruck „Sucht“ stammt vom Begriff „siechen“, dem „Leiden an einer Krankheit“ ab (Kunkel-Razum, Gallmann, Kunkel, Münzberg, \& Bibliographisches Institut Mannheim, 2017). Das englische Wort „addiction“ dagegen leitet sich vom lateinischen Wort „addicere" ab und bedeutet „sich einer Sache widmen" (Stevenson \& Pearsall, 2010). Der lateinische Begriff wurde zunächst neutral interpretiert und erlangte erst durch eine Medikalisierung und Bezugnahme zu Substanzen in den letzten zehn Jahren seine heutige negativ geprägte Bedeutung (Finlayson, 2017). Beide Begriffsdarstellungen finden sich in der heutigen Definition von Suchterkrankungen. So definiert das Nationale Institut für Drogenmissbrauch Suchterkrankungen wie folgt: „Addiction is defined as a chronic, relapsing brain disease that is characterized by compulsive drug seeking and use, despite harmful 
consequences" (NIDA, 2014). Eine Suchterkrankung schreitet demnach von Impulsivität zu Zwanghaftigkeit fort und gliedert sich in die drei Phasen „Rausch/Intoxikation“, „Entwöhnung/negative Auswirkung“ und „intensive Beschäftigung/Erwartung“ (Koob \& Le Moal, 1997). Die fünf Elemente von Sucht sind nach Sussman und Sussman (2011): (1) wiederholte Ausführung der Verhaltensweise um angenehme Effekte zu erzielen, (2) Überbeschäftigung mit der Substanz/dem Verhalten, (3) temporäre Befriedigung, (4) Kontrollverlust und (5) Leiden unter negativen Konsequenzen.

Die Vulnerabilität an einer Sucht zu erkranken kann zu 40 bis $60 \%$ durch genetische Faktoren erklärt werden (Kendler, Thornton, \& Pedersen, 2000; Uhl, Liu, \& Naiman, 2002). Daneben gelten Umweltfaktoren, wie Familie und Umfeld, aber auch der Entwicklungs- und Gesundheitszustand einer Person als Einflussfaktoren (NIDA, 2014). Genetische Faktoren und Umweltfaktoren interagieren dabei auf komplexe Weise miteinander (Volkow \& Wise, 2005).

Für eine international gültige und vergleichbare Klassifikation von Erkrankungen werden alle Erkrankungen in der Internationalen Klassifikation der Krankheiten (ICD) und im Diagnostischen und Statistischen Manual Psychischer Störungen (DSM) systematisiert. In der aktuellen zehnten Auflage der ICD (ICD-10; National Center for Health Statistics, 2016) und der fünften Auflage des DSM (DSM5; American Psychiatric Association, 2013), werden auch Suchterkrankungen geführt. Diese finden sich im Themenblock der mentalen Störungen und werden im Folgenden näher beschrieben.

\subsubsection{Suchterkrankungen nach DSM-5}

a. Substanzbezogene Störung

Im Diagnostischen und Statistischen Manual Psychischer Störungen (American Psychiatric Association, 2013) werden „Substanzbezogene und suchtartige Erkrankungen“ als eigenständiges Kapitel geführt. Die zehn darin unterschiedenen Klassen von Drogen sind: Alkohol, Koffein, Cannabis, Halluzinogene (zwei Klassen), Inhalationsmittel, Stimulanzien, Opioide, Tabak und andere nicht spezifizierte Substanzen. Ihnen allen gemeinsam ist eine sehr starke und direkte Aktivierung des Belohnungssystems im Gehirn. 
Substanzbezogene Störungen lassen sich in Substanzgebrauchsstörungen und substanzinduzierte Störungen unterteilen. Substanzinduzierte Störungen beinhalten Intoxikation, Entzugssymptome und weitere substanz- oder medikamenteninduzierte mentale Störungen. Im weiteren Verlauf vorliegender Dissertationsarbeit wird ausschließlich auf Substanzgebrauchsstörungen eingegangen. Substanzgebrauchsstörungen werden durch eine Veränderung im Gehirn charakterisiert, die zu wiederholten Rückfällen und einem starken Verlangen nach der Substanz führt. Insgesamt elf Symptome aus vier Oberkategorien beschreiben dieses Störungsbild spezifischer. Die Oberkategorien sind Kontrollverlust, soziale Beeinträchtigung, riskanter Gebrauch und pharmakologische Kriterien. Der Schweregrad einer Substanzgebrauchsstörung wird durch die Anzahl der erfültten Symptome klassifiziert. So wird bei Vorliegen von zwei oder drei Symptomen von milder Substanzgebrauchsstörung gesprochen. Eine moderate Substanzgebrauchsstörung liegt bei vier bis fünf, und eine schwere bei sechs oder mehr Symptomen vor. Für die Diagnose einer Substanzgebrauchsstörung ist zudem ein klinisch signifikantes Leiden ausschlaggebend. Dies bedeutet, dass die Symptome des DSM bei einer betroffenen Person nicht nur oberflächlich vorliegen, sondern zu schwerwiegenden negativen Konsequenzen in deren Leben führen. Wenn kein klinisch signifikantes Leiden vorliegt, wird niemals die Diagnose einer Substanzgebrauchsstörung gestellt werden, gleich wie viele der anderen elf Symptome erfüllt sind. Insgesamt liegen somit 12 Kriterien für Substanzbezogene Störungen vor. Diese sind in Tabelle 1 aufgelistet (American Psychiatric Association, 2013).

Tabelle 1: Diagnosekriterien für Substanzgebrauchsstörungen nach DSM-5 


\begin{tabular}{|l|}
\hline Diagnosekriterien für Substanzgebrauchsstörungen nach DSM-5* \\
\hline Einnahme größerer Mengen oder länger als geplant (amount) \\
\hline Erfolglose Versuche zur Einschränkung/Kontrolle (attempts) \\
\hline Hoher Zeitaufwand (time spent) \\
\hline Craving \\
\hline Versagen bei Verpflichtungen (obligation) \\
\hline Substanzgebrauch trotz sozialer/persönlicher Probleme (problems) \\
\hline Aufgabe von Aktivitäten (activities given up) \\
\hline Leid (impairment/distress) \\
\hline Substanzgebrauch in gefährlichen Situationen (physically hazardous situations) \\
\hline Substanzgebrauch trotz physischer/emotionaler Konsequenzen (consequences) \\
\hline Toleranzentwicklung (tolerance) \\
\hline Entzugssymptome (withdrawal) \\
\hline
\end{tabular}

*(American Psychiatric Association, 2013)

\section{b. Verhaltenssucht}

Neben den Substanzbezogenen Störungen führt das DSM-5 seit dem Jahr 2013 erstmals auch eine Verhaltenssucht, das pathologische Glücksspielen, mit auf. Die Rechtfertigung für deren Aufnahme basiert auf wissenschaftlichen Nachweisen darüber, dass das pathologische Glücksspiel das Belohnungssystem auf ähnliche Weise aktivieren kann wie Drogen (American Psychiatric Association, 2013). Zudem gleichen die Verhaltenssymptome von Betroffenen denjenigen nach Drogenkonsum. Das Online-Spielen, die Internet-Sucht, die Sexsucht, die Sportsucht und die Kaufsucht werden als potentielle weitere exzessive Verhaltensweisen im DSM-5 benannt, sind aber (noch) nicht inkludiert. Derzeit fehlen noch wissenschaftliche Nachweise zur Etablierung dieser Verhaltensweisen als mentale Störung (American Psychiatric Association, 2013; Potenza, 2014). Aus ähnlichen Gründen sind auch suchtartiges Essverhalten und Adipositas nicht in das DSM-5 inkludiert (American Psychiatric Association, 2013; Volkow, Wang, Tomasi, \& Baler, 2013a). 


\subsubsection{Suchterkrankung nach ICD-10}

Für medizinische Diagnosen ist die ICD (englisch: „International Statistical Classification of Diseases") das weltweit wichtigste anerkannte Klassifikationssystem (National Center for Health Statistics, 2016). Die ICD wird von der WHO herausgegeben. Seit dem 01.Januar 2018 ist in Deutschland die ICD-10-GM Version 2018 gültig. Das fünfte Kapitel der ICD-10 behandelt die psychischen und Verhaltensstörungen. Hierzu zählen auch die Störungen durch psychotrope Substanzen (F10 - F19). Eine aktualisierte elfte Version der ICD (ICD-11) soll im Mai 2018 verabschiedet werden. Durch die Änderungen im Bereich der Verhaltenssüchte von DSM-IV zu DSM-5, werden nun auch Anpassungen von ICD-10 zu ICD-11 diskutiert. Pathologisches Glücksspiel und Störungen im Zusammenhang mit Computer- und Internetspielen sollen nun $\mathrm{zu}$ den psychischen und Verhaltensstörungen der ICD-11 eingruppiert werden. Für zukünftige ICD-Versionen werden die Aufnahmen von Störungen durch die Nutzung sozialer Netzwerke und Störungen im Zusammenhang mit exzessiver Pornographienutzung diskutiert. Ausstehend ist darüber hinaus eine klare Definition, ab wann von schädlicher Nutzung gesprochen wird (National Center for Health Statistics, 2016; Rumpf \& Mann, 2017; World Health Organization (WHO), 2018).

\subsection{Geschichte}

Die Forschung zu suchtartigem Verhalten begann in den 1930er Jahren. Personen die an einer Sucht erkrankten galten zu dieser Zeit als moralisch unterentwickelt und willensschwach. Anstelle von Prävention und Therapie wurden die Betroffenen selbst verantwortlich gemacht. Im Zuge bahnbrechender Forschungsarbeiten seit den 80er Jahren (zum Beispiel: Di Chiara \& Imperato, 1988; Fowler, Volkow, Kassed, \& Chang, 2007) am menschlichen Gehirn, an genetischen, biologischen und Umweltfaktoren wurde das Verständnis von kompulsiver Drogeneinnahme revolutioniert, und die Präventions- und Therapieangebote wurden dahingehend angepasst. Nach heutigem Verständnis beeinflussen Suchterkrankungen sowohl das Gehirn, als auch das Verhalten (NIDA, 2014). 


\subsection{Mechanismen}

Das menschliche Belohnungssystem (mesolimbisches System) ist Teil des limbischen Systems des Gehirns und ermöglicht das Empfinden von Glück und die Wahrnehmung von Emotionen. Damit lebenserhaltende Aktivitäten, wie beispielsweise die Aufnahme von Nahrung oder soziale Interaktionen, regelmäßig vollzogen werden, sind diese mit einer Aktivierung des Belohnungssystems verknüpft. Durch die Erzeugung eines positiven, belohnenden Feedbacks kann die regelmäßige Ausübung dieser Aktivitäten sichergestellt werden. Die Kommunikation innerhalb des Gehirns läuft über Neurone, die ihre Signale über Neurotransmitter übertragen, und so zu einer Weiterleitung von Informationen führen (die Mechanismen werden unter anderem auf den Seiten des National Institute of Drug Abuse erläutert; NIDA, 2014).

Eine Aktivierung des mesolimbischen Systems kann aber auch durch Drogen erfolgen. Bestimmte Drogen vermögen es in die Kommunikationswege zwischen Neuronen einzugreifen, indem sie die chemische Struktur von Neurotransmittern imitieren. So können Drogen an Rezeptoren der Neurone andocken und diese aktivieren. Andere Drogen wiederum veranlassen Neurone dazu, eine erhöhte Anzahl an Neurotransmittern auszustoßen, oder deren Rücknahme zu verhindern, so dass es zu einer verstärkten Aktivierung kommt. Zumeist handelt es sich im mesolimbischen System um den Neurotransmitter Dopamin. Dopamin wirkt direkt auf das Belohnungssystem des Gehirns. Eine erhöhte Verfügbarkeit von Dopamin, beispielsweise durch Drogenkonsum, kann zu euphorischem Empfinden führen. Drogenkonsumenten zeigen demnach ein starkes Streben nach Wiederholung des euphorischen Gefühls. Bei einem Vergleich von Drogen und natürlichen Belohnungsreizen wirken letztgenannte weniger stark euphorisierend, so dass bei Drogenkonsum dieser favorisiert wird. Dies könnte einen der Gründe dafür darstellen, dass Drogenkonsumenten in Abstinenzzeiten an Depressionen leiden (NIDA, 2014). Opioidpeptide, wie Enkephaline oder Endorphine, können die dopaminerge Erregungsleitung manipulieren (Feng et al., 2012). Cannabinoide können die Rezeptorfunktion beeinflussen (Mechoulam \& Parker, 2013).

Wie bereits erwähnt besteht der Kreislauf der Sucht aus den drei Phasen „Rausch/Intoxikation“, „Entwöhnung/negative Auswirkung“ und „intensive Beschäftigung/Erwartung“ oder Craving. Alle drei Phasen beeinflussen sich 
gegenseitig und finden primär in den Gehirnregionen Basalganglien, erweiterte Amygdala und präfrontaler Cortex statt (Koob \& Le Moal, 1997).

Die erste Phase „Rausch/Intoxikation“ beschreibt den Konsum der Substanz und die Wahrnehmung deren belohnender und berauschender Wirkung. Diese Wirkung wird durch die Ausschüttung von natürlichen Opioiden und dem Neurotransmitter Dopamin hervorgerufen (Koob \& Le Moal, 1997). Schlüsselreize für den Konsum einer Substanz stellen exterozeptive Signale, wie Aussehen und Geruch, und interozeptive Signale, beispielsweise die persönliche Stimmung, dar (Mason \& Higley, 2012). Das individuelle Reaktionsmuster auf bestimmte Schlüsselreize kann bei Therapien sogar den Behandlungserfolg vorhersagen (Cooney, Litt, Morse, Bauer, \& Gaupp, 1997). Mason und Kollegen entwickelten hierzu das "cue reactivity model" (Mason, Light, Escher, \& Drobes, 2008). Dieses Modell berücksichtigt alle Faktoren (Dosis, Auslösereize, Stress) die zu starkem Verlangen/Craving führen (Mason \& Higley, 2012). Durch chronischen Substanzgebrauch kann es zu Veränderungen in den Basalganglien kommen, so dass eine natürliche Belohnungswirkung nicht mehr den erwünschten Effekt erzielt (Koob \& Le Moal, 1997). Impulsivität spielt in dieser ersten Phase „Rausch/Intoxikation“ eine bedeutsame Rolle. So trägt Impulsivität zu einer erhöhten Wahrscheinlichkeit initialer Drogeneinnahme bei, und scheint bei erkrankten Individuen Rückfälle zu provozieren. Weiterhin konnte de Wit zeigen, dass Drogenmissbrauch zu einem Verlust der Hemmungen führen kann, was ein Zeichen für beeinträchtigte Impulskontrolle darstellt (de Wit, 2009).

In der zweiten Phase, der „Entwöhnung/negativen Auswirkung“, wird die Substanz weiter konsumiert, da zum Einen die natürlichen Belohnungswirkungen reduziert sind, das heißt, nur noch die Droge den erwünschten berauschenden Effekt erzielen kann, und zum Anderen die Stressmechanismen im Gehirn aktiviert werden. Im Gehirnbereich der erweiterten Amygdala kommt es bei Fehlen der Substanz zu einer Ausschüttung von Neurotransmittern, die Angst, Stress, Ruhelosigkeit und negative Stimmung verursachen können. Hier zeigt sich die doppelt negative Wirkung von Drogen: zum einen erzielt die Substanz nicht mehr dieselbe erhoffte positive emotionale Wirkung und löst zum anderen zusätzlich negative Gefühle aus (Koob \& Le Moal, 1997). In dieser Phase verschiebt sich das Verhalten von Impulsivität hin zu Zwanghaftigkeit (Mason \& Higley, 2012). 
Die dritte Phase „intensive Beschäftigung/Erwartung/Craving“ spielt sich im präfrontalen Cortex ab. Die Phase beschreibt die Wiederaufnahme des Suchtverhaltens nach Abstinenz (Koob \& Le Moal, 1997). Im präfrontalen Cortex werden die exekutiven Funktionen, wie Gedächtnis, Handlungssteuerung und emotionale Bewertung, kontrolliert. Die Ausreifung des präfrontalen Cortexes findet in der Adoleszenz statt. Die Handlungssteuerung und -bewertung ist daher in den Jugendjahren noch nicht vollständig ausgereift (NIDA, 2014). Da der Beginn eines Austestens von Drogen, wie zum Beispiel Alkohol, jedoch zumeist auch in die Adoleszenz fällt (Wagner, 2002), können schwerwiegende Veränderungen im Präfrontalen Cortex und veränderte Neuroadaptionen mit lebenslangen negativen Konsequenzen resultieren (Davis \& Claridge, 1998). Auch die Impulsivität einer Person wird hier gesteuert. Bei drogenabhängigen Personen ist die Impulskontrolle gestört und es kann so zu spontanen, unreflektierten Handlungen kommen (Koob \& Le Moal, 1997). Bei einer manifesten Drogenabhängigkeit werden eine Vielzahl von Gehirnregionen und Schaltkreisen beeinträchtigt. So zeigen sich beispielsweise Rückgänge in der Verfügbarkeit von Dopamin-D2-Rezeptoren bei akutem Entzug, erhöhte Aktivitäten der Stresssysteme im Gehirn, sowie neuronale Anomalitäten (George F. Koob, 2012).

\subsection{Protektoren und Risikofaktoren}

Eine Reihe von Protektoren und Risikofaktoren für Suchterkrankungen können bereits in frühen Lebensjahren detektiert werden. Als Protektoren gelten gute Selbstkontrolle, elterliche Zuneigung, Freundschaften, Fähigkeiten und Fertigkeiten sowie schulische Anti-Drogen-Programme (NIDA, 2014). Dagegen zählen aggressives Verhalten in der Kindheit, mangelnde elterliche Zuwendung, geringe Sozialkompetenzen und die Verfügbarkeit von Drogen (NIDA, 2014), sowie Stress, Misshandlungen in der Kindheit, Traumata und negativ geprägte Emotionalität (Nemeroff, 1996) zu den Risikofaktoren. Besonders gefährdet für einen Einstieg in den Drogenkonsum scheint die Altersgruppe zwischen 14 und 20 Jahren zu sein (Center for Behavioral Health Statistics and Quality., 2015; McCabe, West, Morales, Cranford, \& Boyd, 2007; Substance Abuse and Mental Health Services Administration, 2013). 


\subsection{Konsequenzen des Substanzgebrauchs}

Durch regelmäßigen und chronischen Substanzgebrauch kann es zu Veränderungen der mentalen Verfassung, wie gesteigerter Angst, negativer Emotionalität, Veränderungen von Schlafphasen und Essverhalten, aggressivem Verhalten und zu Veränderungen in Aufmerksamkeit, Konzentration und Gedächtnisleistung, kommen (Sinha et al., 2007). Als langfristige Risiken gelten die Entwicklung einer Abhängigkeit, eine dauerhafte kognitive Beeinträchtigung und ein erhöhtes Risiko für schizophrene Psychosen (Schneider, 2004). Co-existent zu Suchterkrankungen lassen sich häufig mentale Erkrankungen und medizinische Probleme diagnostizieren. Das Risiko für eine psychiatrische Erkrankung steigt bei Vorliegen einer Suchterkrankung, ebenso vice versa (Greenfield \& Crisafulli, 2012). Neben den gesundheitsschädlichen Konsequenzen für die eigene Person können auch Mitmenschen gefährdet werden. Besonders gefährdet sind hier Ungeborene im Mutterleib. Aber auch Passivrauchen und die Ausbreitung infektiöser Krankheiten, zum Beispiel über verunreinigte Spritzen, zählen zu den Gefahren für Mitmenschen (NIDA, 2014).

\section{Suchtartiges Essverhalten/Food Addiction}

Ein mögliches suchtartiges Potential wurde - neben den in Kapitel eins benannten etablierten Substanzen - in den letzten Jahren auch dem Konsum von Lebensmitteln zugesprochen. Postuliert wurde dabei, dass vor allem energiedichte, fett- und zuckerreiche Lebensmittel zu einer potentiellen Food Addiction führen können. Dabei wurde auch angenommen, dass Food Addiction einen Beitrag zur Erklärung des Anstiegs der Adipositasprävalenz leisten könnten (Gearhardt, 2012). Im folgenden Kapitel soll das Konzept "suchtartiges Essverhalten/Food Addiction“ kurz vorgestellt werden, da dieses die Grundlage vorliegender eigener Forschungsarbeiten, und damit der kumulativen Dissertationsschrift, bildet.

\subsection{Definition}

Das Food Addiction-Konzept basiert auf zwei Annahmen: 
Zum einen, dass, im Sinne einer Substanzgebrauchsstörung, bestimmte hochprozessierte zucker- und fettreiche Lebensmittel mit hoher Energiedichte spezifische biochemische oder physiologische Eigenschaften besitzen, die analog zu Drogen wirken können (Gold, Frost-Pineda, \& Jacobs, 2003). Hierzu müssen diese Lebensmittel inhärente suchterzeugende Inhaltsstoffe oder Eigenschaften besitzen, die sowohl die kognitiven Kontrollmechanismen einer Person, als auch deren homöostatische Mechanismen untergraben können. Verarbeitete Lebensmittel werden von den Herstellern dahingehend entwickelt, dass sie Geschmack und Befriedigung maximieren (Hebebrand et al., 2014). Zudem sollen diese Lebensmittel über Geschmack, Aroma, Geruch, Textur und sogar Klang alle Sinne anregen (Spence, 2012). In der heutigen modernen Gesellschaft übernimmt Nahrung demnach nicht mehr nur noch die Funktion der Energieaufnahme zur Überlebenssicherung, sondern teilweise auch die Vermittlung eines Belohnungsgefühls, die Kompensation von Stress oder Müdigkeit und die Verbesserung der Stimmung (Ahmed, Avena, Berridge, Gearhardt, \& Guillem, 2013; Canetti, Bachar, \& Berry, 2002). Hochverarbeitete, energiedichte Lebensmittel könnten so einen potentiellen Risikofaktor für pathologisches Essverhalten darstellen. Der Überkonsum dieser Lebensmittel wird als „Food Addiction“ bezeichnet, wenn er die entsprechenden Diagnosekriterien erfüllt (Gearhardt et al., 2009b).

Die zweite Annahme des Food Addiction-Konzepts besagt, dass bestimmte Personen anfällig für den Missbrauch von Lebensmitteln - in erheblichem Umfang und mit klinischer Beeinträchtigung - sind. Diese vulnerablen Personen gleichen in ihren Verhaltensweisen den Verhaltensweisen von Betroffenen einer Suchterkrankung (Finlayson, 2017). So ist bei diesen Personen der Kontrollverlust bei der Aufnahme von Lebensmitteln und der Konsum trotz negativer Gesundheitskonsequenzen charakteristisch (Ahmed et al., 2013; Kleiner et al., 2004).

\subsection{Geschichte/Hintergrund}

Seit Beginn der Existenz von heterotrophen Organsimen wie den Menschen, stellen Nahrungsmittel eine existenzielle Überlebensquelle dar. Ahmed und Kollegen 
propagierten daher, dass Menschen von Nahrungsmitteln abhängig seien, da sie ohne Nahrung nicht überleben können (Ahmed et al., 2013). Die Übertragung des Suchtkonzeptes auf Lebensmittel ist ein sehr komplexes Unterfangen, denn Säugetiere wie der Mensch sind, neben Nahrung, auch auf Wasser und Luft angewiesen und wären daher auch „süchtig“ nach diesen. Dennoch überkonsumieren Menschen weder Wasser noch Luft, einige Menschen möglicherweise jedoch Lebensmittel. Das ist der Grund warum die Forschung am suchtartigen Potential von Nahrung so bedeutsam ist. Denn es ergibt sich das Paradoxon, dass das Überleben ohne Essen nicht möglich ist, bei zu hohem Konsum jedoch eine mögliche Abhängigkeit entstehen kann (Brownell \& Gold, 2012b).

Der biologische Imperativ leitete den Menschen seit jeher dazu, so viel und so kalorienreich wie möglich zu essen, um das Überleben zu sichern. Im Zeitalter der Industrialisierung ergab sich erstmals in der Geschichte der Menschheit eine Situation des Überangebotes an Nahrungskalorien. Im Zuge von industrieller Lebensmittelproduktion und der Entwicklung hochverarbeiteter energiedichter Lebensmittel mit parallelem Rückgang der körperlichen Aktivität, resultierten schließlich Überessen und damit assoziierte Erkrankungen. Personen die sich selbst als suchtkrank bezeichneten, berichten Leidensgefühle bei Nichtvorhandensein von bestimmten Lebensmitteln, starkes Verlangen nach diesen Lebensmitteln und exzessives Überessen (Ahmed et al., 2013).

Ein suchterzeugendes Potential, beispielsweise von Schokolade, wurde bereits 1890 vermutet (Weiner \& White, 2007). Im Jahr 1923 propagierte Sigmund Freud in seinem Buch "Das Ich und das Es“ (Freud, 2017), dass Störungen in der oralen Phase der menschlichen Entwicklung zu späteren suchtartigen Verhaltensweisen (mit oraler Aufnahme der Substanz) führen könnten (Freud, 2017). Erstmalige Erwähnung fand der Begriff „Food Addiction“ im Jahr 1956 durch Randolph (Randolph, 1956). Im Zuge steigender Adipositaszahlen wurde das suchtartige Essverhalten in den Anfängen des 21. Jahrhunderts wieder herangezogen und als potentieller Erklärungsansatz für die Thematik diskutiert (Brownell \& Gold, 2012a; Cota, Tschöp, Horvath, \& Levine, 2006; Gearhardt et al., 2009b). Im Jahr 2007 wurde die "Yale Conference on Food and Addictions" mit rund 40 Experten an der Universität in Yale abgehalten (Brownell \& Gold, 2012a). 
Wissenschaftliche Hinweise auf die Existenz einer potentiellen Food Addiction werden seit den 2000er Jahren durch Studien an Ratten geliefert (Avena, Bocarsly, Rada, Kim, \& Hoebel, 2008; Avena, Long, \& Hoebel, 2005; Avena, Rada, \& Hoebel, 2008a; Hoebel, Avena, Bocarsly, \& Rada, 2009; Hoebel, Rada, Mark, \& Pothos, 1999; Johnson \& Kenny, 2010; Rada, Avena, \& Hoebel, 2005). Fortschritte in den Neurowissenschaften konnten die Bedeutung des Belohnungssystems für das menschliche Essverhalten herausstellen (Stice, Figlewicz, Gosnell, Levine, \& Pratt, 2013; Ziauddeen, Alonso-Alonso, Hill, Kelley, \& Khan, 2015). Neuroanatomische und funktionelle Bildgebungsverfahren trugen zu neuen Erkenntnissen, speziell im Bereich der Dopaminrezeptoren, bei (Schienle, Schäfer, Hermann, \& Vaitl, 2009; Wang et al., 2001). Über bildgebende Verfahren wurden vergleichbare Veränderungen im Belohnungszentrum des Gehirns, sowohl bei Personen mit chronischem Überkonsum an Nahrungsmitteln, als auch bei chronischem Drogenkonsum und einer vorliegenden Adipositas entdeckt (Ahmed et al., 2013). Auch die „Zuckersucht“ (Avena, Rada, \& Hoebel, 2008b) und die „Schokoladensucht“ (Tuomisto et al., 1999; Tuomisto, Lappalainen, Heterington, Morris, \& Tuomisto, 1997) wurden wissenschaftlich untersucht. Gleichzeitig wuchs die wissenschaftliche Evidenz, dass im Gehirn bei Substanzgebrauch und bei Lebensmittelverzehr (Davis et al., 2008; Gearhardt, 2011; Pelchat, Johnson, Chan, Valdez, \& Ragland, 2004) ähnliche Mechanismen ablaufen. Daraufhin wurde ein suchtartiges Potential von Lebensmitteln und insbesondere von hochverarbeiteten energiedichten Lebensmitteln propagiert (Gearhardt, Davis, Kuschner, \& Brownell, 2011). Brownell und Gold wagten darüber hinaus die Hypothese, dass die natürlicherweise nicht vorkommenden, hochprozessierten Lebensmittel ähnliche Wirkweisen wie Kokablätter haben könnten. So entfalten Kokablätter ihr volles Suchtpotential erst in verarbeiteter Form, als sogenanntes Kokain. Natürliche Lebensmittel die erst durch ihre hohe Verarbeitung zu hochkalorischen, fett- und zuckerreichen Produkten verarbeitet werden, könnten ähnliche Wirkweisen besitzen (Brownell \& Gold, 2012a).

Für die Erforschung suchtartigen Essverhaltens in größeren Humanstudien fehlten jedoch weiterhin die Instrumente (Gearhardt et al., 2009b). Erst im Jahr 2009 wurde von Gearhardt und Kollegen ein psychometrisches Instrument (Fragebogen) entwickelt (Gearhardt et al., 2009b). Dieses soll im folgenden Kapitel kurz vorgestellt werden, da es das primäre Erhebungsinstrument der eigenen Studien für die Dissertationsschrift darstellt. 
2.3 Diagnostische Kriterien für Substanzgebrauchsstörungen und Zusammenhänge zum Essverhalten

Um Food Addiction erfassbar und messbar zu machen, wurden die diagnostischen Kriterien für Substanzgebrauchsstörungen (siehe Tabelle 1) nach DSM-IV (American Psychiatric Association, 1998) auf das Essverhalten übertragen, und im Jahr 2009 in Form eines psychometrisch validierten Fragebogens publiziert, der Yale Food Addiction Scale (YFAS; Gearhardt et al., 2009b). Dieser Fragebogen stellt ein „sound tool for identifying eating patterns that are similar to behaviors seen in classic areas of addiction“ (Gearhardt et al., 2009b) dar. Mit Erscheinen einer neuen, fünften, Version des DSM im Jahr 2013 (DSM-5; American Psychiatric Association, 2013), wurde auch die YFAS adaptiert und erschien im Jahr 2016 als YFAS 2.0 (Gearhardt et al., 2016). Die YFAS 2.0 wurde in verschiedene Sprachen übersetzt und ist seit 2016 auch auf Deutsch verfügbar (Meule, Müller, Gearhardt, \& Blechert, 2016). Die Übertragbarkeit der Kriterien für Substanzgebrauchsstörungen auf das Essverhalten wird noch diskutiert. Die meisten Kriterien sind in ihrer Anwendbarkeit auf das Essverhalten jedoch bereits empirisch gestützt oder gelten zumindest als plausibel (Meule, 2015). Tabelle 2 zeigt die Diagnosekriterien nach DSM-5 und deren mögliche Übertragbarkeit auf das Essverhalten. Um die Häufigkeit der Ausprägung einzelner Symptome einschätzen zu können, sind Daten zu Food Addiction aus einer repräsentativen deutschen Stichprobe mit aufgeführt (Hauck et al., 2017a).

Tabelle 2: Diagnosekriterien nach DSM-5 mit möglicher Übertragbarkeit auf Essen und der Häufigkeit der Erfüllung in einer repräsentativen deutschen Stichprobe

\begin{tabular}{|l|l|l|}
\hline Diagnosekriterien nach DSM-5 & $\begin{array}{l}\text { Mögliche } \\
\text { Übertragbar-keit } \\
\text { auf Essen }\end{array}$ & $\begin{array}{l}\text { Häufigkeit in einer } \\
\text { repräsentativen }^{1} \\
\text { Stichprobe }^{3}(\%)\end{array}$ \\
\hline 1. Einnahme größerer Mengen oder länger als & empirisch & 19,2 \\
\hline
\end{tabular}




\begin{tabular}{|c|c|c|}
\hline geplant (amount) & gestützt & \\
\hline $\begin{array}{l}\text { 2. Erfolglose Versuche zur } \\
\text { Einschränkung/Kontrolle (attempts) }\end{array}$ & $\begin{array}{l}\text { empirisch } \\
\text { gestützt }\end{array}$ & 15,6 \\
\hline 3. Hoher Zeitaufwand (time spent) & plausibel & 11,6 \\
\hline 4. Craving & $\begin{array}{l}\text { empirisch } \\
\text { gestützt }\end{array}$ & 11,0 \\
\hline 5. Versagen bei Verpflichtungen (obligation) & plausibel & 17,3 \\
\hline $\begin{array}{l}\text { 6. Substanzgebrauch trotz sozialer/persönlicher } \\
\text { Probleme (problems) }\end{array}$ & plausibel & 18,3 \\
\hline 7. Aufgabe von Aktivitäten (activities given up) & plausibel & 18,9 \\
\hline 8. Leid (impairment/distress) & plausibel & 8,5 \\
\hline $\begin{array}{l}\text { 9. Substanzgebrauch in gefährlichen Situationen } \\
\text { (physically hazardous situations) }\end{array}$ & $\begin{array}{l}\text { wahrscheinlich } \\
\text { weniger relevant }\end{array}$ & 18,3 \\
\hline $\begin{array}{l}\text { 10. Substanzgebrauch trotz } \\
\text { physischer/emotionaler Konsequenzen } \\
\text { (consequences) }\end{array}$ & $\begin{array}{l}\text { empirisch } \\
\text { gestützt }\end{array}$ & 12,7 \\
\hline 11. Toleranzentwicklung (tolerance) & plausibel & 7,4 \\
\hline 12. Entzugssymptome (withdrawal) & $\begin{array}{l}\text { schwer von } \\
\text { einem } \\
\text { Energiedefizit } \\
\text { abgrenzbar }\end{array}$ & 18,5 \\
\hline
\end{tabular}

${ }^{1}$ (American Psychiatric Association, 2013), ${ }^{2}$ (Meule, 2015), ${ }^{3}$ (Hauck et al., 2017a)

Das erstgenannte Kriterium ist der Kontrollverlust (1). Dieser ist definiert als ein Substanzgebrauch in größeren Mengen oder über einen längeren Zeitraum hinweg als ursprünglich vorgesehen. Der Substanzgebrauch geschieht meist heimlich und geht mit einem subjektiven Gefühl des Kontrollverlustes einher. Kontrollverlust spielt nicht nur bei Substanzgebrauchsstörungen, sondern auch bei Essstörungen eine entscheidende Rolle, wie Studien an Personen mit Binge-Eating Disorder (BED) oder Bulimia Nervosa (BN) zeigen (Mitchell, Pyle, \& Eckert, 1981; Vanderlinden, Dalle Grave, Vandereycken, \& Noorduin, 2001).

Wiederholte Fehlversuche den Konsum zu reduzieren oder zu stoppen (2) stellen ein weiteres Symptom dar. Gerade bei Versuchen das Essen einzuschränken, und/oder die Kalorienaufnahme zu reduzieren, können chronische Rückfälle eintreten. In einer repräsentativen Erhebung gab rund ein Drittel der Deutschen an, die Kalorienaufnahme mittels Diäten reduzieren zu wollen, was auf die hohe 
Relevanz des Kriteriums schließen lässt. Als problematisch kann angesehen werden, dass das Körpergewicht bei 60 \% der Befragten nach einer Diät wieder anstieg (Laboga \& Techniker Krankenkasse, 2013).

Für die Diagnose einer Substanzgebrauchsstörung wird zudem die Rolle der Substanz im Alltagsleben der Betroffenen berücksichtigt. Besonders die Zeit, die aufgewendet wird, um die Substanz zu beschaffen, zu konsumieren oder sich von deren negativen Auswirkungen zu erholen (3), steht hier im Fokus. Wie bei Entzugssymptomen auch, spielt dieses Symptom bei verschiedenen Substanzen eine unterschiedlich wichtige Rolle. So ist Essen legal, günstig, einfach zugänglich und sozial akzeptiert, wie auch Nikotin. Bei illegalen Drogen kann dieses Symptom ganz andere Auswirkungen haben. Dennoch berichten von einer Food Addiction Betroffene von hohem Zeitaufwand für Konsum, Beschaffung und Erholung von negativen Gemütszuständen nach exzessivem Nahrungsmittelkonsum.

Das siebte Kriterium stellt die Aufgabe anderer Aktivitäten, wie Zeit mit der Familie und Freunden zu verbringen (7) dar. Personen mit einer Food Addiction berichten von Vermeidung professioneller oder sozialer Situationen, um in diesen Situation nicht zu überessen.

Auch der fortgeführte Konsum einer Substanz trotz physischer oder psychischer Probleme (10) spielt beim Essen eine bedeutsame Rolle. Gerade bei chronischem exzessivem Konsum kalorienreicher Lebensmittel kann es zu schwerwiegenden Gesundheitsproblemen wie Diabetes, Krebs und Herzerkrankungen kommen (Mensink et al., 2013). Adipositas ist zudem assoziiert mit Depression, Angstzuständen, gewichtsbezogener Diskriminierung und Stigmatisierung (Marcus \& Wildes, 2009; Puhl \& Brownell, 2006). Aus diesem Grund muss exzessiver Nahrungsmittelkonsum im klinischen Setting besondere Beachtung finden.

Das Kriterium Toleranzentwicklung (11) bedeutet, dass der gewünschte Effekt nur durch die Aufnahme einer sich ständig erhöhenden Menge der Substanz erreicht wird. Das Kriterium Entzugssymptome (12) beinhaltet physiologische oder kognitive Symptome, die nach Abstinenzperioden auftreten. Beide Kriterien waren nach DSMIV-TR (American Psychiatric Association \& American Psychiatric Association, 2009) nicht für die Diagnose einer Substanzgebrauchsstörung erforderlich. Auch bei Koffein 
ist die Relevanz dieser beiden Kriterien fraglich, denn durch Koffeinaufnahme können Toleranz- und Entzugssymptome hervorgerufen werden, jedoch entsteht dadurch kein klinisch signifikantes Leiden. In Zusammenhang mit Essen existieren zu beiden Kriterien derzeit noch wenige wissenschaftliche Studien, daher stell die Relevanz der Kriterien für Food Addiction zukünftiges Forschungspotential dar (Gearhardt \& Corbin, 2012).

In der Übertragung der Diagnosekriterien einer Substanzgebrauchsstörung auf Lebensmittel beziehungsweise das Essverhalten, ist jedoch zu berücksichtigen, dass es sich bei Lebensmitteln nicht, wie bislang im DSM-5 üblich, um definierte Monosubstanzen handelt, sondern um sehr variable Substanzgemische mit unterschiedlichen Gehalten an Energie, Fetten, Kohlenhydraten, Zuckerarten, Salzen, Aromastoffen, Geschmacksverstärkern und anderen.

In der aktuellen neuen Version, dem DSM-5, sind im Vergleich zur Vorversion, noch die Kriterien Craving, das starke Verlangen die Substanz zu konsumieren (4), wiederholter Substanzgebrauch der zu einem Versagen bei der Erfüllung wichtiger Verpflichtungen führt (5), fortgesetzter Substanzgebrauch trotz sozialer oder zwischenmenschlicher Probleme (6) und wiederholter Substanzgebrauch in gefährlichen Situationen (9) (Gearhardt et al., 2016; Meule et al., 2016) aufgeführt.

Das Kriterium "Craving" (4) ist in seiner Anwendbarkeit auf das Essverhalten empirisch gestützt. So überlappt die Aktivierung neuronaler Strukturen bei verschiedenen Substanzen und Nahrungsmitteln stark (Tang, Fellows, Small, \& Dagher, 2012). Kritisch wird angemerkt, dass der Begriff des Craving von der Industrie auch in deren Marketing eingesetzt wird: So bewarb McDonalds in der Vergangenheit einen Burger unreflektiert mit dem Slogan „crafted for your craving“ (Brownell \& Gold, 2012a). Das nächstbenannte Kriterium „Versagen bei Verpflichtungen" (5) stellt bei suchtartigem Essverhalten vermutlich keinen essentiellen Aspekt dar, da durch Nahrungsmittel keine Intoxikationen provoziert werden (Meule, 2015). „Soziale/persönliche Probleme“ (6), wie soziale Isolation, sind hingegen eindeutig mit einem Überkonsum an Nahrung assoziiert (Meule, 2015). Ein „Konsum in gefährlichen Situationen“ (9) ist beim Essen jedoch weniger relevant. Eine denkbare Gefahrensituation wäre zum Beispiel die Fokussierung auf das Essen statt auf die Umgebung bei einer aktiven Teilnahme am Straßenverkehr. 
Die Diagnose einer Food Addiction bedarf der Erfüllung von mindestens zwei der oben beschriebenen Kriterien innerhalb eines 12-Monats-Zeitraums, plus das Vorliegen klinisch signifikanten Leidens (8).

\subsection{Mechanismen}

Sowohl der Verzehr von Nahrung, als auch die Einnahme von Drogen, werden über das mesolimbische Dopaminsystem gesteuert (siehe Kapitel 1.3; NIDA, 2014). In vorliegendem Abschnitt soll dieses, nun mit Bezugnahme zum Essverhalten, kurz beschrieben werden. Zwar erfolgt die Steuerung der Drogeneinnahme und derjenigen von Lebensmitteln über dasselbe System, jedoch auf unterschiedliche Weise (Wise \& Rompre, 1989). Das Essen aktiviert das Belohnungssystem indirekt über endogene Opioide (Olszewski, Alsiö, Schiöth, \& Levine, 2011), Cannabinoide oder Peptide wie Insulin und Leptin (Abizaid, Gao, \& Horvath, 2006). Drogen können diese Schaltkreise hingegen direkt - über ihre pharmakologischen Effekte aktivieren (Hyman, Malenka, \& Nestler, 2006). Dopaminerge Mechanismen scheinen die Vorfreude und den Ansporn für die Nahrungsaufnahme, Opioide dagegen den aktiven Konsum und die hedonische Bewertung der Nahrung zu bewirken (Barbano \& Cador, 2007). Eine wiederholte Stimulation der Belohnungsmechanismen kann die Konditionierung auf bestimmte Substanzen triggern, und so zu neurobiologischen Anpassungen im Gehirn führen (Volkow \& Wise, 2005). Entsprechende Anpassungen konnten vor allem im Tierexperiment auch durch Lebensmittel mit hohem Fett- und/oder Zuckergehalt hervorgerufen werden (Volkow \& O’Brien, 2007). Kontrollverlust über den Konsum der Lebensmittel und zwanghaftes Verlangen nach den Lebensmitteln können mögliche unerwünschte Folgen darstellen (Volkow \& Wise, 2005).

Studien mit Bezug zu Essverhalten oder Essstörungen zeigen, dass Stimulantien wie Kokain und Metamphetamin den Appetit mittels Übersättigung des Belohnungszentrums unterdrücken können. Neuroleptika (= Dopamin-D2-RezeptorAntagonisten) können das Belohnungssystem teilweise blockieren und somit das Risiko für Adipositas steigern (Volkow \& O’Brien, 2007). Eine Blockierung des Rewardsystems durch Opioid-Rezeptor-Blocker, wie Naltrexon, resultiert bei Personen mit einer Binge-Eating-Störung in einer Reduktion des Konsums an 
hochverarbeiteten süßen, fettreichen Lebensmitteln (Drewnowski, Krahn, Demitrack, Nairn, \& Gosnell, 1995).

Des Weiteren sollen die neuronalen Schaltkreise, durch welche das Ernährungsverhalten vermittelt wird, erwähnt werden. Diese Schaltkreise stellen die Schnittstelle zwischen homöostatisch und hedonisch motivierter Nahrungsaufnahme dar. Homöostatisch bedingte Nahrungsaufnahme findet bei entleerten Energiespeichern oder erhöhtem Energiebedarf statt. In der heutigen modernen Welt findet jedoch auch zunehmend nicht physiologisch, sondern hedonisch (vermittelt zum Beispiel durch Emotionen oder Lernprozesse) bedingte Nahrungsaufnahme statt. Die hedonisch motivierte Nahrungsaufnahme kann die natürliche Energieregulation außer Kraft setzen (Wang, Volkow, Thanos, \& Fowler, 2009). Sie steht zudem im Verdacht suchtartigen Charakter zu vermitteln, da es sich dabei nicht um eine überlebenswichtige, sondern um eine - zunächst - freiwillige Aufnahme von Lebensmitteln handelt (Berthoud, 2011). Die beiden Unterkomponenten der hedonischen Nahrungsaufnahme sind Liking, die hedonische Lust/das Mögen und Wanting, das hedonische Verlangen/Wollen. Besonders das Wanting wird im Kontext von Essstörungen diskutiert, und könnten auch bei Food Addiction eine Rolle spielen (Finlayson, 2017).

\subsection{Risikofaktoren}

Nicht alle Personen mit Zugang zu Drogen werden süchtig nach diesen. Genauso wenig wie Personen mit Zugang zu hochprozessierten Lebensmitteln alle abhängig von diesen werden. Möglicherweise stellt das Lebensalter beim Erstkonsum der hochprozessierten Lebensmittel einen entscheidenden Risikofaktor - ähnlich dem Alter bei Erstkonsum von Drogen - dar (Brownell \& Gold, 2012a). Risikogruppen für pathologisches Essverhalten stellen zudem ethische Minderheiten, Personen mit niedrigem sozioökonomischen Status und geringem Bildungsniveau dar (Kumanyika, 2012).

\subsection{Ergebnisse aus Studien zu suchtartigem Essverhalten, gemessen mittels YFAS} Vorliegende kumulative Dissertationsarbeit besteht aus eigenen Studien zu suchtartigem Essverhalten. Diese wurden mittels YFAS 2.0 erhoben. In vorliegendem Kapitel sollen zunächst exemplarisch Studien anderer Forschergruppen aufgeführt 
werden, um einen kurzen Überblick zum aktuellen Stand der Forschung mit der YFAS 1.0 und der YFAS 2.0 zu geben.

Die erste systematische Übersichtsarbeit zu Studien mit der YFAS 1.0 zeigte eine durchschnittliche Food Addiction-Prävalenz von 19,9 \%. Höhere Werte wurden hierin bei Personen über 35 Jahren, bei Frauen, bei Personen mit Übergewicht/Adipositas und in klinischen, im Vergleich zu nicht-klinischen, Stichproben gefunden. Eingeschlossen wurden 25 Studien mit knapp 200‘000 Teilnehmern, wobei es sich überwiegend um Frauen und Personen mit Übergewicht/Adipositas handelte (Pursey, Stanwell, Gearhardt, Collins, \& Burrows, 2014). Die weltweit erste repräsentative Studie mit der YFAS 2.0 wurde im Rahmen vorliegender Dissertationsarbeit durchgeführt und wird in Kapitel 3 vorgestellt. Die zweite repräsentative Studie wurde knapp ein Jahr später in den USA realisiert und konnte eine Food Addiction-Prävalenz von $15 \%$ ermitteln (m-YFAS 2.0; Schulte \& Gearhardt, 2017). Die Werte waren höher bei jüngeren Personen, Hispanoamerikanern, höherem Jahreseinkommen und Untergewicht oder Adipositas (Schulte \& Gearhardt, 2017). In einer anonymen Onlinebefragung der brasilianischen Bevölkerung wurde eine Prävalenzen von 4,3 \% ermittelt, wobei Frauen stärker von Food Addiction betroffen waren. Food Addiction war mit depressiven Episoden, bipolarer Störung, Dermatillomanie (skin picking disorder), Missbrauchserfahrungen und niedriger Lebensqualität assoziiert (Nunes-Neto et al., 2018). Da sich in der Öffentlichkeit verstärkt Personen selbst als süchtig nach Essen bezeichnen, erstellten Meadows und Kollegen eine Studie, um „Diagnosen“ mittels der YFAS 2.0 (8,5 \%) mit subjektiv empfundener Food Addiction (52,0\%) zu vergleichen (Meadows, Nolan, \& Higgs, 2017). Subjektiv wahrgenommene Food Addiction war mit problematischem Essverhalten, Bedenken bezüglich des Körperbildes und psychischen Erkrankungen assoziiert. Das Empfinden von Kontrollverlust beim Essen war das Hauptdistinktionsmerkmal zwischen Personen mit und ohne Food Addiction. Die Schweregrade von Craving und Depressionen konnten am besten zwischen Food Addiction nach YFAS 2.0 und selbstbezeichneter Food Addiction distinguieren (Meadows et al., 2017). Sexuelle Minderheiten (17,5\%) stellen zudem im Vergleich zu heterosexuellen Personen (9,9\%) eine Risikogruppe für Food Addiction dar (Rainey, Furman, \& Gearhardt, 2018). In einer systematischen Übersichtsarbeit aus der bariatrischen Chirurgie zeigten sich prä-operativ Food Addiction-Raten zwischen 14 und 57,8 \%, und post-operativ Raten zwischen zwei 
und 13,7\%. Eine „Food Addiction-Diagnose" war dabei zudem mit pathologischem Essverhalten und psychischen Erkrankungen assoziiert (Ivezaj, Wiedemann, \& Grilo, 2017).

Um mögliche beeinflussende Lebensmittel für Food Addiction zu ermitteln, wurden Verzehrsdaten aus der Nurses' Health Study II mit „Diagnosen“ einer Food Addiction nach YFAS assoziiert (Lemeshow et al., 2018). Es zeigten sich höhere Wahrscheinlichkeiten für eine Food Addiction bei hohem Konsum ( $\geq 5$ Woche) von Hamburgern, Pommes und Pizza im Vergleich zu einem niedrigen Konsum (< 1/Monat). Positiv mit Food Addiction assoziiert war der Konsum von rotem/prozessiertem Fleisch, fettarmen Snacks/Desserts und kalorienreduzierten Getränken. Negativ assoziiert mit Food Addiction war dagegen der Konsum von raffiniertem Getreide, gesüßten Getränken, Obst, Gemüse und Hülsenfrüchten. Daraus folgerten die Autoren, dass vor allem hochverarbeitete Lebensmittel mit einer Kombination aus Kohlenhydraten und Fett mit suchtartigem Essverhalten assoziiert sind, Kohlenhydrate allein jedoch nicht (Lemeshow et al., 2018). Ähnliche Ergebnisse wurden von Pursey und Kollegen (Pursey, Davis, \& Burrows, 2017) berichtet. Die Arbeitsgruppe stufte zudem den Gesamtfettgehalt und den glykämischen Index von Lebensmitteln als bedeutsame Faktoren ein (Pursey, Davis, \& Burrows, 2017). Diese aktuellen Forschungsergebnisse zeigen, dass hochverarbeitete Lebensmittel nicht per se mit Symptomen einer Food Addiction assoziiert sind. Beispielsweise gab es in der Nurses' Health Study II eine inverse, beziehungsweise keine Korrelation des Verzehrs bestimmter süßer Lebensmittel, hochverarbeiteter Getreideprodukte und zuckergesüßter Getränke mit Food Addiction (Lemeshow et al., 2018). Die stoffliche Seite einer Food Addiction beim Menschen bedarf weiterer Forschung.

Kinder und Jugendliche stellen eine interessante Zielgruppe für die Forschung zu pathologischem Essverhalten dar, da sich pathologisches Essverhalten höchstwahrscheinlich während der Kindheit und Adoleszenz entwickelt (Mies et al., 2017). Für Kinder und Jugendliche wurde daher ein angepasster Fragebogen, die YFAS-C entwickelt (Gearhardt, Roberto, Seamans, Corbin, \& Brownell, 2013). Vorliegende Dissertationsarbeit befasst sich ausschließlich mit Erwachsenen, daher wird auf Ergebnisse der YFAS-C in dieser Arbeit nicht näher eingegangen. 


\subsection{Sport, Sportsucht und Food Addiction}

Personen mit pathologischem Essverhalten zeigen häufig auch exzessives Sporttreiben. Die Zusammenhänge zwischen sportlicher Aktivität und Essstörungen sind jedoch bis heute nicht abschließend geklärt (Zeeck \& Schlegel, 2012). Da Food Addiction pathologisches Essverhalten zeigt und noch keine Zusammenhänge zwischen Food Addiction und exzessivem Sportverhalten untersucht wurden, sollen in Kapitel 5 erstmals weltweit potentielle Zusammenhänge zwischen pathologischem Ess- (Food Addiction) und Sportverhalten (Sportsucht) untersucht werden. Zunächst sollen die Begriffe „Sport“ und „Sportsucht“ kurz erläutert werden.

Der Begriff Sport hat sich „(...) zu einem umgangssprachlichen, weltweit gebrauchten Begriff entwickelt. Eine präzise oder gar eindeutige begriffliche Abgrenzung lässt sich deshalb nicht vornehmen" (Röthig \& Prohl, 2003). Vorliegende Arbeit legt deshalb den Sportbegriff aus dem Leitbild des Deutschen Olympischen Sportbundes (DOSB) zu Grunde (Deutscher Sportbund, 2000). Dieser besagt, dass Sport „Freude an körperlicher Leistung, das Bedürfnis nach Vergleich und die für den Einzelnen wie für die Gemeinschaft identitätsstiftende Wirkung des Wettkampfsports“ (Deutscher Sportbund, 2000) bedeutet. Im Vordergrund stehen die eigenmotorische Aktivität der Betätigung und die Einhaltung ethischer Werte, wie zum Beispiel Fairplay (Deutscher Sportbund, 2000). Regelmäßiger sportlicher Aktivität werden gesundheitsförderliche Auswirkungen und die Entwicklung positiver Gefühle zugeschrieben (Williams \& Marcus, 2012). Die amerikanische Gesellschaft für Sportmedizin empfiehlt daher mindestens 150 Minuten moderate, oder 75 Minuten intensive, körperliche Aktivität pro Woche (Pescatello \& American College of Sports Medicine, 2014). In vorliegender Dissertationsarbeit wurde eine Mindestanzahl an 240 Minuten sportlicher Aktivität pro Woche zur Bezeichnung einer Person als „leistungsorientierter Ausdauersportler“ definiert (siehe Kapitel 5). Die Grundannahmen für die Einteilung liegt darin, dass eine Person den Sport dann in ihren Alltag integriert habe (Hauck, Schipfer, Ellrott, \& Cook, n.d.).

Sportliche Aktivität gilt zunächst als gesundheitsförderliche und positive Verhaltensweise, kann jedoch auch auf ungesunde Weise betrieben werden (Zeeck \& Schlegel, 2012). So kann es bei einer kleinen Gruppe von Sportlern (< $5 \%$; (Allegre, Souville, Therme, \& Griffiths, 2006) zur Entwicklung exzessiven Sporttreibens, bis hin zu einer Sportsucht kommen. Zunächst wurde Sportsucht wegen der primär gesundheitlichen Vorteile als „positive Sucht“ bezeichnet (Glasser, 
1976). Von einer Sportsucht wird gesprochen, wenn schädliche biologische (Entzugssymptome und Toleranzentwicklung) und behaviorale (Kontrollverlust, Beeinträchtigungen) Komponenten vorliegen (Allegre et al., 2006). Abgegrenzt wird die Sportsucht von einer Sportbindung, wo zwar eine starke Sportfokussierung vorliegt, die negativen biologischen und behavioralen Komponenten jedoch nicht vorhanden sind. Zudem wird in primäre und sekundäre Sportsucht unterschieden. Bei einer sekundären Sportsucht tritt das exzessive Sporttreiben im Rahmen einer Essstörung auf (Veale, 1995).

Die Gruppe der Ausdauersportler stellt eine gefährdete Gruppe für Essstörungen dar (Sundgot-Borgen \& Torstveit, 2004). Denn bei diesen Athleten kann ein niedriges Körpergewicht zu einem leistungssteigernden Effekt führen. Gleichzeitig besteht jedoch - durch das intensive Training - ein hoher Energiebedarf. Einige Ausdauerathleten zeigen daher Schwierigkeiten des Gewichtsmanagements (Fogelholm, 1994). Daher scheint die Gruppe der leistungsorientierten Ausdauersportler eine geeignete Gruppe zur Untersuchung von Food Addiction darzustellen (siehe Kapitel 5).

Suchterkrankungen können koexistent auftreten (Sussman, 2017). Erste Forschungsarbeiten zu Ko-Existenzen von Food Addiction und anderen Suchterkrankungen wurden bereits konzipiert (Jiménez-Murcia et al., 2017), zu Sportsucht und Food Addiction liegen derzeit jedoch noch keine Publikationen vor. Da sowohl Food Addiction, als auch Sport potentielle Suchterkrankungen darstellen, soll in vorliegender Dissertationsarbeit auch dieser Aspekt mit untersucht werden (siehe Kapitel 5).

\subsection{Forschungslücken}

Zum Zeitpunkt des Forschungsbeginns vorliegender Dissertationsarbeit Mitte des Jahres 2015, lagen weder in Deutschland, noch in anderen Staaten bevölkerungsrepräsentative Daten zu suchtartigem Essverhalten vor. Ohne verlässliche Zahlen zur Prävalenz einer Krankheit, kann die Bedeutung dieser für die Gesellschaft (Morbidität, Mortalität, sozioökonomische Kosten) nicht eingeschätzt werden. Aus diesem Grund wurde in vorliegender Dissertationsarbeit erstmals die Prävalenz von Food Addiction erhoben, die repräsentativ für die deutsche Erwachsenenbevölkerung ist (siehe Kapitel 3). 
Um Food Addiction näher charakterisieren und einordnen zu können, sind zudem beeinflussende Faktoren von großer Bedeutung. Deshalb wurden in den beiden Folge-Studien unter anderem weitere Parameter des Essverhaltens erfragt (siehe Kapitel 3, 4 und 5). Gerade Personen mit hohem Körpergewicht stellen eine Population mit Herausforderungen für die Gesellschaft und das Gesundheitssystem dar (Kolotkin et al., 2001; Rebscher et al., 2016). Falls Food Addiction einen Erklärungsansatz für die zunehmende Adipositasprävalenz liefern kann, sind unter Umständen neue Ansätze in Prävention und Therapie möglich. Auch leistungsorientierte Sportler stellen eine Personengruppe dar, die anfällig für gestörtes Essverhalten, sowie Sportsucht scheint (Sundgot-Borgen \& Torstveit, 2004). Da Personen mit morbider Adipositas und Ausdauerathleten noch nicht hinreichend auf suchtartiges Essverhalten hin untersucht wurden, können vorliegende Studien neue Erkenntnisse hierzu liefern. Einen weiteren Forschungsansatz bilden die potentielle Überschneidung zwischen Food Addiction und Essstörungen. Die Dissertation war nicht dazu konzipiert, zu dieser Forschungsfrage beizutragen, jedoch sind Forschungsvorhaben in Planung.

Die Dissertationsarbeit wurde dazu konzipiert, neue Erkenntnisse zu dem noch relativ jungen Konstrukt der „Food Addiction“ zu liefern und zur weiteren Aufklärung des Konstruktes beizutragen.

\section{Literaturverzeichnis Teil 1 - Einleitung}

Abizaid, A., Gao, Q., \& Horvath, T. L. (2006). Thoughts for Food: Brain Mechanisms and Peripheral Energy Balance. Neuron, 51(6), 691-702. https://doi.org/10.1016/j.neuron.2006.08.025 Ahmed, S. H., Avena, N. M., Berridge, K. C., Gearhardt, A. N., \& Guillem, K. (2013). Food Addiction. In D. W. Pfaff (Ed.), Neuroscience in the 21st Century (pp. 2833-2857). New York, NY: Springer New York. Retrieved from http://link.springer.com/10.1007/978-1-4614-1997-6_110 


\section{Teil 1 Einleitung}

Albayrak, Ö., \& Hebebrand, J. (2015). Ist Ess-Sucht eine Verhaltenssucht? PPmP - Psychotherapie . Psychosomatik · Medizinische Psychologie, 65(1), 39-41. https://doi.org/10.1055/s-00341394412

Albayrak, Ö., Kliewer, J., Föcker, M., Antel, J., \& Hebebrand, J. (2015). Food Addiction: Nahrungsmittelabhängigkeit oder Ess-Verhaltenssucht? Zeitschrift für Kinder- und Jugendpsychiatrie und Psychotherapie, 43(3), 173-183. https://doi.org/10.1024/14224917/a000355

Albayrak, Ö., Wölfle, S. M., \& Hebebrand, J. (2012). Does Food Addiction Exist? A Phenomenological Discussion Based on the Psychiatric Classification of Substance-Related Disorders and Addiction. Obesity Facts, 5(2), 165-179. https://doi.org/10.1159/000338310

Allegre, B., Souville, M., Therme, P., \& Griffiths, M. (2006). Definitions and measures of exercise dependence. Addiction Research \& Theory, 14(6), 631-646. https://doi.org/10.1080/16066350600903302

American Psychiatric Association (Ed.). (1998). Diagnostic and statistical manual of mental disorders: DSM-IV ; includes ICD-9-CM codes effective 1. Oct. 96 (4. ed., 7. print). Washington, DC. American Psychiatric Association (Ed.). (2013). Diagnostic and statistical manual of mental disorders: DSM-5 (5. ed). Washington, DC: American Psychiatric Publ.

American Psychiatric Association, \& American Psychiatric Association (Eds.). (2009). Diagnostic and statistical manual of mental disorders: DSM-IV-TR (4. ed., text revision, 13. print). Arlington, VA: American Psychiatric Assoc.

Avena, N. M., Bocarsly, M. E., Rada, P., Kim, A., \& Hoebel, B. G. (2008). After daily bingeing on a sucrose solution, food deprivation induces anxiety and accumbens dopamine/acetylcholine imbalance. Physiology \& Behavior, 94(3), 309-315. https://doi.org/10.1016/j.physbeh.2008.01.008

Avena, N. M., Gearhardt, A. N., Gold, M. S., Wang, G.-J., \& Potenza, M. N. (2012). Tossing the baby out with the bathwater after a brief rinse? The potential downside of dismissing food 


\section{Teil 1 Einleitung}

addiction based on limited data. Nature Reviews Neuroscience, 13(7), 514-514.

https://doi.org/10.1038/nrn3212-c1

Avena, N. M., Long, K. A., \& Hoebel, B. G. (2005). Sugar-dependent rats show enhanced responding for sugar after abstinence: Evidence of a sugar deprivation effect. Physiology \& Behavior, 84(3), 359-362. https://doi.org/10.1016/j.physbeh.2004.12.016

Avena, N. M., Rada, P., \& Hoebel, B. G. (2008a). Evidence for sugar addiction: Behavioral and neurochemical effects of intermittent, excessive sugar intake. Neuroscience \& Biobehavioral Reviews, 32(1), 20-39. https://doi.org/10.1016/j.neubiorev.2007.04.019

Avena, N. M., Rada, P., \& Hoebel, B. G. (2008b). Evidence for sugar addiction: Behavioral and neurochemical effects of intermittent, excessive sugar intake. Neuroscience \& Biobehavioral Reviews, 32(1), 20-39. https://doi.org/10.1016/j.neubiorev.2007.04.019

Axel, R. (2005). Scents and Sensibility: A Molecular Logic of Olfactory Perception (Nobel Lecture). Angewandte Chemie International Edition, 44(38), 6110-6127. https://doi.org/10.1002/anie.200501726

Barbano, M. F., \& Cador, M. (2007). Opioids for hedonic experience and dopamine to get ready for it. Psychopharmacology, 191(3), 497-506. https://doi.org/10.1007/s00213-006-0521-1

Bardone-Cone, A. M., Wonderlich, S. A., Frost, R. O., Bulik, C. M., Mitchell, J. E., Uppala, S., \& Simonich, H. (2007). Perfectionism and eating disorders: Current status and future directions. Clinical Psychology Review, 27(3), 384-405. https://doi.org/10.1016/j.cpr.2006.12.005

Barry, D., Clarke, M., \& Petry, N. M. (2009). Obesity and Its Relationship to Addictions: Is Overeating a Form of Addictive Behavior? American Journal on Addictions, 18(6), 439-451. https://doi.org/10.3109/10550490903205579

Bech, P. (2004). Measuring the Dimension of Psychological General Well-Being by the WHO-5. QoL Newsletter, 2004(32), 15-16.

Bech, P., Olsen, L. R., Kjoller, M., \& Rasmussen, N. K. (2003). Measuring well-being rather than the absence of distress symptoms: a comparison of the SF-36 Mental Health subscale and the 


\section{Teil 1 Einleitung}

WHO-Five well-being scale. International Journal of Methods in Psychiatric Research, 12(2), 85-91. https://doi.org/10.1002/mpr.145

Benton, D. (2010). The plausibility of sugar addiction and its role in obesity and eating disorders. Clinical Nutrition, 29(3), 288-303. https://doi.org/10.1016/j.clnu.2009.12.001

Bergler, R., Güttner, G., Knöferl, G., Schmalbach, I., Marquardt, W., Holländer, A., ... Scherl, H. (2002). Genuss - Eine Bedeutungsanalyse und Normanalyse. In Genuss und Gesundheit (p. 39). Köln: Kölner Univ.-Verl.

Bergler, R., \& Hoff, T. (2002). Genuss und Gesundheit. Köln: Kölner Univ.-Verl.

Berridge, K. C. (1996). Food reward: brain substrates of wanting and liking. Neuroscience and Biobehavioral Reviews, 20(1), 1-25.

Berthoud, H.-R. (2011). Metabolic and hedonic drives in the neural control of appetite: who is the boss? Current Opinion in Neurobiology, 21(6), 888-896.

https://doi.org/10.1016/j.conb.2011.09.004

Bibliographisches Institut GmbH. (2017). Genuss, der. Retrieved from http://www.duden.de/rechtschreibung/Genuss

Bibliographisches Institut GmbH. (n.d.). DUDEN. Retrieved August 12, 2016, from http://www.duden.de/rechtschreibung/Sucht

Birbaumer, N., \& Schmidt, R. F. (2010). Biologische Psychologie: mit 44 Tabellen (7., überarb. und Aufl). Heidelberg: Springer Medizin.

Brähler, E., Mühlan, H., Albani, C., \& Schmidt, S. (2007). Teststatistische Prüfung und Normierung der deutschen Versionen des EUROHIS-QOL Lebensqualität-Index und des WHO-5 Wohlbefindens-Index. Diagnostica, 53(2), 83-96. https://doi.org/10.1026/0012-1924.53.2.83

Breuer, S., \& Kleinert, J. (2009). Primäre Sportsucht und bewegungsbezogene Abhängigkeit Beschreibung, Erklärung und Diagnostik. In Rausch ohne Drogen: substanzungebundene Süchte (pp. 191-218). Wien: Springer.

Brownell, K. D., \& Gold, M. S. (2012a). Food and Addiction. In K. D. Brownell \& M. S. Gold (Eds.), Food and Addiction (pp. 439-446). Oxford University Press. Retrieved from 


\section{Teil 1 Einleitung}

http://www.oxfordclinicalpsych.com/view/10.1093/med:psych/9780199738168.001.0001/m ed-9780199738168-chapter-66

Brownell, K. D., \& Gold, M. S. (Eds.). (2012b). Food and addiction: a comprehensive handbook (1. ed). Oxford: Oxford Univ. Press.

Brunault, P., Courtois, R., Gearhardt, A. N., Gaillard, P., Journiac, K., Cathelain, S., ... Ballon, N. (2017). Validation of the French Version of the DSM-5 Yale Food Addiction Scale in a Nonclinical Sample. The Canadian Journal of Psychiatry, 62(3), 199-210.

https://doi.org/10.1177/0706743716673320

Bullinger, M., Kirchberger, I., \& Ware, J. (1995). Der deutsche SF-36 Health Survey Übersetzung und psychometrische Testung eines krankheitsübergreifenden Instruments zur Erfassung der gesundheitsbezogenen Lebensqualität. Journal of Public Health, 3(1), 21-36. https://doi.org/10.1007/BF02959944

Bundesministerium. (2015). Deutschland, wie es isst - Der BMEL-Ernährungsreport 2016. Berlin: BMEL.

Canetti, L., Bachar, E., \& Berry, E. M. (2002). Food and emotion. Behavioural Processes, 60(2), 157164.

Carter, A., Hendrikse, J., Lee, N., Yücel, M., Verdejo-Garcia, A., Andrews, Z., \& Hall, W. (2016). The Neurobiology of "Food Addiction" and Its Implications for Obesity Treatment and Policy. Annual Review of Nutrition, 36(1), 105-128. https://doi.org/10.1146/annurev-nutr-071715050909

Center for Behavioral Health Statistics and Quality. (2015). Behavioral health trends in the United States: Results from the 2014 National Survey on Drug Use and Health (No. SMA 15-4927, NSDUH Series H-50) (p. 64). Retrieved from http://www.samhsa.gov/ data/

Chandrashekar, J., Hoon, M. A., Ryba, N. J. P., \& Zuker, C. S. (2006). The receptors and cells for mammalian taste. Nature, 444(7117), 288-294. https://doi.org/10.1038/nature05401

Cohen, J. (1988). Statistical power analysis for the behavioral sciences (2. ed., reprint). New York, NY: Taylor \& Francis Inc. 


\section{Teil 1 Einleitung}

Cohen, J. (1992). A power primer. Psychological Bulletin, 112(1), 155-159.

Cook, B., Hausenblas, H., \& Freimuth, M. (2014). Exercise Addiction and Compulsive Exercising: Relationship to Eating Disorders, Substance Use Disorders, and Addictive Disorders. In T. D. Brewerton \& A. Baker Dennis (Eds.), Eating Disorders, Addictions and Substance Use Disorders (pp. 127-144). Berlin, Heidelberg: Springer Berlin Heidelberg. Retrieved from http://link.springer.com/10.1007/978-3-642-45378-6_7

Cook, B., Karr, T. M., Zunker, C., Mitchell, J. E., Thompson, R., Sherman, R., ... Wonderlich, S. A. (2013). Primary and Secondary Exercise Dependence in a Community-Based Sample of Road Race Runners. Journal of Sport and Exercise Psychology, 35(5), 464-469. https://doi.org/10.1123/jsep.35.5.464

Cooney, N. L., Litt, M. D., Morse, P. A., Bauer, L. O., \& Gaupp, L. (1997). Alcohol cue reactivity, negative-mood reactivity, and relapse in treated alcoholic men. Journal of Abnormal Psychology, 106(2), 243-250.

Corwin, R. L. W., \& Hayes, J. E. (2014). Are Sugars Addictive? Perspectives for Practitioners. In J. M. Rippe (Ed.), Fructose, High Fructose Corn Syrup, Sucrose and Health (pp. 199-215). New York, NY: Springer New York. Retrieved from http://link.springer.com/10.1007/978-1-4899-80779_13

Costa, S., Hausenblas, H. A., Oliva, P., Cuzzocrea, F., \& Larcan, R. (2016). Maladaptive perfectionism as mediator among psychological control, eating disorders, and exercise dependence symptoms in habitual exerciser. Journal of Behavioral Addictions, 5(1), 77-89. https://doi.org/10.1556/2006.5.2016.004

Cota, D., Tschöp, M. H., Horvath, T. L., \& Levine, A. S. (2006). Cannabinoids, opioids and eating behavior: The molecular face of hedonism? Brain Research Reviews, 51(1), 85-107. https://doi.org/10.1016/j.brainresrev.2005.10.004

Davis, C. (2016). A commentary on the associations among "food addiction", binge eating disorder, and obesity: Overlapping conditions with idiosyncratic clinical features. Appetite, 1-6. https://doi.org/10.1016/j.appet.2016.11.001 


\section{Teil 1 Einleitung}

Davis, C., \& Carter, J. C. (2009). Compulsive overeating as an addiction disorder. A review of theory and evidence. Appetite, 53(1), 1-8. https://doi.org/10.1016/j.appet.2009.05.018

Davis, C., \& Claridge, G. (1998). The eating disorders as addiction: a psychobiological perspective. Addictive Behaviors, 23(4), 463-475.

Davis, C., Curtis, C., Levitan, R. D., Carter, J. C., Kaplan, A. S., \& Kennedy, J. L. (2011). Evidence that "food addiction" is a valid phenotype of obesity. Appetite, 57(3), 711-717. https://doi.org/10.1016/j.appet.2011.08.017

Davis, C., Levitan, R. D., Kaplan, A. S., Carter, J., Reid, C., Curtis, C., ... Kennedy, J. L. (2008). Reward sensitivity and the D2 dopamine receptor gene: A case-control study of binge eating disorder. Progress in Neuro-Psychopharmacology and Biological Psychiatry, 32(3), 620-628. https://doi.org/10.1016/j.pnpbp.2007.09.024

de Vries, S.-K., \& Meule, A. (2016). Food Addiction and Bulimia Nervosa: New Data Based on the Yale Food Addiction Scale 2.0: Food Addiction and Bulimia. European Eating Disorders Review, 24(6), 518-522. https://doi.org/10.1002/erv.2470

de Wit, H. (2009). Impulsivity as a determinant and consequence of drug use: a review of underlying processes: Impulsivity and drug use. Addiction Biology, 14(1), 22-31. https://doi.org/10.1111/j.1369-1600.2008.00129.x

Deutsche Adipositas-Gesellschaft (DAG) e.V., Deutsche Diabetes Gesellschaft (DDG), Deutsche Gesellschaft für Ernährung e. V. (DGE), \& Deutsche Gesellschaft für Ernährungsmedizin (DGEM) e.V. (Hrsg.). (2014). Interdisziplinäre Leitlinie der Qualität S3 zur „Prävention und Therapie der Adipositas". Version 2.0 (April 2014) (No. Version 2.0). Retrieved from www.awmf.org/leitlinien/detail/II/050-001.html

Deutscher Sportbund. (2000, September 12). Einheit in der Vielfalt - Leitbild des deutschen Sports. Retrieved from https://www.dosb.de/de/organisation/was-ist-sport/sportdefinition/ DGEintern. (2017). 10 Regeln der DGE aktualisiert (Presseinformation). Bonn: Deutsche Gesellschaft für Ernährung e . V. (DGE). 


\section{Teil 1 Einleitung}

Di Chiara, G., \& Imperato, A. (1988). Drugs abused by humans preferentially increase synaptic dopamine concentrations in the mesolimbic system of freely moving rats. Proceedings of the National Academy of Sciences of the United States of America, 85(14), 5274-5278.

Ditzen, B., Bodenmann, G., Ehlert, U., \& Heinrichs, M. (2006). Effects of social support and oxytocin on psychological and physiological stress responses during marital conflict. Frontiers in Neuroendocrinology, 27(1), 134. https://doi.org/10.1016/j.yfrne.2006.03.279

Drewnowski, A., Krahn, D. D., Demitrack, M. A., Nairn, K., \& Gosnell, B. A. (1995). Naloxone, an opiate blocker, reduces the consumption of sweet high-fat foods in obese and lean female binge eaters. The American Journal of Clinical Nutrition, 61(6), 1206-1212.

Feng, Y., He, X., Yang, Y., Chao, D., Lazarus, L. H., \& Xia, Y. (2012). Current research on opioid receptor function. Current Drug Targets, 13(2), 230-246.

Finlayson, G. (2017). Food addiction and obesity: unnecessary medicalization of hedonic overeating. Nature Reviews Endocrinology, 13(8), 493-498. https://doi.org/10.1038/nrendo.2017.61

Finlayson, G., \& Dalton, M. (2012). Hedonics of Food Consumption: Are Food "Liking" and "Wanting" Viable Targets for Appetite Control in the Obese? Current Obesity Reports, 1(1), 42-49. https://doi.org/10.1007/s13679-011-0007-2

Fogelholm, M. (1994). Effects of bodyweight reduction on sports performance. Sports Medicine (Auckland, N.Z.), 18(4), 249-267.

Food Addicts Anonymous. (n.d.). Food Addicts Anonymous. Retrieved January 25, 2018, from https://www.foodaddictsanonymous.org/

Forsberg, S., \& Lock, J. (2006). The relationship between perfectionism, eating disorders and athletes: a review. Minerva Pediatrica, 58(6), 525-536.

forum. ernährung heute. (2010). Kulinarische Intelligenz - Genuss ist Lebensqualität. Presented at the 1. f.eh-Symposium, Wien. Retrieved from http://www.forumernaehrung.at/events/kulinarische-intelligenz-genuss-ist-lebensqualitaet/

Fowler, J. S., Volkow, N. D., Kassed, C. A., \& Chang, L. (2007). Imaging the addicted human brain. Science \& Practice Perspectives, 3(2), 4-16. 


\section{Teil 1 Einleitung}

Freud, S. (2017). Das Ich und das Es. Köln: Anaconda.

Fromme, S. (2017). Mit Genuss überzeugen, (3/17), 144.

Garber, C. E., Blissmer, B., Deschenes, M. R., Franklin, B. A., Lamonte, M. J., Lee, I.-M., ... Swain, D. P. (2011). Quantity and Quality of Exercise for Developing and Maintaining Cardiorespiratory, Musculoskeletal, and Neuromotor Fitness in Apparently Healthy Adults: Guidance for Prescribing Exercise. Medicine \& Science in Sports \& Exercise, 43(7), 1334-1359. https://doi.org/10.1249/MSS.0b013e318213fefb

Gearhardt, A. N. (2011). Neural Correlates of Food Addiction. Archives of General Psychiatry, 68(8), 808. https://doi.org/10.1001/archgenpsychiatry.2011.32

Gearhardt, A. N., \& Corbin, W. R. (2012). Food Addiction and Diagnostic Criteria for Dependence. In K. D. Brownell \& M. S. Gold (Eds.), Food and Addiction (pp. 167-171). Oxford University Press. Retrieved from http://www.oxfordclinicalpsych.com/view/10.1093/med:psych/9780199738168.001.0001/m ed-9780199738168-chapter-25

Gearhardt, A. N., Corbin, W. R., \& Brownell, K. D. (2009a). Food Addiction: An Examination of the Diagnostic Criteria for Dependence. Journal of Addiction Medicine, 3(1), 1-7. https://doi.org/10.1097/ADM.0b013e318193c993

Gearhardt, A. N., Corbin, W. R., \& Brownell, K. D. (2009b). Preliminary validation of the Yale Food Addiction Scale. Appetite, 52(2), 430-436. https://doi.org/10.1016/j.appet.2008.12.003

Gearhardt, A. N., Corbin, W. R., \& Brownell, K. D. (2016). Development of the Yale Food Addiction Scale Version 2.0. Psychology of Addictive Behaviors, 30(1), 113-121. https://doi.org/10.1037/adb0000136

Gearhardt, A. N., Davis, C., Kuschner, R., \& Brownell, K. D. (2011). The addiction potential of hyperpalatable foods. Current Drug Abuse Reviews, 4(3), 140-145.

Gearhardt, A. N., Roberto, C. A., Seamans, M. J., Corbin, W. R., \& Brownell, K. D. (2013). Preliminary validation of the Yale Food Addiction Scale for children. Eating Behaviors, 14(4), 508-512. https://doi.org/10.1016/j.eatbeh.2013.07.002 


\section{Teil 1 Einleitung}

Glaesmer, H., Grande, G., Braehler, E., \& Roth, M. (2011). The German Version of the Satisfaction With Life Scale (SWLS): Psychometric Properties, Validity, and Population-Based Norms. European Journal of Psychological Assessment, 27(2), 127-132. https://doi.org/10.1027/1015-5759/a000058

Glasser, W. (1976). Positive Addiction. New York: Harper \& Row Publ.

Gold, M. S., Frost-Pineda, K., \& Jacobs, W. S. (2003). Overeating, Binge Eating, and Eating Disorders as Addictions. Psychiatric Annals, 33(2), 117-122. https://doi.org/10.3928/0048-571320030201-08

Granero, R., Hilker, I., Agüera, Z., Jiménez-Murcia, S., Sauchelli, S., Islam, M. A., ... Fernández-Aranda, F. (2014). Food Addiction in a Spanish Sample of Eating Disorders: DSM-5 Diagnostic Subtype Differentiation and Validation Data: Food Addiction and ED Subtypes. European Eating Disorders Review, 22(6), 389-396. https://doi.org/10.1002/erv.2311

Greenfield, S. F., \& Crisafulli, M. A. (2012). Co-Occurring Addiction and Psychiatric Disorders. In K. D. Brownell \& M. S. Gold (Eds.), Food and Addiction (pp. 47-52). Oxford University Press. Retrieved from http://www.oxfordclinicalpsych.com/view/10.1093/med:psych/9780199738168.001.0001/m ed-9780199738168-chapter-7

Grimm, J., \& Grimm, W. (1998a). Deutsches Wörterbuch von Jacob Grimm und Wilhelm Grimm (Vol. 5 Sp. 3477). Trier: Trier Center for Digital Humanities / Kompetenzzentrum für elektronische Erschließungs- und Publikationsverfahren in den Geisteswissenschaften an der Universität Trier. Retrieved from http://woerterbuchnetz.de/cgi-bin/WBNetz/wbgui_py?sigle=DWB Grimm, J., \& Grimm, W. (1998b). Deutsches Wörterbuch von Jacob Grimm und Wilhelm Grimm (Vol. 5, Sp. 3518). Trier: Trier Center for Digital Humanities / Kompetenzzentrum für elektronische Erschließungs- und Publikationsverfahren in den Geisteswissenschaften an der Universität Trier. Retrieved from http://woerterbuchnetz.de/cgi-bin/WBNetz/wbgui_py?sigle=DWB Gruber, M. (2011). Salutogenetische Aspekte des kulinarischen Genießens. Ernährung \&amp; Medizin, 26(3), 115-119. https://doi.org/10.1055/s-0031-1286126 


\section{Teil 1 Einleitung}

Haenel, H. (1990). Ernährung - Gesundheit - Genuss. Wissenschaftliche Zeitschrift der HumboldtUniversität zu Berlin. Reihe Medizin., 219-221.

Hall, H. K., Hill, A. P., Appleton, P. R., \& Kozub, S. A. (2009). The mediating influence of unconditional self-acceptance and labile self-esteem on the relationship between multidimensional perfectionism and exercise dependence. Psychology of Sport and Exercise, 10(1), 35-44. https://doi.org/10.1016/j.psychsport.2008.05.003

Hauck, C., \& Ellrott, T. (2017). ,Food addiction` - addictive-like eating behavior. The current state of research with the Yale Food Addiction Scale. Ernahrungs Umschau, 102-110. https://doi.org/10.4455/eu.2017.023

Hauck, C., \& Ellrott, T. (n.d.). Was und wie genießt Deutschland 2017? (unveröffentlichte Daten).

Hauck, C., Schipfer, M., Ellrott, T., \& Cook, B. (n.d.). Food Addiction, exercise dependence and perfectionism in amateur athletes. Under Review.

Hauck, C., Weiß, A., \& Ellrott, T. (2016). Relationship between "food addiction", restrained eating behavior, mental health status and score of binge eating in a morbidly obese German sample. Adipositas, 10(4), 215-220.

Hauck, C., Weiß, A., Schulte, E. M., Meule, A., \& Ellrott, T. (2017a). Prevalence of "Food Addiction" as Measured with the Yale Food Addiction Scale 2.0 in a Representative German Sample and Its Association with Sex, Age and Weight Categories. Obesity Facts, 10(1), 12-24. https://doi.org/10.1159/000456013

Hauck, C., Weiß, A., Schulte, E. M., Meule, A., \& Ellrott, T. (2017b). Prevalence of "Food Addiction" as Measured with the Yale Food Addiction Scale 2.0 in a Representative German Sample and Its Association with Sex, Age and Weight Categories. Obesity Facts, 12-24. https://doi.org/10.1159/000456013

Hebebrand, J., Albayrak, Ö., Adan, R., Antel, J., Dieguez, C., de Jong, J., ... Dickson, S. L. (2014). “Eating addiction", rather than "food addiction", better captures addictive-like eating behavior. Neuroscience \& Biobehavioral Reviews, 47, 295-306. https://doi.org/10.1016/j.neubiorev.2014.08.016 


\section{Teil 1 Einleitung}

Henning, W., Kaftan, B., \& Kuhnke, R. (2002). Ein psychologisches Wertorientierungskonzept und seine Umsetzung in ein empirisches Analyseverfahren. In Genuss und Gesundheit (p. 59f.). Köln: Kölner Univ.-Verl.

Herpertz, S., Zwaan, M. de, \& Zipfel, S. (Eds.). (2015). Handbuch Essstörungen und Adipositas: mit 42 Abbildungen und 31 Tabellen (2. Auflage). Berlin, Heidelberg: Springer.

Hetherington, M. M., \& Macdiarmid, J. I. (1993). "Chocolate Addiction”: a Preliminary Study of its Description and its Relationship to Problem Eating. Appetite, 21(3), 233-246. https://doi.org/10.1006/appe.1993.1042

Hill, A. P., Robson, S. J., \& Stamp, G. M. (2015). The predictive ability of perfectionistic traits and selfpresentational styles in relation to exercise dependence. Personality and Individual Differences, 86, 176-183. https://doi.org/10.1016/j.paid.2015.06.015

Hodgson, R. J., \& Greene, J. B. (1980). The saliva priming effect, eating speed and the measurement of hunger. Behaviour Research and Therapy, 18(4), 243-247. https://doi.org/10.1016/00057967(80)90081-9

Hoebel, B. G., Avena, N. M., Bocarsly, M. E., \& Rada, P. (2009). Natural Addiction: A Behavioral and Circuit Model Based on Sugar Addiction in Rats. Journal of Addiction Medicine, 3(1), 33-41. https://doi.org/10.1097/ADM.0b013e31819aa621

Hoebel, B. G., Rada, P., Mark, G. P., \& Pothos, E. (1999). Neural systems for reinforcement and inhibition of behavior: Relevance to eating, addiction, and depression. Wellbeing: Foundations of Hedonic Psychology, 560-574.

Houben, K., Nederkoorn, C., \& Jansen, A. (2014). Eating on impulse: The relation between overweight and food-specific inhibitory control: Food-Specific Inhibition and Overweight. Obesity, 22(5), E6-E8. https://doi.org/10.1002/oby.20670

Hyman, S. E., Malenka, R. C., \& Nestler, E. J. (2006). NEURAL MECHANISMS OF ADDICTION: The Role of Reward-Related Learning and Memory. Annual Review of Neuroscience, 29(1), 565-598. https://doi.org/10.1146/annurev.neuro.29.051605.113009 


\section{Teil 1 Einleitung}

Ifland, J., Preuss, H. G., Marcus, M. T., Rourke, K. M., Taylor, W., \& Theresa Wright, H. (2015). Clearing the Confusion around Processed Food Addiction. Journal of the American College of Nutrition, 34(3), 240-243. https://doi.org/10.1080/07315724.2015.1022466

Ikemoto, S. (2007). Dopamine reward circuitry: Two projection systems from the ventral midbrain to the nucleus accumbens-olfactory tubercle complex. Brain Research Reviews, 56(1), 27-78. https://doi.org/10.1016/j.brainresrev.2007.05.004

Innamorati, M., Imperatori, C., Manzoni, G. M., Lamis, D. A., Castelnuovo, G., Tamburello, A., ... Fabbricatore, M. (2015). Psychometric properties of the Italian Yale Food Addiction Scale in overweight and obese patients. Eating and Weight Disorders - Studies on Anorexia, Bulimia and Obesity, 20(1), 119-127. https://doi.org/10.1007/s40519-014-0142-3

Ivezaj, V., Wiedemann, A. A., \& Grilo, C. M. (2017). Food addiction and bariatric surgery: a systematic review of the literature: Food addiction and bariatric surgery. Obesity Reviews, 18(12), 13861397. https://doi.org/10.1111/obr.12600

Jiménez-Murcia, S., Granero, R., Wolz, I., Baño, M., Mestre-Bach, G., Steward, T., ... FernándezAranda, F. (2017). Food Addiction in Gambling Disorder: Frequency and Clinical Outcomes. Frontiers in Psychology, 8. https://doi.org/10.3389/fpsyg.2017.00473

Johnson, K. V.-A., \& Dunbar, R. I. M. (2016). Pain tolerance predicts human social network size. Scientific Reports, 6(1). https://doi.org/10.1038/srep25267

Johnson, P. M., \& Kenny, P. J. (2010). Dopamine D2 receptors in addiction-like reward dysfunction and compulsive eating in obese rats. Nature Neuroscience, 13(5), 635-641. https://doi.org/10.1038/nn.2519

Joy, E., Kussman, A., \& Nattiv, A. (2016). 2016 update on eating disorders in athletes: A comprehensive narrative review with a focus on clinical assessment and management. British Journal of Sports Medicine, 50(3), 154-162. https://doi.org/10.1136/bjsports-2015-095735 Kampov-Polevoy, A. B., Alterman, A., Khalitov, E., \& Garbutt, J. C. (2006). Sweet preference predicts mood altering effect of and impaired control over eating sweet foods. Eating Behaviors, 7(3), 181-187. https://doi.org/10.1016/j.eatbeh.2005.09.005 


\section{Teil 1 Einleitung}

Kendler, K. S., Thornton, L. M., \& Pedersen, N. L. (2000). Tobacco consumption in Swedish twins reared apart and reared together. Archives of General Psychiatry, 57(9), 886-892.

Kleiner, K. D., Gold, M. S., Frostpineda, K., Lenzbrunsman, B., Perri, M. G., \& Jacobs, W. S. (2004). Body Mass Index and Alcohol Use. Journal of Addictive Diseases, 23(3), 105-118. https://doi.org/10.1300/J069v23n03_08

Kolotkin RL, Meter K, Williams GR (2001) Quality of life and obesity. Obesity Reviews 2(4): 219-229. doi: 10.1046/j.1467-789X.2001.00040.x

Koob, G. F. (2012). Neuroanatomy of Addiction. In K. D. Brownell \& M. S. Gold (Eds.), Food and Addiction (pp. 20-29). Oxford University Press. Retrieved from http://www.oxfordclinicalpsych.com/view/10.1093/med:psych/9780199738168.001.0001/m ed-9780199738168-chapter-3

Koob, G. F., \& Le Moal, M. (1997). Drug abuse: hedonic homeostatic dysregulation. Science (New York, N.Y.), 278(5335), 52-58.

Kumanyika, S. (2012). Addressing Disparities Related to Food Intake and Obesity. In K. D. Brownell \& M. S. Gold (Eds.), Food and Addiction (pp. 376-381). Oxford University Press. Retrieved from http://www.oxfordclinicalpsych.com/view/10.1093/med:psych/9780199738168.001.0001/m ed-9780199738168-chapter-56

Kunkel-Razum, K., Gallmann, P., Kunkel, M., Münzberg, F., \& Bibliographisches Institut Mannheim (Eds.). (2017). Duden - Die deutsche Rechtschreibung: auf der Grundlage der aktuellen amtlichen Rechtschreibregeln (27., völlig neu bearbeitete und erweiterte Auflage). Berlin: Dudenverlag.

Laboga, I., \& Techniker Krankenkasse. (2013). Iss was, Deutschland? Hamburg: Techniker Krankenkasse, Hauptverwaltung. Retrieved from http://nbn-resolving.de/urn:nbn:de:101:1201303197205

Latner, J. D., Puhl, R. M., Murakami, J. M., \& O’Brien, K. S. (2014). Food addiction as a causal model of obesity. Effects on stigma, blame, and perceived psychopathology. Appetite, 77, 79-84. https://doi.org/10.1016/j.appet.2014.03.004 


\section{Teil 1 Einleitung}

Leehr, E. J., Krohmer, K., Schag, K., Dresler, T., Zipfel, S., \& Giel, K. E. (2015). Emotion regulation model in binge eating disorder and obesity - a systematic review. Neuroscience \& Biobehavioral Reviews, 49, 125-134. https://doi.org/10.1016/j.neubiorev.2014.12.008

Lejoyeux, M., Avril, M., Richoux, C., Embouazza, H., \& Nivoli, F. (2008). Prevalence of exercise dependence and other behavioral addictions among clients of a Parisian fitness room. Comprehensive Psychiatry, 49(4), 353-358.

https://doi.org/10.1016/j.comppsych.2007.12.005

Lejoyeux, M., Guillot, C., Chalvin, F., Petit, A., \& Lequen, V. (2012). Exercise dependence among customers from a Parisian sport shop. Journal of Behavioral Addictions, 1(1), 28-34. https://doi.org/10.1556/JBA.1.2012.1.3

Lemeshow, A. R., Rimm, E. B., Hasin, D. S., Gearhardt, A. N., Flint, A. J., Field, A. E., \& Genkinger, J. M. (2018). Food and beverage consumption and food addiction among women in the Nurses' Health Studies. Appetite, 121, 186-197. https://doi.org/10.1016/j.appet.2017.10.038

Lichtenstein, M. B., \& Jensen, T. T. (2016). Exercise addiction in CrossFit: Prevalence and psychometric properties of the Exercise Addiction Inventory. Addictive Behaviors Reports, 3, 33-37. https://doi.org/10.1016/j.abrep.2016.02.002

Long, C. G., Blundell, J. E., \& Finlayson, G. (2015). A Systematic Review of the Application And Correlates of YFAS-Diagnosed Food Addiction' in Humans: Are Eating-Related Addictions' a Cause for Concern or Empty Concepts? Obesity Facts, 8(6), 386-401. https://doi.org/10.1159/000442403

Luppino, F. S., de Wit, L. M., Bouvy, P. F., Stijnen, T., Cuijpers, P., Penninx, B. W. J. H., \& Zitman, F. G. (2010). Overweight, Obesity, and Depression: A Systematic Review and Meta-analysis of Longitudinal Studies. Archives of General Psychiatry, 67(3), 220. https://doi.org/10.1001/archgenpsychiatry.2010.2

Lutz, R. (1996). Exploration positiver Eigenschaften - ein Beitrag zum verhaltensdiagnostischen Interview. In H. S. Reinecker \& F. H. Kanfer (Eds.), Verhaltenstherapie, Selbstregulation, 


\section{Teil 1 Einleitung}

Selbstmanagement: Frederick H. Kanfer zum 70. Geburtstag (p. 187). Göttingen: Hogrefe, Verl. für Psychologie.

Lutz, R. (2017). Genussfähigkeit Die „Kleine Schule des Genießens“ - eine euthyme Intervention lehrt uns Selbstfürsorge, (1/2017), 10.

Lutz, R. (2018). Was ist Genuss? Eine Standortbestimmung. VFED Fachmagazin, (1. Auflage 2018), $24-28$.

Lutz, R., \& Koppenhöfer, E. (Eds.). (1983). Kleine Schule des Genießens. In Genuss und Geniessen: zur Psychologie des genussvollen Erlebens und Handelns (pp. 112-125). Weinheim: Beltz.

Malik, S., Mitchell, J. E., Engel, S., Crosby, R., \& Wonderlich, S. (2014). Psychopathology in bariatric surgery candidates: A review of studies using structured diagnostic interviews. Comprehensive Psychiatry, 55(2), 248-259. https://doi.org/10.1016/j.comppsych.2013.08.021

Marcus, M. D., \& Wildes, J. E. (2009). Obesity: Is it a mental disorder? International Journal of Eating Disorders, 42(8), 739-753. https://doi.org/10.1002/eat.20725

Mason, B. J., \& Higley, A. E. (2012). Human Laboratory Models of Addiction. In K. D. Brownell \& M. S. Gold (Eds.), Food and Addiction (pp. 14-19). Oxford University Press. Retrieved from http://www.oxfordclinicalpsych.com/view/10.1093/med:psych/9780199738168.001.0001/m ed-9780199738168-chapter-2

Mason, B. J., Light, J. M., Escher, T., \& Drobes, D. J. (2008). Effect of positive and negative affective stimuli and beverage cues on measures of craving in non treatment-seeking alcoholics. Psychopharmacology, 200(1), 141-150. https://doi.org/10.1007/s00213-008-1192-x

McCabe, S. E., West, B. T., Morales, M., Cranford, J. A., \& Boyd, C. J. (2007). Does early onset of nonmedical use of prescription drugs predict subsequent prescription drug abuse and dependence? Results from a national study. Addiction, 102(12), 1920-1930. https://doi.org/10.1111/j.1360-0443.2007.02015.x

Meadows, A., Nolan, L. J., \& Higgs, S. (2017). Self-perceived food addiction: Prevalence, predictors, and prognosis. Appetite, 114, 282-298. https://doi.org/10.1016/j.appet.2017.03.051 


\section{Teil 1 Einleitung}

Mechoulam, R., \& Parker, L. A. (2013). The Endocannabinoid System and the Brain. Annual Review of Psychology, 64(1), 21-47. https://doi.org/10.1146/annurev-psych-113011-143739

Mensink, G. B. M., Schienkiewitz, A., Haftenberger, M., Lampert, T., Ziese, T., \& Scheidt-Nave, C. (2013). Übergewicht und Adipositas in Deutschland: Ergebnisse der Studie zur Gesundheit Erwachsener in Deutschland (DEGS1). Bundesgesundheitsblatt - Gesundheitsforschung Gesundheitsschutz, 56(5-6), 786-794. https://doi.org/10.1007/s00103-012-1656-3

Meule, A. (2014). Are Certain Foods Addictive? Frontiers in Psychiatry, 5(38), 1-3. https://doi.org/10.3389/fpsyt.2014.00038

Meule, A. (2015). Süchtig nach Essen: Substanzabhängigkeit oder Verhaltensproblem? Ernährung Im Fokus, 15(1-2), 12-19.

Meule A, Gearhardt AN (2014) Five years of the Yale Food Addiction Scale: taking stock and moving forward. Curr Addict Rep 1: 193-205

Meule, A., de Zwaan, M., \& Müller, A. (2017). Attentional and motor impulsivity interactively predict "food addiction" in obese individuals. Comprehensive Psychiatry, 72, 83-87. https://doi.org/10.1016/j.comppsych.2016.10.001

Meule, A., \& Gearhardt, A. N. (2014). Five years of the Yale Food Addiction Scale: Taking stock and moving forward. Current Addiction Reports, 1(3), 193-205. https://doi.org/10.1007/s40429014-0021-z

Meule, A., \& Kübler, A. (2012). The Translation of Substance Dependence Criteria to Food-Related Behaviors: Different Views and Interpretations. Frontiers in Psychiatry, 3(64), 1-2. https://doi.org/10.3389/fpsyt.2012.00064

Meule, A., Müller, A., Gearhardt, A. N., \& Blechert, J. (2016). German version of the Yale Food Addiction Scale 2.0: Prevalence and correlates of "food addiction" in students and obese individuals. Appetite, 1-8. https://doi.org/10.1016/j.appet.2016.10.003

Meule, A., von Rezori, V., \& Blechert, J. (2014). Food Addiction and Bulimia Nervosa: Food Addiction and Bulimia Nervosa. European Eating Disorders Review, 22(5), 331-337. https://doi.org/10.1002/erv.2306 


\section{Teil 1 Einleitung}

Mies, G. W., Treur, J. L., Larsen, J. K., Halberstadt, J., Pasman, J. A., \& Vink, J. M. (2017). The prevalence of food addiction in a large sample of adolescents and its association with addictive substances. Appetite, 118, 97-105. https://doi.org/10.1016/j.appet.2017.08.002

Mitchell, J. E., Pyle, R. L., \& Eckert, E. D. (1981). Frequency and duration of binge-eating episodes in patients with bulimia. American Journal of Psychiatry, 138(6), 835-836. https://doi.org/10.1176/ajp.138.6.835

Müller, A., Loeber, S., Söchtig, J., Te Wildt, B., \& De Zwaan, M. (2015). Risk for exercise dependence, eating disorder pathology, alcohol use disorder and addictive behaviors among clients of fitness centers. Journal of Behavioral Addictions, 4(4), 273-280. https://doi.org/10.1556/2006.4.2015.044

National Center for Health Statistics. (2016). ICD - Classification of Diseases, Functioning, and Disability [Internet]. Retrieved January 31, 2018, from http://apps.who.int/classifications/icd10/browse/2016/en

National Institute on Drug Abuse. (2011). Comorbidity: Addiction and Other Mental Illnesses. Retrieved August 12, 2016, from https://www.drugabuse.gov/publications/drugfacts/comorbidity-addiction-other-mentaldisorders

Nemeroff, C. B. (1996). The corticotropin-releasing factor (CRF) hypothesis of depression: new findings and new directions. Molecular Psychiatry, 1(4), 336-342.

NIDA. (2014). Drugs, Brains, and Behavior: The Science of Addiction. Retrieved from https://www.drugabuse.gov/publications/drugs-brains-behavior-science-addiction Noelle-Neumann, E., \& Köcher, R. (2002). Allensbacher Jahrbuch der Demoskopie 1984-1992. In Genuss und Gesundheit (p. 39). Köln: Kölner Univ.-Verl.

Nunes-Neto, P. R., Köhler, C. A., Schuch, F. B., Solmi, M., Quevedo, J., Maes, M., ... Carvalho, A. F. (2018). Food addiction: Prevalence, psychopathological correlates and associations with quality of life in a large sample. Journal of Psychiatric Research, 96, 145-152. https://doi.org/10.1016/j.jpsychires.2017.10.003 


\section{Teil 1 Einleitung}

Olszewski, P. K., Alsiö, J., Schiöth, H. B., \& Levine, A. S. (2011). Opioids as facilitators of feeding: Can any food be rewarding? Physiology \& Behavior, 104(1), 105-110.

https://doi.org/10.1016/j.physbeh.2011.04.033

Pelchat, M. L., Johnson, A., Chan, R., Valdez, J., \& Ragland, J. D. (2004). Images of desire: food-craving activation during fMRI. Neurolmage, 23(4), 1486-1493.

https://doi.org/10.1016/j.neuroimage.2004.08.023

Pescatello, L. S., \& American College of Sports Medicine (Eds.). (2014). ACSM's guidelines for exercise testing and prescription (9. ed). Philadelphia: Wolters Kluwer/Lippincott Williams \& Wilkins.

Potenza, M. N. (2014). Non-substance addictive behaviors in the context of DSM-5. Addictive Behaviors, 39(1), 1-2. https://doi.org/10.1016/j.addbeh.2013.09.004

Pudel, V., \& Westenhöfer, J. (1989). Fragebogen zum Eßverhalten (FEV). Hogrefe.

Puhl, R. M., \& Brownell, K. D. (2006). Confronting and Coping with Weight Stigma: An Investigation of Overweight and Obese Adults*. Obesity, 14(10), 1802-1815. https://doi.org/10.1038/oby.2006.208

Pursey, K. M., Davis, C., \& Burrows, T. L. (2017). Nutritional Aspects of Food Addiction. Current Addiction Reports, 4(2), 142-150. https://doi.org/10.1007/s40429-017-0139-x

Pursey, K., Stanwell, P., Gearhardt, A., Collins, C., \& Burrows, T. (2014). The Prevalence of Food Addiction as Assessed by the Yale Food Addiction Scale: A Systematic Review. Nutrients, 6(10), 4552-4590. https://doi.org/10.3390/nu6104552

Rada, P., Avena, N. M., \& Hoebel, B. G. (2005). Daily bingeing on sugar repeatedly releases dopamine in the accumbens shell. Neuroscience, 134(3), 737-744. https://doi.org/10.1016/j.neuroscience.2005.04.043

Rainey, J. C., Furman, C. R., \& Gearhardt, A. N. (2018). Food addiction among sexual minorities. Appetite, 120, 16-22. https://doi.org/10.1016/j.appet.2017.08.019

Randolph, T. G. (1956). The descriptive features of food addiction; addictive eating and drinking. Quarterly Journal of Studies on Alcohol, 17(2), 198-224. 


\section{Teil 1 Einleitung}

Rebscher H, Marschall J, Hildebrandt-Heene S et al. (2016) Schwerpunkt: Gender und Gesundheit

Band 13. https://de.statista.com/themen/1318/psychische-erkrankungen/. Accessed 05 Sep 2016

Ricca, V., Castellini, G., Lo Sauro, C., Ravaldi, C., Lapi, F., Mannucci, E., ... Faravelli, C. (2009). Correlations between binge eating and emotional eating in a sample of overweight subjects. Appetite, 53(3), 418-421. https://doi.org/10.1016/j.appet.2009.07.008

Rippe, J. M. (2014). Lifestyle Medicine: The Importance of Firm Grounding on Evidence. American Journal of Lifestyle Medicine, 8(5), 306-312. https://doi.org/10.1177/1559827613520527

Röthig, P., \& Prohl, R. (Eds.). (2003). Sportwissenschaftliches Lexikon (7., völlig neu bearb. Aufl). Schorndorf: Hofmann.

Rumpf, H.-J., \& Mann, K. (2017). Die Verhaltenssüchte in der ICD-11: Ein Update: Behavioral Addictions in ICD-11: An Update. SUCHT, 63(6), 305-306. https://doi.org/10.1024/0939$5911 / a 000510$

Saunders, R. (2004). “Grazing”: A High-Risk Behavior. Obesity Surgery, 14(1), 98-102. https://doi.org/10.1381/096089204772787374

Schag, K., Mack, I., Giel, K., Ölschläger, S., Skoda, E.-M., von Feilitzsch, M., ... Teufel, M. (2016). The Impact of Impulsivity on Weight Loss Four Years after Bariatric Surgery. Nutrients, 8(11), 721. https://doi.org/10.3390/nu8110721

Schag, K., Schönleber, J., Teufel, M., Zipfel, S., \& Giel, K. E. (2013). Food-related impulsivity in obesity and Binge Eating Disorder - a systematic review: Food-related impulsivity. Obesity Reviews, 14(6), 477-495. https://doi.org/10.1111/obr.12017

Schienle, A., Schäfer, A., Hermann, A., \& Vaitl, D. (2009). Binge-Eating Disorder: Reward Sensitivity and Brain Activation to Images of Food. Biological Psychiatry, 65(8), 654-661. https://doi.org/10.1016/j.biopsych.2008.09.028

Schipfer, M. (2015). Sportbindung und Sportsucht im Ausdauersport: Theorie - Diagnostik - Empirie. Hamburg: Kovač. 


\section{Teil 1 Einleitung}

Schneider, M. (2004). Langfristige Folgen des chronischen Cannabiskonsums. Sucht, (5). https://doi.org/10.1463/2004.05.04

Schulte, E. M., Avena, N. M., \& Gearhardt, A. N. (2015). Which Foods May Be Addictive? The Roles of Processing, Fat Content, and Glycemic Load. PLOS ONE, 10(2), e0117959. https://doi.org/10.1371/journal.pone.0117959

Schulte, E. M., \& Gearhardt, A. N. (2017). Associations of Food Addiction in a Sample Recruited to Be Nationally Representative of the United States: Food Addiction in the United States. European Eating Disorders Review. https://doi.org/10.1002/erv.2575

Schweppe, R. (2014). Mit Achtsamkeit zum Wunschgewicht. UGBforum, 1/14, 13-16.

Sinha, R., Fox, H., Hong, K.-I., Sofuoglu, M., Morgan, P. T., \& Bergquist, K. T. (2007). Sex steroid hormones, stress response, and drug craving in cocaine-dependent women: Implications for relapse susceptibility. Experimental and Clinical Psychopharmacology, 15(5), 445-452. https://doi.org/10.1037/1064-1297.15.5.445

Smith, D. G., \& Robbins, T. W. (2013). The Neurobiological Underpinnings of Obesity and Binge Eating: A Rationale for Adopting the Food Addiction Model. Biological Psychiatry, 73(9), 804810. https://doi.org/10.1016/j.biopsych.2012.08.026

Spence, C. (2012). Auditory contributions to flavour perception and feeding behaviour. Physiology \& Behavior, 107(4), 505-515. https://doi.org/10.1016/j.physbeh.2012.04.022

Stangl, Werner. (2016). Sucht \& Drogen, Lernen. [werner stangl]s arbeitsblätter. Retrieved June 12, 2016, from http://arbeitsblaetter.stangl-taller.at/SUCHT/

Stevenson, A., \& Pearsall, J. (Eds.). (2010). Oxford dictionary of English (3. ed). Oxford: Oxford Univ. Press.

Stice, E., Figlewicz, D. P., Gosnell, B. A., Levine, A. S., \& Pratt, W. E. (2013). The contribution of brain reward circuits to the obesity epidemic. Neuroscience \& Biobehavioral Reviews, 37(9), 20472058. https://doi.org/10.1016/j.neubiorev.2012.12.001 


\section{Teil 1 Einleitung}

Stöber, J. (2004). Skalendokumentation "Perfektionismus im Sport"/ Joachim Stöber ... Martin-LutherUniversität, Institut für Pädagogik. (Institut für Pädagogik, Ed.). Halle (Saale): Martin-LutherUniversität Halle-Wittenberg, Institut für Pädagogik.

Stoeber, J. (2011). The dual nature of perfectionism in sports: relationships with emotion, motivation, and performance. International Review of Sport and Exercise Psychology, 4(2), 128-145. https://doi.org/10.1080/1750984X.2011.604789

Stunkard, A. J., \& Messick, S. (1985). THE THREE-FACTOR EATING QUESTIONNAIRE TO MEASURE DIETARY RESTRAINT, DISINHIBITION AND HUNGER. Journal of PsychosomolicReseorch, 29(1), 71-83.

Substance Abuse and Mental Health Services Administration. (2013). Results from the 2012 National Survey on Drug Use and Health: Summary of National Findings. (NSDUH Series H-46, HHS Publication No. (SMA) 13-4795) (p. 178). Rockville, MD. Retrieved from https://www.samhsa.gov/data/sites/default/files/NSDUHresults2012/NSDUHresults2012.pdf

Sundgot-Borgen, J., \& Torstveit, M. K. (2004). Prevalence of Eating Disorders in Elite Athletes Is Higher Than in the General Population: Clinical Journal of Sport Medicine, 14(1), 25-32. https://doi.org/10.1097/00042752-200401000-00005

Sussman. (2017). Substance and behavioral addictions: concepts, causes, and cures.

Sussman, S., Lisha, N., \& Griffiths, M. (2011). Prevalence of the Addictions: A Problem of the Majority or the Minority? Evaluation \& the Health Professions, 34(1), 3-56.

https://doi.org/10.1177/0163278710380124

Sussman, S., \& Sussman, A. N. (2011). Considering the Definition of Addiction. International Journal of Environmental Research and Public Health, 8(12), 4025-4038. https://doi.org/10.3390/ijerph8104025

Swarna Nantha, Y., Abd Patah, N. A., \& Ponnusamy Pillai, M. (2016). Preliminary validation of the Malay Yale Food Addiction Scale: Factor structure and item analysis in an obese population. Clinical Nutrition ESPEN, 16, 42-47. https://doi.org/10.1016/j.clnesp.2016.08.001 


\section{Teil 1 Einleitung}

Tang, D. W., Fellows, L. K., Small, D. M., \& Dagher, A. (2012). Food and drug cues activate similar brain regions: A meta-analysis of functional MRI studies. Physiology \& Behavior, 106(3), 317324. https://doi.org/10.1016/j.physbeh.2012.03.009

Tuomisto, T., Hetherington, M. M., Morris, M. F., Tuomisto, M. T., Turjanmaa, V., \& Lappalainen, R. (1999). Psychological and physiological characteristics of sweet food "addiction." The International Journal of Eating Disorders, 25(2), 169-175.

Tuomisto, T., Lappalainen, R., Heterington, M., Morris, M.-F., \& Tuomisto, M. T. (1997). Affective, physiological and overt behavioral responses to chocolate in self-identified "chocolate addicts." International Journal of Psychophysiology, 25(1), 38-39. https://doi.org/10.1016/S0167-8760(97)85440-2

Uhl, G. R., Liu, Q.-R., \& Naiman, D. (2002). Substance abuse vulnerability loci: converging genome scanning data. Trends in Genetics: TIG, 18(8), 420-425.

Vanderlinden, J., Dalle Grave, R., Vandereycken, W., \& Noorduin, C. (2001). Which factors do provoke binge-eating? An exploratory study in female students. Eating Behaviors, 2(1), 79-83.

Veale, D. (1995). Does Primary Exercise Dependence really exist? In J. Annett, B. Cripps, \& H. Steinberg (Eds.), Exercise Addiction: Motivation for participation in sport and exercise : Proceedings of British Psychology, Sport and Exercise Psychology Section. ed. (pp. 71-75). British Psychological Society.

Veenstra, E. M., \& de Jong, P. J. (2010). Restrained eaters show enhanced automatic approach tendencies towards food. Appetite, 55(1), 30-36. https://doi.org/10.1016/j.appet.2010.03.007

Volkow, N. D. (2010). Comorbidity: Addiction and Other Mental Disorders. Retrieved August 12, 2016, from https://d14rmgtrwzf5a.cloudfront.net/sites/default/files/rrcomorbidity.pdf

Volkow, N. D., Koob, G. F., \& McLellan, A. T. (2016). Neurobiologic Advances from the Brain Disease Model of Addiction. New England Journal of Medicine, 374(4), 363-371.

https://doi.org/10.1056/NEJMra1511480 


\section{Teil 1 Einleitung}

Volkow, N. D., \& O'Brien, C. P. (2007). Issues for DSM-V: Should Obesity Be Included as a Brain Disorder? American Journal of Psychiatry, 164(5), 708-710. https://doi.org/10.1176/ajp.2007.164.5.708

Volkow, N. D., \& Wise, R. A. (2005). How can drug addiction help us understand obesity? Nature Neuroscience, 8(5), 555-560. https://doi.org/10.1038/nn1452

Volkow, Wang, G.-J., Tomasi, D., \& Baler, R. D. (2013a). Obesity and addiction: neurobiological overlaps: Overlaps between drug and food addiction. Obesity Reviews, 14(1), 2-18. https://doi.org/10.1111/j.1467-789X.2012.01031.x

Volkow, Wang, G.-J., Tomasi, D., \& Baler, R. D. (2013b). The Addictive Dimensionality of Obesity. Biological Psychiatry, 73(9), 811-818. https://doi.org/10.1016/j.biopsych.2012.12.020

Wagner, F. (2002). From First Drug Use to Drug Dependence Developmental Periods of Risk for Dependence upon Marijuana, Cocaine, and Alcohol. Neuropsychopharmacology, 26(4), 479488. https://doi.org/10.1016/S0893-133X(01)00367-0

Wang, G.-J., Volkow, N. D., Logan, J., Pappas, N. R., Wong, C. T., Zhu, W., ... Fowler, J. S. (2001). Brain dopamine and obesity. The Lancet, 357(9253), 354-357. https://doi.org/10.1016/S01406736(00)03643-6

Wang, G.-J., Volkow, N. D., Thanos, P. K., \& Fowler, J. S. (2009). Imaging of Brain Dopamine Pathways: Implications for Understanding Obesity. Journal of Addiction Medicine, 3(1), 8-18. https://doi.org/10.1097/ADM.0b013e31819a86f7

Ware, J. E., \& Sherbourne, C. D. (1992). The MOS 36-item short-form health survey (SF-36). I. Conceptual framework and item selection. Medical Care, 30(6), 473-483.

Weiner, B., \& White, W. (2007). The Journal of Inebriety (1876-1914): history, topical analysis, and photographic images. Addiction, 102(1), 15-23. https://doi.org/10.1111/j.13600443.2006.01680.x

Westenhoefer, J., Stunkard, A. J., \& Pudel, V. (1999). Validation of the flexible and rigid control dimensions of dietary restraint. The International Journal of Eating Disorders, 26(1), 53-64. 


\section{Teil 1 Einleitung}

Whiteford, H. A., Degenhardt, L., Rehm, J., Baxter, A. J., Ferrari, A. J., Erskine, H. E., ... Vos, T. (2013). Global burden of disease attributable to mental and substance use disorders: findings from the Global Burden of Disease Study 2010. The Lancet, 382(9904), 1575-1586. https://doi.org/10.1016/S0140-6736(13)61611-6

Williams, D. M., \& Marcus, B. H. (2012). Exercise Addiction and Aversion. In K. D. Brownell \& M. S. Gold (Eds.), Food and Addiction (pp. 336-341). Oxford University Press. Retrieved from http://www.oxfordclinicalpsych.com/view/10.1093/med:psych/9780199738168.001.0001/m ed-9780199738168-chapter-50

Wise, R. A., \& Rompre, P. P. (1989). Brain Dopamine and Reward. Annual Review of Psychology, 40(1), 191-225. https://doi.org/10.1146/annurev.ps.40.020189.001203

World Health Organisation [WHO]. (2014). Basic documents. Forty-eighth edition. Geneva: World Health Organization.

World Health Organization. (2014). ALCOHOL CONSUMPTION: LEVELS AND PATTERNS - Germany. Retrieved from http://www.who.int/substance_abuse/publications/global_alcohol_report/profiles/deu.pdf

World Health Organization (WHO). (2017, October). Obesity and overweight Fact sheet No. 311 Updated October 2017. Retrieved from http://www.who.int/mediacentre/factsheets/fs311/en/

World Health Organization (WHO). (2018, January 8). ICD-11 Beta Draft (Mortality and Morbidity Statistics). Retrieved from https://icd.who.int/dev11/Im/en\#/http\%3a\%2f\%2fid.who.int\%2ficd\%2fentity\%2f1448597234

Youngman, J. D. (2007). Risk for Exercise Addiction: A Comparison of Triathletes Training for Sprint-, Olympic-, Half-Ironman-, and Ironman-distance Triathlons (Open Access Dissertations). Retrieved from http://scholarlyrepository.miami.edu/oa_dissertations/12

Zeeck, A., Leonhart, R., Mosebach, N., Schlegel, S., Linster, H. W., \& Hartmann, A. (2013). Psychopathologische Aspekte von Sport: Eine deutsche Adaptation der „Exercise 


\section{Teil 1 Einleitung}

Dependence Scale“ (EDS-R). Zeitschrift für Sportpsychologie, 20(3), 94-106.

https://doi.org/10.1026/1612-5010/a000099

Zeeck, A., \& Schlegel, S. (2012). Sportliche Aktivität und Essstörungen. In R. Fuchs \& W. Schlicht, Seelische Gesundheit und sportliche Aktivität (pp. 229-250). S.I.: Hogrefe Verlag.

Ziauddeen, H., Alonso-Alonso, M., Hill, J. O., Kelley, M., \& Khan, N. A. (2015). Obesity and the Neurocognitive Basis of Food Reward and the Control of Intake. Advances in Nutrition: An International Review Journal, 6(4), 474-486. https://doi.org/10.3945/an.115.008268

Ziauddeen, H., Farooqi, I. S., \& Fletcher, P. C. (2012a). Food addiction: is there a baby in the bathwater? Nature Reviews Neuroscience, 13(7), 514-514. https://doi.org/10.1038/nrn3212c2

Ziauddeen, H., Farooqi, I. S., \& Fletcher, P. C. (2012b). Obesity and the brain: how convincing is the addiction model? Nature Reviews Neuroscience, 13, 279-286.

https://doi.org/10.1038/nrn3212

Ziauddeen, H., \& Fletcher, P. C. (2013). Is food addiction a valid and useful concept?: Food addiction: valid and useful? Obesity Reviews, 14(1), 19-28. https://doi.org/10.1111/j.1467-

789X.2012.01046.x 


\section{Teil 2 - Eigene Publikationen zu Food Addiction}

Den zweiten Teil der dreigeteilten Dissertationsschrift bilden die eigenen Publikationen zu Food Addiction. In diesem Teil finden sich fünf Publikationen, die konzipiert wurden, um zu neuen Erkenntnissen der Food Addiction-Forschung beizutragen. Die Artikel zeigen erste weltweite Daten zur Prävalenz von Food Addiction in einer bevölkerungsrepräsentativen Stichprobe. Zudem wurden beeinflussende Variablen auf Food Addiction ermittelt. Alle Publikationen - bis auf Kapitel fünf - sind bereits veröffentlicht und publiziert und stellen damit den Hauptteil vorliegender kumulativer Dissertationsarbeit dar.

\section{Prevalence of Food Addiction as Measured with the Yale Food Addiction Scale 2.0 in a Representative German Sample and Its Association with Sex, Age and Weight Categories}

Der bereits publizierte Originalartikel ist mit Genehmigung des Verlags im Anhang zu finden. 
4. „Food Addiction“, gezügeltes Essverhalten, mentaler Gesundheitsstatus und Heißhungersymptome bei morbider Adipositas

English version:

Relationship between 'Food Addiction', restrained eating behavior, mental health status and score of binge eating in a morbidly obese German sample

Der bereits publizierte Originalartikel ist mit Genehmigung des Verlags im Anhang zu finden. 


\section{Food Addiction, exercise dependence and perfectionism in amateur athletes}

\subsection{Keywords}

food addiction; Yale Food Addiction Scale 2.0; exercise dependence; perfectionism; amateur athletes

\subsection{Abstract}

\section{Background and aims}

Food addiction is a conceptualization to describe when eating behavior may closely resemble an addiction. Exercise dependence may co-occur with eating disorders and could be a problem in eating-related pathologies. Perfectionism has been implicated in the etiology of both, food addiction and exercise dependence. Athletes represent a population that is potentially at risk for exercise dependence and eating problems and often show high values of perfectionism. Current study aimed to evaluate prevalence and correlations of food addiction, exercise dependence and perfectionism, and predictors of food addiction in a sample of amateur athletes.

Methods

A total of 1204 German speaking amateur athletes filled in the Yale Food Addiction Scale 2.0, the Questionnaire to diagnose exercise-dependence in endurance sports and the multidimensional inventory of perfectionism in sport, via an online data collection website. SPSS 24 was used for descriptive analyses, Mann-Whitney-Utests, chi-squared tests and binary logistic regressions.

Results

Prevalence of food addiction was $6.3 \%$ and of a risk of exercise dependence 30.6 $\%$. Correlations between the three variables were found. Concerns of imperfection and risk of exercise dependence predict food addiction. 


\section{Discussion and Conclusion}

A significant part of German amateur athletes is at risk for food addiction and exercise dependence and in need of proper treatment. However, the majority is not. Further research is needed, especially on the overlap/distinction of food addiction and eating disorders.

\subsection{INTRODUCTION}

Food addiction is a relatively recent conceptualization to describe when eating behavior may closely resemble an addiction. Specifically, certain addiction-like patterns of eating may in-part help explain the exponential rise in obesity rates (Gearhardt, Corbin, \& Brownell, 2009). Furthermore, defining specific patterns of eating as a food addiction may offer new insights that can inform the development of therapeutic interventions for overweight and obesity. Thus, food addiction posits that highly processed foods, with added fats and/or refined carbohydrates, (e.g., pizza, chocolate, biscuits) may be capable of triggering an addictive-like response in some individuals on a substance-based perspective, whereby an interaction with individual susceptibilities plays an important role (Gearhardt et al., 2011; Schulte, Avena, \& Gearhardt, 2015). Nevertheless, the concept of food addiction remains controversial with regards to precise definitions and evidence from animal research that further confuses significance of a food addiction diagnosis (Meule \& Kübler, 2012; Ziauddeen, Farooqi, \& Fletcher, 2012b, 2012a; Ziauddeen \& Fletcher, 2013). For example, there are uncertainties in neurobiological research and inconsistencies in human research on food addiction (Ziauddeen \& Fletcher, 2013).

Approximately 5-10\% of individuals in community-based samples exhibit symptoms of food addiction; with higher prevalence rates among obese patients (15$25 \%$ ) and still higher values in patients with morbid obesity, binge eating disorder (BED) or Bulimia nervosa (BN; Meule \& Gearhardt, 2014). Prevalence rate of food addiction representative for the German population was $6.9 \%$ in 2016 (Hauck, Weiß, Schulte, Meule, \& Ellrott, 2017b) The relationship among weight status and food addiction is complex as, beside the overweight and obese individuals suffering from food addiction, also a substantial portion of underweight and normal weight subjects meet food addiction criteria (Corwin \& Hayes, 2014). Thus, further examination of 
such individuals is needed. At this time it is unclear whether food addiction is an independent disorder or part of an already existing disorder (Hauck, Weiß, \& Ellrott, 2016).

There is considerable controversy regarding if behavioral addictions or addiction-like syndromes are independent psychiatric disorders, symptoms of other extant disorders, or simply expressions of underlying issues related to impulsivity or compulsivity (Cook, Hausenblas, \& Freimuth, 2014; Sussman, Lisha, \& Griffiths, 2011; Sussman, 2017). This is especially confused with behaviors such as eating and exercise. For example, recent research has suggested exercise dependence may co-occur with several other behavioral addictions and eating disorders (Cook et al., 2014; Lejoyeux, Avril, Richoux, Embouazza, \& Nivoli, 2008; Lejoyeux, Guillot, Chalvin, Petit, \& Lequen, 2012; Müller, Loeber, Söchtig, Te Wildt, \& De Zwaan, 2015). In people with eating disorders, prevalence rates of exercise dependence between 40-70 \% have been observed (Zeeck et al., 2013). Estimates for Germany assume a manifest disorder for one in 1.000 and need of treatment for one in 10.000 (Breuer \& Kleinert, 2009). Taken together with the aforementioned ambiguity concerning the distinction among eating disorders and food addiction, such prevalence rates lead to the possibility that exercise dependence could be a significant problem in individuals' eating-related pathologies. The relationship among food addiction symptoms and exercise may be further confused by deviations from "normal" patterns of eating that are often used therapeutically in certain populations. For example, athletes require simple carbohydrates such as the highly processed foods commonly consumed by individuals with food addiction (Gearhardt et al., 2011; Schulte et al., 2015) to fuel exercise and even increase athletic performance. This further confuses the nature of over exercise and abnormal eating patterns because the end goal is not psychopathological in nature (e.g., internalized), but an obtainment of performance goals (e.g., externalized). Thus, the elevated rates of exercise dependence in athletes (Cook et al., 2013, 2014), previously observed comorbidity of both exercise dependence and food addiction within individuals with eating disorders (Sussman, 2017), and observation of similar types of food consumed by individuals with food addiction and exercise depended tacitly suggests that athletes may be an interesting population to examine the co-occurrence of behavioral addictions. 
Athletes represent a population that is potentially at-risk for exercise dependence and eating problems (Sundgot-Borgen \& Torstveit, 2004), although. The higher risk may be exacerbated by unique challenges and potential problems with eating, training, and psychological factors. For example, perfectionism has been implicated in the etiology of both eating disorders (Bardone-Cone et al., 2007; Forsberg \& Lock, 2006), exercise dependence (Costa, Hausenblas, Oliva, Cuzzocrea, \& Larcan, 2016; Hall, Hill, Appleton, \& Kozub, 2009; Hill, Robson, \& Stamp, 2015), and also plays an important role in sport performance in athletes with participation in high level competitions. Despite everything, little research is available on prevalence rates of food addiction, exercise dependence and values of perfectionism in amateur athletes, yet. Furthermore little is known on associations between perfectionism, exercise dependence and food addiction. Given the extant literature that suggests perfectionism may play a key etiological role in both eating and exercise-related disorders, research is needed to further elucidate such potential relationships as they may relate to food addiction.

The purpose of our study was to examine prevalence rates of food addiction, exercise dependence and the values of perfectionism in a sample of amateur endurance athletes. Furthermore the relationship among perfectionism, food addiction and exercise dependence was investigated.

We hypothesized that (1) prevalence rates of food addiction and exercise dependence are higher in amateur athletes than in the general population $(6.9 \%$ food addiction, 1:1000 exercise dependence; Breuer \& Kleinert, 2009; Hauck et al., 2017) because athletes are potentially at-risk for eating problems and exercise dependence (Sundgot-Borgen \& Torstveit, 2004). We hypothesized that (2) correlations between food addiction, exercise dependence and perfectionism exist (Cook et al., 2014; Costa et al., 2016; Sussman, 2017). We further hypothesized that (3) perfectionism and exercise dependence predict food addiction. 


\subsection{METHODS}

\subsubsection{Participants}

A total of 1204 men and women completed on a voluntary basis an online questionnaire through a secure online data collection website (e.g., https://www.soscisurvey.de). They were recruited via an online link which was distributed via email among sports associations throughout Germany (especially Bavaria, Baden-Wuerttemberg, Lower Saxony and Hesse), via German Facebookgroups for athletes (e.g. Runner's World Deutschland, Challenge Roth, Achim Achilles) and via word-of-mouth recommendations, reposts and forwarding among the participants. Participation was not limited, despite for an age of at least 18 years; consequently nearly everybody could participate in the study. Nevertheless mostly German speaking exercise-oriented adults rolled into sports associations or specific Facebook-groups were addressed to.

According to the ACSM's recommendations, adults should engage in at least 150 minutes of moderate-intensity exercise every week (Garber et al., 2011). Schipfer assumes that people who engage in at least four hours exercise per week embedded exercise in their everyday life (Schipfer, 2015). All participants who selfreported less than four hours of physical exercise per week and datasheets with missing values were excluded, resulting in a sample of 1025 participants, further referred to as amateur athletes. These 1025 people are the participants in the study. No further restrictions, e.g. type of sports, were applied. Anthropometric data of the sample are listed in Tabelle 8 . More than $80 \%$ of the participants self-reported regular participations in contests, which stands for achievement-orientation. Overall mean BMI was $23 \mathrm{~kg} / \mathrm{m}^{2}$ (Tabelle 8). 
Tabelle 8: Continuous variables of study population $(n=1025)$

\begin{tabular}{|c|c|c|}
\hline Variable & \multicolumn{2}{|c|}{$\begin{array}{l}\text { Mean, median, standard deviation and Min, Max } \\
\text { of study variables }\end{array}$} \\
\hline Sex & \multicolumn{2}{|l|}{$43.5 \%$ male, $56.5 \%$ female } \\
\hline Age (years) & \multicolumn{2}{|c|}{$36.4(\tilde{x}=35.0 ; \mathrm{SD}=11 ; 18-78)$} \\
\hline \multirow{6}{*}{$\mathrm{BMI}\left(\mathrm{kg} / \mathrm{m}^{2}\right)$} & \multicolumn{2}{|c|}{$22.83(\tilde{x}=22.32 ; \mathrm{SD}=3.06 ; 14.71-45.78)$} \\
\hline & BMI category & Amount (in \%) \\
\hline & $\begin{array}{l}\text { Underweight } \quad(<18.5 \\
\left.\mathrm{kg} / \mathrm{m}^{2}\right)\end{array}$ & 3.9 \\
\hline & $\begin{array}{l}\text { Normal weight }(18.5- \\
\left.24.9 \mathrm{~kg} / \mathrm{m}^{2}\right)\end{array}$ & 77.5 \\
\hline & $\begin{array}{l}\text { Overweight }(25-29.9 \\
\left.\mathrm{kg} / \mathrm{m}^{2}\right)\end{array}$ & 16.0 \\
\hline & Obese $\left(>30 \mathrm{~kg} / \mathrm{m}^{2}\right)$ & 2.6 \\
\hline Years of practiced exercise (years) & \multicolumn{2}{|c|}{$11.0(\tilde{x}=8.0 ; \mathrm{SD}=9.4 ; 1-70)$} \\
\hline Hours of exercise per week (hours) & \multicolumn{2}{|c|}{$7.9(\tilde{x}=7.0 ; \mathrm{SD}=3.7 ; 4-28)$} \\
\hline Importance of exercise & \multicolumn{2}{|c|}{$7.8(\tilde{x}=8.0 ; \mathrm{SD}=1.2 ; 1-10)$} \\
\hline Participation in competition & \multicolumn{2}{|l|}{$81.7 \%$ yes, $18.3 \%$ no } \\
\hline Frequencies of practiced type of sport & \multicolumn{2}{|c|}{$\begin{array}{l}60.8 \% \text { Running, } 9.2 \text { \% Triathlon, } 8.3 \% \text { Cycling, } \\
7.1 \% \text { Fitness, } 5.2 \% \text { Team Sports, } 9.4 \% \text { Other }\end{array}$} \\
\hline
\end{tabular}

\subsubsection{Measures}

The online-survey contained the three following questionnaires which were used in their German versions:

Yale food addiction scale 2.0 (YFAS 2.0)

The Yale Food Addiction Scale 2.0 (Gearhardt et al., 2016) applies the Diagnostic and Statistical Manual of Mental Disorders $\left(5^{\text {th }}\right.$ version, DSM-5; American Psychiatric Association, 2013) criteria for substance-related and addictive disorders (SRAD; e.g., tolerance, withdrawal, etc.) to the consumption of foods. It is the only validated instrument to operationalize addictive-like eating behavior in humans. The YFAS 2.0 is a 35-item self-report questionnaire and measures individual meets on a continuous scale ranging from 0-11. The threshold for an YFAS 2.0 food addiction is met by endorsing two or more DSM-5 SRAD criteria, plus showing clinically significant distress or impairment. Within the validation study by Gearhardt et al., the YFAS 2.0 
has demonstrated internal reliability $(\alpha=.90)$ and convergent validity with other measures of problematic eating (Gearhardt et al., 2016). The YFAS has been translated to German (Meule et al., 2016).

Questionnaire to diagnose exercise-dependence in endurance sports (FESA)

The questionnaire to Diagnose Exercise-Dependence in Endurance Sports (Schipfer, 2015) measures exercise dependence via 16 items on a seven-point Likert scale. It includes the following five factors: expected positive consequences, interference with social life, health, withdrawal symptoms and exercise as a possibility to compensate for psychological problems. The factors "interference with social life" and "exercise as a possibility to compensate psychological problems" correlate with perfectionistic concerns and striving for perfectionism (Schipfer, 2015). The FESA is a new tool to screen and categorize athletes into three groups: committed to exercise, focused on exercise and at risk of exercise dependence.

\section{Multidimensional inventory of perfectionism in sport (MIPS)}

The multidimensional inventory of perfectionism in sport (Stöber, 2004) is a 20-item questionnaire with four subscales: striving for perfectionism in training/competition and perfectionistic concerns in training/competition. Each of the four subscales consists of five items on a six-point Likert-scale. The questionnaire is validated for use in training and competition situations. The current study uses the ten questions focusing on perfectionism in training in order to specifically focus on the training situations which are more relevant in everyday life.

\subsubsection{Procedure}

All study measures were completed through a secure online data collection website (e.g., https://www.soscisurvey.de). The webpage reached 10,756 clicks within the month of the survey (30.09.2016-30.10.2016). A total of 1204 people completed the full questionnaire in this period of time, resulting in a sample of 1025 contestants who exercise at least four hours per week and were referred to as amateur athletes. 


\subsubsection{Statistical analysis}

Data were analyzed using SPSS 24. Descriptive analyses include mean, median, standard deviation, minimum and maximum of study variables. In order to test significant differences between individuals with and without food addiction, nonparametric Mann-Whitney- $U$ tests were used as the data were not normally distributed and in each case two independent samples were studied. Correlations between food addiction and exercise dependence were assessed via chi-squared tests as both variables are binary and between food addiction and perfectionism via Mann-Whitney-U-test, as perfectionism is a continuous variable. In order to test the relationship between the binary dependent variable food addiction and the independent variables exercise dependence and perfectionism (= predictors), a binary logistic regression analysis was conducted.

This analytic approach allowed us to evaluate

1) the prevalence rate and frequency of YFAS 2.0 food addiction symptoms, the prevalence rate of a risk for exercise dependence,

2) the correlations between 'food addiction', exercise dependence and perfectionism,

3) and the predictors of food addiction in German amateur athletes.

\subsubsection{Ethics}

The online study procedures were carried out in accordance with the ethical principles of the Declaration of Helsinki. Ethics approval was obtained from the institutional review board of the ethics committee of the Faculty of Medicine of the University of Goettingen. All subjects were informed about the study and all provided informed consent. 


\subsection{RESULTS}

5.5.1 Prevalence and frequency of YFAS 2.0 food addiction symptoms

Prevalence of food addiction was $6.3 \%(n=64)$ with mean number of symptoms of 0.93 (Tabelle 9). All of the eleven YFAS 2.0 subscales significantly differed between people with and without food addiction, with medium effect each (Mann-Whitney Utests, $p=.000$ ). Tabelle 9 illustrates the percentage of individuals meeting the criteria of food addiction symptoms in people with and without food addiction.

Tabelle 9: Frequencies of YFAS 2.0 food addiction symptoms fulfilled

\begin{tabular}{|l|l|l|}
\hline YFAS 2.0 food addiction symptom & $\begin{array}{l}\text { Overall sample }(\%) \\
(\mathrm{N}=1025)^{\#}\end{array}$ & $\begin{array}{l}\text { People with FA (\%) } \\
(\mathrm{n}=64)^{\mathrm{a}}\left(\mathrm{d}_{\text {Cohen }}\right)\end{array}$ \\
\hline Loss of control (amount) & 19.6 & $87.9(1.75)$ \\
\hline Unsuccessful cut-down (attempts) & 12.4 & $68.8(2.31)$ \\
\hline Time spent & 6.3 & $51.6(2.25)$ \\
\hline Activities given up & 7.1 & $54.7(2.24)$ \\
\hline Aversive Consequences & 6.1 & $60.9(3.01)$ \\
\hline Tolerance & 5.4 & $57.8(3.10)$ \\
\hline Withdrawal & 12.0 & $62.5(1.81)$ \\
\hline Interpersonal Problems & 8.6 & $64.1(2.46)$ \\
\hline $\begin{array}{l}\text { Impaired daily functioning } \\
\text { (obligations) }\end{array}$ & 6.5 & $57.8(2.62)$ \\
\hline Dangerous Situations & 2.0 & $28.1(2.23)$ \\
\hline Craving & 6.6 & $40.6(1.60)$ \\
\hline Clin. Sign. Impairment & 7.6 & $100.0(8.49)$ \\
\hline $\begin{array}{l}\text { YFAS 2.0 Food Addiction } \\
\text { (combined mild + moderate + severe) }\end{array}$ & 6.2 & $\begin{array}{l}6.27 \\
(\mathrm{SD}=2.87 ; 2-11)\end{array}$ \\
\hline YFAS 2.0 Symptom count & $\mathrm{SD}=1.98 ; 0-11)$ & $(\tilde{x}=0.0 ;$ \\
\hline all symptoms significantly differ between people with and without food addiction; $p=.000$
\end{tabular}




\subsubsection{Prevalence for a risk for exercise dependence (FESA)}

Prevalence for a risk for exercise dependence was $30.6 \%$ (measured by FESA, $\mathrm{n}=$ $314,39.8 \%$ male, age $\bar{x}=34.1$ years $S D=10.4, B M I \bar{x}=22.5 \mathrm{~kg} / \mathrm{m}^{2} S D=2.9$, years of practiced exercise $\bar{x}=10.6$ years $S D=8.9$, hours of exercise per week $\bar{x}=8.4$ hours $S D=3.8$, importance of exercise (scale 1-10) $\bar{x}=8.2 S D=1.1$, frequencies of practiced type of sport: $59.2 \%$ running, $11.5 \%$ triathlon, $8.3 \%$ cycling, $21 \%$ other, food addiction rate $10.8 \%$, mean number of food addiction symptoms 1.40 (SD = 2.4)). Prevalence for both, a risk for secondary exercise dependence and an YFAS 2.0 food addiction, was $0.3 \%(n=34,82.4 \%$ female, age $\bar{x}=28.5$ years $S D=8.3$, BMI $\bar{x}=23.1 \mathrm{~kg} / \mathrm{m}^{2} \mathrm{SD}=4.0$, years of practiced exercise $\bar{x}=10.3$ years $S D=8.1$, hours of exercise per week $\bar{x}=7.9$ hours $S D=3.3$, importance of exercise (scale 110) $\bar{x}=8.2 \mathrm{SD}=1.0$, frequencies of practiced type of sport: $58.8 \%$ running $11.8 \%$ triathlon, $8.8 \%$ cycling, $20.6 \%$ other, mean number of food addiction symptoms 6.35 $\mathrm{SD}=2.9$ ).

\subsubsection{Score of perfectionism (MIPS)}

The two scores, adaptive and maladaptive perfectionism within training conditions ranked from 1 to 6 on a 6-point Likert-Scale. Mean values for both subcategories are seen in Tabelle 10.

Tabelle 10: Mean values for both categories of perfectionism in three subsamples

\begin{tabular}{|l|l|l|}
\hline & $\begin{array}{l}\text { MIPS striving for } \\
\text { perfectionism (adaptive } \\
\text { perfectionism) }\end{array}$ & $\begin{array}{l}\text { MIPS concern of } \\
\text { imperfection } \\
\text { (maladaptive } \\
\text { perfectionism) }\end{array}$ \\
\hline Total sample $(\mathrm{n}=1025)$ & $3.53(\tilde{x}=3.6 ; \mathrm{SD}=1.4)$ & $2.63(\tilde{x}=2.4 ; \mathrm{SD}=1.2)$ \\
\hline $\begin{array}{l}\text { Participants at risk for exercise } \\
\text { dependence }(\mathrm{n}=314)\end{array}$ & $3.95(\tilde{x}=4.2 ; \mathrm{SD}=1.4)$ & $3.14(\tilde{x}=3.2 ; \mathrm{SD}=1.2)$ \\
\hline $\begin{array}{l}\text { Participants with food addiction }(\mathrm{n}=64) \\
\text { Participants at risk for exercise } \\
\text { dependence and food addiction }(\mathrm{n}= \\
\text { 34) }\end{array}$ & $4.60(\tilde{x}=5.0 ; \mathrm{SD}=1.1)$ & $3.85(\tilde{x}=3.8 ; \mathrm{SD}=1.3)$ \\
\hline
\end{tabular}


5.5.4Correlations between food addiction and exercise dependence, and between food addiction and perfectionism

People with and without food addiction significantly differ for exercise dependence $\left(\mathrm{X}^{2}\right.$ $=16.250, \mathrm{df}(1), p=.000, \mathrm{Phi}=.126, p=.000$ ). People with food addiction (Median $=$

4.70) have higher strives for perfectionism than people without food addiction (median = 3.60; Mann-Whitney U-test $z=-4,664 p=.000$ ). The effect size according to Cohen (J. Cohen, 1992) is .60 and represents a strong effect. People with food addiction (Median $=3.50$ ) have higher concerns of imperfection than people without food addiction (median = 2.40; Mann-Whitney U-test $z=-6.355 p=.000$ ). The effect size according to Cohen (J. Cohen, 1992) is .94 and represents a strong effect.

\subsubsection{Predictors of food addiction}

The relationship between YFAS 2.0 Food Addiction as a criterion (binary outcome variable) with the predictor variables (exercise dependence and perfectionism) was assessed via a logistic regression model. This model shows significant values for the model in total $\left(\mathrm{X}^{2}=51.883, \mathrm{df}(3), p=.000\right)$, for the variable MIPS concern of imperfection (Wald $(1)=17.604, p=.000$ ) and a nearly significant value for exercise dependence (Wald $(1)=3.584, p=.058$ ). The value of Nagelkerke $R^{2}$ is .132 which represents a strong effect according to Cohen $(f=.39)(J$. Cohen, 1992; Jacob Cohen, 1988).

The chance of being "diagnosed“ with food addiction is elevated by $122 \%$ $(\operatorname{Exp}(B)=2.217 ; p=.000)$ for people who have higher concerns of imperfection and by $69 \%(\operatorname{Exp}(B)=1.690 ; p=.058)$ for people being at risk of exercise dependence.

\subsection{DISCUSSION AND CONCLUSION}

\subsubsection{Discussion of YFAS 2.0}

Prevalence of YFAS 2.0 food addiction was $6.3 \%$, which is comparable to community based samples throughout the world (Meule \& Gearhardt, 2014) and is similar to one study representative for the German population (Hauck et al., 2017b). The endorsement of every of the eleven YFAS food addiction symptoms significantly 
differs between athletes with and without food addiction, indicating that people with food addiction show different eating behaviors, than healthy subjects.

The mean YFAS 2.0 symptom count in people with food addiction was 6.27, which indicates a severe type of food addiction and is higher than most study results (Pursey et al., 2014), however comparable to one German study in people suffering from bulimia nervosa (Meule, von Rezori, \& Blechert, 2014). Research found that various types of addictions have been noted to occur simultaneously within individuals (National Institute on Drug Abuse, 2011; Volkow, 2010). This may give a hint that amateur athletes with addictive-like eating behavior may also suffer from bulimia nervosa and raises the question of distinction between food addiction and other eating disorders. Thus, the prevalence in total is not higher than in the general German population as assumed within the first hypothesis, but those participants who actually reported food addiction may suffer somewhat stronger.

\subsubsection{Discussion of FESA}

Prevalence of exercise dependence was $30.6 \%$, which is higher than international study results, where prevalence rates between 3 and $29 \%$ were found (Lichtenstein \& Jensen, 2016). The first hypothesis was partly confirmed. The current study demonstrates that there is a percentage of endurance amateur athletes in Germany, who may be in need of treatment. However, individual characteristics may further influence and should be assessed and considered in possible therapeutic treatment situations in the future.

In participants with exercise dependence $(n=314)$ the prevalence rate of food addiction is $10.8 \%$ and thus higher than in the whole sample. Probably individuals with exercise dependence represent a vulnerable subgroup to suffer from food addiction. Already more than 10 years ago, one Norwegian study (Sundgot-Borgen \& Torstveit, 2004) found higher prevalence rates of disordered eating in athletes than in non-athletes, which stresses the current results, as food addiction may be considered as one form of disordered eating. Both studies support the importance of future research in eating-related problems in (amateur) athletes (Joy, Kussman, \& Nattiv, 2016). 


\subsubsection{Discussion of MIPS}

The values for both subscales, MIPS striving for perfectionism and MIPS concern of imperfection, are increased in people with exercise dependence, still higher in people with food addiction and even higher in people with both, exercise dependence and food addiction. This indicates that people with an addictive-like behavior (exercise and/or eating) are in their training conditions more likely to a positive striving for perfectionism; however also to negative concerns of imperfection.

\subsubsection{Discussion of correlations between YFAS 2.0, FESA and MIPS}

Amateur athletes with food addiction, compared to those without food addiction, are at higher risk for exercise dependence, show higher striving for perfectionism in training and higher fear of imperfection in training. Probably their higher motivation to be perfect leads to an unhealthy fear of imperfection, which could lead to a vicious circle of pathological perfectionism, followed by a higher amount of exercising in order to improve the personal performance, but resulting in dependence to exercise. Additionally, perfectionism is strongly correlated to eating disorders (Herpertz, Zwaan, \& Zipfel, 2015). People who are afraid to be imperfect may tend to invest much more in being "perfect" in nearly every field of their life, control themselves very strictly and set themselves high goals. Probably they lose this perfectionism in one field of their life, for example in the eating behavior, and spoil themselves with palatable foods, e.g. as a reward for the exhausting exercise they do every day. This may switch into a detrimental effect and subsequently a development of disordered eating, like food addiction. However, people, who exercise a lot burn a high amount of calories by training and subsequently need to strictly choose their food items and eat many calories in order to balance the caloric intake and need. For some athletes, the balanced intake of calories could be problematic and a loss of control over eating (= one main symptom of food addiction) and thus problematic eating behavior and/or a food addiction - may arise. Furthermore, so called "hunger knocks" may also play a role in unbridled food intake. Especially in long-term endurance exercise sessions where glycogen depots are emptied, "hunger knocks" may arise and only a very rapid caloric intake can compensate dizziness or fatigue, which may lead to unintended uncontrolled eating. Another aspect is the use of exercise as a possibility 
to lose weight - especially in endurance sports a low body weight can improve the performance - and some athletes may end up in a vicious circle of unbalanced training and eating, resulting in pathologic behavior. On the other way round, people who have problems controlling their food intake may use exercise as a possibility to compensate the feared weight gain by doing excessive sports and may also end up in a vicious circle.

Nevertheless, only six percent of the study cohort shows a food addiction. One explanation could be that most amateur athletes try to follow a healthy lifestyle and try to avoid foods high in sugar, high in fat and high in salt, which were seen as the main agent for developing an YFAS food addiction. Probably food addiction is a construct that can more likely be found in people with obesity, eating disorders and/or addictive disorders, rather than in healthy athletes focusing on healthy weight and body shape. Consequently, the currently screened athletes may suffer from an additional eating disorder. This needs to be investigated in further studies. The mean number of food addiction symptoms found in this food-addicted amateur athletes is comparable to those numbers found in people suffering from an eating disorder (e.g. bulimia nervosa; Meule et al., 2014). This may give a hint to a potential anorexia athletica or an exercise bulimia and has to be assessed in future research.

\subsection{Limitations}

Anthropometric data of the participants were self-reported. In athletes, the significance of the BMI should be doubtfully debated as it may not be indicative of the true body composition. Nonetheless the BMI is considered as the most appropriate assessment method in online surveys. Probably the questionnaire YFAS 2.0 is not applicable in athletes, because it was invented in order to explain rising prevalence rates of obesity and therefore the YFAS does not ask for addictive-like tendencies or eating disorders in general, but eating disorders related to overeating and binges. The survey was conducted online with no possibility to control for the given answers; this also includes the athletic condition. Yet, future work is needed to clearly understand the relationship between 'food addiction', other forms of eating pathology and influencing factors. Additionally, it is unclear whether something like an addiction in the field of food/eating/nutrition really exists at all. The question is whether or not 
this may exist as a distinct disorder or as a characteristic of an already existing eating disorder, like bulimia nervosa or binge eating disorder.

\subsection{CONCLUSION}

Results demonstrate that a significant part of German athletes has a risk for exercise dependence and food addiction. At-risk athletes need greater clinical attention. Further research should be conducted to help coaches, teammates and clinicians to develop enhanced awareness and appropriate interventions (Youngman, 2007).

\subsection{References}

- American Psychiatric Association (Ed.). (1998). Diagnostic and statistical manual of mental disorders: DSM-IV; includes ICD-9-CM codes effective 1. Oct. 96 (4. ed., 7. print). Washington, DC.

- American Psychiatric Association (Ed.). (2013). Diagnostic and statistical manual of mental disorders: DSM-5 (5. ed). Washington, DC: American Psychiatric Publ.

- Breuer, S., \& Kleinert, J. (2009). Primäre Sportsucht und bewegungsbezogene Abhängigkeit - Beschreibung, Erklärung und Diagnostik. In Rausch ohne Drogen: substanzungebundene Süchte (pp. 191-218). Wien: Springer.

- Brunault, P., Courtois, R., Gearhardt, A. N., Gaillard, P., Journiac, K., Cathelain, S., Ballon, N. (2016). Validation of the French Version of the DSM-5 Yale Food Addiction Scale (YFAS 2.0) in a Nonclinical Sample. The Canadian Journal of Psychiatry. https://doi.org/10.1177/0706743716673320

- Consultation on Obesity (Ed.). (2000). Obesity: preventing and managing the global epidemic: report of a WHO consultation ; [Consultation on Obesity, 1997 Geneva, Switzerland]. Geneva: World Health Organization.

- Corwin, R. L. W., \& Hayes, J. E. (2014). Are Sugars Addictive? Perspectives for Practitioners. In J. M. Rippe (Ed.), Fructose, High Fructose Corn Syrup, Sucrose and Health (pp. 199-215). New York, NY: Springer New York. Retrieved from http://link.springer.com/10.1007/978-1-4899-8077-9_13

- Frost, R. O., Marten, P., Lahart, C., \& Rosenblate, R. (1990). The dimensions of perfectionism. Cognitive Therapy and Research, 14(5), 449-468.

https://doi.org/10.1007/BF01172967 
- Gearhardt, A. N., Corbin, W. R., \& Brownell, K. D. (2009). Food Addiction: An Examination of the Diagnostic Criteria for Dependence. Journal of Addiction Medicine, 3(1), 1-7. https://doi.org/10.1097/ADM.0b013e318193c993

- Gearhardt, A. N., Corbin, W. R., \& Brownell, K. D. (2016). Development of the Yale Food Addiction Scale Version 2.0. Psychology of Addictive Behaviors, 30(1), 113121. https://doi.org/10.1037/adb0000136

- Gearhardt, A. N., Davis, C., Kuschner, R., \& Brownell, K. D. (2011). The addiction potential of hyperpalatable foods. Current Drug Abuse Reviews, 4(3), 140-145.

- Haase, A. M., Prapavessis, H., \& Owens, R. G. (1999). Perfectionism and Eating Attitudes In Competitive Rowers: Moderating Effects of Body Mass, Weight Classification and Gender. Psychology \& Health, 14(4), 643-657. https://doi.org/10.1080/08870449908410755

- Hall, H. K., Hill, A. P., Appleton, P. R., \& Kozub, S. A. (2009). The mediating influence of unconditional self-acceptance and labile self-esteem on the relationship between multidimensional perfectionism and exercise dependence. Psychology of Sport and Exercise, 10(1), 35-44. https://doi.org/10.1016/j.psychsport.2008.05.003

- Hauck, C., Weiß, A., \& Ellrott, T. (2016). Relationship between "food addiction“, restrained eating behavior, mental health status and score of binge eating in a morbidly obese German sample. Adipositas, 10(4), 215-220.

- Hauck, C., Weiß, A., Schulte, E. M., Meule, A., \& Ellrott, T. (2017). Prevalence of "Food Addiction" as Measured with the Yale Food Addiction Scale 2.0 in a Representative German Sample and Its Association with Sex, Age and Weight Categories. Obesity Facts, 12-24. https://doi.org/10.1159/000456013

- Hewitt, P. L., Flett, G. L., Turnbull-Donovan, W., \& Mikail, S. F. (1991). The Multidimensional Perfectionism Scale: Reliability, validity, and psychometric properties in psychiatric samples. Psychological Assessment, 3(3), 464-468. https://doi.org/10.1037/1040-3590.3.3.464

- Hill, A. P., Robson, S. J., \& Stamp, G. M. (2015). The predictive ability of perfectionistic traits and self-presentational styles in relation to exercise dependence. Personality and Individual Differences, 86, 176-183. https://doi.org/10.1016/j.paid.2015.06.015

- Innamorati, M., Imperatori, C., Manzoni, G. M., Lamis, D. A., Castelnuovo, G., Tamburello, A., Fabbricatore, M. (2015). Psychometric properties of the Italian Yale Food Addiction Scale in overweight and obese patients. Eating and Weight Disorders - Studies on Anorexia, Bulimia and Obesity, 20(1), 119-127. https://doi.org/10.1007/s40519-014-0142-3 
- Lichtenstein, M. B., \& Jensen, T. T. (2016). Exercise addiction in CrossFit: Prevalence and psychometric properties of the Exercise Addiction Inventory. Addictive Behaviors Reports, 3, 33-37. https://doi.org/10.1016/j.abrep.2016.02.002

- Meule, A., \& Gearhardt, A. N. (2014). Five years of the Yale Food Addiction Scale: Taking stock and moving forward. Current Addiction Reports, 1(3), 193-205. https://doi.org/10.1007/s40429-014-0021-z

- Meule, A., \& Kübler, A. (2012). The Translation of Substance Dependence Criteria to Food-Related Behaviors: Different Views and Interpretations. Frontiers in Psychiatry, 3. https://doi.org/10.3389/fpsyt.2012.00064

- Meule, A., Müller, A., Gearhardt, A. N., \& Blechert, J. (2016). German version of the Yale Food Addiction Scale 2.0: Prevalence and correlates of "food addiction" in students and obese individuals. Appetite. https://doi.org/10.1016/j.appet.2016.10.003

- Müller, A., Claes, L., Smits, D., Gefeller, O., Hilbert, A., Herberg, A., ... de Zwaan, M. (2013). Validation of the German Version of the Exercise Dependence Scale. European Journal of Psychological Assessment, 29(3), 213-219. https://doi.org/10.1027/1015-5759/a000144

- NIDA. (2011). Comorbidity: Addiction and Other Mental Illnesses. Retrieved August 12, 2016, from https://www.drugabuse.gov/publications/drugfacts/comorbidityaddiction-other-mental-disorders

- Ogden, J., Veale, D., \& Summers, Z. (1997). The Development and Validation of the Exercise Dependence Questionnaire. Addiction Research, 5(4), 343-355. https://doi.org/10.3109/16066359709004348

- Regner, M. F., Dalwani, M., Yamamoto, D., Perry, R. I., Sakai, J. T., Honce, J. M., \& Tanabe, J. (2015). Sex Differences in Gray Matter Changes and Brain-Behavior Relationships in Patients with Stimulant Dependence. Radiology, 277(3), 801-812. https://doi.org/10.1148/radiol.2015142541

- Rhéaume, J., Freeston, M. H., Ladouceur, R., Bouchard, C., Gallant, L., Talbot, F., \& Vallières, A. (2000). Functional and dysfunctional perfectionists: are they different on compulsive-like behaviors? Behaviour Research and Therapy, 38(2), 119-128. https://doi.org/10.1016/S0005-7967(98)00203-4

- Schipfer, M. (2015). Sportbindung und Sportsucht im Ausdauersport: Theorie Diagnostik - Empirie. Hamburg: Kovač.

- Schulte, E. M., Avena, N. M., \& Gearhardt, A. N. (2015). Which Foods May Be Addictive? The Roles of Processing, Fat Content, and Glycemic Load. PLOS ONE, 10(2), e0117959. https://doi.org/10.1371/journal.pone.0117959 
- Slaney, R. B., Rice, K. G., Mobley, M., Trippi, J., \& Ashby, J. S. (2001). The Revised Almost Perfect Scale. Measurement and Evaluation in Counseling and Development, v34(3), 130-45.

- Stangl, Werner. (2016). Sucht \& Drogen, Lernen. [werner stangl]s arbeitsblätter. Retrieved June 12, 2016, from http://arbeitsblaetter.stangl-taller.at/SUCHT/

- Stöber, J. (2004). Skalendokumentation "Perfektionismus im Sport"/ Joachim Stöber ... Martin-Luther-Universität, Institut für Pädagogik. (Institut für Pädagogik, Ed.). Halle (Saale): Martin-Luther-Universität Halle-Wittenberg, Institut für Pädagogik.

- Stoll, O., Lau, A., \& Stoeber, J. (2008). Perfectionism and performance in a new basketball training task: Does striving for perfection enhance or undermine performance? Psychology of Sport and Exercise, 9(5), 620-629. https://doi.org/10.1016/j.psychsport.2007.10.001

- Swarna Nantha, Y., Abd Patah, N. A., \& Ponnusamy Pillai, M. (2016). Preliminary validation of the Malay Yale Food Addiction Scale: Factor structure and item analysis in an obese population. Clinical Nutrition ESPEN, 16, 42-47. https://doi.org/10.1016/j.clnesp.2016.08.001

- US National Library of Medicine, \& National Instiutes of Health. (2016). PubMed.gov. Retrieved August 12, 2016, from https://www.ncbi.nlm.nih.gov/pubmed

- Volkow, N. D. (2010). Comorbidity: Addiction and Other Mental Disorders. Retrieved August 12, 2016, from https://d14rmgtrwzf5a.cloudfront.net/sites/default/files/rrcomorbidity.pdf

- Zeeck, A., Leonhart, R., Mosebach, N., Schlegel, S., Linster, H. W., \& Hartmann, A. (2013). Psychopathologische Aspekte von Sport: Eine deutsche Adaptation der „Exercise Dependence Scale“ (EDS-R). Zeitschrift für Sportpsychologie, 20(3), 94106. https://doi.org/10.1026/1612-5010/a000099

- Zeeck, A., \& Schlegel, S. (2012). Sportliche Aktivität und Essstörungen. In R. Fuchs \& W. Schlicht, Seelische Gesundheit und sportliche Aktivität (pp. 229-250). S.I.: Hogrefe Verlag.

- Ziauddeen, Farooqi, \& Fletcher. (2012a). Food addiction: is there a baby in the bathwater? Nature Reviews Neuroscience, 13(7), 514-514. https://doi.org/10.1038/nrn3212-c2

- Ziauddeen, Farooqi, \& Fletcher. (2012b). Obesity and the brain: how convincing is the addiction model? Nature Reviews Neuroscience. https://doi.org/10.1038/nrn3212

- Ziauddeen, \& Fletcher. (2013). Is food addiction a valid and useful concept?: Food addiction: valid and useful? Obesity Reviews, 14(1), 19-28. https://doi.org/10.1111/j.1467-789X.2012.01046.x 
- Ziemainz, H., Stoll, O., Drescher, A., Erath, R., Schipfer, M., \& Zeulner, B. (2013). Die Gefährdung zur Sportsucht in Ausdauersportarten. Deutsche Zeitschrift Für Sportmedizin, 2013(02), 57-64. https://doi.org/10.5960/dzsm.2012.057 


\subsection{POSTER 'Food Addiction' nicht nur bei Adipositas?!}

- Zum Zusammenhang zwischen der potentiellen neuen Essstörung 'Food Addiction', etablierten Essstörungen und Sportsucht (Hauck et al.2017, Artikel dazu ist in Arbeit)

Hintergrund: Bei Personen mit Essstörungen (ED) kann häufig ein exzessives Bewegungsverhalten bis hin zu einem sportsüchtigen Verhalten beobachtet werden. Ein erhöhtes Risiko an einer ED zu erkranken ist unter anderem bei Athleten (z.B. in Ausdauer- oder ästhetischen Sportarten) zu finden. Das Konstrukt der „Food Addiction" (FA) stellt möglicherweise eine neue weitere Form der ED dar.

Ziele: Es soll untersucht werden, ob sich der bestehende Zusammenhang zwischen ED und exzessivem Sporttreiben (EXD) auch zwischen FA und EXD wiederfindet.

Methoden: Mittels eines Onlinefragebogens bestehend aus Yale Food Addiction Scale 2.0, Eating Disorder Diagnostic Scale und Fragebogen zur Erfassung des Sportverhaltens von Ausdauersportlern wurden 1204 deutschsprachige, erwachsene Männer und Frauen nach Selbstauskunft befragt, darunter 1025 Amateurathleten ( 4 Stunden Sport/Woche, 44 \% Männer, Ø 36 Jahre, Ø BMl 23 kg/m², 78 \% Ausdauersportler, $82 \%$ Wettkampfteilnehmer).

Ergebnisse: Unter den Amateurathleten betrugen die Prävalenzen von ED 6,7\%, von EXD 30,6 \% und von FA 6,2 \%. Es besteht ein Zusammenhang zwischen ED und FA bei sportsuchtgefährdeten Athleten $\left({ }^{2}=70,034\right.$, df(1), $p<0,001$; Cramers Phi $=0,472, p<0,001)$. Schlussfolgerung: Weitere Studien sind notwendig, um beeinflussende Parameter auf die Zusammenhänge von ED, FA, EXD zu untersuchen und mögliche Interventions- und Präventionsansätze für Athleten, Trainer und medizinisches Personal zu entwickeln.

\section{Referenzen:}

- Meule, A., Müller, A., Gearhardt, A. N., \& Blechert, J. (2016). German version of the Yale Food Addiction Scale 2.0: Prevalence and correlates of "food addiction" in students and obese individuals. Appetite. https://doi.org/10.1016/j.appet.2016.10.003

- Schipfer, M. (2015). Sportbindung und Sportsucht im Ausdauersport: Theorie Diagnostik - Empirie. Hamburg: Kovač. 
- Stice, E., Telch, C. F., \& Rizvi, S. L. (2000). Development and validation of the Eating Disorder Diagnostic Scale: A brief self-report measure of anorexia, bulimia, and binge-eating disorder. Psychological Assessment, 12(2), 123131. https://doi.org/10.1037/1040-3590.12.2.123 
6. ,Food Addiction': - Suchtartiges Essverhalten - Stand der Forschung mit der Yale Food Addiction Scale

Der bereits publizierte Originalartikel ist mit Genehmigung des Verlags im Anhang zu finden. 
7. Zusammenhänge zwischen Genuss und Übergewicht/ Adipositas English: Relationships between pleasure and overweight/obesity

Der bereits publizierte Originalartikel ist mit Genehmigung des Verlags im Anhang zu finden. 


\section{Teil 3 Diskussion und Schlussfolgerung}

\section{Diskussion}

Im vorliegenden Kapitel „Diskussion“ werden die Daten der aufgeführten Studien erörtert (siehe Teil 2 - „Eigene Publikationen zu Food Addiction“). Nicht alle Ergebnisse wurden bereits veröffentlicht, werden aber im Rahmen der Dissertationsschrift mit diskutiert.

Im ersten Kapitel des zweiten Dissertationsteiles (Kapitel 3) wird die deutsche Bevölkerungserhebung (Hauck, Weiß, Schulte, Meule, \& Ellrott, 2017) beschrieben. In der nun folgenden Diskussion wird diese Stichprobe als Repräsentativstichprobe bezeichnet, denn in dieser Studie wurde die YFAS 2.0 erstmals weltweit in einer repräsentativen Stichprobe eingesetzt. Die vorliegenden Daten stellen somit die ersten Erkenntnisse überhaupt $\mathrm{zu}$ suchtartigem Essverhalten in einer Bevölkerungsstichprobe dar. Für die deutsche Bevölkerung lagen zudem nur wenige Studien zu Food Addiction, gemessen mit der YFAS 2.0, vor. Deshalb wurde des Weiteren eine klinische Stichprobe an Personen mit morbider Adipositas durchgeführt. Die Ergebnisse dieser Erhebung sind in Kapitel 4 aufgeführt. Diese Stichprobe wird im Folgenden als Klinikstichprobe bezeichnet. Eine weitere eigene Studie entstand im Rahmen eines Samples aus leistungsorientierten Ausdauersportlern. Diese Ergebnisse sind in Kapitel 5 aufgeführt (Hauck, Schipfer, Ellrott, \& Cook, n.d.; Hauck, Weiß, \& Ellrott, 2016; Hauck et al., 2017). Kapitel 6 beinhaltet einen Übersichtsartikel zum aktuellen Stand der Forschung mit der YFAS (Hauck \& Ellrott, 2017a) und Kapitel 7 eine Studie, die einen weiteren bedeutsamen Aspekt des Essverhaltens untersucht - den Genuss (Hauck \& Ellrott, 2017b). Denn der Genuss beim Essen könnte für Erfolge in Prävention und Therapie von pathologischem Essverhalten, wie Übergewicht/Adipositas, von hoher Relevanz sein.

In der Diskussion werden zunächst die Grundannahmen von Food Addiction aufgegriffen. Anschließend werden die Prävalenzen von Food Addiction nach unterschiedlichen demographischen Variablen, die Symptomausprägungen der YFAS 2.0 und weitere potentielle Einflussfaktoren auf Food Addiction erörtert. Daraufhin werden potentielle Überschneidungen und Abgrenzungen von Food Addiction und etablierten Essstörungen, sowie Sportsucht diskutiert und limitierende kritische Punkte am Konstrukt der Food Addiction und dem Auswertungsinstrument 
YFAS aufgezeigt. Das abschließende Kapitel 9 beinhaltet eine allgemeine Schlussfolgerung und gibt einen Ausblick auf neue Forschungsfragen und zukünftiges Forschungspotential.

\subsection{Food Addiction und Makronährstoffe}

Im Rahmen eines Forschungsprojektes wurde von Monteiro und Kollegen ein Klassifizierungssystem für Lebensmittel nach deren Prozessierungsstufen erstellt (Monteiro, Levy, Claro, Castro, \& Cannon, 2010). Diese Forschung konnte aufzeigen, dass Lebensmittel in der höchsten Prozessierungsstufe dahingehend formuliert werden, dass sie höchst schmackhaft, attraktiv in der Verpackung, lange haltbar und ubiquitär konsumierbar sind. Die ultraprozessierten Lebensmittel stehen des Weiteren in direktem Zusammenhang zu Erkrankungen wie Adipositas, metabolischem Syndrom und Dyslipidämie (Monteiro et al., 2018). Außerdem regen plakative Marketing- und Präsentationsstrategien zum Konsum der Produkte an (Monteiro et al., 2018).

Gesichert ist zudem, dass Drogen und Nahrungsmittelbestandteile im Gehirn grundsätzlich dieselben universalen neurobiologischen Signalwege ansprechen (Hajnal, Smith, \& Norgren, 2004; Volkow \& Wise, 2005). Hochprozessierte, fett- und zuckerreiche Lebensmittel scheinen daher ähnliche pharmakokinetische Merkmale zu zeigen wie Drogen, und daher mit suchtartigem Essverhalten assoziiert zu sein (Schulte, Avena, \& Gearhardt, 2015). Neuere Studien lassen vermuten, dass solche Effekte vor allem bei einer bestimmten Kombination aus Fett und Kohlenhydraten in Lebensmitteln zu beobachten sind, nicht jedoch bei Lebensmitteln, die primär aus Kohlenhydraten bestehen (Lemeshow et al., 2018). Entsprechend scheinen nicht alle hochprozessierten Lebensmittel mit Food Addiction assoziiert zu sein. Die Food Addiction-Forschung basiert somit auf der Grundannahme, dass zumindest bestimmte, hochverarbeitete Lebensmittel existieren, die durch ihre inhärenten Eigenschaften suchtartiges Potential besitzen (Brownell \& Gold, 2012b; Gearhardt, Davis, Kuschner, \& Brownell, 2011).

Die exakten stofflichen Grundlagen einer Food Addiction sind jedoch vergleichsweise unklar. Möglicherweise ist Food Addiction auch eher eine Verhaltenssucht/ein pathologisches Essverhalten als eine Substanzgebrauchsstörung (Hebebrand et al., 2014). Die vorliegende 
Dissertationsschrift ist nicht dazu ausgelegt diese Mechanismen zu prüfen. Stattdessen werden phänomenologische Aspekte von Food Addiction, sowie deren Überlappung mit unterschiedlichen Dimensionen des Essverhaltens in verschiedenen Bevölkerungsstichproben untersucht.

\subsection{Prävalenzen von Food Addiction}

In vorliegender Dissertationsarbeit sollen zunächst die Prävalenzen von Food Addiction in den einzelnen Stichproben diskutiert werden. Die eigenen Forschungsergebnisse zeigen Food Addiction-Raten von 7,9\% in der Repräsentativstichprobe (Hauck et al., 2017), 29,7 \% in der klinischen Stichprobe mit morbider Adipositas (Hauck et al., 2016) und 6,2 \% in der Sportlerstichprobe (Hauck et al., n.d.). Diese Ergebnisse stellen die jeweils ersten Erkenntnisse, gemessen mit der YFAS 2.0, für die deutsche Bevölkerung dar.

Große Populationsstudien ermittelten Food Addiction-Raten von 5 bis $10 \%$ ( Meule \& Gearhardt, 2014b; Pursey, Stanwell, Gearhardt, Collins, \& Burrows, 2014; Schulte \& Gearhardt, 2017). Der in Deutschland gefundene Wert von 7,9 \% liegt genau in diesem Bereich, was darauf schließen lässt, dass die Food Addiction-Raten in den USA und in anderen europäischen Ländern mit denen aus Deutschland vergleichbar sind. Mögliche Ursachen könnten vergleichbare Lebens- um Umweltbedingungen in den benannten Staaten sein. Zur Einschätzung des Wertes von $7,9 \%$ in einer deutschen Repräsentativstichprobe wurde dieser auf die Bevölkerungszahl umgerechnet. Es zeigt sich, dass bei einer Rate von 7,9 \% rund 4 Millionen Deutsche die Kriterien für eine Food Addiction erfüllen. $\mathrm{Zu}$ Vergleichszwecken dieser Zahlen sollen die Prävalenzen für psychische und Verhaltensstörungen durch Alkohol und Drogen aufgeführt werden: diese betrugen im Jahr 2010 für die deutsche Bevölkerung über 15 Jahren 5,4 \% (World Health Organization, 2014), respektive 10-15 \% (Ahmed, Avena, Berridge, Gearhardt, \& Guillem, 2013). Alkoholismus oder Kokainabhängigkeit sind Erkrankungen die weitreichende Beachtung finden und wofür zahlreiche Präventions- und Therapieansätze vorliegen (Anonyme Alkoholiker Interessengemeinschaft e. V., 2018; Gorelick, 2015; Stock, 2017). Da die Prävalenz von Food Addiction ähnliche Werte aufweist wie die von Alkohol- oder Kokaingebrauchsstörung, spricht dies für 
die hohe Relevanz von Food Addiction und den großen Forschungsbedarf, vor allem im Hinblick auf die klinische und sozioökonomische Relevanz.

Die eigenen Ergebnisse für die Sportlerstichprobe zeigen eine Prävalenz von 6,2 \% für Food Addiction (Hauck et al., n.d.). Auch dieser Wert liegt im Bereich von 5$10 \%$ der in den großen Gesellschaftsstichprobe in den USA und Europa ermittelt wurde (Meule \& Gearhardt, 2014b; Pursey, Stanwell, Gearhardt, Collins, \& Burrows, 2014; Schulte \& Gearhardt, 2017). Um Unterschiede zur Repräsentativstichprobe zu ermitteln müssen noch Effektstärkemaße berechnet werden. Es wird vermutet, dass sportaffine Personen seltener hochverarbeitete Produkte konsumieren, die für eine Food Addiction verantwortlich gemacht werden. Eine mögliche Erklärung dafür warum die Häufigkeit von Food Addiction in der Sportlerstichprobe trotzdem mit der aus der Bevölkerungsstichprobe vergleichbar ist, kann dadurch gegeben werden, dass Sportler ein höheres Risiko aufweisen an pathologischem Essverhalten zu erkranken als der Bevölkerungsdurchschnitt. Denn leistungsorientierte Ausdauersportler stellen eine der Risikogruppen für Essstörungen dar. In der vorliegenden Studienarbeit gaben so auch mindestens 6,2 \% der Athleten an, klinisch signifikant unter ihrem Essverhalten zu leiden. In den folgenden Kapiteln soll näher diskutiert werden worunter die Athleten genau leiden könnten.

Die eigenen Ergebnisse zeigen, dass die Prävalenz von Food Addiction in der klinischen Stichprobe, die Personen mit morbider Adipositas einschloss, bei 29,7\% liegt (Hauck et al., 2016). Damit weist diese Population den höchsten Wert der drei Stichproben auf. Um dieses Ergebnis einordnen zu können, wurden vorhergehende Studien aus anderen europäischen oder amerikanischen Ländern herangezogen. Auch diese fanden höhere Prävalenzen bei Personen mit Adipositas im Vergleich zu Normalgewichtigen (Burrows, Kay-Lambkin, Pursey, Skinner, \& Dayas, 2018; Davis et al., 2011; Meule \& Gearhardt, 2014b). Zudem liegen Assoziationen zwischen Adipositas und Essstörungen, wie Binge-Eating Disorder (BED), bereits vor (Darby et al., 2009). Es scheint demnach, dass Personen mit Adipositas oder morbider Adipositas stärker von pathologischem Essverhalten, und damit auch Food Addiction, betroffen sind.

Zum jetzigen Zeitpunkt liegen primär Daten zu Food Addiction aus den USA, Kanada, Italien, Deutschland und Dänemark vor und zeigen vergleichbare Häufigkeitsverteilungen (Burrows et al., 2018; Davis \& Loxton, 2013; Flint et al., 
2014; Imperatori et al., 2014; Kromann \& Nielsen, 2012; Meule \& Gearhardt, 2014b). All diese Staaten sind vergleichbar in ihren ökonomischen und gesellschaftlichen Ausrichtungen. Zu Zahlen von anderen Kontinenten liegen nur bedingt Studien vor. Forscher um Nantha vermuten aber, dass die Prävalenzen von Food Addiction auch in anderen Staaten steigen werden, aufgrund der globalen Entwicklung mit fortschreitender Anpassung vieler Staaten an europäische oder nordamerikanische Standards (Swarna Nantha, Abd Patah, \& Ponnusamy Pillai, 2016).

\subsection{Food Addiction und BMI-Kategorie}

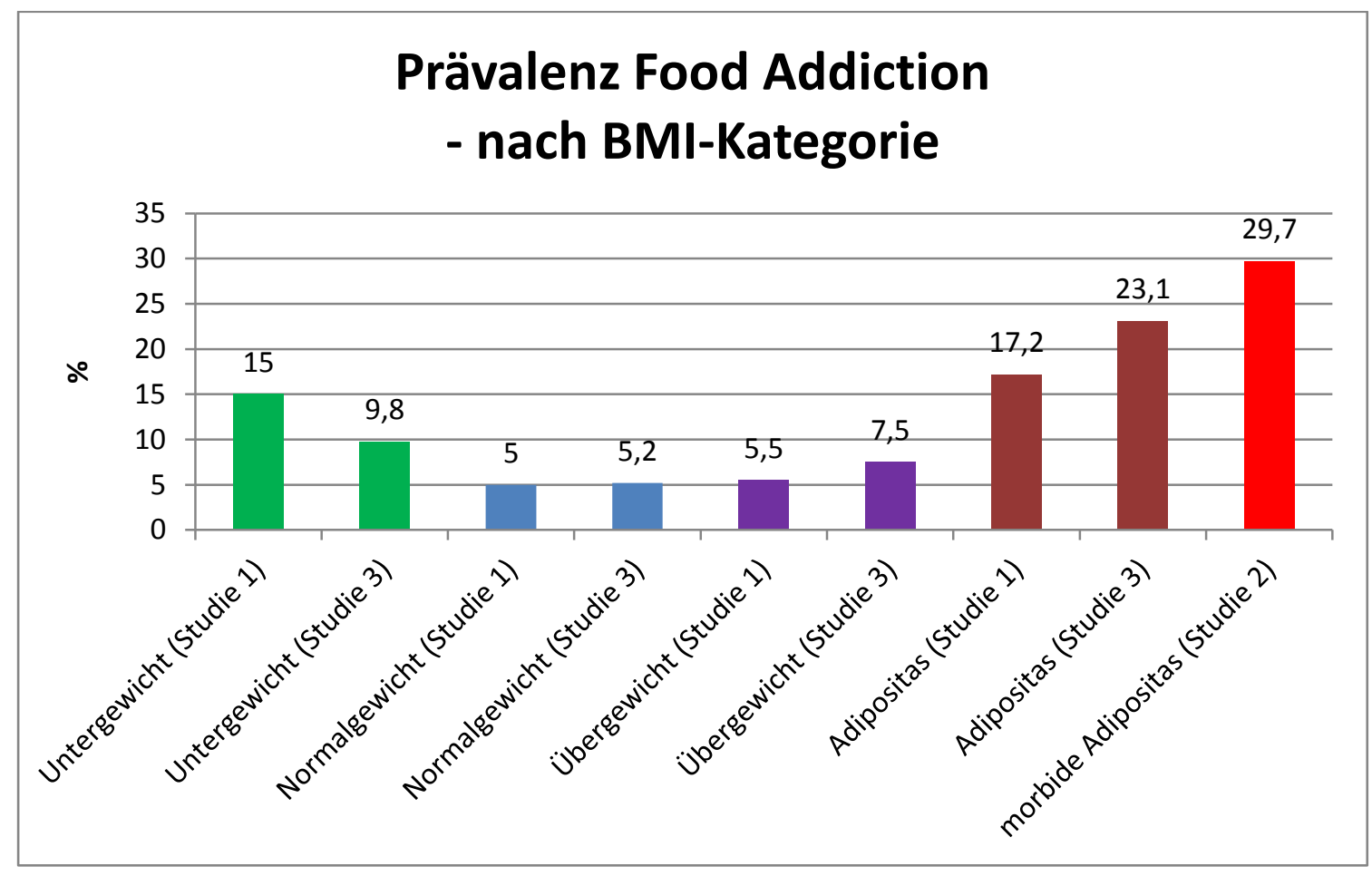

Abbildung 11: Prävalenz Food Addiction nach BMI-Kategorie in drei deutschen Stichproben (Studie 1 = repräsentativ, Studie $2=$ Klinik, Studie $3=$ Sportler, alle Daten sind im Rahmen der Dissertationszeit entstanden, wurden aber nicht alle veröffentlicht.)

Um nicht nur die Gesamtprävalenz von Food Addiction betrachten zu können, sondern auch die Häufigkeitsverteilung der einzelnen BMI-Kategorien der WHO (World Health Organization, 2000), wurden auch diese berechnet. Bei Aufteilung von Food Addiction in die Kategorien Untergewicht $\left(\mathrm{BMI}<18,5 \mathrm{~kg} / \mathrm{m}^{2}\right)$, Normalgewicht (BMI 18,5-24,9 kg/m²), Übergewicht (BMl $25-29,9 \mathrm{~kg} / \mathrm{m}^{2}$ ), Adipositas (BMI > 30 $\left.\mathrm{kg} / \mathrm{m}^{2}\right)$ und morbide Adipositas $\left(\mathrm{BMl}>35 \mathrm{~kg} / \mathrm{m}^{2}\right)$ zeigt sich eine $\mathrm{J}$-Verteilung (siehe 
Abbildung 11). So sind die Prävalenzen sowohl in den Bereichen Untergewicht, als auch Adipositas höher als bei Normal- und Übergewicht, wobei sich die höchsten bei morbider Adipositas finden.

In der Gruppe der Personen mit Adipositas oder morbider Adipositas wurden die Kriterien für Food Addiction am häufigsten erfült, und zwar zu 17,2 \%, 23,1\% respektive $29,7 \%$. Auch in vorhergehenden Studien wurden höhere Werte bei Personen mit Adipositas im Vergleich zu Normalgewicht gefunden (Burrows et al., 2018; Davis et al., 2011; Meule, Müller, Gearhardt, \& Blechert, 2016; Pursey, Collins, Stanwell, \& Burrows, 2015; VanderBroek-Stice, Stojek, Beach, vanDellen, \& MacKillop, 2017). Auf Basis dessen wird ein Zusammenhang zwischen Food Addiction und hohem BMl vermutet. Diese Vermutung konnte in Form von signifikanten Zusammenhängen für BMI und Food Addiction bestätigt werden (Repräsentativstichprobe: $\mathrm{X}^{2}(3)=34.61, p<0.001$ ). Die Wahrscheinlichkeit für eine Food Addiction war für Personen mit Adipositas im Vergleich zu Personen mit Normalgewicht um das 3,5-fache erhöht (Hauck et al., 2017). Es wird vermutet, dass das Ergebnis darauf basiert, dass Adipositas aufgrund von Interaktionen zwischen genetischer Prädisposition und Umweltfaktoren basiert (Ellrott \& Pudel, 1998). So scheinen Personen mit hohem Körpergewicht genetisch besonders für pathologisches Essverhalten (Darby et al., 2009) und somit auch Food Addiction veranlagt zu sein, und zudem verstärkt von der adipogenen Lebensmittelumwelt, mit großem Angebot an den zuvor beschriebenen hochverarbeiteten energiedichten Lebensmitteln, getriggert zu werden.

In der Gruppe der Untergewichtigen erfüllten $15 \%$ beziehungsweise 9,8 \% die Kriterien für eine Food Addiction. Die Wahrscheinlichkeit für eine Food Addiction war für Untergewichtige im Vergleich zu Normalgewichtigen um das 3-fache erhöht (Hauck et al., 2017). Die Prävalenzen von Food Addiction sind somit im Bereich Untergewicht höher als im Bevölkerungsdurchschnitt. In der Literatur lässt sich nur eine Studie finden, die explizit Personen mit Untergewicht beforschte. Die Häufigkeit von Food Addiction war in dieser spanischen Studie höher als die von uns ermittelten Werte. Allerdings erfüllten die Betroffenen zudem die Kriterien von Anorexia Nervosa oder Bulimia Nervosa (Granero et al., 2014). Es wird daher vermutet, dass die YFAS 2.0 Aspekte pathologischen Essverhaltens misst, die auch bei den etablierten Essstörungen, wie Anorexia Nervosa (AN) oder Bulimia Nervosa (BN), auftreten. Es 
scheint, dass die Erfüllung einer Food Addiction sich bei Personen mit Untergewicht möglicherweise mit dem Vorliegen einer etablierten Essstörung überlappt.

Bereits bekannt ist, dass die Prävalenzen für Essstörungen sowohl bei Personen mit geringem als auch mit hohem Körpergewicht, und auch leistungsorientierten Sportlern, erhöht sind (Deutsche Gesellschaft für Psychosomatische Medizin und Psychotherapie (DGPM), 2010). Neben dem Zusammenhang zwischen Food Addiction und hohem BMI, wird somit auch ein Zusammenhang zwischen Food Addiction und niedrigem BMI vermutet. Möglicherweise könnte Food Addiction somit eine neue Essstörung oder einen Teilaspekt einer etablierten Essstörung darstellen (Burrows et al., 2018; Gearhardt, Boswell, \& White, 2014; Gearhardt, White, \& Potenza, 2011), denn auch in vorliegenden Studien (Repräsentativ- und Sportlerstichprobe) konnten erhöhte Werte in den Bereichen Untergewicht und Adipositas festgestellt werden, was charakteristisch für Essstörungen scheint.

In der Gruppe der Normal- und Übergewichtigen erfüllen 5,0\% und 5,2\%, beziehungsweise $5,5 \%$ und $7,5 \%$ die Kriterien für eine Food Addiction. Die Häufigkeiten der Erfüllung einer Food Addiction sind in diesen BMI-Bereichen geringer als im Bevölkerungsdurchschnitt. Es wird vermutet, dass sich die Ergebnisse dadurch erklären lassen, dass Personen mit Normalgewicht und Übergewicht eine geringere Krankheitsrate aufweisen und somit auch seltener pathologisches Essverhalten zeigen (Berrington de Gonzalez et al., 2010), was durch die YFAS 2.0 gemessen werden würde.

Dennoch sind auch Prävalenzraten von rund $5 \%$ nicht zu vernachlässigen, denn eine Food Addiction wird nur identifiziert, wenn klinisch signifikantes Leiden von den Betroffenen berichtet wird. So wird auch bei Personen mit Normalgewicht pathologisches Essverhalten verzeichnet. Beispielsweise beträgt der Anteil der Normalgewichtigen an den Erkrankten einer BN mit $64 \%$, fast zwei Drittel der Erkrankten (Werte aus den USA (The Alliance for Eating Disorders Awareness, n.d.)). Aus diesem Grund sollten Personen aller BMI-Kategorien in der Food Addiction-Forschung berücksichtigt werden, da in allen BMI-Bereichen pathologisches Essverhalten auftreten kann, und somit möglicherweise auch Food Addiction.

Um zu prüfen, ob ein Zusammenhang zwischen der abhängigen Variable YFAS Symptom und der unabhängigen Variable BMI besteht, wurden des weiteren 
lineare Regressionsanalysen für die drei Stichproben durchgeführt. In der Repräsentativ- und der Sportlerstichprobe wies der BMI einen statistisch signifikanten Einfluss auf die Anzahl der YFAS-Symptom auf: repräsentative Stichprobe $(F(1,1032)=19,488, p=, 000)$, Sportlerstichprobe $(F(1,1005)=13,960$, $p=, 000)$. Pro BMI-Punkt steigt die Anzahl an FA-Symptomen in der repräsentativen Stichprobe um 0,07 Symptome und in der Sportlerstichprobe um 0,08 Symptome. In den einzelnen Stichproben können 1,8 \% und 1,3\% der Streuung der YFASSymptome durch den BMl erklärt werden, was nach Cohen (1992) einem schwachen Effekt entspricht $(f=0,14, f=0,11)$. Dies bedeutet, dass die Wahrscheinlichkeit für eine Food Addiction mit steigendem BMI ansteigt, jedoch ist die aufgeklärte Varianz durch den BMI gering, so dass zudem weitere beeinflussende Variablen für Food Addiction herangezogen werden sollten.

\subsection{Food Addiction und Geschlecht}

Eine weitere anthropometrische Variable nach der die Prävalenzen von Food Addiction unterschieden werden können, stellt das Geschlecht dar. Die eigenen Ergebnisse zeigen, dass Frauen (9,6; 9,2 \%) in der Repräsentativ- und der Sportlerstichprobe eine höhere Prävalenz für Food Addiction aufweisen als Männer (6,3; 2,5 \%; Tabelle 12). Innerhalb der Stichproben waren die Unterschiede zwischen den Geschlechtern in der Repräsentativstichprobe nur knapp nicht, dagegen in Sportlerstichprobe statistisch signifikant (Tabelle 12). Für die Klinikstichprobe konnte keine statistische Signifikanz ermittelt werden.

Tabelle 12: Prävalenz von Food Addiction in drei Stichproben nach Geschlecht

\begin{tabular}{|l|l|l|l|}
\hline Geschlecht & Repräsentativstichprobe & Klinikstichprobe & Sportlerstichprobe \\
\hline Frauen & 9,6 & 25,6 & 9,2 \\
\hline Männer & 6,3 & 36,0 & 2,5 \\
\hline Chi-Quadrat-Test & $X^{2}(1)=3,74$, & $X^{2}(1)=0,78$, & $X^{2}(1)=19,2$, \\
& $p=0,053$ & $p=0,376$ & $p<0,001$ \\
\hline
\end{tabular}

Die Ergebnisse aus der Repräsentativ- und der Sportlerstichprobe lassen vermuten, dass Frauen eine höhere Wahrscheinlichkeit haben an Food Addiction zu erkranken als Männer und somit häufiger pathologisches Essverhalten zu zeigen. Ein Vergleich soll hier zu den etablierten Essstörungen, wie $A N$ und $B N$, gezogen werden. So 
leiden Frauen in Deutschland mit 1,4 \% auch häufiger an den etablierten Essstörungen als Männer, von welchen 0,5 \% an Essstörungen erkrankt sind (Jacobi et al., 2014). Auch in den USA beträgt das Verhältnis der Essstörungen AN und BN von erwachsenen Frauen zu Männern rund 10:1 (American Psychiatric Association, 2013). Wenn Food Addiction pathologisches Essverhalten abbildet und Frauen häufiger Essstörungen und damit pathologisches Essverhalten zeigen, dann können die geschlechtsspezifischen Unterschiede in vorliegender Dissertationsschrift möglicherweise vergleichbar zu den Essstörungspathologien sein, und hierdurch erklärt werden. Dennoch sollen auch Männer in der Betrachtung von Essstörungen Berücksichtigung finden, denn auch von diesen ist ein signifikanter Anteil erkrankt (Schweizerische Arbeitsgemeinschaft für Sportpsychologie, 2002).

In der Klinikstichprobe wurde kein signifikanter Unterschied zwischen den Geschlechtern gefunden (Tabelle 12). Hierbei handelt es sich ausschließlich um Personen mit morbider Adipositas. Dass es keine Geschlechtsunterschiede bei Männern und Frauen mit hohem Körpergewicht gibt, kann möglicherweise durch den auch bei BED existierenden weniger großen Unterschied zwischen Frauen zu Männern erklärt werden (Verhältnis 2:1; American Psychiatric Association, 2013). BED wurde als Vergleichswert herangezogen, da auch BED pathologisches Essverhalten abbildet, mit hohem Körpergewicht assoziiert ist und die Geschlechtsunterschiede bei BED geringer sind als bei BN (de Zwaan, 2001). Möglicherweise sind die Geschlechtsunterschiede von Food Addiction bei Personen mit Adipositas geringer. Die nicht vorhandene Signifikanz könnte aber auch an der kleinen Stichprobe $(n=64)$ und dem kleinen Anteil an Männern $(n=25)$ liegen.

Um zu prüfen, ob ein Zusammenhang zwischen der abhängigen Variable YFAS Symptom und der unabhängigen Variable Geschlecht besteht, wurden des weiteren lineare Regressionsanalysen für die drei Stichproben durchgeführt. Nur in der Sportlerstichprobe hatte das Geschlecht einen statistisch signifikanten Einfluss auf die Anzahl der YFAS-Symptome $(F(1,1023)=16,245, p=, 000)$. Für Frauen ist die Anzahl an FA-Symptomen um 0,5 Symptome höher als bei Männern. Ein Anteil an 1,5\% der Streuung der YFAS-Symptome wird durch das Geschlecht erklärt, was nach Cohen (1992) einem schwachen Effekt entspricht $(f=0,12)$.

Dies bedeutet, dass die Wahrscheinlichkeit für eine Food Addiction für das weibliche Geschlecht im Vergleich zum männlichen erhöht ist. Jedoch ist die 
aufgeklärte Varianz durch die Alterseffekte gering, so dass weitere beeinflussende Variablen für Food Addiction herangezogen werden sollten.

\subsection{Food Addiction und Alter}

Gerade bei Essstörungen werden häufig Altersunterschiede festgestellt. So soll auch in vorliegender Arbeit die Häufigkeit von Food Addiction nach verschiedenen Altersgruppen unterschieden werden. Die eigenen Ergebnisse zeigen, dass die jeweils höchste Prävalenz für eine Food Addiction in allen drei Stichproben in der jüngsten untersuchten Altersgruppe von 18 bis 29 Jahren (12,9; 44,4; 9,4\%) auftritt (Tabelle 13). Statistisch signifikant korrelierte das Alter mit den YFAS 2.0 Symptomen für die Repräsentativstichprobe $(r=-0,22, p<0,001)$ und die Sportlerstichprobe $(r=-0,10, p=0,001)$. Für die klinische Stichprobe wurden keine signifikanten Korrelationen für Alter gefunden $(r=-0,21, p=0,09)$. Das Alter war somit negativ mit der Anzahl an Food Addiction-Symptomen korreliert.

Tabelle 13: Prävalenz von Food Addiction in drei Stichproben nach Altersgruppen

\begin{tabular}{|l|l|l|l|}
\hline Altersgruppe & Repräsentativstichprobe & Klinikstichprobe & Sportlerstichprobe \\
\hline $18-29$ & 12,9 & 44,4 & 9,4 \\
\hline $30-39$ & 9,4 & 28,6 & 5,1 \\
\hline $40-49$ & 5,3 & 38,5 & 6,5 \\
\hline $50-65$ & 5,8 & 14,3 & 0,7 \\
\hline
\end{tabular}

Die Ergebnisse lassen vermuten, dass jüngere Personen häufiger an Food Addiction leiden. Wenn Essstörungen, wie $\mathrm{AN}$ und BN, zu Vergleichszwecken herangezogen werden, dann zeigt sich auch bei diesen eine höhere Wahrscheinlichkeit für eine Essstörung im Jugendalter und jungen Erwachsenenalter. Der Anteil an Personen mit Essstörung besteht so auch zu 90 \% aus jungen Frauen zwischen 12 und 25 Jahren (Schweizerische Arbeitsgemeinschaft für Sportpsychologie, 2002; Substance Abuse and Mental Health Services Administration, 2013). Somit könnte auch Food Addiction eine Form pathologischen Essverhaltens darstellen, das verstärkt im jungen Erwachsenenalter auftritt.

Einen weiteren Erklärungsansatz für die hohe Prävalenz von suchtartigem Essverhalten in der jungen Population könnte auch der Lebensstil der jungen 
Personen darstellen. Jüngere Menschen könnten für Verlockungen der adipogenen Umwelt stärker empfänglich sein. Die Personengruppe befindet sich häufig in einem Ausbildungsverhältnis (Mischke \& Wingerter, 2012), spürt den gesellschaftlichen Druck Leistung zu erbringen, hat mit den Problemen der Vereinbarkeit von Beruf, Sozialleben und Familie zu kämpfen (Busch-Heizmann \& Holst, 2017). Zudem wird vermutet, dass sich junge Menschen noch in der Planung ihres zukünftigen Lebens befinden und so auch die Aufrechterhaltung einer guten Work-Life-Balance als eine potentielle Schwierigkeit benennen (Busch-Heizmann \& Holst, 2017; White, Hill, McGovern, Mills, \& Smeaton, 2003). Viele berichten zudem von enormem Zeitdruck mit geringen Zeitkapazitäten an Werktagen. Es werden häufig schnelle Mahlzeiten, wie Fast Food oder to-go-Gerichte konsumiert. Die Altersgruppe von 20-29 Jahren stellte im Jahr 2017 auch den Spitzenreiter der deutschen McDonald's-Kunden dar (VuMA (Arbeitsgemeinschaft Verbrauchs- und Medienanalyse), 2017). Diese schnell verzehrbaren Lebensmittel enthalten meist eine hohe Energiedichte mit viel Zucker und/oder Fett. Genau diese Art von hochprozessierten Lebensmitteln wird im Zusammenhang mit Food Addiction diskutiert (Schulte et al., 2015).

In der Klinikstichprobe wurden keine signifikanten Alterseffekte gefunden (Tabelle 13). In diese Stichprobe wurden ausschließlich Personen mit morbider Adipositas eingeschlossen. Das Ergebnis könnte dadurch erklärt werden, dass sich Adipositas vermehrt in den älteren Altersgruppen finden lässt. Denn Adipositas entwickelt sich zumeist über mehrere Jahre, und bleibt dann aber konstant über mehrere Jahrzehnte hinweg bestehen (Mensink et al., 2013). So könnte auch Food Addiction über eine längere Lebensspanne Bestand haben, so dass keine Altersunterschiede vorhanden sind. Eine Betrachtung von Personen mit BED (pathologisches Essverhalten primär bei Personen mit Adipositas) zeigt, dass das Erkrankungsalter von BED auch höher liegt als bei BN oder AN (Spurrell, Wilfley, Tanofsky, \& Brownell, 1997) und eine BED auch über eine längere Zeit bestehen bleibt. Eine andere Erklärung könnte in der Stichprobe an sich liegen. So war diese zum einen klein, und zum anderen differierten die Altersangaben weniger stark (Großteil der Gruppe Mitte 30 bis Mitte 50 Jahre alt). Diese Stichprobe konnte es möglicherweise nicht ermöglichen statistisch signifikante Alterseffekte zu testen.

Um zu prüfen, ob ein Zusammenhang zwischen der abhängigen Variable YFAS Symptom und der unabhängigen Variable Alter besteht, wurden des weiteren lineare Regressionsanalysen für die drei Stichproben durchgeführt. In allen drei 
Stichproben hatte die Anzahl an Lebensjahren einen statistisch signifikanten Einfluss auf die Anzahl der YFAS-Symptome: repräsentative Stichprobe $(F(1,1032)=39,910$, $p=, 000)$, klinische Stichprobe $(F(1,62)=4,192, p=, 040)$, Sportlerstichprobe $(F(1$, $1022)=10,086, p=, 002)$. Pro Lebensjahr fällt die Anzahl an FA-Symptomen in der repräsentativen Stichprobe um 0,05, in der klinischen Stichprobe um 0,06 und in der Sportlerstichprobe um 0,02 Symptome. In den einzelnen Stichproben können 3,6 \%, $5,0 \%$ und $1,0 \%$ der Streuung der YFAS-Symptome durch den Alterseffekt erklärt werden, was nach Cohen (1992) einem schwachen Effekt entspricht $(f=0,19, f=$ $0,23, f=0,10)$. Dies bedeutet, dass die Wahrscheinlichkeit für eine Food Addiction mit steigendem Lebensalter abnimmt, jedoch ist die aufgeklärte Varianz durch die Alterseffekte zwar höher als durch BMI (siehe Kapitel 8.3) oder Geschlecht (siehe Kapitel 8.4), aber dennoch gering, so dass weitere beeinflussende Variablen für Food Addiction herangezogen werden sollten.

\subsection{Symptomausprägungen von Food Addiction}

Neben den anthropometrischen Variablen, die wie bereits gezeigt, nur kleine Teile der Varianz aufklären konnten, wurden deshalb zudem die Symptome des DSM-5 für Substanzgebrauchsstörungen mittels des Fragebogens YFAS 2.0 abgefragt. Die elf Symptome des DSM-5 sind in Tabelle 1 zu finden. Es stellt sich die Frage, wie häufig die einzelnen Symptome in den verschiedenen Stichproben ausgeprägt sind, welche Symptome die häufigsten und die seltensten darstellen, und ob es Unterschiede in den drei Stichproben gibt. Die folgende Tabelle 14, sowie die Abbildung 12 zeigen die Ausprägungen der Symptome nach YFAS 2.0 in den drei deutschen Stichproben.

Tabelle 14: Prävalenzen Food Addiction und Ausprägung der Symptome in drei deutschen Stichproben

YFAS-Symptom

1.
Bevölkerung

2.
Personen

3. Amateur- 


\begin{tabular}{|l|l|l|l|}
\hline & $\begin{array}{c}\text { repräsentativ } \\
(\%)^{\mathrm{a}}\end{array}$ & $\begin{array}{c}\text { mit } \\
\text { morbider } \\
\text { Adipositas } \\
(\%)^{b}\end{array}$ & $\begin{array}{c}\text { Ausdauer- } \\
\text { sportler } \\
(\%)^{\mathrm{c}}\end{array}$ \\
\hline $\begin{array}{l}\text { Einnahme größerer Mengen oder länger als } \\
\text { geplant (amount) }\end{array}$ & 19,2 & 40,6 & 19,6 \\
\hline $\begin{array}{l}\text { Erfolglose Versuche zur } \\
\text { Einschränkung/Kontrolle (attempts) }\end{array}$ & 15,6 & 42,2 & 12,4 \\
\hline Hoher Zeitaufwand (time spent) & 11,6 & 23,4 & 6,3 \\
\hline Craving & 11,0 & 20,3 & 6,6 \\
\hline Versagen bei Verpflichtungen (obligation) & 17,3 & 23,4 & 6,5 \\
\hline $\begin{array}{l}\text { Substanzgebrauch trotz sozialer/persönlicher } \\
\text { Probleme (problems) }\end{array}$ & 18,3 & 25,0 & 8,6 \\
\hline Aufgabe von Aktivitäten (activities given up) & 18,9 & 12,5 & 7,1 \\
\hline Leid (impairment/distress) & 8,5 & 35,9 & 7,6 \\
\hline $\begin{array}{l}\text { Substanzgebrauch in gefährlichen Situationen } \\
\text { (physically hazardous situations) }\end{array}$ & 18,3 & 28,1 & 2,0 \\
\hline $\begin{array}{l}\text { Substanzgebrauch trotz physischer/emotionaler } \\
\text { Konsequenzen (consequences) }\end{array}$ & 12,7 & 42,2 & 6,1 \\
\hline Toleranzentwicklung (tolerance) & 7,4 & 17,2 & 5,4 \\
\hline Entzugssymptome (withdrawal) & 18,5 & 25,0 & 12,0 \\
\hline YFAS Food Addiction Prävalenz & 7,9 & 29,7 & 6,2 \\
\hline YFAS Symptomzahl (Bereich 0-11) & 1,69 & $\begin{array}{l}3,00 \\
(\text { SD 2,9) }\end{array}$ & $\begin{array}{l}0,93 \\
(\text { SD 1,98) }\end{array}$ \\
\hline
\end{tabular}

a (Hauck, 2017), ${ }^{\text {b }}$ (Hauck, 2016), ${ }^{\text {c }}$ (Hauck, under review) 


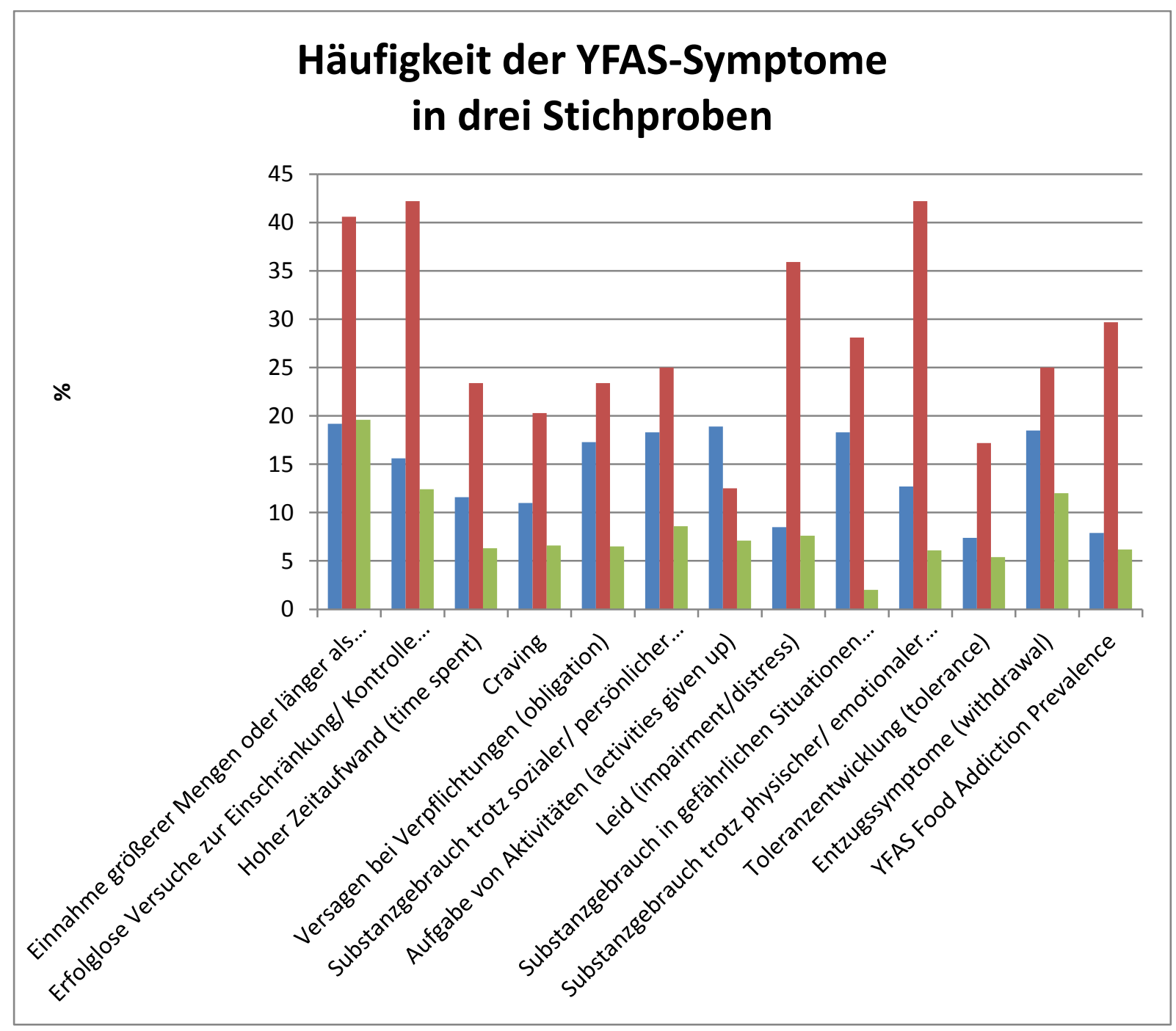

Abbildung 12: Ausprägung der Symptome in drei deutschen Stichproben (blau = repräsentativ, rot $=$ Klinik, grün $=$ Sportler)

Die Ergebnisse der Repräsentativstichprobe (blau) zeigen, dass verschiedenste Symptome in diesem Sample ausgeprägt vorliegen. So wurden sechs verschiedene Symptome mit vergleichbarer Häufigkeit angegeben (19,2 bis 17,3 \%), und die Spanne in der Erfüllung der häufigsten (19\%) zu den seltensten (7\%) Symptomen ist relativ gering (Abbildung 12). In einer Repräsentativstichprobe, wie sie hier vorliegt, werden Personen aller Gruppen befragt. Möglicherweise sind die Hintergründe dieser Personen sehr divers, so dass weitere Forschung in den einzelnen Gruppen tiefergehende Erkenntnisse bringen soll.

Im Folgenden werden die Symptome der klinischen Stichprobe (rot) näher betrachtet. Diese Ergebnisse zeigen, dass alle Symptome in der klinischen Stichprobe stärker ausgeprägt sind als in den beiden anderen Stichproben. Personen mit morbider Adipositas weisen somit nicht nur eine höhere Prävalenz an Food Addiction auf (siehe Kapitel 8.3), sie erfüllen auch alle Symptome der YFAS 2.0 - bis 
auf das Symptom „Aufgabe von Aktivitäten“ - häufiger als Personen der Repräsentativ-, sowie der Sportlerstichprobe. Offensichtlich zeigen Personen mit Adipositas verstärkt Probleme in ihrem Essverhalten.

Zudem zeigt sich in der klinischen Stichprobe ein Muster der am häufigsten genannten Symptome, was vermuten lässt, dass bestimmte Personengruppen unterschiedliche Formen von Food Addiction aufweisen. Die drei am häufigsten genannten Symptome von Personen mit morbider Adipositas sind die „Einnahme größerer Mengen oder länger als geplant“ (40,6 \%), die „erfolglosen Versuche das Essen einzuschränken/zu kontrollieren“ (42,2 \%), sowie der „Substanzgebrauch trotz physischer/emotionaler Konsequenzen“ (42,4 \%). In der Validierungsstudie zur deutschen YFAS 2.0 von Meule wurden von Personen mit Adipositas am häufigsten die Symptome „erfolglose Versuche das Essen einzuschränken/zu kontrollieren“ $(48,1 \%)$, „Substanzgebrauch trotz sozialer/persönlicher Probleme (40,6 \%) und „Substanzgebrauch trotz physischer/emotionaler Konsequenzen“ (37,6 \%) (Meule et al., 2016). Die Ergebnisse von Meule und Kollegen sind somit ähnlich den eigenen Resultaten.

Das Kriterium „Kontrollverlust“ wird durch die beiden Symptome „Einnahme größerer Mengen oder länger als geplant“ und „erfolglose Versuche das Essen einzuschränken/zu kontrollieren“ beschrieben. Dieses scheint bei pathologischem Essverhalten eines der entscheidenden Charakteristika darzustellen, denn auch weitere Forschergruppen detektierten dieses Verhalten bei Personen mit pathologischem Essverhalten (hier: BED; Colles, Dixon, \& O'Brien, 2008; Ricca et al., 2009). Es wird daher vermutet, dass besonders Personen mit Adipositas verstärkt Probleme in der Kontrolle der Nahrungsaufnahme aufweisen.

An dieser Stelle kann nun auch ein Bezug zu Suchterkrankungen gespannt werden, denn laut Benzinger stellt der Kontrollverlust eines der zentralen Elemente von Suchterkrankungen dar (Benzinger, 2013). Er geht sogar so weit, dass er postuliert: „Sucht ohne Kontrollverlust gibt es nicht.“ (Benzinger, 2013). Unter der Annahme, dass Kontrollverlust eines der zentralen Elemente von Sucht darstellt und der Kontrollverlust auch beim Essen, sowohl in der Klinik-, als auch in der Sportlerstichprobe häufig beschrieben wird, spricht dies für die Existenz einer Sucht beim Essen. 
Das Symptom Kontrollverlust wurde auch in Bezug $\mathrm{zu}$ anderen Persönlichkeitsmerkmalen erforscht. So stellt Kontrollverlust eine Facette von Impulsivität dar. Störungen der Impulskontrolle sind wiederum mit Substanzgebrauchsstörungen assoziiert (Koob \& Le Moal, 1997; Moeller, Barratt, Dougherty, Schmitz, \& Swann, 2001). Für eine Alkoholsucht wurden diese Zusammenhänge bereits erforscht (Leeman, Patock-Peckham, \& Potenza, 2012). Auch bei Übergewicht und Adipositas wurden hohe Werte an Impulsivität gefunden (Guerrieri, Nederkoorn, \& Jansen, 2008). Zusammenhänge von Kontrollverlust, Impulsivität und Food Addiction könnten in Zukunft weitere Aufklärung über die Existenz von Food Addiction als potentielle Suchterkrankung geben.

Schwierigkeiten in der Appetitkontrolle könnten auch durch die adipogene Umwelt mitbedingt werden (Ellrott \& Pudel, 1998). So könnte das omnipräsente Angebot an hochkalorischen Lebensmitteln $\mathrm{zu}$ einer hedonisch statt einer homöostatisch motivierten Nahrungsaufnahme verleiten (Finlayson, 2017) und damit zu höherer Kalorienzufuhr als tatsächlichem -bedarf, zu einer Gewichtszunahme und möglicherweise auch zu Essstörungen beitragen (Treasure, Claudino, \& Zucker, 2010). Gerade Personen mit Adipositas scheinen anfälliger für die Trigger zum Essen zu sein (Gearhardt \& Corbin, 2012). So „missbrauchen“ Personen mit hohem Körpergewicht Lebensmittel auch häufiger als Normalgewichtige, um ihre Stimmung/Laune bei Liebeskummer, Einsamkeit, Stress und Langeweile zu beeinflussen, wie unsere Studie aus Kapitel 7 zeigt (Hauck \& Ellrott, 2017b). Die dabei konsumierten Lebensmittel sind großteils hochverarbeitet und hochkalorisch mit einem hohen Anteil an Fett und Kohlenhydraten (z.B. Schokolade, Chips; Hauck \& Ellrott, 2017b). Möglicherweise stellen hochprozessierte Lebensmittel mit einer sehr hohen Energiedichte zunächst potentielle „Stimmungsaufheller" dar, verändern sich bei vulnerablen Personen jedoch hin zu potentiellen „Suchtstoffen“. Diese Annahmen könnten die hohe Erfüllungsrate des Symptoms „Substanzgebrauch trotz physischer/emotionaler Konsequenzen“ erklären. Es scheint, dass Personen mit morbider Adipositas verstärkt den Drang verspüren, Lebensmittel konsumieren zu müssen, ähnlich dem Drang nach Drogeneinnahme.

Das Symptom „Leiden“ findet sich an vierter Stelle der am häufigsten genannten Symptome (Hauck et al., 2016). Leiden bedeutet hier, dass das eigene Essverhalten sehr viel Leid verursacht, und die Betroffenen erhebliche Probleme in ihrem Leben aufgrund von Nahrung und Essen haben. Diese Probleme betrafen 
beispielsweise Altag, Arbeit, Freunde, Familie oder Gesundheit (American Psychiatric Association, 2013). Es scheint, dass gerade Personen mit hohem Körpergewicht sehr stark unter ihrem Essverhalten leiden. Zum Leidensdruck tragen auch Erfahrungen mit Stigmatisierung in Bezug zum eigenen Körpergewicht, Schamgefühle, Depressionen und Ängsten bei. Denn all diese Phänomene werden von Personen mit hohem Körpergewicht berichtet, wenn sie nach ihrem Leidensdruck gefragt werden (Kirk et al., 2014; Puhl \& Brownell, 2006; Puhl \& Heuer, 2010; Vallis, 2016).

Einen weiteren Aspekt stellt die Bedeutsamkeit von Körpergewicht und Körperbild dar. So spielen diese im Leben von Personen mit Adipositas und BED eine unverhältnismäßig große Rolle (Mitchison et al., 2018). Möglicherweise räumen sie dem Körpergewicht eine so starke Position in ihrem Leben ein, möchten dieses unbedingt verändern, scheitern jedoch, so dass sie unter dem Körpergewicht noch stärker leiden. So wird bei Personen mit hohem Körpergewicht im Vergleich zu Normalgewichtigen auch eine niedrigere Lebensqualität gemessen (Kolotkin, Meter, \& Williams, 2001). Möglicherweise könnte der hohe Leidensdruck zu geringerer Zufriedenheit mit sich selbst beitragen und somit auch zu einer geringeren selbst empfundenen Lebensqualität.

Wie bereits oben erwähnt, wurde in unserer klinischen Stichprobe das Symptom „Aufgabe von Aktivitäten“ am seltensten erfüllt (12,5\%) und damit sogar seltener als in der Repräsentativstichprobe. Dies kann als erfreuliches Ergebnis gewertet werden. Denn trotz eines erhöhten Leidensdrucks und einer vorliegenden morbiden Adipositas scheint der Konsum von Nahrungsmitteln nicht für die Aufgabe wichtiger Aktivitäten, wie Arbeiten, Zeit mit Familie oder Freunden zu verbringen, verantwortlich gemacht zu werden. Eine andere Erklärungsmöglichkeit könnte darstellen, dass Personen mit hohem Körpergewicht bestimmte Aktivitäten, wie zum Beispiel Sport, schon zuvor seltener ausführen, oder diese als weniger wichtig im Leben erachten. Deshalb wird auch kein Verlust der Aktivität empfunden. Einem Beruf nachzugehen und Zeit mit der Familie und Freunden zu verbringen ist wohl mit (fast) jedem Körpergewicht möglich. Personen mit hohem Körpergewicht haben häufig auch Familienmitglieder und einen Freundeskreis mit ähnlich hohem Körpergewicht (Christakis \& Fowler, 2007; Reich, 2003), so dass auch deren Aktivitätsspektren möglicherweise vergleichbar sind und daher keine Einschränkungen empfunden werden. 
Nun werden die Ergebnisse der Sportlerstichprobe (grün) diskutiert. Es zeigt sich, dass die Symptome von den Athleten alle seltener erfüllt werden als in den anderen beiden Stichproben; bis auf eine Ausnahme. Somit weisen Athleten seltener eine Food Addiction auf. Ähnlich wie bei den Personen mit morbider Adipositas, kann aber auch bei Athleten ein Muster der Symptomausprägungen festgestellt werden. So sind hier drei Symptome am häufigsten erfüllt. Diese sind die „Einnahme größerer Mengen oder länger als geplant" (19,7\%), die "erfolglosen Versuche das Essen einzuschränken/zu kontrollieren" (12,5\%) und die Entzugssymptome (12,0\%). Dies bedeutet, dass auch bei den Athleten der Kontrollverlust, der durch die beiden erstgenannten Symptome beschrieben wird, eine Bedeutung haben könnte.

In der Sportlerstudie wurden Entzugssymptome an dritter Stelle der häufigsten Symptome genannt. So fühlten sich $12 \%$ der Sportler gereizt, nervös oder traurig wenn sie den Konsum bestimmter Nahrungsmittel einschränkten oder deren Konsum komplett unterließen. Es wird vermutet, dass Athleten wegen ihres hohen Energiebedarfes durch den Sport auf die schnelle und ständige Verfügbarkeit von Lebensmitteln angewiesen sind (American College of Sports Medicine, 2016), jedoch dadurch nicht zwingend pathologisches Verhalten im Sinne eines Entzugs vorliegt. Von leistungsorientierten Ausdauerathleten werden häufig in kurzer Zeit große Mengen und länger als geplant verzehrt, um die Energiespeicher wieder aufzufüllen (American College of Sports Medicine, 2016). Dieses Verhalten ähnelt zwar den Diagnosekriterien des DSM-5 für Kontrollverlust. Wenn bei den Athleten jedoch kein klinisch signifikantes Leiden vorliegt, sind sowohl der Kontrollverlust, als auch die Entzugssymptome demnach als unproblematisch zu bewerten.

Ein Anteil von 7,6\% der Sportler gab jedoch an, klinisch signifikant unter dem eigenen Essverhalten zu leiden. Auch andere Forschergruppen konnten zeigen, dass Sportler verstärkt unter Essstörungen leiden (Foskett \& Longstaff, 2017; Gulliver et al., 2015). So ist auch der Anteil an psychischen Störungen bei Sportlern vergleichbar mit dem der Bevölkerung (Gulliver, Griffiths, Mackinnon, Batterham, \& Stanimirovic, 2015). Es wird vermutet, dass die hier detektierten Athleten Personen darstellen, die verstärkt Sorgen bezüglich ihres Körpergewichtes und ihrer Figur haben, in diesem Zusammenhang pathologisches Essverhalten zeigen und den Sport nur dazu „missbrauchen“, um ihr Körpergewicht und ihre Figur zu beeinflussen. Weitere Forschungsarbeiten an Sportlern konnten zeigen, dass zudem Depressionen 
und Binge-Episoden zu einem Leidensdruck beitragen können (Hovrud \& De Young, 2015).

Von den Sportlern wurde der „Konsum (von Lebensmitteln) in gefährlichen Situationen“ (2,0 \%) am seltensten erfüllt. Ein möglicher Erklärungsansatz ist, dass für die Athleten eine gefährliche Situation beim Essen wenig relevant erscheint. Gerade bei Ausdauersportlern sind potentielle Gesundheitsrisiken aufgrund von Überernährung, wie Diabetes mellitus Typ 2 oder Herzkreislauferkrankungen, weniger bedeutsam. Stattdessen besteht durch regelmäßige körperliche Aktivität hingegen zumeist ein Gesundheitsnutzen (Warburton, 2006).

Aufgrund der verschiedenen Ausprägungen der Symptome in der Gruppe der Personen mit morbider Adipositas und der Sportler, vermuten wir, dass es bestimmte Symptommuster bei unterschiedlichen Gruppen gibt. Es wird angenommen, dass unterschiedliche Formen der Food Addiction existieren. Für Personen mit niedrigem Körpergewicht könnte eine andere Form von Food Addiction existieren als für Personen mit morbider Adipositas. Möglicherweise zeigen Personen mit niedrigem Körpergewicht ihr pathologisches Essverhalten eher in Form von restriktiven Verhaltensmustern, wohingegen Personen mit Adipositas eher zu einem Überkonsum, Essanfällen und Heißhungerattacken neigen (siehe auch Abbildung 16 - Ausblick).

Um herauszufinden wie sich die Symptomausprägung in den drei deutschen Stichproben verhält, wenn ausschließlich die Untergruppe der Personen mit Food Addiction untersucht wird, wurden Tabelle 15 und Abbildung 13 erstellt. 
Tabelle 15: Ausprägung der YFAS-Symptome von Personen MIT einer Food Addiction in drei deutschen Stichproben und Symptomausprägungen bei Alkoholabhängigkeit zum Vergleich

\begin{tabular}{|c|c|c|c|c|}
\hline YFAS-Symptom & $\begin{array}{c}1 . \\
\text { Bevölkerung } \\
\text { repräsentativ } \\
(\mathrm{n}=82 ; \%)^{\mathrm{a}}\end{array}$ & $\begin{array}{c}2 . \\
\text { Personen } \\
\text { mit } \\
\text { morbider } \\
\text { Adipositas } \\
(\mathrm{n}=19 ; \%)^{\mathrm{b}}\end{array}$ & $\begin{array}{c}3 . \\
\text { Amateur- } \\
\text { Ausdauer- } \\
\text { sportler } \\
(\% ; n= \\
64)^{c}\end{array}$ & $\begin{array}{c}4 . \\
\text { Alkohol- } \\
\text { abhängig } \\
\text { keit }(\%, \mathrm{n} \\
=245)^{\mathrm{d}}\end{array}$ \\
\hline $\begin{array}{l}\text { Einnahme größerer Mengen oder } \\
\text { länger als geplant (amount) }\end{array}$ & 78,0 & 68,4 & 87,9 & 61,1 \\
\hline $\begin{array}{lll}\text { Erfolglose } & \text { Versuche zur } \\
\text { Einschränkung/Kontrolle (attempts) }\end{array}$ & 85,4 & 73,3 & 68,8 & 34,9 \\
\hline Hoher Zeitaufwand (time spent) & 65,5 & 57,9 & 51,6 & 30,7 \\
\hline $\begin{array}{l}\text { Aufgabe on Aktivitäten (activities } \\
\text { given up) }\end{array}$ & 72,0 & 42,1 & 54,7 & 18,7 \\
\hline $\begin{array}{ll}\text { Substanzgebrauch } & \text { trotz } \\
\text { physischer/emotionaler } & \\
\text { Konsequenzen (consequences) } & \end{array}$ & 76,9 & 78,9 & 60,9 & 29,4 \\
\hline Toleranzentwicklung (tolerance) & 52,5 & 52,6 & 57,8 & 52,6 \\
\hline Entzugssymptome (withdrawal) & 81,7 & 57,9 & 62,5 & 18,5 \\
\hline $\begin{array}{lr}\begin{array}{l}\text { Substanzgebrauch } \\
\text { sozialer/persönlicher }\end{array} & \text { trotz } \\
\text { (problems) } & \text { Probleme }\end{array}$ & 72,0 & 57,9 & 64,1 & 38,2 \\
\hline $\begin{array}{l}\begin{array}{l}\text { Versagen } \\
\text { (obligation) }\end{array} \\
\text { bei }\end{array}$ & 68,3 & 68,4 & 57,8 & 24,9 \\
\hline $\begin{array}{l}\text { Substanzgebrauch in } \\
\text { Situationen (physically } \\
\text { situations) }\end{array}$ & 68,3 & 26,3 & 28,1 & 12,7 \\
\hline Craving & 63,4 & 52,6 & 40,6 & 34,7 \\
\hline Leid (Clin. Sign. Impairment) & 100,0 & 100,0 & 100,0 & 100,0 \\
\hline YFAS Food Addiction Prävalenz & 100,0 & 100,0 & 100,0 & 100,0 \\
\hline YFAS Symptomzahl (Spanne 2 - 11) & $\begin{array}{l}7,88 \text { (SD }= \\
2.85)\end{array}$ & $\begin{array}{l}6,37(\mathrm{SD}= \\
2.65)\end{array}$ & $\begin{array}{l}6.27(\mathrm{SD}= \\
2.87)\end{array}$ & \\
\hline
\end{tabular}

Fett gedruckt: im Text diskutiert, ${ }^{a}$ (Hauck, 2017), ${ }^{b}$ (Hauck, 2016), ${ }^{\circ}$ (Hauck, under review), ${ }^{d}$ (Buu et al., 2012) 


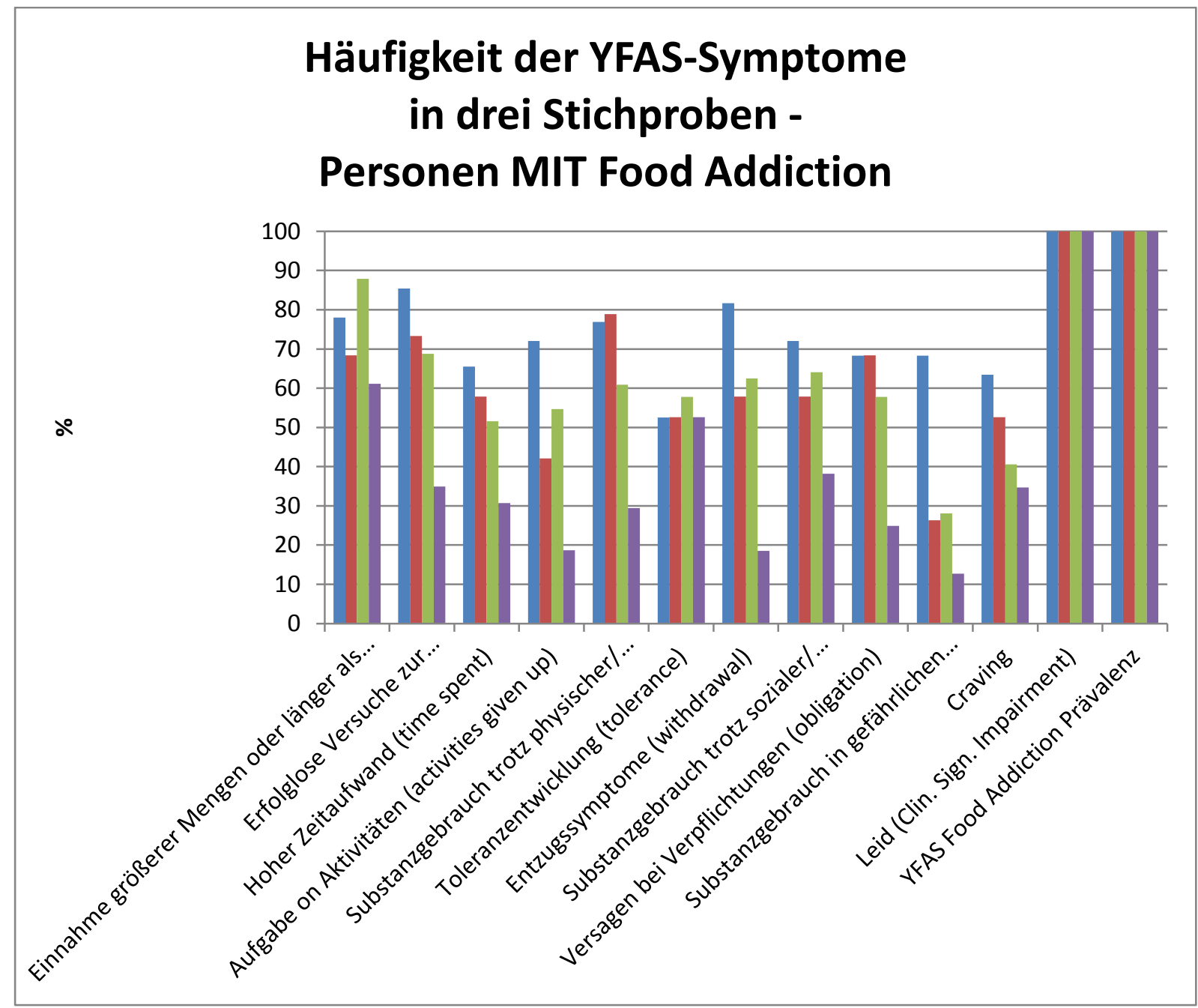

Abbildung 13: Ausprägung der Symptome in drei deutschen Stichproben NUR von Personen MIT Food Addiction (blau = repräsentativ, rot = Klinik, grün = Sportler; zum Vergleich: lila $=$ Alkoholabhängigkeit)

Die Ergebnisse zeigen erwartungskonform, dass die Häufigkeit der Ausprägung der einzelnen Symptome höher ist als in den Gesamtstichproben (vergleiche Abbildungen 12 und 13). Denn wenn nur Personen mit einer Food Addiction eingeschlossen werden, und eine Food Addiction erst ab Erfüllung von mindestens zwei Symptomen plus klinisch signifikanter Beeinträchtigung vorliegt, dann müssen auch die Symptome häufiger ausgeprägt sein.

Personen mit und ohne Food Addiction unterscheiden sich zudem innerhalb der drei Stichproben signifikant voneinander. Dies zeigt, dass Personen mit Food Addiction signifikant andere Essverhaltensweisen aufweisen als Personen ohne Food Addiction. Von Food Addiction Betroffene scheinen demnach ein anderes, und verstärkt pathologisches, Essverhalten aufzuweisen als Nicht-Betroffene. 
Um die eigenen Ergebnisse mit den Symptomausprägungen einer etablierten Suchterkrankung vergleichen zu können, wurden in Tabelle 15 zudem die Symptome bei psychischen und Verhaltensstörungen durch Alkohol exemplarisch mit aufgegriffen. So zeigte sich, dass das Symptom Kontrollverlust für eine Alkoholsucht eines der zentralen Symptome darstellt (Behrendt et al., 2008; Buu et al., 2012; Leeman et al., 2012). Da auch bei Food Addiction der Kontrollverlust mit am häufigsten genannt wurde, legt dies die Vermutung nahe, dass es sich auch bei Food Addiction um eine Suchterkrankung handeln könnte (siehe oben). Die Häufigkeit der Symptomerfüllung war jedoch bei Alkoholabhängigkeit geringer als bei Food Addiction. Dies könnte daran liegen, dass Alkoholsucht sowohl in der milden, wo zwei bis drei Symptome, in der moderaten, wo vier bis fünf Symptome, als auch in der schweren Form, wo sechs oder mehr Symptome plus jeweils klinisch signifikantes Leiden, erfüllt sein müssen, vorliegt. Hingegen liegt die Food Addiction zumeist nur in der schweren Form vor, was eine Erfüllung von mindestens sechs Symptomen plus klinisch signifikantes Leiden bedeutet, und damit eine höhere Zahl an Symptomen erfordert. Möglicherweise ist eine Alkoholsucht zumeist durch die Erfüllung von spezifischen Symptomen, wie Kontrollverlust und Toleranzentwicklung, charakterisiert. Food Addiction weist hingegen verschiedenste Muster in der Symptomerfüllung auf (siehe oben).

Abbildung 13 zeigt, dass für eine YFAS 2.0 Food Addiction das Symptom „klinisch signifikantes Leiden“ zwingend erforderlich ist. So muss das Symptom „Leiden“ zu 100 \% erfüllt sein. Denn ohne ein Leiden wird niemals die Diagnose einer Substanzgebrauchsstörung gestellt werden. Das bedeutet zudem, dass alle Personen, die in den vorliegenden Stichproben eine Food Addiction zeigen, klinisch signifikant unter ihrem Essverhalten leiden. Eine Food Addiction stellt somit einen relevanten Aspekt dar, und sollte demnach nicht vernachlässigt werden.

Auch in den Ergebnissen aus Abbildung 13 zeigt sich, dass in der Repräsentativstichprobe (blau) viele verschiedene Symptome zu einer Food Addiction beitragen können. Hingegen tragen in der klinischen Stichprobe (rot) besonders die vier Symptome "Einnahme größerer Mengen oder länger als geplant", „erfolglose Versuche das Essen einzuschränken/zu kontrollieren“, „Substanzgebrauch trotz sozialer/persönlicher Probleme und „Substanzgebrauch trotz physischer/emotionaler Konsequenzen" zu einer Food Addiction bei. Dieses Ergebnis ist auch wieder vergleichbar zu den Resultaten von Meule (Meule et al., 
2016). In der Sportlerstichprobe ist das dominierende Kriterium die „Einnahme größerer Mengen oder länger als geplant“, was Kontrollverlust bedeutet.

Mit am seltensten erfüllt wurde der „Substanzgebrauch in gefährlichen Situationen“. Es wird vermutet, dass eine gefährliche Situation beim Essen wenig relevant erscheint. So manifestieren sich durch Überessen bedingte Erkrankungen zumeist auch erst nach Jahren und erscheinen in der derzeitigen Situation als wenig oder nicht relevant. Zum Vergleich: auch bei psychischen und Verhaltensstörungen durch Alkohol wird das Kriterium "Substanzgebrauch in gefährlichen Situationen“ selten erfüllt.

Die durchschnittliche Symptomzahl für Food Addiction lag bei den Betroffenen bei 7,88; 6,37 und 6,27 (Tabelle 15). Diese Werte sind höher als in den meisten anderen Studien (Burrows et al., 2018; Pursey et al., 2014). Es wird vermutet, dass dieses Resultat dadurch bedingt ist, dass in den meisten Studien die Gesamtprävalenzen angegeben werden, also sowohl von Personen mit, als auch ohne Food Addiction, und diese Gesamtprävalenzen somit niedriger liegen. Lediglich eine Studie von Meule und Kollegen ermittelte vergleichbare Werte (Meule, von Rezori, \& Blechert, 2014). Diese Studie inkludierte Patienten mit BN. Personen mit BN zeigen pathologisches Essverhalten. Auch bei Personen mit Food Addiction wird pathologisches Essverhalten gemessen. Möglicherweise sind die Werte somit vergleichbar, da sowohl in der Studie von Meule, als auch in unseren Substichproben ausschließlich Personen mit pathologischem Essverhalten eingeschlossen wurden. Dies könnte einen weiteren Hinweis darauf geben, dass durch die YFAS 2.0 pathologisches Essverhalten gemessen wird.

\subsection{Einflussfaktoren auf Food Addiction}

Neben den anthropometrischen Variablen, die nur eine schwache Aufklärung der Varianz für Food Addiction zulassen (siehe 8.3, 8.4 und 8.5), und den YFASSymptomen (siehe 8.6), wurden zudem noch weitere potentielle Einflussfaktoren auf Food Addiction untersucht. Diese sind die rigiden Kontrollstrategien, die gesundheitsbezogene Lebensqualität, die Heißhungerattacken und der Perfektionismus. Diese werden im Folgenden diskutiert. 
Das Konstrukt der Food Addiction wurde zunächst zur Aufklärung von Adipositas konstruiert (Gearhardt et al., 2009b) und ist so auch bei Personen mit Adipositas häufiger zu finden als bei Normalgewichtigen (u.A.: Hauck et al., 2016). Ein zentrales Element bei Adipositas ist die Assoziation mit rigiden Kontrollstrategien (Pudel \& Westenhöfer, 2003). Die rigide Kontrolle ist eine Unterkategorie der kognitiven Kontrolle, und stellt eine der psychologischen Dimensionen des menschlichen Essverhaltens dar (Westenhoefer, Stunkard, \& Pudel, 1999). Es wird vermutet, dass auch zwischen rigider Kontrolle und Food Addiction ein Zusammenhang besteht. Eine Literaturquelle stammt hierzu von Timko und Perone (2005). Diese fand einen Zusammenhang zwischen rigider Kontrolle, hohem BMI und Essstörungen. Unter der Annahme, dass Food Addiction mit bestimmten Ausprägungen von Essstörungen assoziiert sein könnte, wird in der klinischen Stichprobe postuliert, dass auch zwischen rigider Kontrolle, hohem BMI und Food Addiction ein Zusammenhang vorliegen könnte. Diese Hypothese konnte bestätigt werden: Die Summenscores der rigiden Kontrolle konnten die Anzahl an Food Addiction-Symptomen bei Personen mit Adipositas signifikant vorhersagen $\left(\mathrm{R}^{2}=\right.$ 0,$06 ; \mathrm{B}=0,26$ ( 0 bis 0,52 ); $\mathrm{SE}=0,13 ; p=0,05$ ). Es ergab sich eine signifikante Korrelation zwischen den beiden Variablen $\left(r_{p}=0,24 ; p<0,05\right)$. Somit könnte die rigide Kontrolle bei Personen mit morbider Adipositas einen Einflussfaktor auf Food Addiction darstellen. Allerdings konnte das allgemeine lineare Modell nur $6 \%$ der Varianz aufklären, so dass die Ergebnisse noch mit Vorsicht zu interpretieren sind und weiterer Forschungsbedarf in größeren Studien besteht.

Sollte Food Addiction eine Krankheit darstellen, so könnte Food Addiction zu Veränderungen in der gesundheitsbezogenen Lebensqualität führen. Denn die gesundheitsbezogene Lebensqualität ist sowohl in den körperlichen, als auch den psychischen Skalen, negativ mit dem Auftreten von Krankheiten assoziiert (Ellert \& Kurth, 2013). Gesundheitsbezogene Lebensqualität bildet „körperliche, emotionale, mentale, soziale und verhaltensbezogene Komponenten des Wohlbefindens und der Funktionsfähigkeit aus der subjektiven Sicht der Betroffenen“ (Ellert \& Kurth, 2013) ab. Es wird vermutet, dass die gesundheitsbezogene Lebensqualität bei Food Addiction reduziert ist, und Food Addiction somit eine Krankheit darstellt. In der klinischen Stichprobe konnte unsere Hypothese bestätigt werden. Es konnte gezeigt werden, dass Food Addiction in inversem Zusammenhang $\mathrm{zu}$ mentaler Lebensqualität steht $\left(r_{S}=-0,35 ; p<0,01\right)$ und die Anzahl an Food Addiction- 
Symptomen die Summenscores der mentalen Lebensqualität vorhersagen kann $\left(R^{2}\right.$ $=0,11 ; \mathrm{B}=-1,36(-2,36$ bis $-0,36) ; \mathrm{SE}=0,5 ; p<0,01)$. Da die gesundheitsbezogene Lebensqualität durch Food Addiction beeinflusst werden kann, wurde geschlussfolgert, dass Food Addiction möglicherweise ein Krankheitsphänomen darstellen könnte. Zudem geht morbide Adipositas bereits mit psychischen Komorbiditäten und einem starken Leidensdruck einher (Rebscher et al., 2016), so dass die negative Beeinflussung des mentalen Gesundheitszustands durch Food Addiction hoch relevant erscheint und weiterer Forschung bedarf (Hauck et al., 2016).

Von Personen mit Adipositas werden häufig Heißhungerattacken berichtet. Heißhunger ist nach DSM-5 charakterisiert durch den sehr raschen Verzehr einer größeren Menge an Nahrung als normalerweise üblich, begleitet von einem Gefühl des Kontrollverlustes, gefolgt von negativen Emotionen und Völlegefühl (American Psychiatric Association, 2013). Da Heißhunger auch in Zusammenhang zu Kontrollverlust steht, der bei Food Addiction häufig berichtet wurde (Abbildungen 12, 13; Pudel \& Westenhöfer, 2003), soll auch Heißhunger als potentieller Einflussfaktor auf Food Addiction untersucht werden. Es wird vermutet, dass es über die rigide Kontrolle einen Zusammenhang zwischen Food Addiction und Heißhungerattacken gibt. Unsere Hypothese konnte bestätigt werden: die Anzahl an Food AddictionSymptomen konnte in der Klinikstichprobe die Anzahl an Heißhungersymptomen mit einer Varianzaufklärung von $35 \%$, und damit gut, vorhersagen $\left(R^{2}=0,35 ; B=0,51\right.$ $(0,33$ bis 0,69$)$; $\mathrm{SE}=0,09 ; p<0,001)$. Heißhungerattacken und Food Addiction korrelierten hoch positiv $(r=0,59, p<0,001)$ miteinander. Möglicherweise liegen Überschneidungen der beiden Konstrukte Food Addiction und Heißhunger vor. Auch in der Literatur lassen sich Überschneidungen zwischen Heißhungerattacken und pathologischem Essverhalten finden, beispielswiese für BN (de Vries \& Meule, 2016). Aufgrund dieser Befunde kann der in Abbildung 14 gezeigte Zusammenhang zwischen rigider Kontrolle, Heißhungerattacken und Food Addiction, sowie Essstörungen postuliert werden (Abbildung 14). 


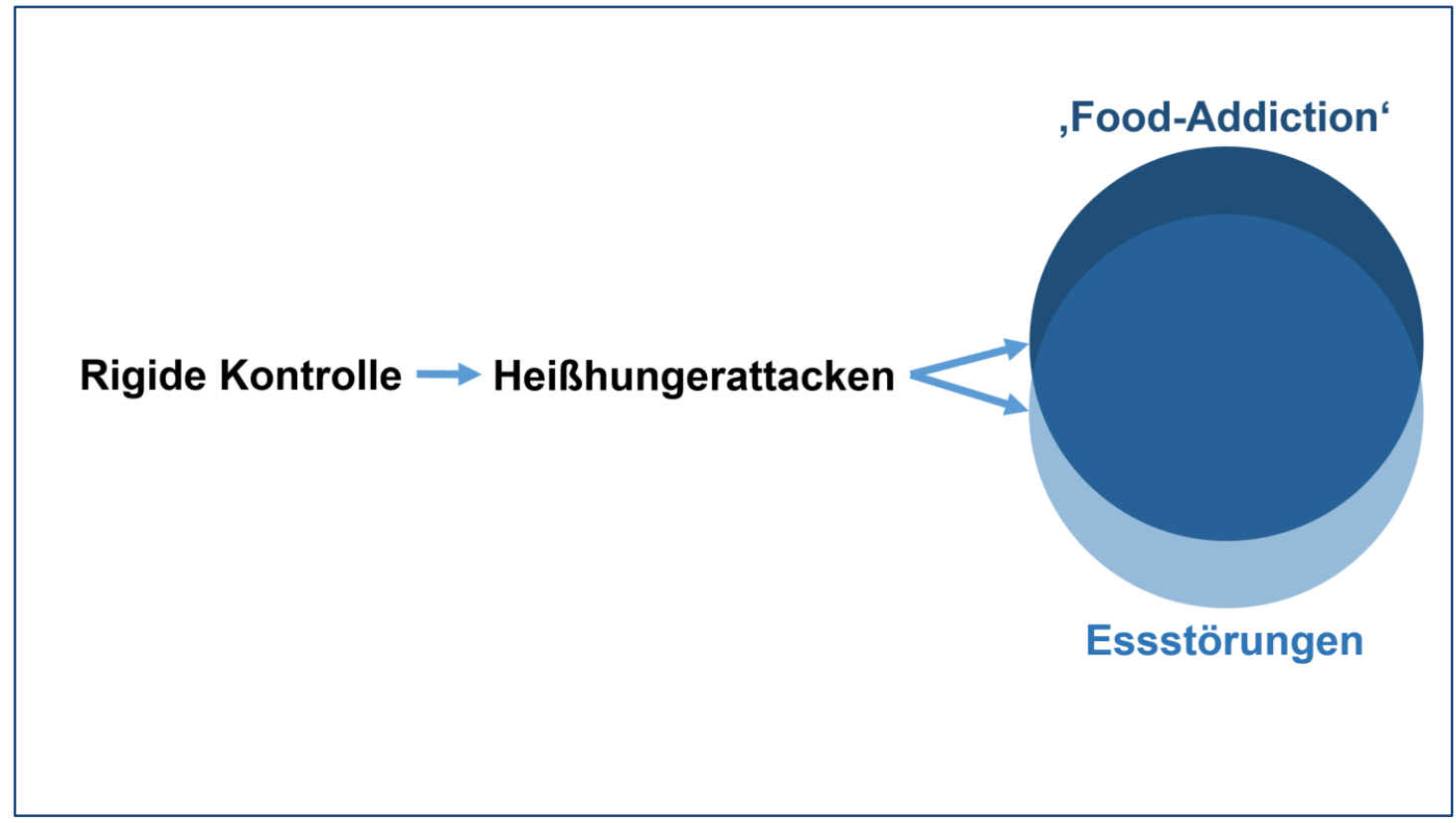

Abbildung 14: Postulierter Zusammenhang zwischen rigider Kontrolle, Heißhungerattacken und Food Addiction, sowie Essstörungen

Einen weiteren möglichen Einflussfaktor auf eine Food Addiction stellt das Persönlichkeitsmerkmal "Gewissenhaftigkeit/Perfektionismus" dar. Denn Perfektionismus ist mit Essstörungen (Bardone-Cone et al., 2007), wie AN (Bastiani, Rao, Weltzin, \& Kaye, 1995), assoziiert. Unter der Annahme, dass Food Addiction pathologisches Essverhalten darstellt, müssten auch Food Addiction und Perfektionismus assoziiert sein. Perfektionismus stellt eines der Persönlichkeitsmerkmale der BIG 5 dar (Ghaderi \& Scott, 2000). Die meisten Menschen zeigen in mindestens einem Bereich ihres Lebens perfektionistische Züge (Stoeber \& Stoeber, 2009). Daher ist es nicht verwunderlich, dass Perfektionismus auch in den Bereichen des Essens und/oder des Sports beschrieben wird. Perfektionismus wird unterteilt in positiven (Streben nach Perfektion) und negativen (Angst vor nicht-perfekter Leistung) Perfektionismus (Stoeber \& Otto, 2006). Positiver Perfektionismus kann beispielsweise zu Leistungssteigerung beitragen (Stoeber, Uphill, \& Hotham, 2009). Wohingegen negativer Perfektionismus zu Depressionen führen kann (Stoeber, 2011). Gerade bei Personen mit großen sportlichen Umfängen, wie Ausdauersportlern, wird ein hohes $\mathrm{Maß}$ an Disziplin gefordert. Parallel steigt häufig jedoch auch die Erwartungshaltung an gute sportliche Leistungen (Stoeber, 2011). Dies kann die Angst vor nicht-perfekter Leistung (= negativer Perfektionismus) erhöhen (Stoeber, 2011). 
Perfektionismus wurde in vorliegender Dissertationsarbeit in der Sportlerstichprobe untersucht, da die Gruppe der leistungsorientierten Ausdauersportler im Vergleich zu Nicht-Sportlern bereits eine Personengruppe mit einer höheren Rate an Perfektionismus darstellt (Dunn, Gotwals, \& Dunn, 2005) und zudem eine höhere Rate an pathologischem Essverhalten aufweist (Sundgot-Borgen \& Torstveit, 2004). Daher schien die Sportlerstichprobe gut geeignet zu sein, um mögliche Einflüsse von Perfektionismus auf Food Addiction zu untersuchen. Es wird folglich vermutet, dass das Vorliegen von negativem Perfektionismus zu einer Food Addiction beitragen kann. Diese Hypothese konnte bestätigt werden. Es zeigte sich, dass die Wahrscheinlichkeit für eine Food Addiction um $122 \%(\operatorname{Exp}(B)=2.217 ; p>.001)$ erhöht ist, wenn ein ausgeprägter negativer Perfektionismus vorliegt (Wald (1) = 17.604, $p$ > .001). Möglicherweise treibt die Angst vor nicht perfekter Leistung, die Athleten demnach so weit, dass sie Lebensmittel missbrauchen, um ihre Ängste zu kompensieren. Wenn bei den Athleten Unsicherheiten in der eigenen Leistung bestehen, die eigenen Leistungen aber durch ein verändertes Körpergewicht optimierbar sind, dann könnte dies zu pathologischem restriktiven Essverhalten und Körpergewichtsreduktion führen. Gerade im Ausdauersport kann ein niedriges Körpergewicht von Vorteil sein (Sudi et al., 2004), so dass in dieser Athletenuntergruppe verstärkt pathologisches Essverhalten mit restriktiven Episoden auftritt (Sundgot-Borgen \& Torstveit, 2004). Auf die einzelnen Athleten sollte daher von den Trainern, Betreuern und Teamkollegen besonderes Augenmerk gerichtet werden.

\subsection{Food Addiction und Sportsucht}

Wie bereits zuvor beschrieben, wird Food Addiction zugeschrieben, pathologisches Essverhalten im Kontext von Sucht darzustellen. In vielen Therapiekonzepten für pathologisches Essverhalten wird körperliche Aktivität als eine der Therapiemethoden eingesetzt (DAG e.V., 2014; Deutsche Gesellschaft für Psychosomatische Medizin und Psychotherapie (DGPM), 2010). Denn durch Sport kann sowohl Gewicht reduziert werden - besonders bedeutsam ist dies im Kontext von Adipositas -, als auch die Körperwahrnehmung verbessert, und eine Regelmäßigkeit im Alltag der Betroffenen etabliert werden (DAG e.V., 2014). Auch wenn körperliche Bewegung in Therapieprogrammen zumeist eine positive Wirkung aufweist, gibt es bei bestimmten Patientengruppen auch negative Auswirkungen von 
sportlicher Aktivität (Zeeck et al., 2013; Zeeck \& Schlegel, 2012). So missbrauchen Personen mit Essstörung den Sport teilweise zur weiteren Gewichtsoptimierung, der bis hin zu sportsüchtigem Verhalten führen kann (Zeeck et al., 2013). Es ist zudem bereits bekannt, dass Suchterkrankungen in Individuen koexistieren können (NIDA, 2014; Sussman, 2017; Volkow, 2010) und Essstörungen häufig mit Suchterkrankungen einhergehen (Calero-Elvira et al., 2009; Treasure et al., 2010).

Unter der Annahme, dass Food Addiction eine Form süchtigen Essverhaltens darstellt, und auch eine Sucht im Kontext von Sport existiert, könnten diese Koexistenzen gerade bei Ausdauerathleten (hohe sportliche Umfänge, hoher Bedarf an Nahrungsenergie und niedriges Körpergewicht) vorliegen. Rund ein Drittel der untersuchten Ausdauerathleten wies in der Sportlerstichprobe sportsüchtiges Verhalten auf (Hauck et al., n.d.). Personen die sich exzessiv mit Sport beschäftigen, könnten demnach auch dazu tendieren, sich exzessiv mit Essen zu beschäftigen um zum Beispiel ihr Körpergewicht zu reduzieren - und vice versa (Zeeck \& Schlegel, 2012). Darauf basierend vermuteten wir, dass bei Personen mit Sportsucht auch das Risiko für eine Food Addiction erhöht ist. Diese Hypothese konnte in einem hochsignifikanten Zusammenhang zwischen Sportsuchtgefährdung und Food Addiction und kleiner Effektstärke bestätigt werden $\left(X^{2}=16,250\right.$, df (1), $p<0,001$, Cramers Phi $=0,126, p<0,001)$. Die Ergebnisse lassen vermuten, dass ein signifikanter Anteil an leistungsorientierten Ausdauersportlern pathologisches Essverhalten in Form einer Food Addiction zeigt und darunter klinisch signifikant leidet. Diese Zusammenhänge sprechen für die Hypothese der Koexistenz verschiedener Suchterkrankungen von Sussman (2017; siehe Kapitel 0 Einführung). Möglicherweise versuchen die Athleten mittels Sport ihre Figur und ihr Körpergewicht zu optimieren, gelangen hierdurch jedoch in eine Essstörung. Dies kann zu einer Spirale aus Sportsucht und pathologischem Essverhalten führen. Der Zusammenhang könnte zudem durch negativen Perfektionismus mitbedingt sein. Durch die Angst vor negativer Leistung im Sport kann es zu vermehrtem Training mit gleichzeitiger restriktiver Energieaufnahme kommen. Gerade hier sind Betreuer, Trainer und Teamkollegen gefragt. 


\section{9 Überschneidung Food Addiction und Essstörungen}

Im Diskussionsteil wurde häufig auf mögliche Überschneidungen von Food Addiction mit den bereits etablierten Essstörungen, wie AN, BN oder BED, hingewiesen (Burrows et al., 2018; Davis, 2016; Gearhardt et al., 2014; Gearhardt, White, et al., 2011; Ruddock, Christiansen, Halford, \& Hardman, 2017). Jedoch liegen Überlappungen nicht zu $100 \%$ vor. Food Addiction tritt somit nicht zu $100 \%$ koexistent zu Essstörungen auf (de Vries \& Meule, 2016; Granero et al., 2014; Meule et al., 2014). Food Addiction wird daher nicht als Facette von, sondern mit Parallelen zu, Essstörungen angesehen (Davis, 2016; Ruddock et al., 2017). Aufgrund der erheblichen potentiellen Überschneidungen könnten deshalb auch Symptome, die bei Personen mit Essstörungen vorhanden sind, auch bei Personen mit Food Addiction zu finden sein. Aufgrund der unterschiedlichen Ausprägungsmuster der einzelnen Symptome (Kapitel 8.6) für Personen mit morbider Adipositas und Ausdauersportlern wurden auch unterschiedliche Wege der Erfüllung einer Food Addiction vermutet. So könnten bei Personen mit morbider Adipositas Heißhungerattacken und Kontrollverlust zu einem Überessen und einer Food Addiction führen - ähnlich BES (Binge-Eating Störung) oder ESS-NNB (nicht näher bezeichnete Essstörung). Bei Sportlern wird eine kontinuierliche Restriktion mit subjektiv empfundenen Kontrollverlust vermutet, der zu Food Addiction beiträgt ähnlich den Charakteristika von AN, BN oder ESS-NNB.

In vorliegender Dissertationsschrift wurden psychometrisch validierte Fragebögen in den Studien eingesetzt, diese lassen keine Diagnosen zu. Zudem wurde die Essstörungspathologie nicht explizit in den Fragebögen mit erhoben, so dass in der Dissertationsarbeit keine finalen Aussagen über Zusammenhänge zwischen Food Addiction und Essstörungen getroffen werden können. Auf Basis der eigenen Ergebnisse wurden jedoch Vermutungen angestellt. Diese stellen ein Forschungsdesiderat dar.

Abbildung 15 zeigt die Prävalenz von Food Addiction nach BMI-Kategorie und potentielle Überschneidungen von Food Addiction in den einzelnen BMI-Gruppen mit den etablierten Essstörungen AN, BN, BES, ES-NNB. 


\section{Prävalenz Food Addiction nach BMI-Kategorie und potentielle Überschneidungen mit Essstörungen}

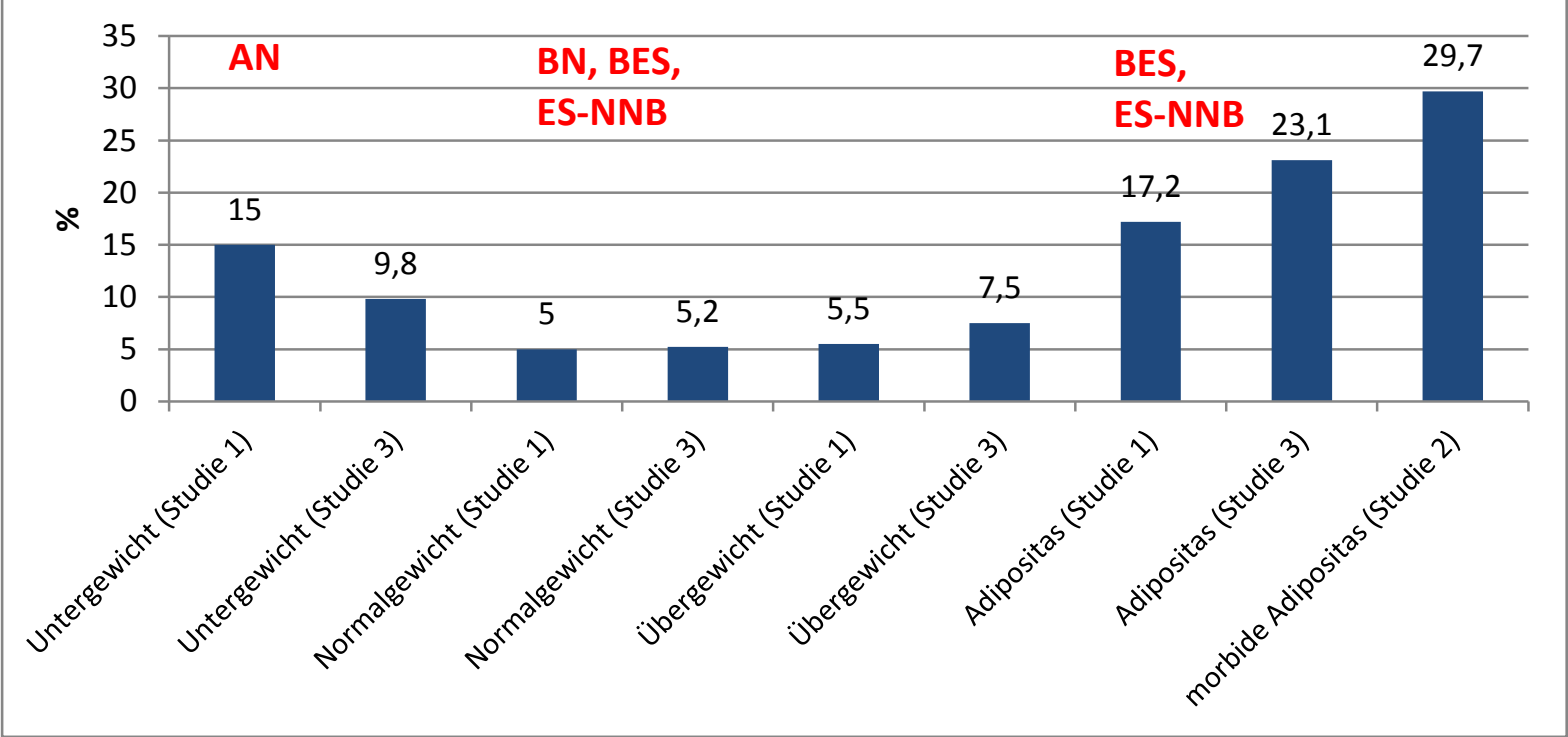

Abbildung 15: Prävalenz Food Addiction nach BMI-Kategorie und potentielle Überschneidungen mit Essstörungen (AN = Anorexia Nervosa, BN = Bulimia Nervosa, $\mathrm{BES}=$ Binge-Eating Störung, ES-NNB = nicht näher bezeichnete Essstörung)

Da eine Food Addiction nur bei $17 \%$ aller von Adipositas Betroffenen in Deutschland vorliegt (Hauck et al., 2017) ergibt sich die Frage, ob es sich bei Food Addiction um einen speziellen Phänotyp von Adipositas handelt. Personen mit Adipositas zeigen häufig die Essstörung BED (Darby, 2009). Möglicherweise könnte pathologisches Essverhalten bei Personen mit Adipositas auch durch BED, statt durch Food Addiction, erklärt werden. BED und Food Addiction teilen so beispielsweise das Charakteristikum des „zwanghaften Überessens“ (Davis, 2016). BED ist nach Davis (2016) jedoch den psycho-behavioralen Erkrankungen zuzuordnen, wohingegen Suchterkrankungen wie Food Addiction sich selbst erhaltende klinische Phänomene darstellen (Davis, 2016). Food Addiction ist demnach nicht gleichzusetzten mit einer BED (Davis, 2016). So kann Food Addiction auch ohne die Koexistenz einer BED vorliegen (Davis, 2016). Möglicherweise könnte das Überessen bei Food Addiction in Form von Grazing entstehen (Davis, 2016; Heriseanu, Hay, Corbit, \& Touyz, 2017; Saunders, 2004). Grazing ist definiert als fortwährender Konsum kleiner 
Nahrungsmengen über eine lange Zeit hinweg, begleitet von subjektivem Kontrollverlust (Saunders, 2004). Auch bei anderen Suchterkrankungen, wie der Alkoholsucht, lassen sich spezielle Formen des kontinuierlichen Konsums finden (Rehm et al., 2003). Somit könnte Food Addiction bei Adipositas einen speziellen Phänotyp darstellen, mit dem Charakteristikum des kontinuierlichen Überessens an kleinen Lebensmittelmengen.

Die „Grazing-Hypothese“ von Davis (2016) scheint auf den ersten Blick den Ergebnissen aus der Klinikstichprobe zu rigider Kontrolle und deren Assoziation zu Food Addiction (Kapitel 4) zu widersprechen. Es wird jedoch vermutet, dass Personen mit morbider Adipositas und rigidem Kontrollverhalten durch eine fortwährende gedankliche Überbeschäftigung mit Essen (=FA), unbewusst kontinuierlich kleine Mengen konsumieren (= Grazing), zum Beispiel Kekse am Schreibtisch, obwohl sie sich das Essen, zum Beispiel großer Hauptmahlzeiten wie das Frühstück, eigentlich verbieten (= rigide Kontrolle). Dies könnte zu einem Leidensdruck beitragen (=FA). Dieses Leiden wird mittels YFAS 2.0 abgefragt. So könnte dies möglicherweise auch durch das Messinstrument bedingt sein.

\subsection{Food Addiction-Raten im Verlauf}

Food Addiction misst pathologisches Essverhalten (Gearhardt et al, 2009). Es stellt sich die Frage, ob sich Food Addiction im Zeitverlauf verändert. Derzeit liegen wenige Studien mit Verlaufsdaten von Food Addiction vor. Drei Studien in der bariatrischen Chirurgie zeigen, dass sich Food Addiction im ersten Jahr nach bariatrischer Operation reduzierte (Sevinçer, Konuk, Bozkurt, \& Coşkun, 2016), bis hin zu einer vollständigen Remission nach Operation (Pepino, Stein, Eagon, \& Klein, 2014). Food Addiction stellt zudem einen Prädiktor für erneute Gewichtszunahme nach Operation dar (Ivezaj, Wiedemann, \& Grilo, 2017; Yanos, Saules, Schuh, \& Sogg, 2015). Eine Studie an Personen mit BN konnte eine Reduzierung der Food Addiction-Rate nach sechs-wöchiger Intervention feststellen (Hilker et al., 2016). Die derzeit größte prospektive Untersuchung zu Food Addiction und in einem konservativen Gewichtsreduktionsprogramm zeigte keinerlei Einfluss von Food Addiction auf den Gewichtsreduktionserfolg (Lent, Eichen, Goldbacher, Wadden, \& Foster, 2014). Vorliegende Dissertationsschrift kann keine Aussagen zu Food Addiction im Zeitverlauf treffen, da die Erhebungen immer nur zu einem bestimmten 
Zeitpunkt durchgeführt wurden. Zukünftige Studien sind hierfür jedoch bereits in Planung.

\subsection{Kritik am Konzept Food Addiction}

Das Konstrukt der Food Addiction ist ein recht junges, welches daher noch zahlreiche Limitationen und Unklarheiten aufweist. So berichten kritische Reviews Defizite des Konstrukts im Bereich neurobiologischer (Westwater, Fletcher, \& Ziauddeen, 2016; Ziauddeen, Farooqi, \& Fletcher, 2012), phänomenologischer (Albayrak, Wölfle, \& Hebebrand, 2012; Hebebrand et al., 2014) und diagnostischer Aspekte (Long, Blundell, \& Finlayson, 2015; Ruddock et al., 2017).

Bisher wurde zudem keine suchterzeugende biochemische Eigenschaft in Lebensmitteln gefunden, die explizit für Food Addiction verantwortlich gemacht werden konnte. Dies ist unter anderem dadurch bedingt, dass ein großer Teil der Lebensmittel aus vielen verschiedenen Inhaltsstoffen besteht, von denen bisher nicht ein einzelner als suchterzeugend definiert werden konnte (Ahmed et al., 2013; Finlayson, 2017; Pursey, Davis, \& Burrows, 2017; Ruddock et al., 2017). Eine der positiven Eigenschaften von Lebensmitteln ist, dass sie natürlicherweise eine intrinsische Belohnungswirkung besitzen, um das Überleben der Menschen zu sichern (Ahmed et al., 2013; Gold, Frost-Pineda, \& Jacobs, 2003). Statt als toxisch, wie andere suchterzeugende Substanzen, sind Lebensmittel überlebenswichtig. Besonders bei Hungergefühlen wird das Belohnungszentrum des Gehirns durch Nahrungsaufnahme aktiviert. Daher liegt es nahe, eine suchtartige Wirkung von Nahrungsmitteln zu vermuten (Hebebrand et al., 2014). So stellt sich die Frage nach einer Pathologisierung von grundsätzlich natürlichen Verhaltensweisen durch das Konzept der Food Addiction. Es wird argumentiert, dass es jedoch evidenzbasierte Hinweise auf das Vorliegen einer Food Addiction bei bestimmten Personen gibt, die klinisch signifikant unter ihrem Essverhalten leiden. Dieses Leiden wird nicht durch die etablierten Essstörungen mit abgebildet, so dass es ein weiteres Konstrukt von pathologischem Essverhalten geben muss, wie beispielsweise eine Food Addiction (unter Anderem: Gearhardt, Davis, et al., 2011; Pursey et al., 2017; Schulte \& Gearhardt, 2017). Daher wird für die Existenz einer Food Addiction plädiert - bis ein valides Gegenargument vorliegt. 
Auch die vermeintliche Medikalisierung der grundlegend natürlichen Nahrungsaufnahmeprozesse wurde kritisiert (Blaszczynski, 2015; Finlayson, 2017; Fraser, 2013). Laut Finlayson (2017) kann die Nutzung medizinischer Fachsprache im Kontext von Essen zu einem falschen Verständnis von Übergewicht/Adipositas führen. Denn das Wort Sucht impliziert Krankheit und moralische Missbilligung (Finlayson, 2017). Übergewicht kann jedoch sowohl durch Überessen, als auch pre/perinatal oder umweltvermittelt ohne jeglichen Einfluss von Nahrung entstehen (Epstein \& Shaham, 2010). Food Addiction soll deshalb auch nicht als Entschuldigung für un-physiologisches Überessen dienen, denn individuelle Entscheidungsmöglichkeiten sind trotz allem gegeben (Hebebrand et al., 2014). So wird auch nicht jede Person, die bestimmte hochverarbeitete Lebensmittel konsumiert, süchtig nach diesen. Und nur ein bestimmter Prozentsatz der Bevölkerung weist eine Food Addiction auf (Hauck et al., 2017), obwohl hochverarbeitete Lebensmittel, die als suchtauslösend gelten (Schulte et al., 2015), von vielen Menschen konsumiert werden (Kearney, 2010). Diese Aussagen bleiben konsistent wenn man davon ausgeht, dass für die Ausbildung von Food Addiction weitere Voraussetzungen, wie in Abbildung 16 gezeigt, erfüllt werden müssen.

In Gesellschaften in denen Drogen kriminalisiert werden, werden Suchterkrankte zudem häufig als Kriminelle bezeichnet und erfahren soziale Benachteiligung, Verurteilung und Leiden. Die Idee des Konzepts der Food Addiction hat jedoch die Intention, genau diese Aspekte zu reduzieren. Finlayson (2017) vermutet, dass das Konzept hingegen unbewusst genau anders herum wirkt und so beispielsweise zu weiterer Stigmatisierung beitragen könnte (Finlayson, 2017).

Zudem wird die Übertragbarkeit der DSM-Symptome auf das Essverhalten kritisch diskutiert (Albayrak, Kliewer, Föcker, Antel, \& Hebebrand, 2015). Laut Meule und Gearhardt (2014a) ist eine grundsätzliche Übertragbarkeit gegeben. Welche Kriterien des DSM-5 jedoch in Bezug zu Essverhalten relevant sind, muss noch erforscht werden (Curtis \& Davis, 2014). Bei anderen Drogen, wie Inhalantien, Halluzinogenen oder Koffein, werden beispielsweise die Symptome „Entzug“ oder „Toleranzentwicklung“ nicht einmal als diagnostische Kriterien aufgeführt. Dies wirft die Frage auf, ob diese Kriterien für die Operationalisierung von Food Addiction demnach überhaupt benötigt werden (Albayrak et al., 2015). 
Viele Erkenntnisse im Bereich Food Addiction stammen zudem noch aus Tierund nicht aus Humanstudien (Avena, Bocarsly, Rada, Kim, \& Hoebel, 2008; Avena, Long, \& Hoebel, 2005; Avena, Rada, et al., 2008; Hoebel, Avena, Bocarsly, \& Rada, 2009; George F. Koob, 2012). Deren Übertragbarkeit auf den Menschen könnten zu Fehlinterpretationen führen (Hebebrand et al., 2014).

Vorliegende Dissertationsarbeit war nicht dazu konzipiert, zu neurobiologischen Aspekten beizutragen, wollte jedoch auf phänomenologischer Basis neue Aspekte und Assoziationen bestimmter Variablen zu Food Addiction aufzeigen.

\subsection{Kritik an der Yale Food Addiction Scale}

Neben dem Konzept der Food Addiction wird auch das Erfassungstool, die YFAS, kritisiert. So erfragt diese laut Hebebrand und Kollegen (2014) nicht die eigentlich beabsichtigte substanzbezogene Sucht, sondern stattdessen das individuelle Essverhalten einer Person (Hebebrand et al., 2014). Hebebrand, Ruddock und Kollegen (2017) propagierten auch, dass beim Essen möglicherweise keine Sucht im Sinne einer Substanzgebrauchsstörung vorliegen könnte, sondern eine verhaltensbasierte Sucht in Form einer „Eating Addiction“ (Hebebrand et al., 2014; Ruddock et al., 2017). Ruddock und Kollegen entwickelten daraufhin ein neues Erhebungsinstrument, die „Addiction-like Eating Behaviour Scale“ (Ruddock et al., 2017). Dieser Fragebogen wurde jedoch ebenfalls kritisiert, da er möglicherweise keine neuen Dimensionen des Essverhaltens misst. Zudem basiert der neue Fragebogen nicht auf den Kriterien des DSM-5, sondern auf Laienaussagen, was die Validität des Fragebogens in Frage stellt (Vainik \& Meule, 2017). Weitere Forschergruppen postulierten die stärkere Fokussierung auf Liking und Wanting, und entwickelten daraufhin den „Leeds Food Preference Questionnaire“ (Alkahtni, Dalton, Abuzaid, Obeid, \& Finlayson, 2016; Dalton \& Finlayson, 2014).

Es bleibt daher noch Forschungspotential für die Zukunft offen, sowohl im Hinblick auf das Konstrukt der Food Addiction an sich, zu Food Addiction versus Eating Addiction, zum Erfassungsinstrument YFAS 2.0, als auch zur Abgrenzung und Überschneidung von Food Addiction mit etablierten Essstörungen. 


\section{Schlussfolgerung und Ausblick}

Im abschließenden neunten Kapitel wird eine Schlussfolgerung zum Thema gezogen, und ein Ausblick auf zukünftige Forschungsaspekte gegeben.

Das Konzept der Food Addiction postuliert einen Zusammenhang zwischen einer Suchterkrankung und dem Konsum hochprozessierter Lebensmittel. Bei der Manifestation einer Suchterkrankung sind die Veränderungen im Gehirn bereits großteils aufgeklärt und bekannt (siehe Teil 1 Einleitung). Unklar ist jedoch noch, wann ein Substanzkonsum, beziehungsweise eine Gewohnheit, in Sucht übergeht und welche Veränderungen sich im Gehirn in diesem Verlaufsprozess zeigen (Wise \& Koob, 2014). Hier liegen noch unscharfe Grenzen und Übergänge vor (Sussman \& Sussman, 2011). Es besteht daher noch allgemeiner Forschungsbedarf im Kontext von Suchterkrankungen.

Seit den 2000er Jahren wird verstärkt am Konstrukt der Food Addiction geforscht, jedoch steht dieses noch am Beginn seiner Forschungsreise. Obgleich noch nicht abschließend geklärt ist, ob eine Food Addiction existiert, so konnte die im Rahmen von Food-Addiction generierte Forschung, beispielsweise an den Mechanismen von Liking, Wanting und den Dopaminkreisläufen, einen entscheidenden Teil dazu beigetragen, die physiologischen Abläufe von hedonischem Essverhalten zu verstehen. Zudem konnte die Forschung zeigen, dass diese Prozesse Risikofaktoren für einen Lebensmittelüberkonsum und Essstörungen darstellen könnten (Finlayson \& Dalton, 2012). Aus diesem Grund kann der Food Addiction-Forschung ein besonderer Stellenwert zugeschrieben werden.

Nach derzeitigen Forschungserkenntnissen existiert noch berechtigte Kritik am Konstrukt (unter Anderem: Finlayson, 2017; Hebebrand et al., 2014; Ruddock et al., 2017; Ziauddeen et al., 2012). Da Essen überlebenswichtig ist und ein menschliches Grundbedürfnis darstellt, stellen sich viele Forscher die Frage, ob mit der Food Addiction-Forschung natürliches menschliches Verhalten pathologisiert wird. Dagegen spricht, dass evidenzbasierte Hinweise auf das Vorliegen einer Food Addiction existieren (unter anderem: Gearhardt, Davis, et al., 2011; Pursey et al., 2017; Schulte \& Gearhardt, 2017). So leiden Personen mit Food Addiction klinisch signifikant unter ihrem Essverhalten. Durch die etablierten Essstörungen kann das Leiden nicht vollständig abgebildet werden. Es gibt deutlichen Forschungsbedarf, ob Food Addiction, wenn diese nicht mit Essstörungen überlappt, eine eigenständige 
Störung ist, der mit speziellen Maßnahmen vorgebeugt werden kann oder die mit speziellen Therapiestrategien kuriert werden kann.

Insbesondere Personen mit Untergewicht und Adipositas scheinen von Food Addiction betroffen zu sein, zudem Frauen eher als Männer, sowie jüngere Personen eher als ältere (siehe Kapitel 3, 4 und 5; Hauck et al., 2016; Hauck et al., 2017; Hauck et al., n.d.). Die am häufigsten erfüllten Symptome sind bei Personen mit Adipositas der Kontrollverlust und der Substanzgebrauch trotz sozialer/persönlicher Probleme, und trotz physischer/emotionaler Probleme. Zudem leiden viele signifikant unter ihrem Essverhalten. Sportler berichten dagegen am häufigsten einen Kontrollverlust, sowie Entzugssymptome. Dies muss bei den Sportlern nicht unbedingt pathologische Auswirkungen haben, sondern kann durch einen sportbedingt hohen Energiebedarf erklärt werden. Alle Personen mit einer Food Addiction erfüllen jedoch zudem definitionsgemäß das Symptom „klinisch signifikantes Leiden“, was pathologisches Essverhalten darstellt. Bei Personen mit morbider Adipositas können rigide Kontrollmechanismen zudem Food Addiction vorhersagen. Zudem kann das Vorliegen von Food Addiction die Summenscores der mentalen Lebensqualität, sowie die Anzahl an Heißhungersymptomen vorhersagen. In der Sportlerstichprobe konnte zudem eine Assoziation zwischen negativem Perfektionismus und Food Addiction gefunden werden. Wenn bei den Sportlern zudem das Risiko für eine Sportsuchtgefährdung vorlag, dann erhöhte dies die Wahrscheinlichkeit für eine Food Addiction. Da viele der untersuchten Variablen sowohl bei Food Addiction, als auch bei etablierten Essstörungen, wie AN, BN oder BED, auftreten, wurden Überlappungen vermutet. Mögliche Überschneidungen sind vorhanden, jedoch kann Food Addiction nicht vollständig von einer der etablierten Essstörungen abgebildet werden, so dass von Parallelen - und nicht Gleichheit zwischen Food Addiction und Essstörungen ausgegangen wird. Auch wenn Food Addiction keine universale Erklärung für die steigenden Zahlen von Adipositas liefert - wofür das Konstrukt ursprünglich konzipiert war - so muss dennoch konstatiert werden, dass diese Diagnose bei $17 \%$ aller von Adipositas Betroffenen in Deutschland vorliegt (Hauck et al., 2017). Daraus ergibt sich die Frage, ob es sich hier um einen speziellen Phänotyp von Adipositas handelt, und ob es eine Überschneidung zwischen Food Addiction und Essstörungen gibt. Hier ist weitere Forschung geplant, ebenso wie zur Entwicklung von Food Addiction im Zeitverlauf. 
Mittels der eigenen erhobenen Studiendaten und Informationen aus der Literatur (siehe Kapitel 3 bis 8) wurde eine Abbildung (Abbildung 16) erstellt, die einen möglichen Zusammenhang zwischen persönlichen Verhaltensweisen (Brunault et al., 2018), Essstörungen und Food Addiction aufzeigt. Diese Abbildung kann als Gedankenkonstrukt für zukünftige Studien gesehen werden.

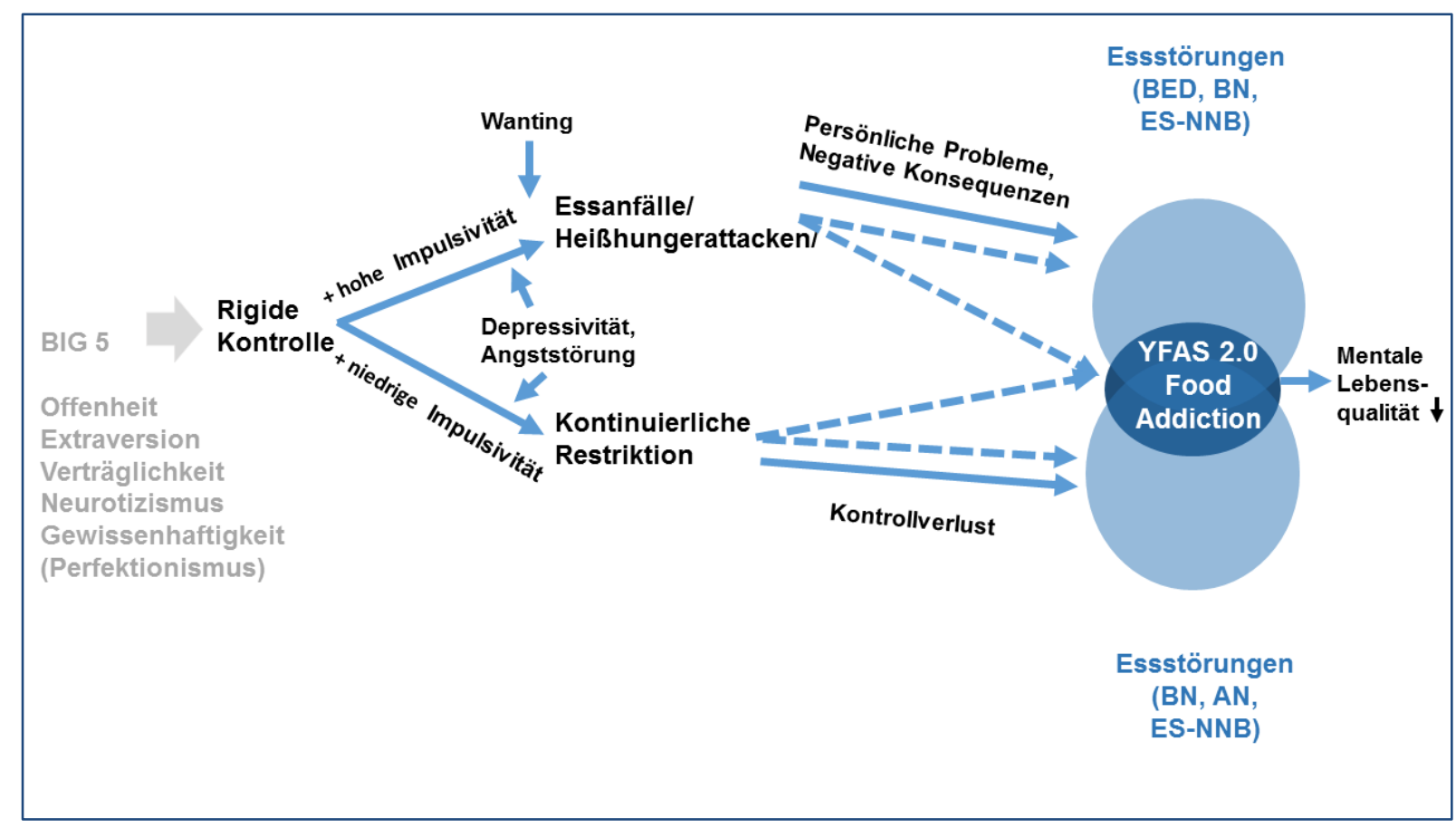

Abbildung 16: Möglicher Zusammenhang zwischen Persönlichkeitseigenschaften, Food Addiction und Essstörungen ( $\mathrm{AN}$ = anorexia nervosa, $\mathrm{BN}=$ bulimia nervosa, $\mathrm{BES}=$ Binge-Eating-Störung, ES-NNB = nicht näher bezeichneten Essstörungen)

Es wird vermutet, dass es zwei unterschiedliche Wege zur "Erfüllung" einer Food Addiction gibt: Personen mit Normal- und Untergewicht scheinen andere Verhaltensweisen aufzuweisen als Personen mit Adipositas und so auf unterschiedlichen Wegen zur Pathogenese von suchtartigem Essverhalten zu gelangen (siehe Abbildung 16). Die genauen Mechanismen sollten in weiteren Studien erforscht werden.

Unklar ist derzeit, ob Food Addiction eher den Substanzgebrauchsstörungen oder den Verhaltenssüchten zuzuordnen ist, oder gar eine eigene Entität, wie eine neue Essstörung, darstellt. Dennoch oder gerade deshalb ist die weitere Erforschung 
von Food Addiction sinnvoll. Dabei geht es vor allem um die Frage von klinischer Relevanz und sozioökonomischen Folgen. Sollten sich bestimmte Lebensmittel mit hohem Verarbeitungsgrad und einer Kombination aus Kohlenhydraten und Fetten als verlässlich störungsauslösend für einen bestimmten Teil der Bevölkerung mit entsprechender Disposition herausstellen (Hypothese Substanzgebrauchsstörung), so muss auch die Frage beantwortet werden, wie Betroffene geschützt werden können. Wenn von einer Verhaltenssucht ausgegangen wird, müssen die Rahmenbedingungen so modifiziert werden, dass vulnerable Personen auf physiologische Weise essen können, ohne ihr Essverhalten in pathologischer Weise zum Erzwingen positiver Gefühle zu missbrauchen. Dazu ist eine genaue Kenntnis der Faktoren notwendig, die eine pathologische Konversion des physiologischen Verhaltens begünstigen. Auch Food Addiction als neue Essstörung würde entsprechende Forschung zur Prävention und Therapie implizieren.

Zukünftig sollen eine eindeutigere Definition von Food Addiction formuliert, beeinflussende Variablen auf Food Addiction erforscht, und eine Abgrenzung zu den etablierten Essstörungen gegeben werden. Unklar ist ferner, ob von Food Addiction Betroffene separate Therapieangebote mit Berücksichtigung von suchtartigem Essverhalten (Meseri et al., 2016) benötigen, und/oder ob sie von etablierten Therapieverfahren zur Behandlung von Essstörungen profitieren können. Einen Therapieansatz könnte das Konzept des "Mindful Eating" und Achtsamkeit beim Essen (Peitz \& Warschburger, 2017) darstellen. Hierbei spielt die flexible Kontrolle eine wichtige Rolle (Westenhoefer, Stunkard, \& Pudel, 1999). Die flexiblen Kontrollstrategien der kognitiven Kontrolle geben Raum für Anpassungen des Essverhaltens an die individuellen Gegebenheiten, ohne Schuldgefühle zu generieren (Westenhoefer et al., 1999). Flexible Kontrolle ist zudem assoziiert mit geringerem Körpergewicht, besserem Gewichtsreduktionserfolg und niedrigerer Essstörungspathologie (Pudel \& Westenhöfer, 2003; Westenhoefer et al., 1999). Einen weiteren bedeutenden Aspekt in Präventions- und Therapieansätzen sollte der Genuss beim Essen darstellen. So konnte in der Genussstudie (siehe Kapitel 7) gezeigt werden, dass selbstbezeichnete Genießer eine höhere Lebenszufriedenheit und ein höheres Wohlbefinden aufweisen als Nicht-Genießer (Hauck \& Ellrott, 2017b). Möglicherweise könnte ein spezielles Genuss- und Achtsamkeitstraining daher auch bei Food Addiction eingesetzt werden. 


\section{Literaturverzeichnis Teil 3 - Diskussion}

Ahmed, S. H., Avena, N. M., Berridge, K. C., Gearhardt, A. N., \& Guillem, K. (2013). Food Addiction. In D. W. Pfaff (Ed.), Neuroscience in the 21st Century (pp. 2833-2857). New York, NY: Springer New York. Retrieved from http://link.springer.com/10.1007/978-1-4614-1997-6_110

Albayrak, Ö., Kliewer, J., Föcker, M., Antel, J., \& Hebebrand, J. (2015). Food Addiction: Nahrungsmittelabhängigkeit oder Ess-Verhaltenssucht? Zeitschrift für Kinder- und Jugendpsychiatrie und Psychotherapie, 43(3), 173-183. https://doi.org/10.1024/14224917/a000355

Albayrak, Ö., Wölfle, S. M., \& Hebebrand, J. (2012). Does Food Addiction Exist? A Phenomenological Discussion Based on the Psychiatric Classification of Substance-Related Disorders and Addiction. Obesity Facts, 5(2), 165-179. https://doi.org/10.1159/000338310

Alkahtni S. A., Dalton M., Abuzaid O., Obeid O., \& Finlayson G. (2016). Validation of the Leeds Food Preference Questionnaire in Arabs. Asia Pacific Journal of Clinical Nutrition, 25(2), 257-264. https://doi.org/10.6133/apjcn.2016.25.2.07

American College of Sports Medicine. (2016). Nutrition and Athletic Performance: Medicine \& Science in Sports \& Exercise, 48(3), 543-568. https://doi.org/10.1249/MSS.0000000000000852 American Psychiatric Association (Ed.). (2013). Diagnostic and statistical manual of mental disorders: DSM-5 (5. ed). Washington, DC: American Psychiatric Publ.

American Psychiatric Association, \& American Psychiatric Association (Eds.). (2009). Diagnostic and statistical manual of mental disorders: DSM-IV-TR (4. ed., text revision, 13. print). Arlington, VA: American Psychiatric Assoc.

Anonyme Alkoholiker Interessengemeinschaft e. V. (2018, February 2). Anonyme Alkoholiker im deutschsprachigen Raum. Retrieved February 2, 2018, from https://www.anonymealkoholiker.de/ 
Attia, E., Becker, A. E., Bryant-Waugh, R., Hoek, H. W., Kreipe, R. E., Marcus, M. D., ... Wonderlich, S. (2013). Feeding and Eating Disorders in DSM-5. American Journal of Psychiatry, 170(11), 1237-1239. https://doi.org/10.1176/appi.ajp.2013.13030326

Avena, N. M., Bocarsly, M. E., Rada, P., Kim, A., \& Hoebel, B. G. (2008). After daily bingeing on a sucrose solution, food deprivation induces anxiety and accumbens dopamine/acetylcholine imbalance. Physiology \& Behavior, 94(3), 309-315.

https://doi.org/10.1016/j.physbeh.2008.01.008

Avena, N. M., Long, K. A., \& Hoebel, B. G. (2005). Sugar-dependent rats show enhanced responding for sugar after abstinence: Evidence of a sugar deprivation effect. Physiology \& Behavior, 84(3), 359-362. https://doi.org/10.1016/j.physbeh.2004.12.016

Avena, N. M., Rada, P., \& Hoebel, B. G. (2008). Evidence for sugar addiction: Behavioral and neurochemical effects of intermittent, excessive sugar intake. Neuroscience \& Biobehavioral Reviews, 32(1), 20-39. https://doi.org/10.1016/j.neubiorev.2007.04.019

Bardone-Cone, A. M., Wonderlich, S. A., Frost, R. O., Bulik, C. M., Mitchell, J. E., Uppala, S., \& Simonich, H. (2007). Perfectionism and eating disorders: Current status and future directions. Clinical Psychology Review, 27(3), 384-405. https://doi.org/10.1016/j.cpr.2006.12.005

Bastiani, A. M., Rao, R., Weltzin, T., \& Kaye, W. H. (1995). Perfectionism in anorexia nervosa. International Journal of Eating Disorders, 17(2), 147-152. https://doi.org/10.1002/1098108X(199503)17:2<147::AID-EAT2260170207>3.0.CO;2-X

Behrendt, S., Wittchen, H.-U., Höfler, M., Lieb, R., Low, N. C. P., Rehm, J., \& Beesdo, K. (2008). Risk and speed of transitions to first alcohol dependence symptoms in adolescents: a 10-year longitudinal community study in Germany. Addiction, 103(10), 1638-1647. https://doi.org/10.1111/j.1360-0443.2008.02324.x

Benzinger, H. (2013). Zum Verständnis von Abhängigkeiten aus psychodramatischer Sicht. Zeitschrift für Psychodrama und Soziometrie, 11(S1), 5-22. https://doi.org/10.1007/s11620-012-0159-4 
Berkman, N. D., Lohr, K. N., \& Bulik, C. M. (2007). Outcomes of eating disorders: A systematic review of the literature. International Journal of Eating Disorders, 40(4), 293-309. https://doi.org/10.1002/eat.20369

Berrington de Gonzalez, A., Hartge, P., Cerhan, J. R., Flint, A. J., Hannan, L., MacInnis, R. J., ... Thun, M. J. (2010). Body-Mass Index and Mortality among 1.46 Million White Adults. New England Journal of Medicine, 363(23), 2211-2219. https://doi.org/10.1056/NEJMoa1000367

Blaszczynski, A. (2015). Commentary on: Are we overpathologizing everyday life? A tenable blueprint for behavioral addiction research. Journal of Behavioral Addictions, 4(3), 142-144. https://doi.org/10.1556/2006.4.2015.016

Blundell, J. E., \& Finlayson, G. (2011). FOOD ADDICTION NOT HELPFUL: THE HEDONIC COMPONENT IMPLICIT WANTING - IS IMPORTANT: Commentaries. Addiction, 106(7), 1216-1218. https://doi.org/10.1111/j.1360-0443.2011.03413.x

Brownell, K. D., \& Gold, M. S. (2012a). Food and Addiction. In K. D. Brownell \& M. S. Gold (Eds.), Food and Addiction (pp. 439-446). Oxford University Press. Retrieved from http://www.oxfordclinicalpsych.com/view/10.1093/med:psych/9780199738168.001.0001/m ed-9780199738168-chapter-66

Brownell, K. D., \& Gold, M. S. (Eds.). (2012b). Food and addiction: a comprehensive handbook (1. ed). Oxford: Oxford Univ. Press.

Brunault, P., Ducluzeau, P.-H., Courtois, R., Bourbao-Tournois, C., Delbachian, I., Réveillère, C., \& Ballon, N. (2018). Food Addiction is Associated with Higher Neuroticism, Lower Conscientiousness, Higher Impulsivity, but Lower Extraversion in Obese Patient Candidates for Bariatric Surgery. Substance Use \& Misuse, 1-5. https://doi.org/10.1080/10826084.2018.1433212

Burrows, T., Kay-Lambkin, F., Pursey, K., Skinner, J., \& Dayas, C. (2018). Food addiction and associations with mental health symptoms: a systematic review with meta-analysis. Journal of Human Nutrition and Dietetics. https://doi.org/10.1111/jhn.12532 
Busch-Heizmann, A., \& Holst, E. (2017). Do Women in Highly Qualified Positions Face Higher Work-toFamily Conflicts in Germany than Men? SSRN Electronic Journal. https://doi.org/10.2139/ssrn.2957497

Buu, A., Wang, W., Schroder, S. A., Kalaida, N. L., Puttler, L. I., \& Zucker, R. A. (2012). Developmental emergence of alcohol use disorder symptoms and their potential as early indicators for progression to alcohol dependence in a high risk sample: A longitudinal study from childhood to early adulthood. Journal of Abnormal Psychology, 121(4), 897-908. https://doi.org/10.1037/a0024926

Calero-Elvira, A., Krug, I., Davis, K., López, C., Fernández-Aranda, F., \& Treasure, J. (2009). Metaanalysis on drugs in people with eating disorders. European Eating Disorders Review, 17(4), 243-259. https://doi.org/10.1002/erv.936

Christakis, N. A., \& Fowler, J. H. (2007). The Spread of Obesity in a Large Social Network over 32 Years. New England Journal of Medicine, 357(4), 370-379. https://doi.org/10.1056/NEJMsa066082

Colles, S. L., Dixon, J. B., \& O’Brien, P. E. (2008). Loss of Control Is Central to Psychological Disturbance Associated With Binge Eating Disorder. Obesity, 16(3), 608-614. https://doi.org/10.1038/oby.2007.99

Curtis, C., \& Davis, C. (2014). A Qualitative Study of Binge Eating and Obesity From an Addiction Perspective. Eating Disorders, 22(1), 19-32. https://doi.org/10.1080/10640266.2014.857515

DAG e.V. (2014, April). Interdisziplinäre Leitlinie der Qualität S3 zur „Prävention und Therapie der Adipositas". (Deutsche Adipositas-Gesellschaft (DAG) e.V., Deutsche Gesellschaft für Ernährung (DGE) e.V., Deutsche Gesellschaft für Ernährungsmedizin(DGEM) e.V., \& Deutsche Diabetes Gesellschaft (DDG), Eds.). Retrieved from http://www.adipositasgesellschaft.de/fileadmin/PDF/Leitlinien/S3_Adipositas_Praevention_Therapie_2014.pdf Dalton, M., \& Finlayson, G. (2014). Psychobiological examination of liking and wanting for fat and sweet taste in trait binge eating females. Physiology \& Behavior, 136, 128-134. https://doi.org/10.1016/j.physbeh.2014.03.019 
Darby, A., Hay, P., Mond, J., Quirk, F., Buttner, P., \& Kennedy, L. (2009). The rising prevalence of comorbid obesity and eating disorder behaviors from 1995 to 2005. International Journal of Eating Disorders, 42(2), 104-108. https://doi.org/10.1002/eat.20601

Davis, C. (2016). A commentary on the associations among "food addiction", binge eating disorder, and obesity: Overlapping conditions with idiosyncratic clinical features. Appetite, 1-6. https://doi.org/10.1016/j.appet.2016.11.001

Davis, C., Curtis, C., Levitan, R. D., Carter, J. C., Kaplan, A. S., \& Kennedy, J. L. (2011). Evidence that "food addiction" is a valid phenotype of obesity. Appetite, 57(3), 711-717. https://doi.org/10.1016/j.appet.2011.08.017

Davis, C., \& Loxton, N. J. (2013). Addictive behaviors and addiction-prone personality traits: Associations with a dopamine multilocus genetic profile. Addictive Behaviors, 38(7), 23062312. https://doi.org/10.1016/j.addbeh.2013.02.012

de Vries, S.-K., \& Meule, A. (2016). Food Addiction and Bulimia Nervosa: New Data Based on the Yale Food Addiction Scale 2.0: Food Addiction and Bulimia. European Eating Disorders Review, 24(6), 518-522. https://doi.org/10.1002/erv.2470

Deutsche Gesellschaft für Psychosomatische Medizin und Psychotherapie (DGPM). (2010). Diagnostik und Therapie der Essstörungen Gemeinsame S3-Leitlinie der Deutschen Gesellschaft für Psychosomatische Medizin und Psychotherapie (DGPM), des Deutschen Kollegium für Psychosomatische Medizin (DKPM), der Deutschen Ärztlichen Gesellschaft für Verhaltenstherapie (DÄVT), der Deutschen Gesellschaft für Kinder- und Jugendpsychiatrie und Psychotherapie (DGKJP), der Deutschen Gesellschaft für Psychiatrie, Psychotherapie und Nervenheilkunde (DGPPN) der Deutschen Gesellschaft für Psychologie (DGPs) und der Deutschen Gesellschaft für Verhaltensmedizin und Verhaltensmodifikation (DGVM) (S3 No. AWMF-Register Nr. 051/026) (p. 363). Retrieved from https://www.dgppn.de/_Resources/Persistent/f56be8ecd7f8f4ced46f9573b3451e0f78df1d6 7/S3-LL-Essstoerungen-Langfassung.pdf 
Dunn, J. G. H., Gotwals, J. K., \& Dunn, J. C. (2005). An examination of the domain specificity of perfectionism among intercollegiate student-athletes. Personality and Individual Differences, 38(6), 1439-1448. https://doi.org/10.1016/j.paid.2004.09.009

Ellert, U., \& Kurth, B. M. (2013). Gesundheitsbezogene Lebensqualität bei Erwachsenen in Deutschland: Ergebnisse der Studie zur Gesundheit Erwachsener in Deutschland (DEGS1). Bundesgesundheitsblatt - Gesundheitsforschung - Gesundheitsschutz, 56(5-6), 643-649. https://doi.org/10.1007/s00103-013-1700-y

Ellrott, T., \& Pudel, V. (1998). Adipositastherapie: aktuelle Perspektiven ; 7 Tabellen (2., aktualisierte Aufl). Stuttgart: Thieme.

Epstein, D. H., \& Shaham, Y. (2010). Cheesecake-eating rats and the question of food addiction. Nature Neuroscience, 13(5), 529-531. https://doi.org/10.1038/nn0510-529

Finlayson, G. (2017). Food addiction and obesity: unnecessary medicalization of hedonic overeating. Nature Reviews Endocrinology, 13(8), 493-498. https://doi.org/10.1038/nrendo.2017.61

Finlayson, G., \& Dalton, M. (2012). Hedonics of Food Consumption: Are Food "Liking" and "Wanting" Viable Targets for Appetite Control in the Obese? Current Obesity Reports, 1(1), 42-49. https://doi.org/10.1007/s13679-011-0007-2

Flint, A. J., Gearhardt, A. N., Corbin, W. R., Brownell, K. D., Field, A. E., \& Rimm, E. B. (2014). Foodaddiction scale measurement in 2 cohorts of middle-aged and older women. The American Journal of Clinical Nutrition, 99(3), 578-586. https://doi.org/10.3945/ajcn.113.068965

Foskett, R. L., \& Longstaff, F. (2017). The mental health of elite athletes in the United Kingdom. Journal of Science and Medicine in Sport. https://doi.org/10.1016/j.jsams.2017.11.016

Fraser, S. (2013). Junk: Overeating and obesity and the neuroscience of addiction. Addiction Research \& Theory, 21(6), 496-506. https://doi.org/10.3109/16066359.2012.749868

Gearhardt, A. N., Boswell, R. G., \& White, M. A. (2014). The association of "food addiction" with disordered eating and body mass index. Eating Behaviors, 15(3), 427-433. https://doi.org/10.1016/j.eatbeh.2014.05.001 
Gearhardt, A. N., \& Corbin, W. R. (2012). Food Addiction and Diagnostic Criteria for Dependence. In K. D. Brownell \& M. S. Gold (Eds.), Food and Addiction (pp. 167-171). Oxford University Press. Retrieved from http://www.oxfordclinicalpsych.com/view/10.1093/med:psych/9780199738168.001.0001/m ed-9780199738168-chapter-25

Gearhardt, A. N., Corbin, W. R., \& Brownell, K. D. (2009a). Food Addiction: An Examination of the Diagnostic Criteria for Dependence. Journal of Addiction Medicine, 3(1), 1-7. https://doi.org/10.1097/ADM.0b013e318193c993

Gearhardt, A. N., Corbin, W. R., \& Brownell, K. D. (2009b). Preliminary validation of the Yale Food Addiction Scale. Appetite, 52(2), 430-436. https://doi.org/10.1016/j.appet.2008.12.003

Gearhardt, A. N., Davis, C., Kuschner, R., \& Brownell, K. D. (2011). The addiction potential of hyperpalatable foods. Current Drug Abuse Reviews, 4(3), 140-145.

Gearhardt, A. N., White, M. A., \& Potenza, M. N. (2011). Binge eating disorder and food addiction. Current Drug Abuse Reviews, 4(3), 201-207.

Ghaderi, A., \& Scott, B. (2000). The Big Five and eating disorders: a prospective study in the general population. European Journal of Personality, 14(4), 311-323. https://doi.org/10.1002/10990984(200007/08)14:4<311::AID-PER378>3.0.CO;2-8

Gold, M. S., Frost-Pineda, K., \& Jacobs, W. S. (2003). Overeating, Binge Eating, and Eating Disorders as Addictions. Psychiatric Annals, 33(2), 117-122. https://doi.org/10.3928/0048-571320030201-08

Gorelick, D. A. (2015). Treatment of Cocaine Addiction. In N. el-Guebaly, G. Carrà, \& M. Galanter (Eds.), Textbook of Addiction Treatment: International Perspectives (pp. 381-404). Milano: Springer Milan. Retrieved from http://link.springer.com/10.1007/978-88-470-5322-9_15

Granero, R., Hilker, I., Agüera, Z., Jiménez-Murcia, S., Sauchelli, S., Islam, M. A., ... Fernández-Aranda, F. (2014). Food Addiction in a Spanish Sample of Eating Disorders: DSM-5 Diagnostic Subtype Differentiation and Validation Data: Food Addiction and ED Subtypes. European Eating Disorders Review, 22(6), 389-396. https://doi.org/10.1002/erv.2311 
Greenfield, S. F., \& Crisafulli, M. A. (2012). Co-Occurring Addiction and Psychiatric Disorders. In K. D. Brownell \& M. S. Gold (Eds.), Food and Addiction (pp. 47-52). Oxford University Press. Retrieved from http://www.oxfordclinicalpsych.com/view/10.1093/med:psych/9780199738168.001.0001/m ed-9780199738168-chapter-7

Guerrieri, R., Nederkoorn, C., \& Jansen, A. (2008). The effect of an impulsive personality on overeating and obesity: Current state of affairs. Psihologijske Teme, 17(2), 265-286.

Gulliver, A., Griffiths, K. M., Mackinnon, A., Batterham, P. J., \& Stanimirovic, R. (2015). The mental health of Australian elite athletes. Journal of Science and Medicine in Sport, 18(3), 255-261. https://doi.org/10.1016/j.jsams.2014.04.006

Hähni, von Känel, Nedeljkovic, Stanga, \& Ott. (2012). Charakteristika schwer essgestörter Patientinnen in einer universitären Einrichtung und therapeutische Richtlinien. PRAXIS, 101(17), 1089-1097. https://doi.org/10.1024/1661-8157/a001029

Hauck, C., \& Ellrott, T. (2017a). ,Food addiction' - addictive-like eating behavior. The current state of research with the Yale Food Addiction Scale. Ernahrungs Umschau, 102-110. https://doi.org/10.4455/eu.2017.023

Hauck, C., \& Ellrott, T. (2017b). Zusammenhänge zwischen Genuss und Übergewicht/Adipositas. Adipositas - Ursachen, Folgeerkrankungen, Therapie, Heft 4 2017(2017 (Vol. 11)), 192-197. Hauck, C., Schipfer, M., Ellrott, T., \& Cook, B. (n.d.). Food Addiction, exercise dependence and perfectionism in amateur athletes. Under Review.

Hauck, C., Weiß, A., \& Ellrott, T. (2016). Relationship between "food addiction", restrained eating behavior, mental health status and score of binge eating in a morbidly obese German sample. Adipositas, 10(4), 215-220.

Hauck, C., Weiß, A., Schulte, E. M., Meule, A., \& Ellrott, T. (2017). Prevalence of “Food Addiction" as Measured with the Yale Food Addiction Scale 2.0 in a Representative German Sample and Its Association with Sex, Age and Weight Categories. Obesity Facts, 10(1), 12-24. https://doi.org/10.1159/000456013 
Hebebrand, J., Albayrak, Ö., Adan, R., Antel, J., Dieguez, C., de Jong, J., ... Dickson, S. L. (2014). “Eating addiction", rather than "food addiction", better captures addictive-like eating behavior. Neuroscience \& Biobehavioral Reviews, 47, 295-306.

https://doi.org/10.1016/j.neubiorev.2014.08.016

Heriseanu, A. I., Hay, P., Corbit, L., \& Touyz, S. (2017). Grazing in adults with obesity and eating disorders: A systematic review of associated clinical features and meta-analysis of prevalence. Clinical Psychology Review, 58, 16-32. https://doi.org/10.1016/j.cpr.2017.09.004

Hilker, I., Sánchez, I., Steward, T., Jiménez-Murcia, S., Granero, R., Gearhardt, A. N., ... FernándezAranda, F. (2016). Food Addiction in Bulimia Nervosa: Clinical Correlates and Association with Response to a Brief Psychoeducational Intervention: Food Addiction and Treatment Response in BN. European Eating Disorders Review, 24(6), 482-488. https://doi.org/10.1002/erv.2473

Hoebel, B. G., Avena, N. M., Bocarsly, M. E., \& Rada, P. (2009). Natural Addiction: A Behavioral and Circuit Model Based on Sugar Addiction in Rats. Journal of Addiction Medicine, 3(1), 33-41. https://doi.org/10.1097/ADM.0b013e31819aa621

Hovrud, L., \& De Young, K. P. (2015). Unique contributions of individual eating disorder symptoms to eating disorder-related impairment. Eating Behaviors, 18, 103-106. https://doi.org/10.1016/j.eatbeh.2015.05.001 Imperatori, C., Innamorati, M., Contardi, A., Continisio, M., Tamburello, S., Lamis, D. A., ... Fabbricatore, M. (2014). The association among food addiction, binge eating severity and psychopathology in obese and overweight patients attending low-energy-diet therapy. Comprehensive Psychiatry, 55(6), 1358-1362. https://doi.org/10.1016/j.comppsych.2014.04.023 Ivezaj, V., Wiedemann, A. A., \& Grilo, C. M. (2017). Food addiction and bariatric surgery: a systematic review of the literature: Food addiction and bariatric surgery. Obesity Reviews, 18(12), 13861397. https://doi.org/10.1111/obr.12600 
Jacobi, F., Höfler, M., Strehle, J., Mack, S., Gerschler, A., Scholl, L., ... Wittchen, H.-U. (2014).

Psychische Störungen in der Allgemeinbevölkerung: Studie zur Gesundheit Erwachsener in Deutschland und ihr Zusatzmodul Psychische Gesundheit (DEGS1-MH). Der Nervenarzt, 85(1), 77-87. https://doi.org/10.1007/s00115-013-3961-y

Kearney, J. (2010). Food consumption trends and drivers. Philosophical Transactions of the Royal Society B: Biological Sciences, 365(1554), 2793-2807. https://doi.org/10.1098/rstb.2010.0149

Kirk, S. F. L., Price, S. L., Penney, T. L., Rehman, L., Lyons, R. F., Piccinini-Vallis, H., ... Aston, M. (2014). Blame, Shame, and Lack of Support: A Multilevel Study on Obesity Management. Qualitative Health Research, 24(6), 790-800. https://doi.org/10.1177/1049732314529667

Kolotkin, R. L., Meter, K., \& Williams, G. R. (2001). Quality of life and obesity. Obesity Reviews: An Official Journal of the International Association for the Study of Obesity, 2(4), 219-229.

Koob, G. F. (2012). Animal Models of Drug Addiction. In K. D. Brownell \& M. S. Gold (Eds.), Food and Addiction (pp. 3-13). Oxford University Press. Retrieved from http://www.oxfordclinicalpsych.com/view/10.1093/med:psych/9780199738168.001.0001/m ed-9780199738168-chapter-1

Koob, G. F., \& Le Moal, M. (1997). Drug abuse: hedonic homeostatic dysregulation. Science (New York, N.Y.), 278(5335), 52-58.

Kromann, C. B., \& Nielsen, C. T. (2012). A case of cola dependency in a woman with recurrent depression. BMC Research Notes, 5(1), 692. https://doi.org/10.1186/1756-0500-5-692

Leeman, R. F., Patock-Peckham, J. A., \& Potenza, M. N. (2012). Impaired control over alcohol use: An under-addressed risk factor for problem drinking in young adults? Experimental and Clinical Psychopharmacology, 20(2), 92-106. https://doi.org/10.1037/a0026463

Lent, M. R., Eichen, D. M., Goldbacher, E., Wadden, T. A., \& Foster, G. D. (2014). Relationship of food addiction to weight loss and attrition during obesity treatment: Food Addiction and Weight Loss. Obesity, 22(1), 52-55. https://doi.org/10.1002/oby.20512 
Long, C. G., Blundell, J. E., \& Finlayson, G. (2015). A Systematic Review of the Application And Correlates of YFAS-Diagnosed Food Addiction' in Humans: Are Eating-Related Addictions' a Cause for Concern or Empty Concepts? Obesity Facts, 8(6), 386-401. https://doi.org/10.1159/000442403

Meseri, R., Bilge, A., Kükücerdönmez, Ö., \& Altintoprak, E. (2016). Food Addiction and Obesity. Journal of Neurological Sciences, 33(2). Retrieved from http://jns.dergisi.org/abstract.php?lang=en\&id=960

Meule, A., de Zwaan, M., \& Müller, A. (2017). Attentional and motor impulsivity interactively predict "food addiction" in obese individuals. Comprehensive Psychiatry, 72, 83-87. https://doi.org/10.1016/j.comppsych.2016.10.001

Meule, A., \& Gearhardt, A. (2014a). Food Addiction in the Light of DSM-5. Nutrients, 6(12), 36533671. https://doi.org/10.3390/nu6093653

Meule, A., \& Gearhardt, A. N. (2014b). Five years of the Yale Food Addiction Scale: Taking stock and moving forward. Current Addiction Reports, 1(3), 193-205. https://doi.org/10.1007/s40429014-0021-z

Meule, A., Müller, A., Gearhardt, A. N., \& Blechert, J. (2016). German version of the Yale Food Addiction Scale 2.0: Prevalence and correlates of "food addiction" in students and obese individuals. Appetite, 1-8. https://doi.org/10.1016/j.appet.2016.10.003

Meule, A., von Rezori, V., \& Blechert, J. (2014). Food Addiction and Bulimia Nervosa: Food Addiction and Bulimia Nervosa. European Eating Disorders Review, 22(5), 331-337. https://doi.org/10.1002/erv.2306

Mischke, J., \& Wingerter. (2012). Frauen und Männer Auf dem Arbeitsmarkt Deutschland und Europa (p. 61). Wiesbaden. Retrieved from https://www.destatis.de/DE/Publikationen/Thematisch/Arbeitsmarkt/Erwerbstaetige/Broesc huereFrauenMaennerArbeitsmarkt0010018129004.pdf?_blob=publicationFile

Mitchison, D., Rieger, E., Harrison, C., Murray, S. B., Griffiths, S., \& Mond, J. (2018). Indicators of clinical significance among women in the community with binge-eating disorder symptoms: 
Delineating the roles of binge frequency, body mass index, and overvaluation. International Journal of Eating Disorders, 51(2), 165-169. https://doi.org/10.1002/eat.22812

Moeller, F. G., Barratt, E. S., Dougherty, D. M., Schmitz, J. M., \& Swann, A. C. (2001). Psychiatric Aspects of Impulsivity. American Journal of Psychiatry, 158(11), 1783-1793. https://doi.org/10.1176/appi.ajp.158.11.1783

Monteiro, C. A., Cannon, G., Moubarac, J.-C., Levy, R. B., Louzada, M. L. C., \& Jaime, P. C. (2018). The UN Decade of Nutrition, the NOVA food classification and the trouble with ultra-processing. Public Health Nutrition, 21(1), 5-17. https://doi.org/10.1017/S1368980017000234

Monteiro, C. A., Levy, R. B., Claro, R. M., Castro, I. R. R. de, \& Cannon, G. (2010). A new classification of foods based on the extent and purpose of their processing. Cadernos De Saude Publica, 26(11), 2039-2049.

NIDA. (2014). Drugs, Brains, and Behavior: The Science of Addiction. Retrieved from https://www.drugabuse.gov/publications/drugs-brains-behavior-science-addiction

Peitz, D., \& Warschburger, P. (2017). Mindful Eating - Das Potenzial von Achtsamkeit in der Adipositasbehandlung nutzen. Adipositas, 3/2017(11), 137-184.

Pepino, M. Y., Stein, R. I., Eagon, J. C., \& Klein, S. (2014). Bariatric surgery-induced weight loss causes remission of food addiction in extreme obesity: Food Addiction and Bariatric Surgery. Obesity, 22(8), 1792-1798. https://doi.org/10.1002/oby.20797

Pudel, V., \& Westenhöfer, J. (2003). Ernährungspsychologie: eine Einführung (3., unveränd. Aufl). Göttingen: Hogrefe, Verl. für Psychologie.

Puhl, R. M., \& Brownell, K. D. (2006). Confronting and Coping with Weight Stigma: An Investigation of Overweight and Obese Adults*. Obesity, 14(10), 1802-1815. https://doi.org/10.1038/oby.2006.208

Puhl, R. M., \& Heuer, C. A. (2010). Obesity Stigma: Important Considerations for Public Health. American Journal of Public Health, 100(6), 1019-1028. https://doi.org/10.2105/AJPH.2009.159491 
Pursey, K. M., Collins, C. E., Stanwell, P., \& Burrows, T. L. (2015). Foods and dietary profiles associated with "food addiction" in young adults. Addictive Behaviors Reports, 2, 41-48. https://doi.org/10.1016/j.abrep.2015.05.007

Pursey, K. M., Davis, C., \& Burrows, T. L. (2017). Nutritional Aspects of Food Addiction. Current Addiction Reports, 4(2), 142-150. https://doi.org/10.1007/s40429-017-0139-x

Pursey, K., Stanwell, P., Gearhardt, A., Collins, C., \& Burrows, T. (2014). The Prevalence of Food Addiction as Assessed by the Yale Food Addiction Scale: A Systematic Review. Nutrients, 6(10), 4552-4590. https://doi.org/10.3390/nu6104552

Rebscher H, Marschall J, Hildebrandt-Heene S et al. (2016) Schwerpunkt: Gender und Gesundheit Band 13. https://de.statista.com/themen/1318/psychische-erkrankungen/. Accessed 05 Sep 2016

Rehm, J., Room, R., Graham, K., Monteiro, M., Gmel, G., \& Sempos, C. T. (2003). The relationship of average volume of alcohol consumption and patterns of drinking to burden of disease: an overview. Addiction (Abingdon, England), 98(9), 1209-1228.

Reich, G. (2003). Familientherapie der Essstörungen. Göttingen: Hogrefe, Verl. für Psychologie.

Ricca, V., Castellini, G., Lo Sauro, C., Ravaldi, C., Lapi, F., Mannucci, E., ... Faravelli, C. (2009). Correlations between binge eating and emotional eating in a sample of overweight subjects. Appetite, 53(3), 418-421. https://doi.org/10.1016/j.appet.2009.07.008

Ruddock, H. K., Christiansen, P., Halford, J. C. G., \& Hardman, C. A. (2017). The development and validation of the Addiction-like Eating Behaviour Scale. International Journal of Obesity, 41(11), 1710-1717. https://doi.org/10.1038/ijo.2017.158

Saunders, R. (2004). “Grazing”: A High-Risk Behavior. Obesity Surgery, 14(1), 98-102. https://doi.org/10.1381/096089204772787374

Schag, K., Mack, I., Giel, K., Ölschläger, S., Skoda, E.-M., von Feilitzsch, M., ... Teufel, M. (2016). The Impact of Impulsivity on Weight Loss Four Years after Bariatric Surgery. Nutrients, 8(11), 721. https://doi.org/10.3390/nu8110721 


\section{Teil 3 Diskussion und Schlussfolgerung}

Schulte, E. M., Avena, N. M., \& Gearhardt, A. N. (2015). Which Foods May Be Addictive? The Roles of Processing, Fat Content, and Glycemic Load. PLOS ONE, 10(2), e0117959. https://doi.org/10.1371/journal.pone.0117959

Schulte, E. M., \& Gearhardt, A. N. (2017). Associations of Food Addiction in a Sample Recruited to Be Nationally Representative of the United States: Food Addiction in the United States. European Eating Disorders Review. https://doi.org/10.1002/erv.2575

Schweizerische Arbeitsgemeinschaft für Sportpsychologie. (2002). Gestörtes Essverhalten bei Sportlerinnen und Sportlern - Positionspapier No. 2 der Schweizerischen Arbeitsgemeinschaft für Sportpsychologie (No. 50-2002) (p. 1). Retrieved from https://sgsm.ch/fileadmin/user_upload/Zeitschrift/50-2002-2/09-2002-2.pdf

Sevinçer, G. M., Konuk, N., Bozkurt, S., \& Coşkun, H. (2016). Food addiction and the outcome of bariatric surgery at 1-year: Prospective observational study. Psychiatry Research, 244, 159164. https://doi.org/10.1016/j.psychres.2016.07.022

Stock, A.-K. (2017). Barking up the Wrong Tree: Why and How We May Need to Revise Alcohol Addiction Therapy. Frontiers in Psychology, 8. https://doi.org/10.3389/fpsyg.2017.00884

Stoeber, J. (2011). The dual nature of perfectionism in sports: relationships with emotion, motivation, and performance. International Review of Sport and Exercise Psychology, 4(2), 128-145. https://doi.org/10.1080/1750984X.2011.604789

Stoeber, J., \& Otto, K. (2006). Positive Conceptions of Perfectionism: Approaches, Evidence, Challenges. Personality and Social Psychology Review, 10(4), 295-319. https://doi.org/10.1207/s15327957pspr1004_2

Stoeber, J., \& Stoeber, F. S. (2009). Domains of perfectionism: Prevalence and relationships with perfectionism, gender, age, and satisfaction with life. Personality and Individual Differences, 46(4), 530-535. https://doi.org/10.1016/j.paid.2008.12.006

Stoeber, J., Uphill, M. A., \& Hotham, S. (2009). Predicting race performance in triathlon: the role of perfectionism, achievement goals, and personal goal setting. Journal of Sport \& Exercise Psychology, 31(2), 211-245. 


\section{Teil 3 Diskussion und Schlussfolgerung}

Substance Abuse and Mental Health Services Administration. (2013). Results from the 2012 National Survey on Drug Use and Health: Summary of National Findings. (NSDUH Series H-46, HHS Publication No. (SMA) 13-4795) (p. 178). Rockville, MD. Retrieved from https://www.samhsa.gov/data/sites/default/files/NSDUHresults2012/NSDUHresults2012.pdf

Sudi, K., Öttl, K., Payerl, D., Baumgartl, P., Tauschmann, K., \& Müller, W. (2004). Anorexia athletica. Nutrition, 20(7-8), 657-661. https://doi.org/10.1016/j.nut.2004.04.019

Sundgot-Borgen, J., \& Torstveit, M. K. (2004). Prevalence of Eating Disorders in Elite Athletes Is Higher Than in the General Population: Clinical Journal of Sport Medicine, 14(1), 25-32. https://doi.org/10.1097/00042752-200401000-00005

Sussman. (2017). Substance and behavioral addictions: concepts, causes, and cures.

Sussman, S., \& Sussman, A. N. (2011). Considering the Definition of Addiction. International Journal of Environmental Research and Public Health, 8(12), 4025-4038. https://doi.org/10.3390/ijerph8104025

Swarna Nantha, Y., Abd Patah, N. A., \& Ponnusamy Pillai, M. (2016). Preliminary validation of the Malay Yale Food Addiction Scale: Factor structure and item analysis in an obese population. Clinical Nutrition ESPEN, 16, 42-47. https://doi.org/10.1016/j.clnesp.2016.08.001

The Alliance for Eating Disorders Awareness. (n.d.). Eating Disorders Statistics. Retrieved from https://www.ndsu.edu/fileadmin/counseling/Eating_Disorder_Statistics.pdf

Timko, C. A., \& Perone, J. (2005). Rigid and flexible control of eating behavior in a college population. Eating Behaviors, 6(2), 119-125. https://doi.org/10.1016/j.eatbeh.2004.09.002

Treasure, J., Claudino, A. M., \& Zucker, N. (2010). Eating disorders. The Lancet, 375(9714), 583-593. https://doi.org/10.1016/\$0140-6736(09)61748-7

Vainik, U., \& Meule, A. (2017). Jangle fallacy epidemic in obesity research: a comment on Ruddock et al. (2017). International Journal of Obesity. https://doi.org/10.1038/ijo.2017.264

Vallis, M. (2016). Quality of life and psychological well-being in obesity management: improving the odds of success by managing distress. International Journal of Clinical Practice, 70(3), 196205. https://doi.org/10.1111/ijcp.12765 


\section{Teil 3 Diskussion und Schlussfolgerung}

VanderBroek-Stice, L., Stojek, M. K., Beach, S. R. H., vanDellen, M. R., \& MacKillop, J. (2017). Multidimensional assessment of impulsivity in relation to obesity and food addiction. Appetite, 112, 59-68. https://doi.org/10.1016/j.appet.2017.01.009

Veenstra, E. M., \& de Jong, P. J. (2010). Restrained eaters show enhanced automatic approach tendencies towards food. Appetite, 55(1), 30-36. https://doi.org/10.1016/j.appet.2010.03.007

Volkow, N. D., \& Wise, R. A. (2005). How can drug addiction help us understand obesity? Nature Neuroscience, 8(5), 555-560. https://doi.org/10.1038/nn1452

Volkow, N. D. (2010). Comorbidity: Addiction and Other Mental Disorders. Retrieved August 12, 2016, from https://d14rmgtrwzf5a.cloudfront.net/sites/default/files/rrcomorbidity.pdf

VuMA (Arbeitsgemeinschaft Verbrauchs- und Medienanalyse). (2017). McDonald's-Kunden in Deutschland nach Alter im Vergleich mit der Bevölkerung im Jahr 2017. Statista - Das Statistik-Portal. Retrieved from https://de.statista.com/statistik/daten/studie/302241/umfrage/umfrage-in-deutschlandzum-alter-der-kunden-von-mcdonald-s/

Wagner, H. S., Ahlstrom, B., Redden, J. P., Vickers, Z., \& Mann, T. (2014). The myth of comfort food. Health Psychology, 33(12), 1552-1557. https://doi.org/10.1037/hea0000068

Warburton, D. E. R. (2006). Health benefits of physical activity: the evidence. Canadian Medical Association Journal, 174(6), 801-809. https://doi.org/10.1503/cmaj.051351

Westenhoefer, J., Stunkard, A. J., \& Pudel, V. (1999). Validation of the flexible and rigid control dimensions of dietary restraint. The International Journal of Eating Disorders, 26(1), 53-64.

Westwater, M. L., Fletcher, P. C., \& Ziauddeen, H. (2016). Sugar addiction: the state of the science. European Journal of Nutrition, 55(S2), 55-69. https://doi.org/10.1007/s00394-016-1229-6

White, M., Hill, S., McGovern, P., Mills, C., \& Smeaton, D. (2003). “High-performance” Management Practices, Working Hours and Work-Life Balance. British Journal of Industrial Relations, 41(2), 175-195. https://doi.org/10.1111/1467-8543.00268 


\section{Teil 3 Diskussion und Schlussfolgerung}

Wise, R. A., \& Koob, G. F. (2014). The Development and Maintenance of Drug Addiction. Neuropsychopharmacology, 39(2), 254-262. https://doi.org/10.1038/npp.2013.261

World Health Organization (Ed.). (2000). Obesity: preventing and managing the global epidemic; report of a WHO consultation. Geneva: World Health Organization.

World Health Organization. (2014). Global alcohol report_Germany. Retrieved from http://www.who.int/substance_abuse/publications/global_alcohol_report/profiles/deu.pdf

Yanos, B. R., Saules, K. K., Schuh, L. M., \& Sogg, S. (2015). Predictors of Lowest Weight and Long-Term Weight Regain Among Roux-en-Y Gastric Bypass Patients. Obesity Surgery, 25(8), 1364-1370. https://doi.org/10.1007/s11695-014-1536-z

Zeeck, A., Leonhart, R., Mosebach, N., Schlegel, S., Linster, H. W., \& Hartmann, A. (2013). Psychopathologische Aspekte von Sport: Eine deutsche Adaptation der „Exercise Dependence Scale“ (EDS-R). Zeitschrift für Sportpsychologie, 20(3), 94-106. https://doi.org/10.1026/1612-5010/a000099

Zeeck, A., \& Schlegel, S. (2012). Sportliche Aktivität und Essstörungen. In R. Fuchs \& W. Schlicht, Seelische Gesundheit und sportliche Aktivität (pp. 229-250). S.I.: Hogrefe Verlag.

Ziauddeen, H., Farooqi, I. S., \& Fletcher, P. C. (2012). Obesity and the brain: how convincing is the addiction model? Nature Reviews Neuroscience, 13, 279-286.

https://doi.org/10.1038/nrn3212 


\section{Anhangsverzeichnis}

Publizierter Originalartikel:

Prevalence of Food Addiction as Measured with the Yale Food Addiction Scale 2.0 in a Representative German Sample and Its Association with Sex, Age and Weight Categories

Publizierter Originalartikel:

„Food Addiction“, gezügeltes Essverhalten, mentaler Gesundheitsstatus und Heißhungersymptome bei morbider Adipositas

Publizierter Originalartikel:

,Food Addiction: - Suchtartiges Essverhalten - Stand der Forschung mit der Yale Food Addiction Scale

Publizierter Originalartikel:

Zusammenhänge zwischen Genuss und Übergewicht/ Adipositas

Eingesetzte Fragebögen

Aufbau der Studien

Lebenslauf

VII

Eidessstattliche Erklärung

VIII 


\title{
Prevalence of 'Food Addiction' as Measured with the Yale Food Addiction Scale 2.0 in a Representative German Sample and Its Association with Sex, Age and Weight Categories
}

\author{
Carolin Hauck $^{a} \quad$ Annegret Weiß ${ }^{a}$ Erica Marla Schulte ${ }^{b} \quad$ Adrian Meule $^{c}$ \\ Thomas Ellrott ${ }^{a}$ \\ anstitute for Nutrition and Psychology, University Medicine Göttingen, Göttingen, Germany; \\ ${ }^{b}$ Department of Psychology, University of Michigan, Ann Arbor, MI, USA; ${ }^{c}$ Department of \\ Psychology, Center for Cognitive Neuroscience, University of Salzburg, Salzburg, Austria
}

\section{Key Words}

'Food Addiction' · Yale Food Addiction Scale 2.0 · Underweight · Obesity · Body mass index

\begin{abstract}
Background/Aims: To assess the prevalence and correlates of addictive-like eating behavior in Germany. Methods: The German version of the Yale Food Addiction Scale (YFAS) 2.0 was used to investigate, for the first time, the prevalence of 'food addiction' in a representative sample aged 18-65 years $(\mathrm{N}=1,034)$. Results: The prevalence of 'food addiction' measured by the YFAS 2.0 was $7.9 \%$. Individuals meeting criteria for 'food addiction' had higher BMI and were younger than individuals not meeting the threshold. Underweight (15.0\%) and obese (17.2\%) individuals exhibited the highest prevalence rate of 'food addiction'. Addictive-like eating was not associated with sex, education level, or place of residence. Conclusion: YFAS 2.0 'food addiction' was met by nearly $8 \%$ of the population. There is a non-linear relationship between addictive-like eating and BMI, with the highest prevalence among underweight and obese persons. These findings suggest that 'food addiction' may be a contributor to overeating but may also reflect a distinct phenotype of problematic eating behavior not synonymous with obesity. Further, the elevated prevalence of YFAS 2.0 'food addiction' among underweight individuals may reflect an overlap with eating disorders and warrants attention in future research.


Hauck et al.: Prevalence of 'Food Addiction' as Measured with the Yale Food Addiction Scale 2.0 in a Representative German Sample and Its Association with Sex, Age and Weight Categories

\section{Introduction}

Obesity is a pressing public health problem in Germany, with approximately $23-24 \%$ of the population currently categorized as obese [1]. Obesity has multifactorial origins, including sedentary lifestyle and the overconsumption of calorie-dense foods [2]. Though there is evidence for factors contributing to the development of obesity (e.g. calorie imbalance, lack of physical exercise, genetic conditions) [3-5], current non-surgical intervention approaches for weight loss have limited long-term success [6]. In an attempt to further elucidate contributors to obesity and eating-related problems, recent studies have examined whether some individuals may experience 'food addiction' [7]. The 'food addiction' construct posits that highly processed foods, with added fats and/or refined carbohydrates, (e.g., pizza, chocolate, sugar-sweetened beverages) may be capable of triggering an addictive-like response in some individuals [8, 9]. 'Food addiction' reflects a substance-based perspective, whereby the potentially addictive nature of highly processed foods interacts with an individual's susceptibility to addiction to result in a phenotype consistent with addictive-like eating [8]. In this article, the terms 'food addiction' and 'addictive-like eating behavior' both reflect this substancebased perspective.

'Food addiction' is controversial [10] given that few studies have yet examined which foods may be addictive $[9,11]$, though the topic is of growing scientific and public interest [12-15]. In support of the 'food addiction' theory, animal models provide evidence that highly processed foods (e.g., cheesecake, Oreo cookies) or ingredients added to highly processed foods (e.g., sugar) may be capable of triggering biological (e.g., downregulation of dopamine) and behavioral (e.g., bingeing, use despite negative consequences) processes in a manner similar to drug abuse [16-21].

In humans, the Yale Food Addiction Scale (YFAS) [22] is the only validated instrument to operationalize addictive-like eating behavior [23-25] based on Diagnostic and Statistical Manual of Mental Disorders (DSM) criteria for substance use disorders. Recently, a revised version based on the DSM, version 5 (DSM-5), substance-related and addictive disorders (SRAD) criteria was developed and validated (YFAS 2.0) [25]. Generally, approximately $5-10 \%$ of individuals in community-based samples exhibit indicators of YFAS 'food addiction' $[24,25]$, though prevalence is higher among individuals with obesity [26] and binge eating disorder $[27,28]$. The YFAS has been translated into multiple languages to assess the prevalence of addictive-like eating behavior worldwide [23, 26, 29].

Previous studies utilizing the YFAS have observed that in some individuals addictive-like processes may contribute to problematic eating behavior via key mechanisms underlying addictive disorders, e.g., greater impulsivity, emotion dysregulation, and elevated craving [30-33]. For example, individuals reporting behavioral indicators of YFAS 'food addiction' exhibit similar patterns of reward-related neural responses when anticipating and receiving a highly processed food (e.g. ice cream) as individuals with substance use disorders with respect to the relevant drug [34]. In summary, individuals who endorse indicators of 'food addiction' on the YFAS may share biological and behavioral characteristics with persons with substance use disorders, and highly processed high-calorie foods appear to be particularly associated with addictive-like eating behavior. Elevated YFAS scores have also been associated with indicators of impulsivity (e.g., negative urgency) $[35,36]$ and greater endorsement of emotion regulation difficulties on self-report measures [27, 28, 36].

Recently, the YFAS was translated into the German language [37] to evaluate the prevalence and correlates of 'food addiction' in a German sample. Similar to previous studies utilizing the original YFAS [24], this preliminary work observed that $9.7 \%$ of individuals met the threshold for 'food addiction' and had an elevated BMI, relative to those who did not meet for a 'food addiction' [37]. However, this previous study had several limitations that reduce 
Hauck et al.: Prevalence of 'Food Addiction' as Measured with the Yale Food Addiction Scale 2.0 in a Representative German Sample and Its Association with Sex, Age and Weight Categories

the generalizability of the findings, such as limited generalizability to the German population, as participants were university students, and an overrepresentation of females (89\%). Thus, investigation of the prevalence and associations of addictive-like eating behavior in a more representative German sample is warranted.

The current study aims to address limitations and build upon previous work [37] in two significant ways. First, the present sample uses standard practices for representative research to yield a more demographically representative sample of the German population (e.g., age, gender, education level). Second, a German translation of the most current version of the YFAS 2.0, adapted from the DSM-5 criteria for SRAD, is used to assess addictive-like eating behaviors. The present study aims at examining the prevalence of 'food addiction' in a large, more representative German sample and investigate the correlates of 'food addiction' with weight class and demographic variables (e.g., age, sex). This study is an essential further step in elucidating whether 'food addiction' may have relevance to obesity and eating-related problems in the German population as well as in identifying individual characteristics (e.g., sex) that may be particularly associated with 'food addiction.'

\section{Hypotheses}

Based on previous research, it is hypothesized that the prevalence rate of 'food addiction' in the German population is between 5 and 10\% [23]. Among persons with obesity, the occurrence of 'food addiction' will be higher compared to those with normal weight [23]. The authors furthermore hypothesize that the occurrence of 'food addiction' is higher among underweight individuals, compared to those with normal weight, as one previous study observed that 'food addiction' prevalence is elevated in eating disorders associated with underweight (e.g., anorexia nervosa) [29].Consistent with previous literature, we expect that 'food addiction' will be more prevalent among women [22, 24, 25] and negatively related to age [38].

\section{Material and Methods}

\section{Ethics Statement}

The study was approved by the ethical guidelines of 'Lightspeed-Research' by Taylor Nelson Sofres (TNS) Infratest. The ethical guidelines ICC/ESOMAR were adhered to. Certifications are ISO 20252, ISO 9001 and ISO 27001. Written informed consent was obtained from all participants.

\section{Study Sample}

Participants were recruited via the German part of the global panel 'Lightspeed-Research' by Taylor Nelson Sofres (TNS) Infratest, which served as recruiting associate to ensure the representative character of the study. Participants were invited via a personalized link for a self-administered online survey to complete the questionnaire and fill in demographic information (sex, age, height, weight). Individuals $(n=14,086)$ were electronically invited to participate in the study, and a subset $(n=1,662)$ clicked on the link. Participants were excluded for having incomplete data $(n=59)$, the allocated quota for representativeness was achieved ( $n=507)$, not meeting age or education criteria $(n=45)$, or for providing poor quality data $(n=17)$. Thus, 1,034 German participants were included into the study. Informed consent was given by the participants in the course of a panel registration, and participants received 20 Eurocents for completing this study, similar to compensation rates for other TNS Infratest studies with this length.

Participants self-reported sex, age, educational level, city size, region, weight, and height (table 1). A quota sample was conducted for sex (male, female), age group (18-29, 30-39, 40-49, 50-65 years), educational level (low/medium, high/higher), city size (up to 20,000, 20,000-100,000, more than 100,000) and region (16 German states). Participants were aged $18-65$ years (mean $=41.3$ years, $S D=11.9$ years, range $=$ $18-63$ years), $51 \%$ were male, and mean BMI was $26.7 \mathrm{~kg} / \mathrm{m}^{2}\left(\mathrm{SD}=5.8 \mathrm{~kg} / \mathrm{m}^{2}\right.$, range $=15.6-59.5 \mathrm{~kg} / \mathrm{m}^{2}$ ). BMI was used to categorize study participants into different weight classes (defined by WHO with measurement unit $\left(\mathrm{kg} / \mathrm{m}^{2}\right)$ [39]). BMI categories are as follows: underweight $<18.5 \mathrm{~kg} / \mathrm{m}^{2}$, normal weight 
Hauck et al.: Prevalence of 'Food Addiction' as Measured with the Yale Food Addiction Scale 2.0 in a Representative German Sample and Its Association with Sex, Age and Weight Categories

Table 1. Demographic characteristics of the sample compared to the German population (18-65 years)*

\begin{tabular}{|c|c|c|}
\hline Demographic characteristics & $\begin{array}{l}\text { Study sample } \\
(\mathrm{n}=1,036)\end{array}$ & $\begin{array}{l}\text { German population } \\
\text { (58.8 million) }\end{array}$ \\
\hline Age, years & 41.3 & 42.7 \\
\hline \multicolumn{3}{|l|}{ Sex, \% } \\
\hline Male & 51.0 & 50.4 \\
\hline Female & 49.0 & 49.6 \\
\hline $\mathrm{BMI}, \mathrm{kg} / \mathrm{m}^{2}$ & 26.7 & $25.9^{\#}$ \\
\hline \multicolumn{3}{|l|}{ Federal state, $\%$} \\
\hline Schleswig-Holstein & 3.0 & 3.3 \\
\hline Hamburg & 2.0 & 2.2 \\
\hline Lower Saxony & 10.0 & 9.6 \\
\hline Bremen & 1.0 & 0.8 \\
\hline North Rhine-Westphalia & 22.0 & 21.8 \\
\hline Hesse & 8.0 & 7.5 \\
\hline Rhineland-Palatinate & 5.0 & 5.0 \\
\hline Baden-Württemberg & 13.0 & 13.0 \\
\hline Bavaria & 15.0 & 15.6 \\
\hline Saarland & 1.0 & 1.2 \\
\hline Berlin & 4.0 & 4.5 \\
\hline Brandenburg & 2.0 & 3.0 \\
\hline Mecklenburg-West Pomerania & 3.0 & 2.0 \\
\hline Saxony & 5.0 & 5.0 \\
\hline Saxony-Anhalt & 2.0 & 2.8 \\
\hline Thuringia & 3.0 & 2.7 \\
\hline \multicolumn{3}{|l|}{ Size of municipality, \% } \\
\hline$<20,000$ inhabitants & 39.0 & 40.4 \\
\hline $20,000-100,000$ inhabitants & 28.0 & 27.4 \\
\hline$>100,000$ inhabitants & 33.0 & 32.3 \\
\hline \multicolumn{3}{|l|}{ Education level, \% } \\
\hline Intermediate/low & 66.0 & 65.4 \\
\hline High (university entrance diploma / university degree) & 33.0 & 34.6 \\
\hline \multicolumn{3}{|l|}{ Amount of people within the household, \% } \\
\hline 1 & 24.0 & 20.9 \\
\hline 2 & 34.0 & 33.1 \\
\hline 3 & 22.0 & 21.2 \\
\hline$\geq 4$ & 20.0 & 24.8 \\
\hline \multicolumn{3}{|l|}{ Age groups, \% } \\
\hline $18-29$ years & 23.0 & $22.0^{* *}$ \\
\hline $30-39$ years & 19.0 & $19.0^{* *}$ \\
\hline $40-49$ years & 27.0 & $26.0^{* *}$ \\
\hline $50-65$ years & 31.0 & $33.0^{* *}$ \\
\hline
\end{tabular}

* Data provided by b4p [59].

\# Data provided by microcensus 2013 (age group $18-\geq 75$ years) [60].

** Data provided by world population database by TNS Infratest (internal data). 
Hauck et al.: Prevalence of 'Food Addiction' as Measured with the Yale Food Addiction

Scale 2.0 in a Representative German Sample and Its Association with Sex, Age and

Weight Categories

Table 2. Symptoms, illustrative items* and item count* (number of questions adding up for each of the symptoms) of the YFAS 2.0

\begin{tabular}{|c|c|c|}
\hline Symptoms & Original example items * & Count \\
\hline Loss of control & 'When I started to eat certain foods, I ate much more than planned.' & 3 \\
\hline Unsuccessful cut-down & $\begin{array}{l}\text { 'I worried a lot about cutting down on certain types of food, but I ate } \\
\text { them anyways.' }\end{array}$ & 4 \\
\hline Time spent & 'I spent a lot of time feeling sluggish or tired from overeating.' & 3 \\
\hline Activities given up & $\begin{array}{l}\text { 'I avoided work, school or social activities because I was afraid I } \\
\text { would overeat there.' }\end{array}$ & 4 \\
\hline Aversive consequences & $\begin{array}{l}\text { 'I kept eating in the same way even though my eating caused } \\
\text { emotional problems.' }\end{array}$ & 2 \\
\hline Tolerance & $\begin{array}{l}\text { 'Eating the same amount of food did not give me as much enjoyment } \\
\text { as it used to.' }\end{array}$ & 2 \\
\hline Withdrawal & $\begin{array}{l}\text { 'When I cut down on or stopped eating certain foods, I felt irritable, } \\
\text { nervous or sad.' }\end{array}$ & 5 \\
\hline Interpersonal problems & $\begin{array}{l}\text { 'I had problems with my family or friends because of how much I } \\
\text { overate.' }\end{array}$ & 3 \\
\hline Impaired daily functioning & $\begin{array}{l}\text { 'My overeating got in the way of me taking care of my family or doing } \\
\text { household chores.' }\end{array}$ & 2 \\
\hline Dangerous situations & $\begin{array}{l}\text { 'I was so distracted by eating that I could have been hurt (e.g., when } \\
\text { driving a car, crossing the street, operating machinery).' }\end{array}$ & 3 \\
\hline Craving & $\begin{array}{l}\text { 'I had such strong urges to eat certain foods that I couldn't think of } \\
\text { anything else.' }\end{array}$ & 2 \\
\hline $\begin{array}{l}\text { Clinically significant } \\
\text { impairment }\end{array}$ & 'My eating behavior caused me a lot of distress.' & 2 \\
\hline
\end{tabular}

*According to [25].

$18.5-24.9 \mathrm{~kg} / \mathrm{m}^{2}$, overweight $25-29.9 \mathrm{~kg} / \mathrm{m}^{2}$, obese $\geq 30 \mathrm{~kg} / \mathrm{m}^{2}$. Men and women did not differ in age $\left(\chi^{2}(42)=36.04 ; \mathrm{p}<0.73\right)$, but men had higher BMI $\left(\chi^{2}(714)=864.69 ; \mathrm{p}<0.001\right)$.

\section{'Food Addiction' Assessment}

The current version of the YFAS (YFAS 2.0) applies the eleven DSM-5 [40] criteria for SRAD (e.g., craving, continued use despite negative consequences) to the consumption of foods [40]. The YFAS 2.0 is a 35-item self-report questionnaire designed to operationalize indicators of addictive-like eating, based on the eleven DSM-5 criteria for SRAD (table 2 provides an exhaustive list of symptoms). The YFAS 2.0 can be scored on a continuous scale to measure the number of DSM-5 SRAD criteria an individual meets, ranging from 0-11. A second scoring method utilizes a threshold for a YFAS 2.0 'food addiction' 'diagnosis' which can be met by endorsing two or more DSM-5 SRAD criteria when the substance is certain foods, plus clinically significant distress or impairment. Given that the DSM-5 does not recognize 'food addiction' as a SRAD, the term 'diagnosis' in the current paper reflects meeting the described YFAS scoring criteria. Additionally, the term 'YFAS 2.0 food addiction' reflects meeting criteria for this 'diagnostic' threshold. The YFAS 2.0 has demonstrated internal reliability $(\alpha=0.90)$ and convergent validity with other measures of problematic eating $[22,24,25]$. In the current sample the German version of the YFAS 2.0 was used [37], and internal consistency was KuderRichardson's $\alpha=0.91$. 
Hauck et al.: Prevalence of 'Food Addiction' as Measured with the Yale Food Addiction Scale 2.0 in a Representative German Sample and Its Association with Sex, Age and Weight Categories

Table 3. Frequencies of endorsed YFAS 2.0 'food addiction' symptoms, by weight class

\begin{tabular}{|c|c|c|c|c|c|c|c|c|c|c|}
\hline \multirow[t]{2}{*}{ YFAS-'food addiction' criteria } & \multicolumn{2}{|c|}{ Underweight } & \multicolumn{2}{|c|}{ Normal } & \multicolumn{2}{|c|}{ Overweight } & \multicolumn{2}{|c|}{ Obese } & \multicolumn{2}{|l|}{ Total } \\
\hline & $\mathrm{n}^{*}$ & $\%^{\#}$ & $\mathrm{n}^{*}$ & $\%{ }^{\#}$ & $\mathrm{n}^{*}$ & $\%^{\#}$ & $\mathrm{n}^{*}$ & $\%{ }^{\#}$ & $\mathrm{n}^{*}$ & $\%^{\#}$ \\
\hline Loss of control & 5 & 25 & 74 & 16.9 & 58 & 16.1 & 62 & 28.8 & 199 & 19.2 \\
\hline Unsuccessful cut-down & 4 & 20 & 49 & 11.2 & 50 & 13.9 & 58 & 27.0 & 161 & 15.6 \\
\hline Time spent & 4 & 20 & 45 & 10.3 & 29 & 8.0 & 42 & 19.5 & 120 & 11.6 \\
\hline Activities given up & 6 & 30 & 77 & 17.6 & 53 & 14.7 & 59 & 18.9 & 195 & 18.9 \\
\hline Aversive consequences & 5 & 25 & 42 & 9.6 & 35 & 9.7 & 49 & 22.8 & 131 & 12.7 \\
\hline Tolerance & 2 & 10 & 26 & 5.9 & 20 & 5.5 & 29 & 13.5 & 77 & 7.4 \\
\hline Withdrawal & 3 & 15 & 78 & 17.8 & 53 & 14.7 & 57 & 26.5 & 191 & 18.5 \\
\hline Interpersonal problems & 6 & 30 & 74 & 16.9 & 53 & 14.7 & 56 & 26.0 & 189 & 18.3 \\
\hline Impaired daily functioning & 4 & 20 & 76 & 17.4 & 47 & 13.0 & 52 & 24.2 & 179 & 17.3 \\
\hline Dangerous situations & 4 & 20 & 73 & 16.7 & 53 & 14.7 & 59 & 27.4 & 189 & 18.3 \\
\hline Craving & 3 & 15 & 43 & 9.8 & 31 & 8.6 & 37 & 17.2 & 114 & 11.0 \\
\hline Clinically significant impairment & 3 & 15 & 27 & 6.2 & 18 & 5.0 & 40 & 18.6 & 88 & 8.5 \\
\hline People overall within the weight class & 20 & & 438 & & 361 & & 215 & & 1,034 & \\
\hline 'Food addiction' within the weight class & 3 & 15 & 24 & 5.5 & 18 & 5.0 & 37 & 17.2 & 82 & 7.9 \\
\hline
\end{tabular}

\section{Statistical Analyses}

To assess whether continuous data (BMI, age, number of symptoms) were normally distributed, Kolmogorov-Smirnov-tests were applied. Differences between individuals with and without YFAS 2.0 'food addiction' were examined with $\chi^{2}$-tests for categorical variables (sex, BMI categories). Spearman's correlation coefficients were used to examine associations between the number of YFAS 2.0 symptoms and continuous variables (age, BMI).

This analytic approach allowed us to evaluate i) the prevalence of YFAS 2.0 'food addiction' symptoms in the German population and ii) the correlation between sociodemographic and anthropometric variables with addictive-like eating behavior.

\section{Results}

Scores of BMI $(\mathrm{D}(1,034)=0.11, \mathrm{p}<0.001$, skewness $=1.52)$, age $(\mathrm{D}(1,034)=0.11, \mathrm{p}<$ 0.001 , skewness $=-0.34)$ and amount of symptoms $(\mathrm{D}(1,034)=0.33, \mathrm{p}<0.001$, skewness $=$ 1.78) differed significantly from normal. Data on educational level, city size, and region did not differ significantly between those who met for a YFAS 2.0 'diagnosis' of 'food addiction' and those who did not.

\section{Prevalence of 'Food Addiction'}

In the current sample, the mean number of YFAS 2.0 symptoms was 1.69 (SD 2.88, range $0-11$, Median 0), and prevalence of YFAS 2.0 'food addiction' was $7.9 \%(n=82)$. Comparisons were drawn between the two categories of 'food addiction' and no 'food addiction'.

\section{'Food Addiction' and Weight Category}

Table 3 shows the breakdown of individuals who met criteria for 'food addiction', as assessed by the YFAS 2.0, by weight class. When combining all three obese categories into one, a prevalence of $17.2 \%$ of YFAS 2.0 'food addiction' occurred among obese participants. Figure 1 shows the percentage of persons meeting YFAS 2.0 threshold for 'food addiction' according to weight category. A significant association was found between BMI and both YFAS 2.0 'food addiction' $\left(\chi^{2}(3)=34.61, p<0.001\right)$ and the number of endorsed symptoms 
Hauck et al.: Prevalence of 'Food Addiction' as Measured with the Yale Food Addiction

Scale 2.0 in a Representative German Sample and Its Association with Sex, Age and

Weight Categories

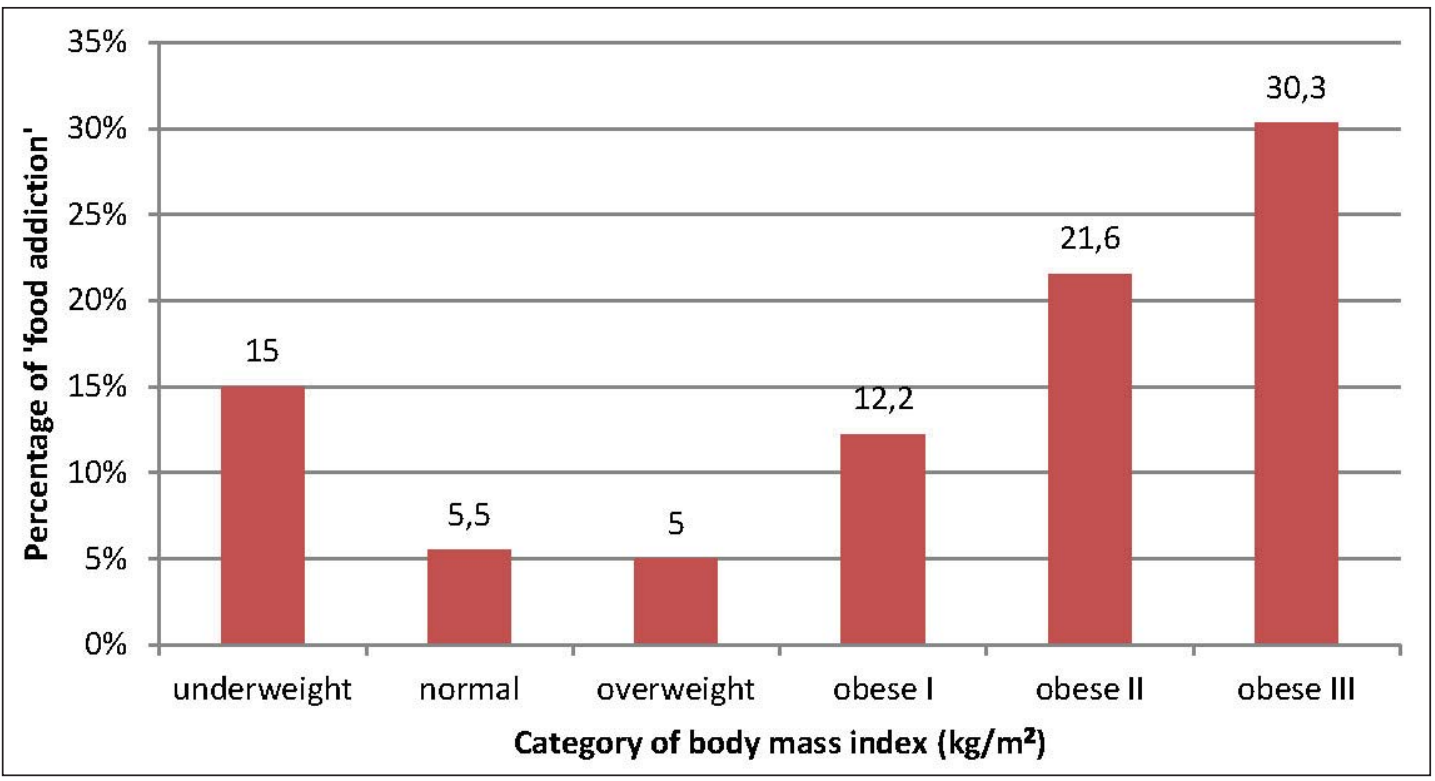

Fig. 1. YFAS 2.0 'food addiction' by weight class.

$\left(\mathrm{r}_{\mathrm{s}}=0.11, \mathrm{p}<0.001\right)$, such that individuals with higher BMI reported elevated symptoms of 'food addiction'. The odds of meeting criteria for YFAS 2.0 'food addiction' was 3 times higher for underweight and 3.5 times higher for obese, when combined into one category, relative to normal-weight participants.

The association of YFAS 2.0 'food addiction' and symptoms with weight category appears to be best represented with a J-shaped curve (fig. 1), elevated endorsement rates of YFAS 2.0 symptoms $(M)$ and greater percentage of individuals meeting the YFAS 2.0 'food addiction' threshold were observed for those categorized as underweight $(M=2.3 ; 15 \%)$ and obese grade I $(M=2.2 ; 12.2 \%)$, obese grade II $(M=3.1 ; 21.6 \%)$ and obese grade III $(M=3.5 ; 30.3 \%)$, compared to normal weight $(M=1.5 ; 5.5 \%)$ and overweight $(M=1.3 ; 5 \%)$.

\section{Symptoms of 'Food Addiction'}

Table 3 furthermore details the prevalence of YFAS 2.0 symptom endorsement in the general sample and according to weight class. In order to preserve clarity within the table, all three obese categories are summed up into one category named 'obese'. Overall, the most frequently met symptoms were as follows: 'loss of control' (19.2\%), 'activities given up' (18.9\%), and 'withdrawal' (18.5\%). The least frequent were 'craving' (11.0\%), and 'tolerance' $(7.4 \%)$. There was variance in symptom endorsement by weight class, with underweight and obese participants endorsing each of the eleven symptoms, as well as clinically significant impairment/distress, more frequently than normal-weight and overweight participants (table 3).

Table 4 illustrates the percentage of individuals with and without YFAS 2.0 'food addiction' that reported each of eleven symptoms, in order to elucidate whether those meeting criteria for YFAS 2.0 'food addiction' exhibit different indicators of addictive-like eating. Among individuals who met the YFAS 2.0 'food addiction' threshold, the most frequent symptoms reported were 'withdrawal' (81.7\%) and 'unsuccessful cut-down' (85.4\%) as well as 'clinically significant impairment/distress' (100\%), though impairment/distress is a required symptom to meet for 'food addiction'. 'Tolerance' (52.5\%) and 'craving' (63.4\%) were the 
Hauck et al.: Prevalence of 'Food Addiction' as Measured with the Yale Food Addiction

Scale 2.0 in a Representative German Sample and Its Association with Sex, Age and

Weight Categories

Table 4. Frequencies of endorsed YFAS 2.0 'food addiction' symptoms, by YFAS 2.0 'food addiction' 'diagnostic' categorization

\begin{tabular}{llllll}
\hline \multirow{2}{*}{ 'Food addiction' criteria measured by YFAS 2.0} & \multicolumn{2}{c}{ 'Food addiction' } & & \multicolumn{2}{c}{ No 'food addiction' } \\
& $\mathrm{n}$ & $\%$ & & $\mathrm{n}$ & $\%$ \\
\hline Loss of control & 64 & 78.0 & & 135 & 14.2 \\
Unsuccessful cut-down & 70 & 85.4 & & 91 & 9.6 \\
Time spent & 57 & 65.5 & & 63 & 6.6 \\
Activities given up & 59 & 72.0 & & 136 & 14.3 \\
Aversive consequences & 63 & 76.9 & & 68 & 7.1 \\
Tolerance & 43 & 52.5 & & 34 & 3.6 \\
Withdrawal & 67 & 81.7 & & 124 & 13.0 \\
Interpersonal problems & 59 & 72.0 & & 130 & 13.7 \\
Impaired daily functioning & 56 & 68.3 & & 123 & 12.9 \\
Dangerous situations & 56 & 68.3 & & 133 & 14.0 \\
Craving & 52 & 63.4 & & 62 & 6.5 \\
Clinically significant impairment & 82 & 100.0 & & 6 & 0.6 \\
\hline
\end{tabular}

least frequent symptoms among individuals with a 'food addiction'. Those participants without 'food addiction' most frequently endorsed 'activities given up' (14.3\%), 'loss of control' (14.2\%), and 'dangerous situations' (14\%) (table 4).

\section{Demographic Data}

Women exhibited a greater prevalence of YFAS 2.0 'food addiction' (9.6\%) than men $(6.3 \%)$, though the overall sex difference was not significant $\left(\chi^{2}(1)=3.74(p=0.053)\right.$. Among underweight participants, only women $\left(\mathrm{n}_{1}=3\right)$ met for YFAS 2.0 'food addiction', and all were classified as severe. Relative to the overall prevalence of YFAS 2.0 'food addiction' in the current sample of 7.9\%, individuals between the ages of 18 and 29 exhibited the highest prevalence of YFAS 2.0 'food addiction', which was $13 \%$. Age was negatively correlated with the number of YFAS 2.0 symptoms endorsed $\left(r_{s}=-0.22 p<0.001\right)$, meaning younger participants reported increased symptomology.

\section{Discussion}

In a German sample, representing a nationally representative subgroup, 7.9\% of individuals $(\mathrm{n}=82)$ met criteria for YFAS 2.0 'food addiction'. In the current sample, the average number of symptoms endorsed was 1.69 out of eleven. These prevalence rates are consistent with community-sample prevalence rates (5-10\%) from previous studies using the original version [23]. Relating this occurrence rate to the total population of Germany, 7.9\% represents more than 4 million German adults (of 51.07 million adult Germans in 2014) [41]. Thus, it appears that 'food addiction', as measured by the YFAS 2.0, might be a relevant phenotype that may contribute to overeating and elevating rates of obesity and eating-related problems.

\section{'Food Addiction' and Weight Category}

The odds of meeting the YFAS 2.0 threshold for 'food addiction' were higher for persons with either underweight or obesity. Of all surveyed underweight participants, $15 \%(n=3)$ met for YFAS 2.0 'food addiction', as did 17.2\% $(n=37)$ of all obese participants. On the other hand, merely $5.5 \%$ of those classified as normal weight and $5 \%$ of all overweight persons met 
Hauck et al.: Prevalence of 'Food Addiction' as Measured with the Yale Food Addiction Scale 2.0 in a Representative German Sample and Its Association with Sex, Age and Weight Categories

YFAS 2.0 criteria. Further, there was a significant association of BMI and YFAS 2.0 'food addiction' and number of YFAS 2.0 symptoms endorsed. Thus, there appears to be a relationship between both low and high BMI and the prevalence of YFAS 2.0 'food addiction'.

The higher YFAS 2.0 'food addiction' prevalence among underweight individuals is unexpected, though consistent with previous work [29]. Notably, in the current study, all three participants with underweight were in the youngest age range (18-29 years old), and their BMIs are within the range for anorexia nervosa according to the DSM-5 [40]. The present findings may reveal an issue regarding the interpretation of the YFAS 2.0 for individuals with restrictive eating behavior. For example, the item 'When I started to eat certain foods, I ate much more than planned' may be endorsed by an individual who restricts their eating or has anorexia nervosa, possibly because the plan was to eat only 100 calories and 200 calories were eaten instead. However, this does not reflect objective overeating that may be endorsed by some individuals with obesity or binge eating disorder. One potential way to reduce variability in interpreting the YFAS 2.0 may be to develop a clinical interview version of the measure, akin to the Eating Disorder Examination [42]. This would allow for exploration of how individuals of varying weight classes conceptualize indicators of addictive-like eating (e.g., consuming more than intended). Based on the present findings, future studies should focus on assessing the validity of the YFAS 2.0 as a measure of 'food addiction' across weight classes, especially in underweight persons.

While obesity and YFAS 2.0 'food addiction' were positively associated, the prevalence rate of YFAS 2.0 'food addiction' was only one in six among obese individuals (17.2\%) suggesting that 'food addiction' may be a contributor to some, but not all forms of obesity. Additionally, akin to other studies of 'food addiction' [37,43], it appears to be prevalent across all weight classes. This suggests that addictive-like eating may represent a unique phenotype of problematic eating behavior that is not synonymous with BMI and obesity. Thus, it will be essential to investigate individual characteristics that contribute to an elevated risk of YFAS 2.0 'food addiction' across weight classes.

\section{Endorsement Rates for 'Food Addiction' Symptoms}

Overall, 'loss of control' (19.2\%), 'activities given up' (18.9\%), and 'withdrawal' (18.5\%) were the three most frequent YFAS 2.0 symptoms endorsed by the current sample.

Loss of control, defined as the frequent consumption of a substance in greater quantities or over longer periods of time than initially intended, appears to be a relevant mechanism in both substance use disorders and eating-related problems like binge eating [40, 44, 45]. In line with the current findings, previous studies have found that 'oss of control may contribute to overconsumption of addictive substances (e.g., alcohol) and certain foods (e.g., high-fat, high-sugar foods) outside the context of a substance use and eating disorder, respectively [46-48]. Thus, loss of control may reflect a more common indicator of problematic eating behavior and may be an appropriate target in interventions.

The second most common symptom was 'giving up important social, occupational, or recreational activities because of eating' (19\%). It has been found that individuals match [49] their food intake to the amount eaten by others in social contexts [50] and perceived intake norms exert a strong bi-directional effect on snack food intake [51]. Similarly, in order to escape social pressure, individuals who exhibit addictive-like eating behavior may avoid social settings where certain foods are freely available. Furthermore this symptom was the most frequently scored for individuals who did not meet YFAS 2.0 criteria (14.3\%) and underweight participants (30\%), which further underscores that this behavior may contribute to subclinical eating-related problems.

The third most commonly reported symptom in the current sample, with $18.5 \%$ endorsement, was 'withdrawal'. Given that withdrawal from certain foods (e.g., sugar) has 
Hauck et al.: Prevalence of 'Food Addiction' as Measured with the Yale Food Addiction Scale 2.0 in a Representative German Sample and Its Association with Sex, Age and Weight Categories

only been examined in animal studies with very high dosages [52], this represents an essential area for future research in humans.

The least frequent symptoms reported overall were 'craving' (11.0\%) and 'tolerance' (7.4\%) (e.g., the need to consume greater quantities of certain foods to achieve a desired effect like reducing negative mood). There has been a long debate about the symptom of craving in the context of addictive disorders [53,54]. In the field of addictive-like eating, craving has been found as one mediator for specific types of foods, BMI, and binge episodes [55]. In the current study, craving was not highly endorsed by individuals meeting criteria for 'food addiction', as assessed by the YFAS 2.0. As a result, this discrepancy warrants examination in future research. Further, low endorsement rates for tolerance have been observed in previous studies examining prevalence of addictive-like eating, measured by the YFAS [15, 56]. Tolerance to certain foods has not been systematically examined, though one study observed diminished reward responsiveness to consumption of ice cream in individuals who reported frequently eating that food, independent of BMI [34]. Thus, future studies should aim to evaluate whether tolerance may develop to certain foods akin to drugs of abuse.

\section{Demographic Data}

No significant sex differences in the prevalence of YFAS 2.0 'food addiction' were observed, though descriptively, women had higher prevalence than men, which is consistent with previous literature [57]. This may be related to data suggesting that German women exhibiting higher rates of eating-related problems than German men [58].

Age was negatively correlated with the number of endorsed YFAS 2.0 'food addiction' symptoms, with highest endorsement rates between the ages of 18 and 29 (13\%). It may be that younger people are more impacted by the modern food environment with abundant availability of calorie-dense food. Research is needed to examine whether individuals meeting criteria for a YFAS 2.0 'food addiction' would benefit from public health initiatives aimed to reduce the influence of the food environment on vulnerable populations, such as implementing restrictions on marketing these foods to younger people or additional taxes.

\section{Limitations}

Although the standard method for representative research was used in the current study, the use of the term 'representative' is an idealization. Thus, while the present results may not directly be generalized to the German population, this study utilizes rigorous methodology to optimize representativeness in research samples.

Anthropometric data of the participants were self-reported and provided by TNS Infratest, but no additional data on physical or psychological conditions were collected, which does not allow the current findings to control for eating disorders (e.g., binge eating disorder) or conditions that may lead to elevated BMI (e.g., medication side effects). This approach also limits the ability to examine the associations between YFAS 2.0 and BMI with other potentially relevant factors like dieting, restraint, weight cycling, or impulsivity. While a strong correlation between eating disorders and addictive-like eating has been observed [23], previous studies have demonstrated that individuals may exhibit YFAS indicators of addictive-like eating without also meeting criteria for an eating disorder and still exhibit clinically significant impairment or distress [27]. Yet, future work is needed to understand the relationship between 'food addiction' and other forms of eating pathology.

Additionally, the current study only examined individuals aged 18-65 years, which limits generalizability of these findings to individuals aged younger or older. Furthermore, the elevated rates of YFAS 2.0 'food addiction' within the BMI category of underweight in the 
Hauck et al.: Prevalence of 'Food Addiction' as Measured with the Yale Food Addiction Scale 2.0 in a Representative German Sample and Its Association with Sex, Age and Weight Categories

present work has to be interpreted with caution, as it might rather reflect symptoms of eating disorders that were not controlled for in this study (e.g., anorexia nervosa). Given that few underweight individuals were included in the current sample, it is difficult to draw conclusions about the potential association between 'food addiction' and low BMI. Further, few studies have been conducted on 'food addiction' concerning underweight people, thus providing only a small data basis for comparative purpose and raising a need for future work. Finally, the present study shows a cross-sectional nature. Therefore no causal statements can be drawn.

\section{Conclusion}

The current study was the first to utilize standard practices for representative research to examine 'food addiction' and its correlates in a large, representative German sample. The present study observed a YFAS 2.0 'food addiction' prevalence of 7.9\% for persons aged between 18 and 65 years, which suggests that addictive-like eating may be a relevant construct for approximately 4 million Germans. YFAS 2.0 'food addiction' 'diagnoses' and symptoms were significantly associated with extreme BMI (underweight and obesity) and younger age, and women exhibited a trend-level higher prevalence of YFAS 2.0 'food addiction' than men. Thus, these findings elucidate groups of individuals that might benefit from prevention and treatment efforts for addictive-like eating. This study also presents the need to investigate how items on the YFAS 2.0 may be interpreted differently by individuals with restrictive eating behaviors, relative to those who struggle with overeating. Finally, this work may motivate future research to evaluate the relationship and potential overlap between 'food addiction' and problematic eating behavior, including eating disorders and obesity.

\section{Author Contributions}

Carolin Hauck and Thomas Ellrott designed the study and acquired data. Carolin Hauck, Annegret Weiß, Adrian Meule, Erica Schulte, and Thomas Ellrott played an important role in interpreting the results. Annegret Weiß played the leading part in analyzing the data. Carolin Hauck, Annegret Weiß, and Erica Schulte drafted the manuscript. All authors revised the manuscript and approved the final version.

\section{Disclosure Statement}

This research was funded by a Fellowship provided by 'Institut Danone - Ernährung für Gesundheit e.V.'. The funders had no role in study design, data collection and analysis, decision to publish or preparation of the manuscript. Data collection was performed by Helmut Leopold/TNS Infratest. The authors declared no conflict of interest, despite the research fellowship provided by Institute Danone. The material is original research and has not been previously published or submitted for publication elsewhere.

\section{References}

1 Mensink GBM, Schienkiewitz A, Haftenberger M, Lampert T, Ziese T, Scheidt-Nave C: Übergewicht und Adipositas in Deutschland: Ergebnisse der Studie zur Gesundheit Erwachsener in Deutschland (DEGS1). Bundesgesundheitsbl Gesundheitsforsch Gesundheitsschutz 2013;56:786-794.

2 Qi L, Cho YA: Gene-environment interaction and obesity. Nutr Rev 2008;66:684-694.

3 Bulik CM, Sullivan PF, Kendler KS: Genetic and environmental contributions to obesity and binge eating. Int J Eat Disord 2003;33:293-298.

4 Taubes G: Demographics: as obesity rates rise, experts struggle to explain why. Science 1998;280:1367-1368

5 Wright SM, Aronne LJ: Causes of obesity. Abdom Imaging 2012;37:730-732. 
Hauck et al.: Prevalence of 'Food Addiction' as Measured with the Yale Food Addiction

Scale 2.0 in a Representative German Sample and Its Association with Sex, Age and

Weight Categories

6 Wadden TA, Butryn ML, Byrne KJ: Efficacy of lifestyle modification for long-term weight control. Obes Res 2004;12(suppl):151S-162S.

7 Meule A: Back by popular demand: a narrative review on the history of food addiction research. Yale J Biol Med 2015;2015:295-302. .

8 Gearhardt AN, Davis C, Kuschner R, D. Brownell K: The Addiction potential of hyperpalatable foods. Curr Drug Abuse Rev2011;4:140-145.

9 Schulte EM, Avena NM, Gearhardt AN: Which foods may be addictive? the roles of processing, fat content, and glycemic load. PLoS One 2015;10:e0117959.

10 Ziauddeen H, Fletcher PC: Is food addiction a valid and useful concept? Obes Rev 2013;14:19-28.

11 Pursey KM, Collins CE, Stanwell P, Burrows TL: Foods and dietary profiles associated with 'food addiction' in young adults. Addict Behav Rep 2015;2:41-48.

12 Smith DG, Robbins TW: The neurobiological underpinnings of obesity and binge eating: a rationale for adopting the food addiction model. Biol Psychiatry 2013;73:804-810.

13 Davis C, Curtis C, Levitan RD, Carter JC, Kaplan AS, Kennedy JL: Evidence that 'food addiction' is a valid phenotype of obesity. Appetite 2011;57:711-717.

14 Avena NM, Gearhardt AN, Gold MS, Wang G, Potenza MN: Tossing the baby out with the bathwater after a brief rinse? The potential downside of dismissing food addiction based on limited data. Nat Rev Neurosci 2012;13: 514; author reply 514.

15 Meule A, Gearhardt AN: Food addiction in the light of DSM-5. Nutrients 2014;6:3653-3671.

16 Avena NM, Rada P, Hoebel BG: Evidence for sugar addiction: Behavioral and neurochemical effects of intermittent, excessive sugar intake. Neurosci Biobehav Rev 2008;32:20-39.

17 Johnson PM, Kenny PJ: Dopamine D2 receptors in addiction-like reward dysfunction and compulsive eating in obese rats. Nat Neurosci 2010;13:635-641.

18 Oswald KD, Murdaugh DL, King VL, Boggiano MM: Motivation for palatable food despite consequences in an animal model of binge eating. Int J Eat Disord 2011;44:203-211.

19 Avena NM, Murray S, Gold MS: Comparing the effects of food restriction and overeating on brain reward systems. Exp Gerontol 2013;48:1062-1067.

20 Avena N, Bocarsly M, Rada P, Kim A, Hoebel B: After daily bingeing on a sucrose solution, food deprivation induces anxiety and accumbens dopamine/acetylcholine imbalance. Physiol Behav 2008;94:309-315.

21 Hoebel BG, Avena NM, Bocarsly ME, Rada P: Natural addiction. J Addict Med 2009;3:33-41.

22 Gearhardt AN, Corbin WR, Brownell KD: Food addiction. J Addict Med 2009;3:1-7.

23 Meule A, Gearhardt AN: Five years of the Yale Food Addiction Scale: taking stock and moving forward. Curr Addict Rep 2014;1:193-205.

24 Gearhardt AN, Corbin WR, Brownell KD: Preliminary validation of the Yale Food Addiction Scale. Appetite 2009;52:430-436.

25 Gearhardt AN, Corbin WR, Brownell KD: Development of the Yale Food Addiction Scale Version 2.0. Psychol Addict Behav 2016;30:113-121.

26 Pursey KM, Stanwell P, Gearhardt AN, Collins CE, Burrows TL: The prevalence of food addiction as assessed by the Yale Food Addiction Scale: a systematic review. Nutrients 2014;6:4552-4590.

27 Gearhardt AN, White MA, Masheb RM, Grilo CM: An examination of food addiction in a racially diverse sample of obese patients with binge eating disorder in primary care settings. Compr Psychiatry 2013;54:500-505.

28 Gearhardt AN, A. White M, N. Potenza M: Binge eating disorder and food addiction. Curr Drug Abuse Rev 2011; 4:201-207.

29 Granero R, Hilker I, Agüera Z, Jiménez-Murcia S, Sauchelli S, Islam MA, Fagundo AB, Sánchez I, Riesco N, Dieguez C, Soriano J, Salcedo-Sánchez C, Casanueva FF, La Torre R de, Menchón JM, Gearhardt AN, FernándezAranda F: Food addiction in a Spanish sample of eating disorders: DSM-5 diagnostic subtype differentiation and validation data. Eur Eat Disord Rev 2014;22:389-396.

30 Murphy CM, Stojek MK, MacKillop J: Interrelationships among impulsive personality traits, food addiction, and body mass index. Appetite 2014;73:45-50.

31 Pivarunas B, Conner BT: Impulsivity and emotion dysregulation as predictors of food addiction. Eat Behav 2015;19:9-14.

32 Gearhardt AN: Neural correlates of food addiction. Arch Gen Psychiatry 2011;68:808.

33 Schulte EM, Grilo CM, Gearhardt AN: Shared and unique mechanisms underlying binge eating disorder and addictive disorders. Clin Psychol Rev 2016;44:125-139.

34 Burger KS, Stice E: Frequent ice cream consumption is associated with reduced striatal response to receipt of an ice cream-based milkshake. Am J Clin Nutr 2012;95:810-817.

35 Murphy CM, Stojek MK, MacKillop J: Interrelationships among impulsive personality traits, food addiction, and Body Mass Index. Appetite 2014;73:45-50.

36 Pivarunas B, Conner BT: Impulsivity and emotion dysregulation as predictors of food addiction. Eat Behav 2015;19:9-14.

37 Meule A, Muller A, Gearhardt AN, Blechert J: German version of the Yale Food Addiction Scale 2.0: prevalence and correlates of 'food addiction' in students and obese individuals. Appetite 2016;DOI: 10.1016/j. appet.2016.10.003.

38 Schulte EM, Tuttle HM, Gearhardt AN: Belief in food addiction and obesity-related policy support. PLoS One 2016;11:e0147557. 
Hauck et al.: Prevalence of 'Food Addiction' as Measured with the Yale Food Addiction Scale 2.0 in a Representative German Sample and Its Association with Sex, Age and Weight Categories

39 World Health Organization (ed): Obesity - Preventing and Managing the Global Epidemic: Report on a WHO Consultation. Geneva, World Health Organization, 2000.

40 Association AP: DSM-5 (2013) // Diagnostic and Statistical Manual of Mental Disorders (DSM- ${ }^{\circledR}$ ), 5 th ed. Washington, American Psychiatric Publishing, 2013.

41 Statistisches Bundesamt.: Bevölkerung - Zahl der Einwohner in Deutschland nach Altersgruppen am 31. Dezember 2014 (in Millionen). http://de.statista.com/statistik/daten/studie/1365/umfrage/bevoelkerungdeutschlands-nach-altersgruppen/, Statista. http://de.statista.com/statistik/daten/studie/1365/umfrage/ bevoelkerung-deutschlands-nach-altersgruppen/ (last accessed January 27, 2017).

42 Fairburn CG: Cognitive Behavior Therapy and Eating Disorders. New York, Guilford Press, 2008.

43 Gearhardt AN, Corbin WR, Brownell KD: Preliminary validation of the Yale Food Addiction Scale. Appetite 2009;52:430-436.

44 Colles SL, Dixon JB, O’Brien PE: Loss of control is central to psychological disturbance associated with binge eating disorder. Obesity (Silver Spring) 2008;16:608-614.

45 Koob GF, Ahmed SH, Boutrel B, Chen SA, Kenny PJ, Markou A, Le O’Dell, Parsons LH, Sanna PP: Neurobiological mechanisms in the transition from drug use to drug dependence. Neurosci Biobehav Rev 2004;27:739-749.

46 Leeman RF, Patock-Peckham JA, Potenza MN: Impaired control over alcohol use: an under-addressed risk factor for problem drinking in young adults? Exp Clin Psychopharmacol 2012;20:92-106.

47 French SA, Jeffery RW, Sherwood NE, Neumark-Sztainer D: Prevalence and correlates of binge eating in a nonclinical sample of women enrolled in a weight gain prevention program. Int J Obes Relat Metab Disord 1999;23:576-585.

48 Everitt BJ, Robbins TW: Neural systems of reinforcement for drug addiction: from actions to habits to compulsion. Nat Neurosci 2005;8:1481-1489.

49 Robinson E, Tobias T, Shaw L, Freeman E, Higgs S: Social matching of food intake and the need for social acceptance. Appetite 2011;56:747-752.

50 Epel ES, Tomiyama JA, Dallmann MF: Stress and reward: neural networks, eating, and obesity; in Brownell KD, Gold MS (eds): Food and Addiction: A Comprehensive Handbook, Oxford, Oxford University Press, 2014, pp 266-272.

51 Robinson E, Benwell H, Higgs S: Food intake norms increase and decrease snack food intake in a remote confederate study. Appetite 2013;65:20-24.

52 Avena NM, Bocarsly ME, Rada P, Kim A, Hoebel BG: After daily bingeing on a sucrose solution, food deprivation induces anxiety and accumbens dopamine/acetylcholine imbalance. Physiol Behav 2008;94:309-315.

53 Kozlowski LT, Wilkinson DA: Use and misuse of the concept of craving by alcohol, tobacco, and drug researchers. Addiction 1987;82:31-36.

54 Cherpitel CJ, Borges G, Ye Y, Bond J, Cremonte M, Moskalewicz J, Swiatkiewicz G: Performance of a craving criterion in DSM Alcohol Use Disorders. J Stud Alcohol Drugs 2010;71:674-684.

55 Joyner MA, Gearhardt AN, White MA: Food craving as a mediator between addictive-like eating and problematic eating outcomes. Eat Behav 2015;19:98-101.

56 Meule A, Rezori V von, Blechert J: Food addiction and bulimia nervosa. Eur Eat Disord Rev 2014;22:331-337.

57 Meule A, Vögele C, Kübler A: Deutsche Übersetzung und Validierung der Yale Food Addiction Scale. Diagnostica 2012;58:115-126.

58 Jacobi F, Höfler M, Strehle J, Mack S, Gerschler A, Scholl L, Busch MA, Maske U, Hapke U, Gaebel W, Maier W, Wagner M, Zielasek J, Wittchen H: Psychische Störungen in der Allgemeinbevölkerung. Nervenarzt 2014;85: 77-87.

59 Gesellschaft für integrierte Kommunikationsforschung mbH \& Co. KG: Berichtsband b4p 2016. Munich, b4p best for planning, 2016, pp 1-323.

60 Statistisches Bundesamt: Mikrozensus - Fragen zur Gesundheit - Körpermaße der Bevölkerung 2013. www. destatis.de/DE/Publikationen/Thematisch/Gesundheit/Gesundheitszustand/Koerpermasse5239003139004. pdf;jsessionid=4937BFCF1364160F41B8AD46314CF352.cae3?_blob=publicationFile (last accessed January $27,2017)$ 
Hauck / Weiß / Ellrott, „Food Addiction”, gezügeltes Essverhalten, mentaler Gesundheitsstatus und Heißhungersymptome bei morbider Adipositas, Adipositas Ursachen, Folgeerkrankungen, Therapie 2016; 10(04): 215-220, DOI: 10.1055/s-00371617719

(C) Schattauer / Thieme Gruppe

Zusammenhang zwischen ,Food Addiction', gezügeltem Essverhalten, mentalem Gesundheitsstatus und Heißhungersymptomen bei morbider Adipositas

English version: Relationship between 'Food Addiction', restrained eating behavior, mental health status and score of binge eating in a morbidly obese German sample

Autoren: Carolin Hauck ${ }^{1}$, Annegret Weiß ${ }^{1}$, Thomas Ellrott ${ }^{1}$

Institut: ${ }^{1}$ Institut für Ernährungspsychologie an der Georg-August Universität Göttingen, Deutschland 


\section{Zusammenfassung}

Aufgrund hoher Prävalenz von Adipositas wird mit ,Food Addiction ${ }^{1}$ ein möglicherweise ursächliches Konstrukt aus dem Formenkreis der Suchterkrankungen erforscht. Dieses Konstrukt basiert in Analogie zu bestehenden Suchterkrankungen auf Kriterien des DSM-5. In vorliegender Studie wurde untersucht, inwieweit ,Food Addiction“ bei morbider Adipositas in Zusammenhang mit gezügeltem Essverhalten, mentalem Gesundheitsstatus und Heißhungerattacken steht. 64 Personen beantworteten Fragen zur Heißhungersymptomatik (analog DSM-5), füllten die Yale Food Addiction Scale (YFAS) 2.0, den erweiterten Fragebogen zum Essverhalten (FEV+) und den Short-Form (SF)-36 aus. 29,7 \% wiesen eine ,Food Addiction“ mit durchschnittlicher Symptomzahl von 3 auf. Der Summenscore rigider Kontrolle (FEV+) konnte die Anzahl an ,Food Addiction'-Symptomen vorhersagen. Die Anzahl an ,Food Addiction'-Symptomen konnte den Summenscore der mentalen Lebensqualität (SF-36) und die Anzahl an Heißhungersymptomen (DSM-5) vorhersagen. Letzteres könnte auf eine relevante Schnittmenge von ,Food Addiction` und Essstörungen hinweisen, so dass weitere Forschung zur Zuordnung von ,Food Addiction“ als eigene, neue oder Teil einer der bestehenden Essstörungen besteht.

\section{Summary}

While the number of obesity is growing, part of the current research is focusing on ,food addiction'('FA') as one potential contributing factor. The construct of 'FA' was developed based on the DSM-5 criteria for substance-related and addictive disorders. This study addresses possible relationships between ' $F A$ ', rigid control of eating behavior, mental health and binges in morbidly obese patients. A total of 64 persons answered questions on binge episodes (DSM-5) and filled in the German versions of the questionnaires Yale Food Addiction Scale (YFAS) 2.0, enlarged Three-Factor Eating Questionnaire (TFEQ+), and Short Form 36 Health Survey (SF-36). The prevalence of 'FA' was $29.7 \%$ with an average amount of three symptoms. The score of rigid control of eating behavior (TFEQ+) was able to predict the symptoms of 'FA'. The amount of 'FA'-symptoms could predict the score of mental health (SF-36) and the amount of binge-symptoms (DSM-5). The latter suggests an overlap between 'FA'- and classic symptoms of existing eating related disorders. Research is needed concerning positioning 'FA' as a distinct or part of an established disorder.

\footnotetext{
${ }^{1}$ Im Beitrag wird durchgehend der etablierte internationale Begriff ,Food Addiction' genutzt. Mögliche deutsche Übersetzungen sind ,Lebensmittelsucht' oder Esssucht'. Deren Gebrauch ist jedoch unüblich.
} 
Schlüsselwörter: Adipositas, ,Food Addiction', YFAS 2.0, Essverhalten

Keywords: obesity, 'Food Addiction', YFAS 2.0, eating behavior

\section{Einleitung}

Derzeit werden neue Erklärungsansätze für die hohen Prävalenzen von Übergewicht und Adipositas in westlichen Industrienationen erforscht [14]. Einer dieser Ansätze ist das Konstrukt einer ,Food Addiction“, die zum Überkonsum an Nahrung beitragen könnte [15]. Der Begriff ,Food Addiction“ wurde in Analogie zu etablierten Suchterkrankungen geschaffen, da Parallelen zwischen übermäßigem Nahrungsmittelkonsum und suchtartigem Verhalten gefunden wurden [15]. Ähnlich einer stoffbezogenen Sucht weisen Menschen mit Adipositas ersten Untersuchungen zufolge auch Veränderungen im dopaminergen System auf, das für das Belohnungssystem zentral ist [27]. Die beobachteten Veränderungen sind assoziiert mit Beeinträchtigungen in Belohnungsempfinden, Konditionierungen, Stressreaktivität, Motivationsanreizen und Eigenwahrnehmung [27]. Auch spezielle Lebensmittel (hohe Konzentrationen an Fett, Zucker und Salz, hochgradig prozessiert) stehen in der Diskussion, möglicherweise ein suchtartiges Potential aufzuweisen [15]. So deuten Forschungsergebnisse von Schulte und Kollegen [23] darauf hin, dass bestimmte hoch prozessierte Lebensmitteln ähnliche pharmakokinetische Eigenschaften wie spezielle Drogen (u.a. Psychostimulanzien, Opiate) aufweisen. Auch in Tierexperimenten mit Ratten konnten unter besonderen Versuchsbedingungen (intermittierender Entzug von Nahrung und Zucker) vergleichbare Handlungsweisen der Versuchstiere beobachtet werden wie bei Applikation von Drogen [3].

Dennoch steht die Forschung zu ,Food Addiction` erst am Beginn und es gibt eine Reihe von wissenschaftlichen Kritikpunkten sowohl an der Validität der Erfassungsmethode, den unscharfen stofflichen Aspekten (Lebensmittel sind Mischungen verschiedenster 
chemischer Stoffe), als auch an der unklaren Begriffsdefinition und der Tatsache, dass bislang kein eindeutiges neurobiologisches Korrelat ermittelt werden konnte [30, 31]. Auch ein Zusammenhang und eine mögliche Überschneidung mit etablierten Essstörungen und gezügeltem Essverhalten werden diskutiert [12]. Es stellt sich darüber hinaus die Frage, welchen potentiellen Mehrwert die Etablierung einer möglichen neuen „Suchterkrankung“ namens ,Food Addiction` für die Therapie von Adipositas oder auch deren Prävention (beispielsweise durch Besteuerung bestimmter Produkte mit nachgewiesen hohem Suchtpotential) haben könnte [31].

Zur Erfassung des Konstrukts ,Food Addiction“ wurde die Yale Food Addiction Scale (YFAS) von einer US-amerikanischen Forschungsgruppe im Jahr 2009 entwickelt und validiert [7]. Die YFAS ist der erste standardisierte Selbstbeurteilungsfragebogen für suchtartiges Essverhalten und basiert auf den diagnostischen Kriterien für substanzbezogene Störungen des diagnostischen und statistischen Leitfadens psychischer Störungen (DSM-IV) [1]. Auf Basis der Veröffentlichung des neuen DSM-5 [2] im Jahr 2013, wurde auch die YFAS adaptiert und erschien 2016 in Version 2.0 (YFAS 2.0) [8]. Sie misst nun elf, statt vormals sieben, verschiedene ,Food Addiction'-Symptome in 35 Fragen auf einer achtstufigen Antwortskala. Zudem wurde der diagnostische Schwellenwert auf zwei (vormals drei) erfüllte Symptome plus klinisch signifikanter Beeinträchtigung herabgesenkt [8].

In einer Meta-Analyse von Studien, welche die vorherige YFAS-Version benutzten, wurde für ,Food Addiction` eine durchschnittliche Prävalenzrate von 19,9 \% gefunden [20], wobei erhöhte Prävalenzraten bei Personen über 35 Jahren, Frauen und Menschen mit Übergewicht beziehungsweise Adipositas gefunden wurden [20]. ,Food Addiction“ war bei Patienten aus klinischen Settings und bei Patienten mit diagnostizierter Essstörung deutlich häufiger vertreten als bei Studienteilnehmern die diese Kriterien nicht erfüllten [20].

Die neue YFAS 2.0 wurde bislang erst in wenigen Studien eingesetzt: In der Validierungsstudie der YFAS 2.0 wurde in der Studienpopulation eine ,Food Addiction“- 
Prävalenzrate von 14,6 \% [8], in einer Studie mit Bulimie-Patienten eine Häufigkeit von $96 \%$ [5], und in den zwei Stichproben, die der deutschen Übersetzungs- und Validierungsstudie zugrunde lagen, eine solche von $10 \%$ [17] ermittelt. In einer bevölkerungsrepräsentativen Erhebung wurde bei 7,9\% der Deutschen eine ,Food Addiction“ festgestellt [9].

Unklar ist derzeit, ob und wie eine ,Food Addiction“, insbesondere bei morbider Adipositas, in Zusammenhang mit gezügeltem Essverhalten, mentalem Gesundheitsstatus und Heißhungerattacken stehen könnte. Zur Schließung dieser Forschungslücke wurden nachfolgende Hypothesen generiert und die vorliegende Studie konzipiert.

\section{Hypothesen}

Eine der psychologischen Dimensionen des menschlichen Essverhaltens ist die kognitive Kontrolle, die vereinfacht das Ausmaß von willentlicher Steuerung des Essverhaltens misst. Bei kognitiver Kontrolle werden rigide oder flexible Strategien unterschieden [18]. Rigide Kontrollmechanismen sind im Gegensatz zu flexiblen Kontrollmechanismen durch dichotome Alles-oder-Nichts-Vorgaben [24] gekennzeichnet, die nach Pudel ,im Umfeld des allgegenwärtigen Nahrungsangebotes zum Scheitern verurteilt sind“" [18]. Rigide Kontrolle geht daher mit einem höheren Body-Mass-Index, einem stärker gestörten Essverhalten und einer schlechteren Gewichtsstabilisierung nach erfolgter Gewichtsreduktion einher [29]. Auch das Konstrukt der ,Food Addiction“ wird mit bestimmten Ausprägungen von Essstörungen assoziiert [5]. So wird vermutet, dass der Summenscore rigider Esskontrolle (ermittelt mit dem ,Three Factor Eating Questionnaire‘ (TFEQ), beziehungsweise dem erweiterten deutschen ,Fragebogen zum Essverhalten“ (FEV+)) die Anzahl an Symptomen einer ,Food Addiction“(YFAS 2.0) vorhersagt.

Die ,Studie zur Gesundheit Erwachsener in Deutschland (DEGS)` zeigte deutlich, dass die gesundheitsbezogene Lebensqualität stark negativ mit dem Auftreten von Krankheiten assoziiert ist [6]. Außerdem wurde eine signifikant negative Assoziation des Rauchens mit 
gesundheitsbezogener Lebensqualität gefunden [21] und auch hoher Alkoholkonsum ging mit geringer gesundheitsbezogener Lebensqualität einher [13]. Zurzeit ist jedoch noch wenig über die gesundheitsbezogene Lebensqualität bei Vorliegen einer ,Food Addiction` bekannt. Sollte die gesundheitsbezogene Lebensqualität durch ,Food Addiction“ beeinflusst werden, so könnte dies für die Existenz eines Krankheitsphänomens (siehe DEGS) sprechen, das durch die YFAS 2.0 abgefragt, und möglicherweise in dem Konstrukt ,Food Addiction` beschrieben wird. Wenn es sich dabei tatsächlich um ein psychologisches Phänomen mit Krankheitswert handeln sollte, müsste die Anzahl an ,Food-Addiction'-Symptomen (YFAS 2.0) folgerichtig den Summenscore der mentalen gesundheitsbezogenen Lebensqualität (SF-36) vorhersagen können. Es wird angenommen, dass dies der Fall ist. Für diese Fragestellung wird der Summenscore der mentalen gesundheitsbezogenen Lebensqualität gewählt (SF-36), da auch die YFAS 2.0 mentale und nicht körperliche Kriterien abfragt.

Studien zeigen, dass die höchsten Prävalenzen von ,Food Addiction` bei Patienten mit Essanfällen, wie Binge-Eating-Störung (BED) oder Bulimia Nervosa (BN), vorliegen [5, 16]. Gekennzeichnet sind diese Erkrankungen unter anderem durch wiederkehrende Episoden von Essanfällen (kurzer Zeitraum, sehr große Nahrungsmenge, Gefühl von Kontrollverlust). Bei Patienten mit BN folgt auf die Essanfälle unangemessenes Kompensationsverhalten, wie selbstinduziertes Erbrechen, Abusus von Pharmaka oder exzessive Bewegung [2]. Bei Patienten mit BED tritt kein Kompensationsverhalten als Reaktion auf Essanfälle auf, so dass BED im Gegensatz zu BN zumeist mit höherem Gewicht assoziiert ist. Adipöse Menschen leiden entsprechend häufiger an BED als an BN [10]. Bei vulnerablen Personen könnte das Auftreten von Essanfällen und Heißhungersymptomen durch bestimmte Lebensmittel begünstigt werden, wenn diese möglicherweise ein suchtauslösendes Potential aufweisen. Dieses könnte dazu beitragen, Heißhungersymptome, Kontrollverlust beim Essen und schließlich Essanfälle auszulösen. So wird vermutet, dass die Symptome einer ,Food 
Addiction“ (YFAS 2.0) in der Lage ist, die Anzahl an Heißhungersymptomen (DSM-5) zu prognostizieren.

\section{Methoden}

\section{Studienteilnehmer und Ablauf der Studie}

Alle Studienteilnehmer wurden im Adipositas-Zentrum einer deutschen Universitätsklinik behandelt. Sie wurden entweder in ein 52-wöchiges konservatives Gewichtsmanagementprogramm (Optifast-52, Nestlé Healthcare Nutrition) eingeschlossen oder bariatrisch-chirurgisch behandelt (Sleeve Gastrectomy oder Omega-Loop-Bypass, auch Mini-Bypass genannt). Kriterien für die Wahl der Therapieform waren vor allem individuelle Bedürfnisse und Dispositionen (z. B. BMI, Komorbiditäten, vorangegangene Therapieversuche), aber auch der persönliche Wunsch der Therapieform. In vorliegende Auswertung wurden Patienten eingeschlossen, die sich im Zeitraum von Juni 2015 bis Juni 2016 im Adipositas-Zentrum vorstellten: $n=64,39 \%$ Männer, Durchschnittsalter 44,6 Jahre $(\mathrm{SD}=12,4)$, durchschnittlicher BMI 46,2 kg/m² $(\mathrm{SD}=8,5)$, davon 79,7 \% mit Adipositas Grad 3.

Im Zuge der klinischen Eingangsdiagnostik wurden Krankheitsgeschichte, Lebenssituation, Medikation, Laborparameter, Blutdruck und anthropometrische Daten aller Patienten erhoben. Teilweise erfolgte eine weitergehende Diagnostik (Gastroskopie, Ultraschall, Röntgen, u.a.). Zur psychologischen Evaluation wurden mittels entsprechender Fragebögen Daten zu ,Food Addiction‘, gezügeltem Essverhalten, Heißhungerattacken und Lebensqualität erfasst. Eingesetzt wurden der YFAS $2.0[8,17]$, der erweiterte Fragebogen zum Essverhalten FEV+ [19, 25] und der Fragebogen zum Gesundheitszustand SF-36 [4, 28], jeweils in deutscher Übersetzung. In vorliegender Studie wurden ausschließlich die im 
Rahmen der klinischen Eingangsdiagnostik erhobenen Daten verwandt und anonymisiert ausgewertet. Dazu wurde das schriftliche Einverständnis der Patienten eingeholt.

\section{Yale Food Addiction Scale (YFAS) 2.0}

Die diagnostischen Kriterien für eine Suchterkrankungen nach DSM-5 [2], die beispielsweise für Alkohol- oder Nikotinsucht gelten, wurden auf suchtartiges Essverhalten übertragen [7] und nun mittels eines neuen Tools, der YFAS 2.0 [8] abgefragt. Die YFAS 2.0 identifiziert suchtartiges Essverhalten anhand von 35 Fragen, mit jeweils acht-stufiger Antwortskala. So werden die elf ,Food Addiction'-Symptome [2] und zudem klinisch signifikante Beeinträchtigung erfasst. Eine ,Food Addiction“ wird „diagnostiziert“ (Begriff nach Gearhardt et al. [8]), wenn mindestens zwei Symptome plus klinisch signifikante Beeinträchtigung vorliegen. Unterteilt wird ,Food Addiction` in die drei Schweregrade mild (2-3 Symptome), moderat (4-5 Symptome) und schwer (6 oder mehr Symptome). In vorliegender Studie wurde die deutsche Version der YFAS 2.0 eingesetzt [17]. Die interne Konsistenz (Kuder-Richardsons Alpha) der elf Symptome lag in dieser Studie bei $\alpha=0,85$.

\section{Fragebogen zum Essverhalten + (FEV+)}

Das Essverhalten der Studienteilnehmer wurde mittels der erweiterten deutschen Version des Three Factor Eating Questionnaire (TFEQ) [25], des Fragebogens zum Essverhalten [19], erfasst. Hier werden grundlegende psychologische Dimensionen des menschlichen Essverhaltens auf den drei Skalen ,Kognitive Kontrolle des Essverhaltens“ (auch ,gezügeltes Essverhalten' genannt), ,Störbarkeit des Essverhaltens‘, und ,Erlebte Hungergefühle‘ abgefragt [19]. Da sowohl kognitive Kontrolle wie auch Störbarkeit als ursächlich für die Entstehung und Aufrechterhaltung von Essstörungen diskutiert werden [19], wurde der FEV zur Überprüfung möglicher Zusammenhänge zwischen Essstörungen und ,Food Addiction` eingesetzt. Der FEV besteht aus 60 Fragen mit zumeist dichotomer Auswahlmöglichkeit (trifft zu, trifft nicht zu). In vorliegender Studie wurde der erweiterte FEV eingesetzt, der die 
Skala zur kognitiven Kontrolle des Essverhaltens zusätzlich in die zwei Subskalen ,Rigide Kontrolle“ und ,Flexible Kontrolle“ unterteilt [29]. Da insbesondere eine rigide Kontrolle des Essverhaltens mit einer erhöhten Anzahl von sogenannten Essanfällen und gestörtem Essverhalten einhergeht [29], stellt sich die Frage, ob ein Zusammenhang zur ,Food Addiction` besteht. Dies soll in vorliegender Studie überprüft werden.

\section{Fragebogen zum Gesundheitszustand (SF-36)}

Die gesundheitsbezogene Lebensqualität der Teilnehmer wurde mittels des Fragebogens zum Gesundheitszustand [4] erhoben, welcher auf dem englischen Short Form-36 (SF-36) von Ware und Kollegen basiert [28]. Der SF-36 besteht aus acht Domänen, unter Anderem Vitalität, allgemeine Gesundheitswahrnehmung oder psychisches Wohlbefinden, die alle gleich gewichtet sind und Werte zwischen 0 - 100 erreichen können. Daraus ergeben sich ein physischer und ein mentaler Summenscore $[4,28]$. Da die gesundheitsbezogene Lebensqualität mit dem Auftreten von speziell chronischen Erkrankungen assoziiert ist [6], wird in vorliegender Studie ein möglicher Zusammenhang mit ,Food Addiction` untersucht.

\section{Heißhungerattacken (Binge Eating, definiert nach DSM-5)}

Zur Messung der Anzahl an Heißhungersymptomen wurden die Diagnosekriterien für Binge Eating, analog DSM-5 [2], abgefragt. Hierzu zählen Menge, Situationen, Kontrolle, Sättigungs- und Völlegefühl und Geschwindigkeit während der Heißhungerattacken oder Essanfälle [2]. Aus den sieben Fragen wurde ein Summenscore gebildet, der in die späteren Berechnungen einfließt.

\section{Datenanalyse}

Die Daten wurden mittels SPSS Versionen 23 und 24 ausgewertet. Normalverteilung wurde für alle relevanten Variablen (BMI, Scores der Fragebögen FEV, YFAS 2.0, Sf-36 und Anzahl der Binge-Eating-Symptome) mit Hilfe des Shapiro-Wilk-Tests geprüft und lag - 
außer bei den Scores zur rigiden Kontrolle - nicht vor. Diese Variablen wurden transformiert (dekadischer Logarithmus). Zur Testung der Hypothesen wurden lineare Regressionsanalysen berechnet, diese wurden sowohl mit den ursprünglichen Variablen als auch den transformierten durchgeführt. Bei den Ergebnissen ergaben sich keine relevanten Unterschiede, so dass hier lediglich die Ergebnisse basierend auf den ursprünglichen Variablen präsentiert werden.

\section{Ergebnisse}

Tabelle 1 zeigt die anthropometrischen Daten der untersuchten Population, die Prävalenz von ,Food Addiction“, die Zahl an ,Food Addiction“-Symptomen und die Ergebnisse der Skalen der Fragebögen FEV+ und SF-36.

Tabelle 1

Anthropometrische Daten der Stichprobe $(n=64)$, Prävalenz YFAS 2.0 ,Food Addiction' und weitere Studienvariablen (eigene Darstellung)

\begin{tabular}{ll}
\hline Variablen & $\begin{array}{l}\text { Mittelwerte der Variablen, } \\
\text { Standardabweichung und Wertebereich }\end{array}$ \\
\hline Alter (Jahre) & $44,55(\mathrm{SD}=12,4 ; 18-68)$ \\
BMI $\left(\mathrm{kg} / \mathrm{m}^{2}\right)$ & $46,18(\mathrm{SD}=8,5 ; 30-72)$ \\
\hline Prävalenz YFAS 2.0 ,Food Addiction' & $\mathbf{2 9 , 7 0 \%}$ \\
\hline Symptomzahl (n) & $3,00(\mathrm{SD}=2,9 ; 0-11)$ \\
Summenscore Heißhunger (n) & $1,86(\mathrm{SD}=2,6 ; 0-7)$ \\
Kognitive Kontrolle (n) & $8,13(\mathrm{SD}=4,3 ; 1-19)$ \\
Störbarkeit (n) & $9,11(\mathrm{SD}=3,5 ; 2-16)$ \\
Hunger (n) & $7,13(\mathrm{SD}=3,8 ; 0-14)$ \\
Flexible Kontrolle (n) & $3,00(\mathrm{SD}=2,7 ; 0-10)$ \\
Rigide Kontrolle (n) & $7,25(\mathrm{SD}=2,8 ; 1-14)$ \\
Physischer Summenscore (n) & $36,70(\mathrm{SD}=12,2 ; 13-59)$ \\
Mentaler Summenscore (n) & $47,18(\mathrm{SD}=12,2 ; 25-68)$ \\
\hline
\end{tabular}


Der durchschnittliche BMI der Gesamtstichprobe lag bei $46,2 \mathrm{~kg} / \mathrm{m}^{2}$, wobei der Großteil der Teilnehmer $(80 \%)$ morbid adipös (BMI > $40 \mathrm{~kg} / \mathrm{m}^{2}$ ) war. Die Gesamtprävalenz von ,Food Addiction` betrug in vorliegender Stichprobe $29,7 \%$. Dabei waren eine leichte $(3,1 \%)$ am seltensten und eine schwere ,Food Addiction` (15,6 \%) am häufigsten vertreten (Abbildung 1). Bei Personen mit Adipositas Grad 1 trat keine ,Food Addiction` auf. Bei Adipositas Grad 2 wurde bei 11,1\%, bei morbider Adipositas sogar bei 35,3\% der Studienteilnehmer eine ,Food Addiction‘ festgestellt (Abbildung 2).

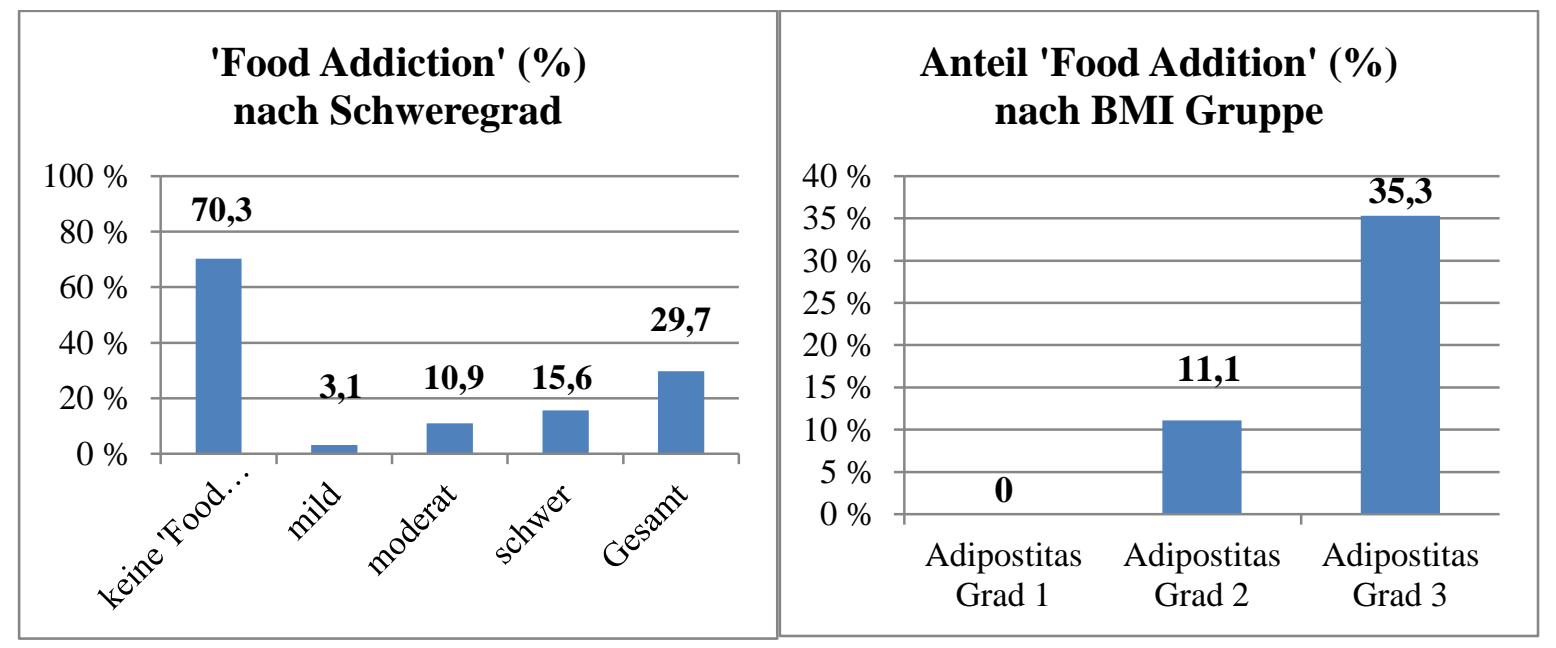

Abbildungen 1/2. Aufteilung von ,Food Addiction“ nach Schweregrad/ nach BMI Gruppe (eigene Darstellung)

Um vorgestellte Hypothesen zu prüfen, wurden lineare Regressionsanalysen durchgeführt und die entsprechenden Korrelationskoeffizienten ermittelt.

Gemäß Hypothese 1 wurden der Summenscore von rigider Kontrolle als Prädiktor und die Anzahl an ,Food-Addiction'-Symptomen als Kriterium verwendet. Rigide Kontrolle konnte die Symptomanzahl signifikant vorhersagen $\left(R^{2}=0,06 ; B=0,26(0\right.$ bis 0,52$) ; S E=0,13 ; p=$ 0,05). Es ergab sich eine kleine, wenngleich signifikante Korrelation zwischen den beiden Variablen $\left(r_{p}=0,24 ; p<0,05\right)$.

In Bezug auf Hypothesen 2 und 3 konnte die Anzahl an ,Food-Addiction'-Symptomen sowohl die Summenscores der mentalen Gesundheit $\left(R^{2}=0,11 ; B=-1,36(-2,36\right.$ bis $-0,36)$; 
$S E=0,5 ; p<0,01)$, als auch die Anzahl der Binge-Eating-Symptome $\left(R^{2}=0,35 ; B=0,51\right.$

$(0,33$ bis 0,69); $S E=0,09 ; p<0,001)$ signifikant vorhersagen. Zwischen den ,Food-

Addiciton'-Symptomen und mentaler Gesundheit bestand eine signifikante negative Korrelation $\left(r_{s}=-0,35 ; p<0,01\right)$. Die Anzahl der ,Food Addiction' und die der Binge-EatingSymptome korrelierten hoch positiv und signifikant miteinander $\left(r_{s}=0,57 ; p<0,001\right)$.

\section{Diskussion}

Nahezu ein Drittel der Patienten (29,7 \%) mit morbider Adipositas wies eine ,Food Addiction` definiert nach YFAS 2.0 auf. In einer für Deutschland repräsentativen Stichprobe betrug die Prävalenz 7,9 \% für die Gesamtpopulation und 17,2 \% in der adipösen Subgruppe (Adipositas Grad 1-3 zusammengefasst), [9]. Adipöse scheinen demnach besonders von suchtähnlichem Essverhalten betroffen zu sein. Dieser Befund wird von weiteren Studien [9, 20] gestützt, in denen eine signifikant positive Korrelation zwischen BMI und ,Food Addiction'-Symptomen festgestellt wurde.

Die Summenscores der Rigiden Kontrolle konnten die Anzahl an ,Food-Addiction“Symptomen signifikant vorhersagen $(p \leq 0,05)$, so dass Hypothese 1 gelten kann. Beide Variablen korrelierten zwar nur schwach positiv, jedoch signifikant miteinander $\left(r_{p}=0,24 ; p\right.$ $<0,05)$. Timko und Perone fanden eine Assoziation zwischen hoher rigider Kontrolle, hohem BMI und erhöhtem Auftreten von Essstörungen [26]. Diese Erkenntnisse könnten für eine sehr enge Beziehung der über die YFAS 2.0 ermittelten Diagnose ,Food Addiction“ mit rigiden Kontrollmechanismen und etablierten Essstörungen sprechen. Nach diesen Befunden könnten rigide Kontrollstrategien eine Schlüsselfunktion in der Genese von Essstörungen, ,Food Addiction“ und auch Adipositas haben. Allerdings bleibt anzumerken, dass in dieser Studie das allgemeine lineare Modell lediglich $6 \%$ der Varianz aufklären $\left(R^{2}=0,06\right)$ konnte, so dass die Ergebnisse derzeit noch mit Vorsicht interpretiert werden müssen und es weiterer Forschung auf diesem Gebiet bedarf. 
Hypothese 2 wurde ebenso bestätigt, da die Anzahl an ,Food-Addiction'-Symptomen den Summenscore von mentaler Lebensqualität in der Stichprobe signifikant vorhersagen konnte $(p<0,01)$. Bei einer Steigerung der ,Food-Addiction'-Symptomzahl um eine Einheit sank der Summenscore des subjektiven mentalen Gesundheitszustandes um mehr als eine Einheit $(B=-1,36)$. Suchtartiges Essverhalten steht also in inversem Zusammenhang mit mentaler Lebensqualität. Dies kann durch den bereits beschriebenen Zusammenhang von suchtartigem Essverhalten, Essstörungen und Adipositas bedingt sein [9, 20]. Da morbide Adipositas generell mit starkem subjektivem Leid, geminderter Lebensqualität [11] und einer Reihe von psychischen Komorbiditäten einhergeht [22], ist der offenbar negative Einfluss von ,Food-Addiction'-Symptomen auf den mentalen Gesundheitszustand von adipösen Menschen klinisch hoch relevant und sollte in zukünftigen Studien hinsichtlich Pathologie und Therapie der Adipositas berücksichtigt werden. Auf Grund des relativ geringen Anteils der aufgeklärten Varianz von nur $11 \%\left(R^{2}=0,11\right)$ bleibt jedoch festzustellen, dass die Aussagekraft des Resultats in weiteren Studien bestätigt werden muss.

Schließlich kann auch Hypothese 3 als bestätigt betrachtet werden, da die Anzahl der ,Food-Addiction'-Symptome die Anzahl an Heißhungersymptomen (definiert nach DSM-5) signifikant vorhersagen konnte $(p<0,001)$. Das angewandte Modell konnte $35 \%$ der Varianz aufklären $\left(R^{2}=0,35\right)$. Es zeigte sich, dass pro ,Food-Addiction'-Symptom die Anzahl an Heißhungersymptomen um 0,5 Symptome anstieg $(B=0,51)$. Ergänzt wurden die Ergebnisse von der signifikanten und hohen positiven Korrelation $r_{p}=0,59$ der Variablen. Diese Werte weisen darauf hin, dass es bei adipösen Menschen möglicherweise Überschneidungen der beiden Konstrukte Heißhunger(attacken) und ,Food Addiction“ gibt. Dass solche Überschneidungen ebenfalls bei Personen mit Bulimia Nervosa existieren, zeigte eine Studie von de Vries und Meule, die eine klinische Stichprobe hinsichtlich Ausprägung der Essstörung und ,Food Addicition“ untersuchten [5]. Nach diesen Befunden kann der in 
Abbildung 3 beschriebene Zusammenhang zwischen rigider Kontrolle,

Heißhungersymptomen, ,Food Addiction“ und Essstörungen postuliert werden (Abb. 3)

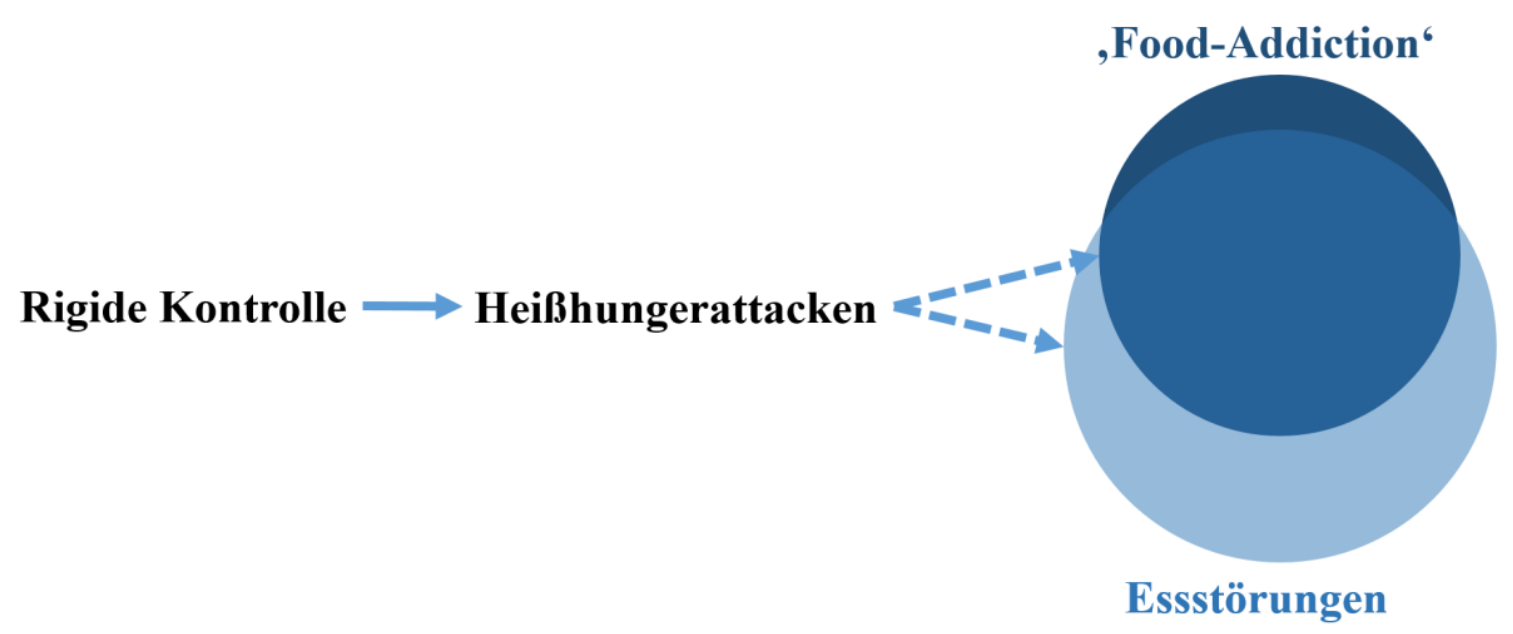

Abbildung 3. Zusammenhang zwischen rigider Kontrolle, Heißhungersymptomen, ,Food Addiction` und Essstörungen (eigene Darstellung)

Dabei stellt sich die Frage, ob das Konstrukt von ,Food Addiction` als eigenständige ,Krankheit` betrachtet werden muss - trotz der erheblichen Überschneidung zu etablierten Krankheiten wie Essstörungen (BN, BED) - oder ob es sich dabei eher um eine Facette einer bereits bestehenden Essstörung handelt. Diese Frage ist von zentraler Bedeutung, da auch bei normalgewichtigen, vor allem aber bei untergewichtigen Personen relevante Prävalenzen von ,Food Addiction` gefunden wurden [9]. Möglicherweise lagen hier ebenso Essstörungen (z.B. Anorexia nervosa $=\mathrm{AN}$ oder $\mathrm{BN}$ ) vor, die aber in den repräsentativen Studien nicht abgefragt wurden. Es gibt bei Untergewichtigen und Normalgewichtigen Forschungsbedarf hinsichtlich der Ausprägung von ,Food Addiction“ in Relation zu parallelen Essstörungen (AN, BN, u.a.). Wäre ein Großteil der Diagnosen von ,Food Addiction“ nach YFAS 2.0 von Essstörungsdiagnosen begleitet, spräche dies klar für ,Food Addiction` als eine Facette von 
Essstörungen. Könnte hingegen nachgewiesen werden, dass bei Untergewichtigen und Normalgewichtigen tatsächlich ein erheblicher Anteil an Personen existiert, der zwar mittels YFAS 2.0 als ,food-addicted‘ klassifiziert werden kann, ansonsten aber keinerlei Essstörungen aufweist, würde dies eher für die Existenz einer ,Food Addiction“ im Sinne einer eigenständigen Störung sprechen.

Unklar ist derzeit auch, wie sich verschiedene Therapieoptionen (ambulante Gewichtsreduktionsprogramme, bariatrische Chirurgie, Pharmakotherapie) im Zeitverlauf auf die Diagnose einer ,Food Addiction“ nach YFAS 2.0 auswirken.

\section{Limitationen}

Da diese Studie ausschließlich die Ausprägung von ,Food Addiction` bei Personen mit erheblicher Adipositas (mittlerer BMI $46 \mathrm{~kg} / \mathrm{m}^{2}$ ) untersucht hat, können die Befunde nicht auf andere Gruppen angewendet und generalisiert werden. Zudem wurde eine noch nicht standardisierte und validierte Erweiterung des FEV verwendet, um die Anzahl an Heißhungersymptomen zu ermitteln. Deren Abfrage folgte aber exakt den Diagnosekriterien des DSM-5 [2]. Es wurden darüber hinaus keine spezifisch standardisierten Tools zur Diagnose von Essstörungen genutzt, sodass aus den eigenen Daten keine Schlussfolgerungen zum diskutierten Zusammenhang von Binge Eating Disorder oder Bulimia nervosa und ,Food Addiction' möglich sind.

\section{Interessenkonflikt}

Die Autoren erklären, dass kein Interessenkonflikt vorliegt.

\section{Ethikkommission}

Die Helsinki-Deklaration wurde eingehalten und die Einwilligung der Patienten nach Aufklärung (informed consent) für die anonymisierte wissenschaftliche Auswertung der im Rahmen der klinischen Diagnostik erhobenen Daten lag vor. 


\section{Literaturverzeichnis}

\section{References}

1. American Psychiatric Association (1994) Diagnostic and Statistical Manual of Mental Disorders, Fourth Edition (DSM-IV). DSM-IV, 4. ed. American Psychiatric Association, Washington DC

2. Association AP (2013) Diagnostic and statistical manual of mental disorders. DSM-5, 5. ed. American Psychiatric Publishing, Washington DC u.a.

3. Avena NM, Rada P, Hoebel BG (2008) Evidence for sugar addiction: behavioral and neurochemical effects of intermittent, excessive sugar intake. Neurosci Biobehav Rev 32(1): 2039. doi: 10.1016/j.neubiorev.2007.04.019

4. Bullinger M, Kirchberger I, Ware J (1995) Der deutsche SF-36 Health Survey Übersetzung und psychometrische Testung eines krankheitsübergreifenden Instruments zur Erfassung der gesundheitsbezogenen Lebensqualität. Übersetzung und psychometrische Testung eines krankheitsübergreifenden Instruments zur Erfassung der gesundheitsbezogenen Lebensqualität. Zeitschrift für Gesundheitswissen 3(1): 21-36. doi: 10.1007/BF02959944

5. de Vries Sarah-Kristin, Meule A (2016) Food addiction and bulimia nervosa: new data based on theYale Food Addiction Scale 2.0. in press. European Eating Disorders Review

6. Ellert U, Kurth BM (2013) Health related quality of life in adults in Germany: results of the German Health Interview and Examination Survey for Adults (DEGS1) (Gesundheitsbezogene Lebensqualitat bei Erwachsenen in Deutschland: Ergebnisse der Studie zur Gesundheit Erwachsener in Deutschland (DEGS1)). Bundesgesundheitsblatt Gesundheitsforschung Gesundheitsschutz 56(5-6): 643-649. doi: 10.1007/s00103-013-1700-y

7. Gearhardt AN, Corbin WR, Brownell KD (2009) Preliminary validation of the Yale Food Addiction Scale. Appetite 52(2): 430-436. doi: 10.1016/j.appet.2008.12.003

8. Gearhardt AN, Corbin WR, Brownell KD (2016) Development of the Yale Food Addiction Scale Version 2.0. Psychol Addict Behav 30(1): 113-121. doi: 10.1037/adb0000136

9. Hauck C, Weiß A, Schulte E et al. ((submitted)) Prevalence of 'food addiction' as measured with the Yale Food Addiction Scale 2.0 in a representative German sample 2 and its association with sex, age and weight categories

10. Herpertz S Adipositas ist mehr als eine Essstörung - die multidimensionale Betrachtung einer Pandemie

11. Kolotkin RL, Meter K, Williams GR (2001) Quality of life and obesity. Obesity Reviews 2(4): 219-229. doi: 10.1046/j.1467-789X.2001.00040.x

12. Long CG, Blundell JE, Finlayson G (2015) A Systematic Review of the Application And Correlates of YFAS-Diagnosed 'Food Addiction' in Humans: Are Eating-Related 'Addictions' a Cause for Concern or Empty Concepts? Obes Facts 8(6): 386-401. doi: 10.1159/000442403

13. Lugger B (2009) „Gesundheitsbezogene Lebensqualität undAlkoholabhängigkeitsrisiko im Zusammenhangmit Kohärenzgefühl und Depression“, Wien

14. Mensink GBM, Schienkiewitz A, Haftenberger M et al. (2013) Overweight and obesity in Germany: results of the German Health Interview and Examination Survey for Adults (DEGS1) (Ubergewicht und Adipositas in Deutschland: Ergebnisse der Studie zur Gesundheit Erwachsener in Deutschland (DEGS1)). Bundesgesundheitsblatt Gesundheitsforschung Gesundheitsschutz 56(5-6): 786-794. doi: 10.1007/s00103-012-1656-3

15. Meule A (2015) Back by Popular Demand: A Narrative Review on the History of Food Addiction Research. Yale J Biol Med 88(3): 295-302 
16. Meule A, Gearhardt AN (2014) Five years of the Yale Food Addiction Scale. Taking stock and moving forward. Curr Addict Rep 1(3): 193-205. doi: 10.1007/s40429-014-0021-z

17. Meule A, Müller A, Gearhardt AN et al. (2016) German version of the Yale Food Addiction Scale 2.0: Prevalenceand correlates of 'food addiction' in students and obese individuals. in press. Appetite

18. Pudel V, Westenhöfer J (2003) Ernährungspsychologie. Eine Einführung, 3., unveränd. Aufl. Hogrefe Verl. für Psychologie, Göttingen

19. Pudel V, Westenhöfer J. (1989) Fragebogen zum Eßverhalten (FEV). Handanweisung

20. Pursey KM, Stanwell P, Gearhardt AN et al. (2014) The prevalence of food addiction as assessed by the Yale Food Addiction Scale: a systematic review. Nutrients 6(10): 4552-4590. doi: $10.3390 /$ nu6104552

21. Rasch A, Greiner W (2009) Rauchen und gesundheitsbezogene Lebensqualität. Ein systematisches Review. SUCHT 55(6): 328-338. doi: 10.1024/2009.06.02

22. Rebscher H, Marschall J, Hildebrandt-Heene S et al. (2016) Schwerpunkt: Gender und Gesundheit Band 13. https://de.statista.com/themen/1318/psychische-erkrankungen/. Accessed 05 Sep 2016

23. Schulte EM, Avena NM, Gearhardt AN (2015) Which foods may be addictive? The roles of processing, fat content, and glycemic load. PLoS One 10(2): e0117959. doi: 10.1371/journal.pone.0117959

24. Stachow R (2004) Flexible Kontrolle als umfassendes Prinzip in der Adipositasschulung. Akutelle Ernährungsmedizin 29 - 86

25. Stunkard AJ, Messick S. (1985) THE THREE-FACTOR EATING QUESTIONNAIRE TOMEASURE DIETARY RESTRAINT, DISINHIBITIONAND HUNGER. Journal of Psychosomatic Research 29(1): 71-83

26. Timko CA, Perone J (2005) Rigid and flexible control of eating behavior in a college population. Eat Behav 6(2): 119-125. doi: 10.1016/j.eatbeh.2004.09.002

27. Volkow ND, Wang G, Tomasi D et al. (2013) Obesity and addiction: neurobiological overlaps. Obes Rev 14(1): 2-18. doi: 10.1111/j.1467-789X.2012.01031.x

28. Ware JE[, Sherbourne CD (1992) The MOS 36-Item Short-Form Health Survey (SF-36): I. Conceptual Framework and Item Selection. Medical Care 30(6): 473-483

29. Westenhoefer J, Stunkard AJ, Pudel V (1999) Validation of the flexible and rigid control dimensions of dietary restraint. Int. J. Eat. Disord. 26(1): 53-64. doi: 10.1002/(SICI)1098108X(199907)26:1<53:AID-EAT7>3.0.CO;2-N

30. Ziauddeen H, Alonso-Alonso M, Hill JO et al. (2015) Obesity and the neurocognitive basis of food reward and the control of intake. Adv Nutr 6(4): 474-486. doi: 10.3945/an.115.008268

31. Ziauddeen H, Fletcher PC (2013) Is food addiction a valid and useful concept? Obes Rev 14(1): 19-28. doi: 10.1111/j.1467-789X.2012.01046.x

\section{Korrespondenzadresse:}

Hauck C, Humboldtallee 32, 37073 Göttingen, Tel. +49 551 398964,

Email carolin.hauck@med.uni-goettingen.de,www.ernaehrungspsychologie.org 


\section{Abbildungs- und Tabellenlegenden}

Abbildung 1. Aufteilung von ,Food Addiction“ nach Schweregrad (eigene Darstellung) Abbildung 2. Aufteilung von ,Food Addiction'nach BMI Gruppe (eigene Darstellung) Abbildung 3. Zusammenhang zwischen rigider Kontrolle, Heißhungersymptomen, ,Food Addiction` und Essstörungen (eigene Darstellung)

Tabelle 1. Anthropometrische Daten der Stichprobe $(n=64)$, Prävalenz YFAS 2.0 ,Food Addiction` und weitere Studienvariablen (eigene Darstellung) 


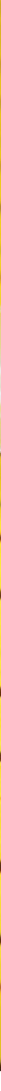

\section{,Food addiction“ \\ - addictive-like eating behavior}

The current state of research with the Yale Food Addiction Scale

Carolin Hauck, Thomas Ellrott

The construct of ,food addiction' is increasingly a subject of focus both in public discussion and in scientific research. The concept of ,food addiction' postulates a link between food intake and addiction. The aim of this article is to give nutrition experts a brief overview of the current scientific discussion, to provide an initial introduction to the complex topic of ,food addiction', and to explain the possible clinical applications of the "Yale Food Addiction Scale" questionnaire (YFAS 2.0). 


\section{Abstract}

There are three methodical research approaches that are used to investigate the construct of a ,food addiction': animal studies, neurocognitive human studies using imaging methods, and questionnaire-based human studies using the Yale Food Addiction Scale (YFAS). The focus of this article will be the current state of research using the YFAS 2.0. Based on the diagnostic criteria for substance addiction set forth in the Diagnostic and Statistical Manual of Mental Disorders (DSM-5), the YFAS assesses and evaluates the psychological aspects of human eating behavior in a standardized manner to determine whether an individual may have an addiction. When ,food addiction' is defined in this way, its prevalence in sample populations is $5-10 \%$. Higher prevalence is observed in patients who are obese, have a binge eating disorder or bulimia nervosa, or who are underweight. Currently, research is being conducted into links between ,food addiction', pathological eating behavior, personality traits (e.g. cognitive control of eating behavior, impulsiveness), and depression. However, the construct of ,food addiction' that is under consideration here is also the subject of criticism because there are still many research gaps that need to be filled in: for example with regard to distinctions and terminology, and with regard to neural and behavioral correlates, and their effects on stigmatization, prevention and therapy. Keywords: food addiction, addictive-like eating behavior, YFAS, obesity, eating disorder

\section{Introduction}

Terms like binge eating disorder, ,food addiction' (e.g. "chocoholic" [1]) and addictive-like eating behavior occur more frequently in German media. These terms link the absolutely crucial food intake with an addiction, as is typical in the case of the consumption of drugs. However, the term "addiction" is often used and understood differently in everyday language than it is in

\section{Citation:}

Hauck C, Ellrott T (2017), Food

Addiction': addictive-like eating behavior. The current state of research with the Yale Food Addiction Scale. Ernahrungs Umschau 64(6): 102-110

This article is available online: DOI: 10.4455/eu.2017.023 scientific literature [2, 3]. In everyday English, "ism" or "holic" suffixes are used synonymously with "addiction" in the sense of an "extreme desire" or an "abnormal reaction" [2] in combination with an active "seeking" for the thing desired [2]. Other examples of everyday terms using such suffixes include shopaholic, workaholic, etc. The word "addicted" is also used in this sense, not necessarily meaning a real medical condition, e.g. "I'm addicted to chocolate (chocoholic [1])".

However, the scientific definition of addiction is much more specific. In DSM-5 (Diagnostic and Statistical Manual of Mental Disorders version 5) [5] "addiction" is classified under the overarching term "addiction and related disorders" and comes under the umbrella of substance use disorders. The term "substance use disorders" includes both substance abuse and substance dependence (according to DSM-IV [4]) [5]. ,Food addiction' is not included in DSM-5, however within specialist circles, it is being discussed as a new aspect of addiction/eating disorders. The purpose of this article is to provide an overview of the discussion as it now stands, and in particular, to provide an overview that is based on the use of the Yale Food Addiction Scale for diagnostics (see "Approaches" section).

The numerous ways in which the term ,food addiction' has been translated into other languages and the various connotations of these different translations illustrate the fact that this phenomenon remains poorly defined. It may be for this very reason that in German scientific literature, the original English term ,food addiction' that was originally proposed by RANDOLPH in 1956 is still being used frequently [6]. Five decades after the term was coined, efforts began to discuss addictive-like eating behavior as a possible explanation for the globally increasing prevalence of obesity. This caused the number of publications on ,food addiction' to increase rapidly $[7,8]$. A comprehensive monograph with the title "Food and Addiction: A Comprehensive Handbook" [9] was published in 2012.

\section{Approaches}

In research, there are three different approaches to the construct of ,food addiction': neurocognitive human studies, animal studies, and questionnaire-based studies.

For the first of these approaches, imaging procedures are used, along with measurement of the hormones and peptides that regulate hunger and satiety, and which are components of the central reward system [10-13]. The main systems at work here are the mesolimbic dopamine system and the cannabinoid and opioid systems [14].

The second approach is animal studies. In these studies, after intermittent deprivation of food and sugar, reactions comparable to the 
reactions after drug consumption were observed in the test animals [15-17]. In special experimental setups, energy-dense, highly processed foods also triggered reactions in humans similar to those described in association with drug abuse (especially loss of control) $[12,14,16,18]$, although significant differences (e.g. no endangerment of others/drug-related crime, no withdrawal symptoms, no sustained dose increases/tolerance development) were reported. In addition, most people do not consume such foods to a pathological extent, and are therefore not "addicted" to them, despite regular consumption [19].

The third scientific approach to ,food addiction' in humans is questionnaire-based studies designed to find overlaps in associated human behaviors. In order to detect, food addiction' in a scientifically valid manner, US researchers developed a questionnaire [20] in 2009, which analyzes addictive-like eating behavior on the basis of the DSM diagnostic criteria for substance dependency [4]. This questionnaire-based method, known as the Yale Food Addiction Scale (YFAS), is already in its second edition, which was published in 2016, and is now known as the Yale Food Addiction Scale 2.0 (YFAS 2.0) [21]. The current version is based on the fifth edition of the DSM (DSM5) [5]. The YFAS has been translated into several languages [22-25]. There is a German version by MeuLE et al. [26]. This self-assessment questionnaire, which has 35 items and an eight-step response scale with options ranging from "never" to "every day", asks questions to determine whether the eleven criteria of substance use disorders according to DSM-5 are met in the context of food intake. These are described in Table 1 and example items are given. The eleven criteria used are also used in DSM-5 for the diagnosis of the more commonly known substance use disorders such as alcohol dependency, cannabis dependency, or gambling addiction. They check all the most relevant categories: loss of control, social impairment, use

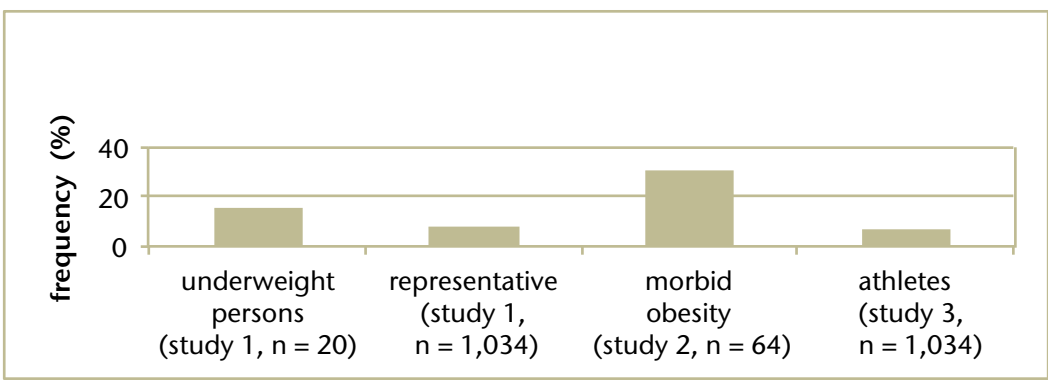

Fig. 1: Prevalence of ,food addiction' assessed by YFAS 2.0 in three different German samples [own data from $(29,31)$ and own unpublished data] YFAS $=$ Yale Food Addiction Scale

that endangers oneself and others, and pharmacological aspects [5]. When two symptoms occur within 12 months along with clinically significant impairment, the criteria for a substance use disorder are considered to be met. In addition, the severity is classified according to three severity grades: mild (2-3 criteria met), moderate ( $4-5$ criteria met) and severe ( $\geq 6$ criteria met) [5]. YFAS 2.0 attempts to transpose the classical criteria for addiction onto human eating behavior in order to detect potentially addictive-like eating behavior in a manner analogous to the technique used for substance use disorders. If this clinically significant impairment is present along with at least two symptoms, ,food addiction' is "diagnosed" according to YFAS 2.0 [20]. In the current version of the YFAS (version 2.0), the behavioral aspect of ,food addiction' is captured and there is no assessment of the foods that are consumed in such situations. Some authors argue that the concept of a ,food addiction' relates specifically to highly processed foods [27], which is why sometimes the term, processed food addiction' is used (see below) [28].

At this point in time, ,food addiction' should be viewed as a scientific suggestion / a scientific construct. It is not an officially recognized diagnosis according to DSM-5. However, due to the standardized YFAS, research into this topic area can be compared on an international level for the first time.

\section{Studies using the Yale Food Addiction Scale}

In a systematic review of studies conducted up to July 2014 using the previous version of the YFAS (version $1.0)$, an average ,food addiction' prevalence of $19.9 \%$ was determined [29]. Here, all English-language studies that measured a YFAS 1.0 diagnosis or symptom score were included, resulting in a sample of nearly 200,000 people who were predominantly female and $60 \%$ of whom were either overweight or obese. Prevalence was higher in women than in men, was higher in people who were overweight/obese than in those of normal weight, and was higher in persons over 35 years of age than in younger people [29]. Studies in students and in population samples showed lower prevalence rates of 5-10\% [30]. Higher rates of prevalence of $15-25 \%$ were observed in studies in obese people. The prevalence in sample populations of patients with morbid obesity (body mass index $[\mathrm{BMI}] \geq 35 \mathrm{~kg} / \mathrm{m}^{2}$ ), binge eating disorder (BED), or bulimia nervosa (BN) was even higher [30]. The most frequently mentioned individual symptom was "unsuccessful attempts to cut down on/control eating", which affected almost $100 \%$ of obese people. The prevalence of the other symptom manifestations varied significantly between the different study populations [30].

In a population-representative study, the prevalence of ,food addiction' in Germany was $7.9 \%$ according to YFAS 2.0 [31] ( Figure 1, study 1). For comparison: according to the World Health 
Organization (WHO) (2014), the prevalence of alcohol abuse in Europe is $7.5 \%$, and the prevalence in Germany is $5.4 \%$ [32]. The proportion of persons with ,food addiction' in the underweight group was 15\% ( $\bullet$ Figure 1, study 1 ). In a sample of subjects with grade 2 or 3 morbid obesity (mean $\mathrm{BMI}=46 \mathrm{~kg} / \mathrm{m}^{2}$ ) at a German university hospital, the prevalence of ,food addiction' according to YFAS 2.0 was $29.7 \%$, and prevalence among those with grade 3 obesity was even higher at $35.3 \%$ [33] ( Figure 1, study 2). Another study conducted in German athletes (inclusion criterion: at least 4 hrs/week of exercise and usually actively in participating in competitions) a ,food addiction' prevalence of $6.3 \%$ was determined according to the YFAS 2.0 (own unpublished data, - Figure 1 , study 3 ).

\section{Manifestation of the YFAS symptoms}

One of the most commonly reported symptoms across all three study populations was "eating more than planned or for longer than planned" (19.2\%, 40.6\%, 19.7\%). In study 2 , the symptom "unsuccessful attempts to cut down on/control eating" was also commonly reported, which lines up with the previous study results [30]. Both of these symptoms indicate that the person in question is having difficulty controlling their food intake.

According to FinLAYSON and DALTON [34], in an everyday environment where highly processed foods that are energy dense and optimized for maximum sensory enjoyment are constantly available and ever present, control of appetite and individual susceptibility to disorders can play a key role in the regulation (or dysregulation) of food intake. A distinction is made between two different systems here: a homeostatic system (hunger, satiety) and a hedonic system (further categorized into taste preferences = liking, and needs = wanting). In the above studies, it was precisely this aspect of controlling eating behavior that

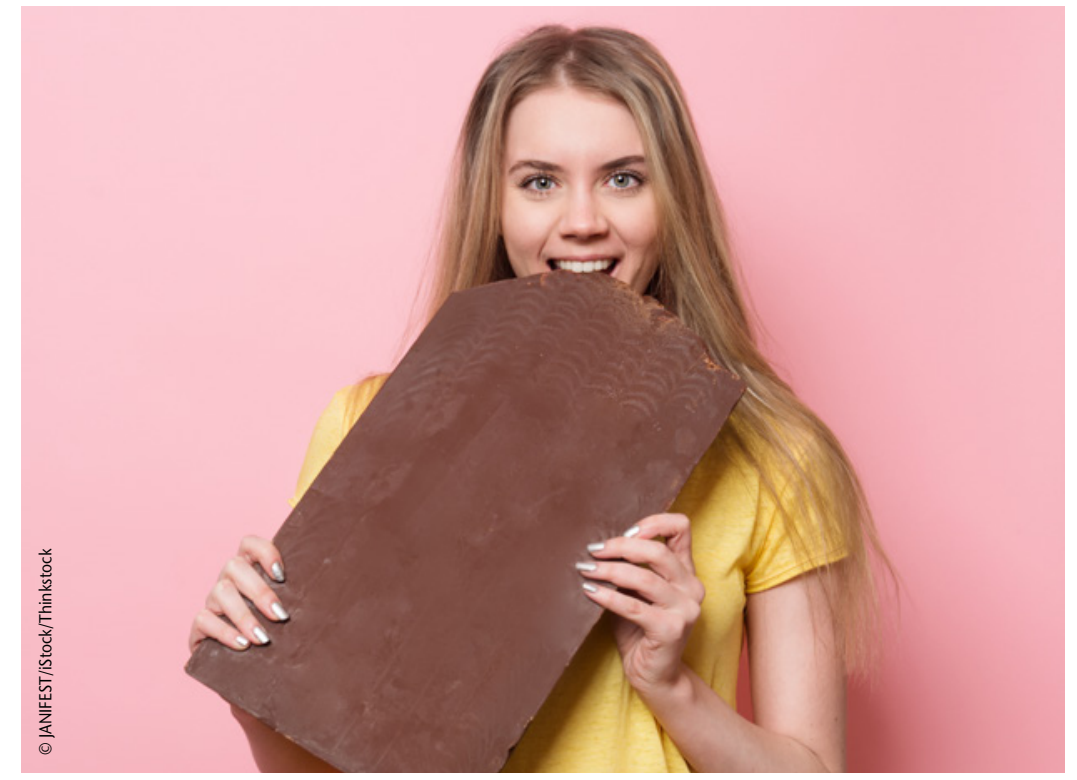

If the person in question is not experiencing any suffering, no diagnosis can be made, regardless of the number of symptoms that are reported. In such cases, no diagnosis of substance use disorder can be made according to DSM-5, and neither can a "diagnosis" of ,food addiction' be made according to YFAS 2.0.

the subjects described as problematic (- Table 1: Manifestation of symptoms). The hedonic system may be involved in weight gain processes and in the development of eating disorders. When this system becomes dysregulated, there is a risk of overconsumption. Possible links with ,food addiction' are discussed in "Hedonics of Food Consumption" [34]. However, the pleasure of eating is also an important component of quality of life [34], and in the opinion of the authors, this should not be forgotten even when considering potential problems to do with the hedonic system.

Studies that have already been conducted show that in people with morbid obesity, the symptom known as "sufferings" (clinically speaking this means significant impairment) was common, with a rate of $35.9 \%$. This criterion plus the manifestation of at least two symptoms form the minimum criteria for substance use disorder ("substance related and addictive disorder" diagnosis) according to DSM-5, and thus also for a "diagnosis" of ,food addiction' according to YFAS
2.0. This means that if the person in question is not experiencing any mental distress, no diagnosis can be made, regardless of the number of symptoms that are reported. Therefore, the probability of a ,food addiction' diagnosis is correspondingly higher in persons who do experience mental distress/sufferings which means that, particularly among the morbidly obese, the probability is much higher than for those of normal weight.

One symptom that seldom manifested in any of the three samples was "development of tolerance" (7.4\%, $17.2 \%, 5.3 \%)$, and this was also demonstrated in other studies [35]. At the time, this group of researchers suspected that an age-related effect was at work here because it is possible that tolerance only develops after several years of addictive-like eating behavior [35]. The sample populations in question were still relatively young, with average ages of: 41 (study 1), 45 (study 2), and 36 (study 3). It remains unclear whether the development of tolerance plays any role in eating behavior, and if it does, to what extent. 


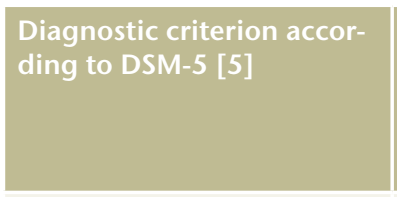

consuming large amounts or consuming for longer than planned (amount)

unsuccessful attempts to cut down on/control food intake (attempts)

large amount of time taken up (time spent)

craving

failing to meet obligations (obligation)

substance use despite social/personal problems (problems)

activities given up

impairment/distress
substance use in physically
hazardous situations

hazardous situations

substance use despite physi$\mathrm{cal} / \mathrm{emotional}$ consequences (consequences)

\section{development of tolerance (tolerance)}

withdrawal symptoms

(withdrawal)

\section{YFAS 2.0 Food Addiction}

YFAS symptom score (mean value, $S D$, measuring range)

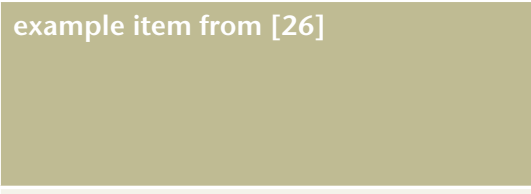

I found that when I started eating certain foods, I ended up eating much more than planned.

I thought a lot about cutting down on certain kinds of food, but I still ate them.

I spent a lot of time feeling sluggish or fatigued from overeating.

I had such a strong desire to eat certain foods that I could no longer think about anything else.

I did not perform well at work or at school because I ate too much.

My friends or family were worried about how frequently I overate.

I consumed certain foods so often or in such large quantities that I gave up other important things. Such things may include working, or spending time with family or friends.

\section{My eating behavior caused me great} distress.

I kept consuming certain foods even though I knew that it was physically dangerous. For example, I continued to eat sweets even though I have diabetes, or I continued to eat fatty foods even though I have heart disease.

I kept consuming the same types of food or the same amount of food even though my eating behavior was causing emotional and/or physical problems.

I found that eating the same amount of food did not bring me the same level of enjoyment as it did before.

I felt irritated, nervous, or sad when I cut down on or stopped eating certain foods.

\section{Frequency \\ within a \\ representative \\ German sample \\ (\%) [29]}

19.2

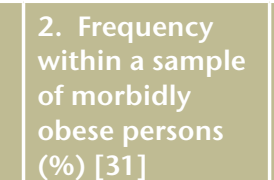

40.6

42.2

15.6

11.6

11.0

20.3

25.0

12.5

18.9

18.3
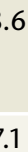

8.5

35.9

7.6

18.3

28.1

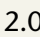

12.7

42.2

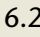

7.4

17.2

5.3

18.5

\begin{tabular}{|c|c|}
\hline $\mathbf{7 . 9}$ & 29.7 \\
\hline 1.69 & 3.00 \\
\hline$(\mathrm{SD}=2.8 ; 0-11)$ & $(\mathrm{SD}=2.9 ; 0-11)$ \\
\hline
\end{tabular}

6.3

0,93

$(\mathrm{SD}=2.0 ; 0-11)$

Tab. 1: Diagnostic criteria according to DSM-5, sample items from YFAS 2.0, and frequency of symptoms in different German samples

Bold print $=$ values mentioned in text

DSM = Diagnostic and Statistical Manual of Mental Disorders; SD = standard deviation; YFAS = Yale Food Addiction Scale 


\section{Links between ,food addic- tion' and other disorders}

A number of research groups are currently discussing parallels between ,food addiction' and obesity, but also between ,food addiction' and eating disorders such as BED or BN $[19,34]$. In studies in patients who have BED or $\mathrm{BN}$, very similar levels of ,food addiction' prevalence have been found [22, 33, 35, 36]. Individuals who had BED additionally experienced cravings for sweet things [37], loss of control with regard to food, and feelings of guilt after binging [38]. The YFAS 2.0 is also used to determine parameters such as cravings, loss of control, and distress, which could mean significant overlaps between ,food addiction' according to YFAS 2.0 and corresponding eating disorders.

This calls into question what the additional benefit of YFAS 2.0 would be. However, DAvIS argues that BED (the most common eating disorder) should be considered separately from ,food addiction' because although there are similarities between the two conditions (compulsive overeating), there are also some important differences. According to DAVIS, addictive diseases are self-sustaining clinical phenomena, and possibly also acquired diseases of the brain [40], whereas BED belongs to the category of psycho-behavioral diseases [39]. Not all BED patients meet the criteria for ,food addiction', and the same is true vice versa. Patients who do not have BED, but who do have a ,food addiction' according to YFAS 2.0 might also exhibit grazing behavior - i.e. continuous food intake in small portions and not in the form of episodic binges involving large amounts of food. The two forms of consumption, episodic and continuous, are also found in other addictive diseases (e.g. alcoholism) [39].

According to current research results, various personality traits can also influence eating habits. The focus here is on impulsiveness, depression, cognitive control, and ex-

\section{Glossary}

craving = a strong urge or desire to consume a food (or drug) [5]

grazing $=$ repeating episodes of consumption of small quantities of food over a long period, with the feeling of loss of control [41]

wanting = need, appetite; involves the appetite center, the stimulus and the motivation to eat something [42]

liking = preference, inclination; involves the concept of pleasure and taste [42]

(1)

treme craving attacks [31, 43, 44]. It was found that obese people and those with BED exhibited elevated levels of food-related impulsive behavior [45, 46]. DAvis et al. observed higher levels of manifestation of impulsiveness, addictive personality traits, and cravings among people with ,food addiction' and BED [8] than in those who did not have ,food addiction' or BED. Meule and colleagues also demonstrated [43] that there is a link between some aspects of impulsiveness and addictive-like eating behavior in obese people. Pathological eating behavior was observed particularly in obese people who were in a negative mood [47]. In addition, among the morbidly obese patient group prior to or after bariatric surgery, depression was the most common mental illness [48]. Based on this, ScHAG et al. concluded that impulsiveness, depression, and pathological eating behavior are closely related [44].

In a separate study, the total score for rigid control (control of food intake without leaving room for deviations in behavior), measured by using the extended German version of the Three Factor Eating Questionnaire, the "erweiterter Fragebogen zum Essverhalten" [extended questionnaire on eating behavior] (FEV+) [49-51], was successfully used as an indicator to predict the number of symptoms of ,food addiction' [33]. Individuals who exhibited restrictive eating behavior also manifested higher levels of wanting compared to those who did not restrict their food intake, whereas liking was manifested to a similar extent across both groups. Based on this, VEENSTRA and DE Jong [52] concluded that wanting, and thus also automatic approach tendencies, play a more important role in eating behavior than simple taste preferences. Likewise, the number of ,food addiction' symptoms was successfully used as an indicator to predict both the sum of the scores for mental quality of life as measured by the short-form (36) health questionnaire (SF-36) $[53,54]$, and the number of extreme craving attack symptoms according to DSM-5 [5] [33].

- Figure 2 outlines the described relationships between rigid control, impulsiveness, depression, extreme craving attacks, restriction, and eating disorders/,food addiction'.

\section{Criticism of the concept of ,food addiction'}

The construct of ,food addiction' itself, as described here, has been the subject of criticism [55-57]. Some of the aspects that are criticized include that there is no universally acknowledged definition of the term $[55,58]$, and that the results are partially based on animal studies in a context of extreme hunger and that the applicability of findings from such studies to humans is questionable [59]. The YFAS/YFAS 2.0 questionnaire instrument itself is also criticized because it is not clear what exactly the YFAS/YFAS 2.0 measures. In addition, only one 


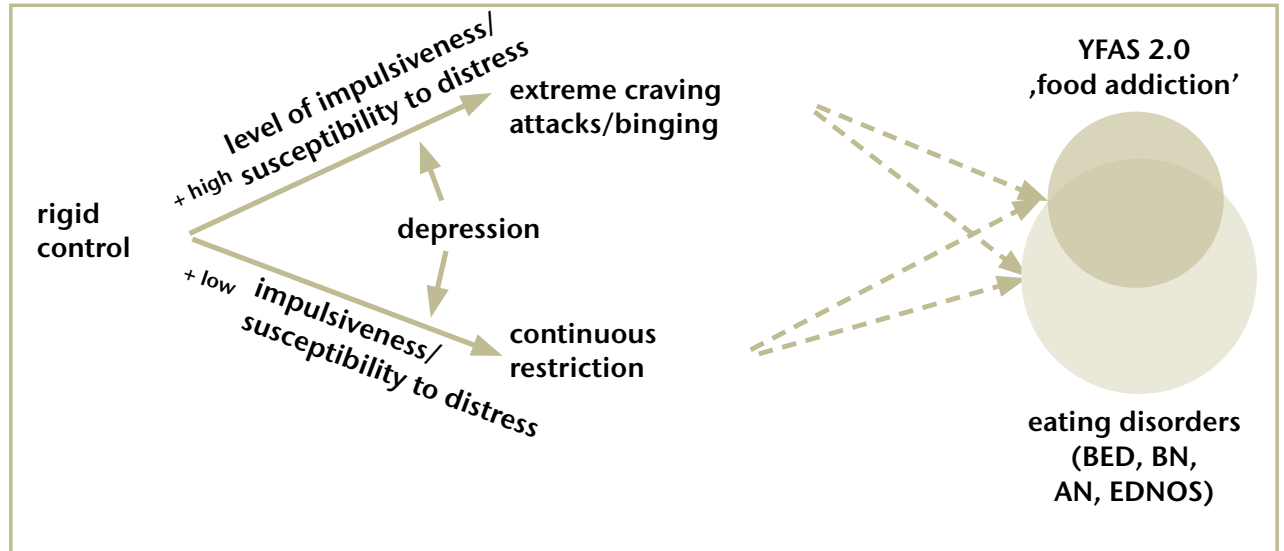

Fig. 2: Postulated link between individual behavioral traits, eating disorders, and ,food addiction' (mod. according to [33])

$\mathrm{AN}$ = anorexia nervosa; $\mathrm{BED}$ = binge eating disorder; $\mathrm{BN}=$ bulimia nervosa; EDNOS = eating disorder not otherwise specified; YFAS = Yale Food Addiction Scale

in six obese people meet the criteria for ,food addiction', along with a certain percentage people of normal weight and a comparatively high proportion of those who are underweight, as well as those who exhibit binge eating behavior [60]. The working group of ALBAYRAK and HEBEBRAND has also discussed whether ,food addiction' is a substance-based addiction, or rather a behavioral addiction [61-63]. In addition, many of the clinically significant eating disorder-related problems can be explained and treated without the need to apply an additional addiction concept. Indeed, making these problems synonymous with addictive disorders could even cause further pathologies, instead of helping to cure them [59, 60, 64].

However, scientists who support the ,food addiction' concept argue that the findings from animal models are comparable to human behaviors in the context of eating disorders [58, 65] and the heterogeneity of the results is due to differences in the stimuli and not due to discrepancies at the neural level [66]. In their article "Clearing the confusion around processed food addiction" [28], IFLAND and colleagues argue that at the very least, further research should be conducted into food addiction, despite all of the criticism. They themselves suggest that the concept of ,food addiction' should be more precisely termed ,processed food addiction" because it is primarily based on the addictive use of highly processed products which are not considered to be necessary for survival, but which may cause non-transmissible diseases (e.g. obesity or type 2 diabetes) [28]. They argue that humans must eat for survival and that eating cannot be simply avoided as in the case of the consumption of other substances (e.g. alcohol) according to the abstinence principle. However, this essential food intake could be achieved entirely without the use of highly processed, energy-dense products, which lead to addictive symptoms as per the ,processed food addiction' model. From this, IfLAND and colleagues conclude that, processed food addiction' should be taken seriously, and that public campaigns aimed at limiting the availability of highly processed and energy-dense foods should be launched in order to successfully effect change as was previously achieved with campaigns against alcohol and tobacco [28]. However, there have been no studies on the feasibility or benefits of such campaigns.

Another separate issue is that the ,food addiction' construct may contribute to a reduction in stigmatization, as found by LATNER et al. in a study. Trial subjects stigmatized obese people less when they were told about ,food addiction' beforehand [67].

\section{Conclusions}

,Food Addiction' suggests that there is a proximity between everyday food intake and addiction in the sense of disorders or diseases. Unlike recognized addictive substances such as cocaine or alcohol, a healthy body is absolutely dependent on a sufficient intake of energy and nutrients, as these are vital for survival. ,Food addiction' in the sense of a general substance consumption disorder would thus pathologize a basic human need. For this reason, the question of whether the term ,food addiction' should be changed to ,processed food addiction' is currently being discussed. The YFAS does not allow any conclusions to be drawn with regard to any substance-related aspects because the current version 2.0 only records behavioral aspects, and not the foodstuffs consumed in the respective situations. It is indisputable that there are people within the population whose eating behaviors cause them distress, and that such eating behaviors must be considered pathological. These behaviors include the eating disorders anorexia nervosa, $\mathrm{BN}$ and BED, which are already recognized in DSM-5. It is possible that food addiction, as determined by YFAS 2.0, is another additional independent eating disorder that is particularly close to behavioral addiction: A behavior that is in fact physiologically necessary (in this case, eating) is misused by those affected by the condition in a pathological manner in order to force positive feelings (similar to gambling addiction, shopping addiction, or sex addiction). In light of the fact that ,food addiction' according to YFAS 2.0 overlaps to a large extent with the diagnoses of $\mathrm{BN}$ and $\mathrm{BED}$ and possibly also anorexia nervosa, it is clear that more research into 
the distinctions between these conditions is needed. It is questionable whether ,food addiction' actually occurs and has clinical significance among groups who have no concomitant eating disorders. According to the current state of knowledge, a ,food addiction' diagnosis using YFAS 2.0 can often be considered an aspect of classical eating disorders (• Figure 2). Rigid control strategies for food intake that leave no room for deviations in behavior appear to be typical of both classical eating disorders and ,food addiction' (- Figure 2). It is possible that both ,food addiction', according to YFAS 2.0, and eating disorders could be prevented using flexible control strategies that leave room for deviations in behavior such as occasional overshooting of basic set limits.

In humans, YFAS research has provided the first findings on pathological eating behavior. However, more research is still needed in order to establish a new DSM-5 diagnosis. What is needed is more precise analyses, universally recognized definitions of terms, and studies with hard endpoints. Furthermore, the effects that a new ,food addiction' diagnosis could have on prevention and treatment, public health, stigmatization and the individual's situation, remains unclear.

For this reason, the clinical use of the YFAS 2.0 for "diagnosis" of ,food addiction' cannot yet be recommended. The questionnaire should (for the time being) continue to be considered a purely scientific instrument that cannot be used as evidence to reach conclusions with regard to preventative measures or treatment.

Carolin Hauck M.Sc. ${ }^{1,2}$

PD Dr. Thomas Ellrott ${ }^{1,3}$

${ }^{1}$ Institut für Ernährungspsychologie an der Georg-August-Universität Göttingen Humboldtallee 32, 37073 Göttingen 2E-Mail: carolin.hauck@med.uni-goettingen.de ${ }^{3}$ E-Mail: thomas.ellrott@med.uni-goettingen.de

\section{Conflict of Interest}

The Institut für Ernährungspsychologie an der Universität Göttingen [Institute for Nutrition and Psychology at University of Goettingen] received funding from Danone Ernährung für Gesundheit e. V. [Danone Nutrition for Health Institute] for conducting a study on the subject of food addiction.

\section{References}

1. Hetherington MM, Macdiarmid JI (1993) Chocolate addiction': a preliminary study of its description and its relationship to problem eating. Appetite 21: 233-246

2. Stangl W. Sucht \& Drogen, Lernen. [werner stangl]s arbeitsblätter (2016) URL: http:// arbeitsblaetter.stangl-taller.at/SUCHT/ Zugriff 12.06.16

3. Bibliographisches Institut GmbH. DUDEN. URL: www.duden.de/rechtschreibung/Sucht Zugriff 12.08.16

4. American Psychiatric Association ( $\mathrm{Hg}$ ). Diagnostic and statistical manual of mental disorders: DSM-IV ; includes ICD-9-CM codes effective 1. Oct. 96. 4. ed., 7. print, Washington DC (1998)

5. American Psychiatric Association ( $\mathrm{Hg}$ ). Diagnostic and statistical manual of mental disorders: DSM-5. 5. ed., American Psychiatric Publ., Washington DC (2013)

6. Randolph TG (1956) The descriptive features of food addiction; addictive eating and drinking. Q J Stud Alcohol 17: 198-224

7. Gearhardt AN, Davis C, Kuschner R, Brownell KD (2011) The addiction potential of hyperpalatable foods. Curr Drug Abuse Rev 4: 140-145

8. Davis C, Curtis C, Levitan RD et al. (2011) Evidence that 'food addiction' is a valid phenotype of obesity. Appetite 57: 711-717

9. Brownell KD, Gold MS (Hg). Food and addiction: a comprehensive handbook. Oxford University Press, Oxford (2012)

10. Wang GJ et al. (2001) Brain dopamine and obesity. Lancet 357: 354-357

11. Schienle A, Schäfer A, Hermann A, Vaitl D (2009) Binge-eating disorder: reward sensitivity and brain activation to images of food. Biol Psychiatry 65: 654-661

12. Volkow ND, Wang GJ, Tomasi D, Baler $R D$ (2013) The addictive dimensionality of obesity. Biol Psychiatry 73: 811-818

13. Volkow ND, Wang GJ, Tomasi D, Baler RD (2013) Obesity and addiction: neurobio- logical overlaps: Overlaps between drug and food addiction. Obes Rev 14: 2-18

14. Carter $A$ et al. (2016) The neurobiology of 'food addiction' and its implications for obesity treatment and policy. Annu Rev Nutr 36: 105-128

15. Avena NM, Bocarsly ME, Rada $P$ et al. (2008) After daily bingeing on a sucrose solution, food deprivation induces anxiety and accumbens dopamine/acetylcholine imbalance. Physiol Behav 94: 309-315

16. Avena NM, Rada P, Hoebel BG (2008) Evidence for sugar addiction: behavioral and neurochemical effects of intermittent, excessive sugar intake. Neurosci Biobehav Rev 32: 20-39

17. Hoebel BG, Avena NM, Bocarsly ME, Rada P (2009) Natural addiction: a behavioral and circuit model based on sugar addiction in rat. J Addict Med 3: 33-41

18. Smith DG, Robbins TW (2013) The neurobiological underpinnings of obesity and binge eating: a rationale for adopting the food addiction model. Biol Psychiatry 73: 804-810

19. Davis C, Carter JC (2009) Compulsive overeating as an addiction disorder. A review of theory and evidence. Appetite 53: 1-87

20. Gearhardt AN, Corbin WR, Brownell KD (2009) Food addiction: an examination of the diagnostic criteria for dependence. J Addict Med 3: 1-7

21. Gearhardt AN, Corbin WR, Brownell KD (2016) Development of the Yale Food Addiction Scale Version 2.0. Psychol Addict Behav 30: 113-121

22. Granero $R$ et al. (2014) Food addiction in a Spanish sample of eating disorders: DSM-5 diagnostic subtype differentiation and validation data: food addiction and ED subtypes. Eur Eat Disord Rev 22: 389-396

23. Brunault $P$ et al. (2017) Validation of the French version of the DSM-5 Yale Food Addiction Scale in a nonclinical sample. Can J Psychiatry 62: 199-210

24. Innamorati $M$ et al. (2015) Psychometric properties of the Italian Yale Food Addiction Scale in overweight and obese patients. Eat Weight Disord - Stud Anorex Bulim Obes 20: 119-127

25. Swarna Nantha Y, Abd Patah NA, Ponnusamy Pillai $M$ (2016) Preliminary validation of the Malay Yale Food Addiction Scale: factor structure and item analysis in an obese population. Clin Nutr ESPEN 16: 42-47

26. Meule A, Müller A, Gearhardt AN, Blechert $J$ (2016) German version of the Yale Food 
Addiction Scale 2.0: prevalence and correlates of 'food addiction' in students and obese individuals. Appetite [in press]

27. Schulte EM, Avena NM, Gearhardt AN (2015) Which foods may be addictive? The roles of processing, fat content, and glycemic load. PLOS ONE 10: e0117959

28. Ifland J, Preuss HG, Marcus MT et al. (2015) Clearing the confusion around processed food addiction. J Am Coll Nutr 34: 240-243

29. Pursey K, Stanwell P, Gearhardt A et al. (2014) The prevalence of food addiction as assessed by the Yale Food Addiction Scale: a systematic review. Nutrients 6: 4552-4590

30. Meule A, Gearhardt AN (2014) Five years of the Yale Food Addiction Scale: taking stock and moving forward. Curr Addict Rep 1: 193-205

31. Hauck C, Weiß A, Schulte EM et al. (2017) Prevalence of 'food addiction' as measured with the Yale Food Addiction Scale 2.0 in a representative German sample and its association with sex, age and weight categories. Obes Facts 10: 12-24

32. World Health Organization. Alcohol consumption: levels and patterns - Germany (2014)

33. Hauck C, Weiß A, Ellrott T (2016) Relationship between "food addiction", restrained eating behavior, mental health status and score of binge eating in a morbidly obese German sample. Adipositas 10: 215-220

34. Finlayson G, Dalton M (2012) Hedonics of food consumption: are food 'liking' and 'wanting' viable targets for appetite control in the obese? Curr Obes Rep 1: $42-49$

35. Meule A, von Rezori V, Blechert J (2014) Food addiction and bulimia nervosa: food addiction and bulimia nervosa. Eur Eat Disord Rev 22: 331-337

36. Barry D, Clarke M, Petry NM (2009) Obesity and its relationship to addictions: is overeating a form of addictive behavior? Am J Addict 18: 439-451

37. Kampov-Polevoy AB, Alterman A, Khalitov E, Garbutt JC (2006) Sweet preference predicts mood altering effect of and impaired control over eating sweet foods. Eat Behav 7: 181-187

38. Ricca V et al. (2009) Correlations between binge eating and emotional eating in a sample of overweight subjects. Appetite 53: 418-421

39. Davis C (2016) A commentary on the associations among 'food addiction', binge eating disorder, and obesity: overlapping conditions with idiosyncratic clinical features. Appetite [in press]

40. Volkow ND, Koob GF, McLellan AT (2016) Neurobiologic advances from the brain dis- ease model of addiction. $N$ Engl J Med 374: 363-371

41. Saunders R (2004) Grazing': a high-risk behavior. Obes Surg 14: 98-102

42. Berridge KC (1996) Food reward: brain substrates of wanting and liking. Neurosci Biobehav Rev 20: 1-25

43. Meule A, de Zwaan M, Müller A (2017) Attentional and motor impulsivity interactively predict 'food addiction' in obese individual. Compr Psychiatry 72: 83-87

44. Schag K et al. (2016) The impact of impulsivity on weight loss four years after bariatric surgery. Nutrients 8: 721

45. Schag K, Schönleber J, Teufel $M$ et al. (2013) Food-related impulsivity in obesity and binge eating disorder - a systematic review: food-related impulsivity. Obes Rev 14: 477-495

46. Houben K, Nederkoorn C, Jansen A (2014) Eating on impulse: the relation between overweight and food-specific inhibitory control: food-specific inhibition and overweight. Obesity 22: E6-E8

47. Leehr EJ, Krohmer K, Schag K et al. (2015) Emotion regulation model in binge eating disorder and obesity - a systematic review. Neurosci Biobehav Rev 49: 125-134

48. Malik S, Mitchell JE, Engel S et al. (2014) Psychopathology in bariatric surgery candidates: a review of studies using structured diagnostic interviews. Compr Psychiatry 55: 248-259

49. Pudel V, Westenhöfer J. Fragebogen zum Eßverhalten (FEV). Hogrefe (1989)

50. Stunkard AJ, Messick S (1985) The three-factor Eating Questionnaire to measure dietary restraint, disinhibition and hunger. J Psychosomolic Research 29: 71-83

51. Westenhoefer J, Stunkard AJ, Pudel V (1999) Validation of the flexible and rigid control dimensions of dietary restraint. Int J Eat Disord 26: 53-64

52. Veenstra EM, de Jong PJ (2010) Restrained eaters show enhanced automatic approach tendencies towards food. Appetite 55: 30-367

53. Ware JE, Sherbourne CD (1992) The MOS 36-item short-form health survey (SF-36). I. Conceptual framework and item selection. Med Care 30: 473-483

54. Bullinger M, Kirchberger I, Ware J (1995) Der deutsche SF-36 Health Survey Übersetzung und psychometrische Testung eines krankheitsübergreifenden Instruments zur Erfassung der gesundheitsbezogenen Lebensqualität. J Public Health 3: 21-36

55. Ziauddeen H, Farooqi IS, Fletcher PC (2012) Obesity and the brain: how convincing is the addiction model? Nat Rev Neurosci 13: 279-286

56. Ziauddeen H, Farooqi IS, Fletcher PC (2012) Food addiction: is there a baby in the bathwater? Nat Rev Neurosci 13: 514-514

57. Ziauddeen H, Fletcher PC (2013) Is food addiction a valid and useful concept? Obes Rev 14: $19-28$

58. Meule A, Kübler A (2012) The translation of substance dependence criteria to food-related behaviors: different views and interpretations. Front Psychiatry 3: 1-2

59. Rippe JM (2014) Lifestyle medicine: the importance of firm grounding on evidence. Am J Lifestyle Med 8: 306-312

60. Corwin RLW, Hayes JE (2014) Are sugars addictive? Perspectives for practitioners. In: Rippe $J M(H g)$. Fructose, high fructose corn syrup, sucrose and health. New York, Springer New York (2014), S. 199-215

61. Albayrak Ö, Kliewer J, Föcker $M$ et al. (2015) Food Addiction: Nahrungsmittelabhängigkeit oder Ess-Verhaltenssucht? Z für Kinder-Jugendpsychiatrie Psychother. 43: 173-183

62. Albayrak Ö, Wölfle SM, Hebebrand J (2012) Does food addiction exist? A phenomenological biscussion based on the psychiatric classification of substance-related disorders and addiction. Obes Facts 5: 165-179

63. Albayrak Ö, Hebebrand J (2015) Ist EssSucht eine Verhaltenssucht? PPmP - Psychother Psychosom Med Psychol 65: 39-41

64. Benton D (2010) The plausibility of sugar addiction and its role in obesity and eating disorders. Clin Nutr 29: 288-303

65. Meule A (2014) Are certain foods addictive? Front Psychiatry 5: 1-3

66. Avena NM, Gearhardt AN, Gold MS et al. (2012) Tossing the baby out with the bathwater after a brief rinse? The potential downside of dismissing food addiction based on limited data. Nat Rev Neurosci 13: 514-514

67. Latner JD, Puhl RM, Murakami JM, O'Brien KS (2014) Food addiction as a causal model of obesity. Effects on stigma, blame, and perceived psychopathology. Appetite 77: 79-84

DOI: 10.4455/eu.2017.023 
Hauck / Ellrott, Zusammenhänge zwischen Genuss und Übergewicht/Adipositas, Adipositas - Ursachen, Folgeerkrankungen, Therapie 2017; 11(04): 192-197 DOI: 10.1055/s0038-1624221

(C) Georg Thieme Verlag KG Stuttgart · New York

\section{Zusammenhänge zwischen Genuss und Übergewicht/Adipositas}

Relationships between pleasure and overweight/obesity

Carolin Hauck, Thomas Ellrott

Institut für Ernährungspsychologie an der Georg-August-Universität Göttingen, Göttingen (Institutsleiter: PD Dr. Thomas Ellrott) 


\section{Zusammenfassung:}

Der Begriff „Genuss“ beschreibt eine als angenehm und positiv bewertete Sinneswahrnehmung. Er wird meist im Kontext von Essen und Trinken verwendet. Das Erlernen und Erleben von kulinarischem Genuss wird auch von Ernährungsfachgesellschaften als wichtiger Bestandteil einer gesunderhaltenden Ernährung und zur Aufrechterhaltung positiver Stimmung, Lebensqualität und Gesundheit propagiert. Die hier dargestellten in Deutschland erhobenen Daten zeigen, dass dem Essen im Lebensalltag ein hoher GenussStellenwert zugesprochen wird. Für genussvolles Essen sind danach besonders guter Geschmack und Zeit/Ruhe/Entspannung notwendig. Auch schätzen sich die Deutschen zu mehr als $80 \%$ selbst als Genießer ein. Genießer haben wiederum eine höhere Lebenszufriedenheit und ein höheres Wohlbefinden. Ein signifikanter Zusammenhang zwischen Body-Mass-Index (BMI) und Genuss wurde nicht gefunden, allenfalls ein Trend für eine geringere Genussfähigkeit bei Menschen mit Übergewicht/Adipositas im Vergleich zu Normalgewichtigen. Die Selbsteinschätzung als „Genießer“ unterschied sich nicht zwischen den BMI Kategorien. Die Aufnahme eines speziellen Genuss- und Achtsamkeitstrainings in die S3-Leitlinie zur Prävention und Therapie der Adipositas könnte möglicherweise zu einer Verbesserung des Outcomes in Gewichtsreduktionsprogrammen führen.

\section{Summary:}

In the German language, the term "Genuss (pleasure)" describes a positive sensory perception. It is mostly used in the context of food and beverages. Nutritional societies recommend learning and experiencing culinary pleasure as it is an important component of health-promoting nutrition and to maintain positive mood, quality of life and health. The German data show that eating plays an important role when comparing pleasure levels of daily activities. The Germans assess good taste and time/rest/relaxation to be necessary parameters for pleasurable eating. More than $80 \%$ self-assess as gourmets. In general, gourmets show a higher satisfaction with life and higher well-being. No significant association was found between BMI and pleasure. There was only a trend for lower pleasure levels in daily activities in overweight and obese individuals compared to normal-weight individuals. The self-description as gourmet did not differ between BMI categories. Probably an inclusion of training in pleasure and mindfulness in the German guidelines to prevent and treat obesity may improve weight loss outcomes.

Schlüsselwörter: Genuss, Lebenszufriedenheit, Übergewicht, Adipositas

Keywords: pleasure, satisfaction with life, overweight, obesity 


\section{Einführung}

„Gesundheit ist ein Zustand des vollständigen körperlichen, geistigen und sozialen Wohlbehagens/Wohlbefindens und nicht nur das Fehlen von Krankheit oder Gebrechen.“ (33) Bereits vor mehr als 50 Jahren stellte die Weltgesundheitsorganisation (33) das Wohlbefinden des Menschen in den Mittelpunkt ihrer Definition von Gesundheit. Neben einer körperlichen Dimension gehören dazu gleichwertig auch eine geistige und soziale Dimension, die im klinischen Alltag oft übersehen werden (33). Für das Wohlbefinden spielen angenehme beziehungsweise als vom Individuum positiv bewertete Sinneseindrücke eine wichtige Rolle. Eine positive Sinnesempfindung, die mit körperlichem und/oder geistigem wie auch teilweise sozialem Wohlbefinden verbunden ist, wird typischerweise als „Genuss“ bezeichnet.

Wie korrelieren Genuss und Lebenszufriedenheit in Deutschland? Welche Rolle spielt Genuss beim Essen? Gibt es einen Zusammenhang zwischen Genuss und Gesundheit und möglicherweise auch zwischen Genuss und Körpergewicht? Diese Fragen im Kontext von Genuss werden nachfolgend diskutiert.

\section{$\underline{\text { Wortbedeutung }}$}

Ursprünglich bedeutete das Wort „genießen“ zweckorientiert die „nutznieszung“ (2), „der nutzen dessen was man von irgend einem gute genieszt“ (17) oder ,genusz einer wohlthat, Adelung“(17). Auch der Genosse als Mitglied einer Gemeinschaft basiert auf der Wortbedeutung der „gemeinsame(n) nutznieszung des gemeinen grund und bodens“ (17). Das deutsche Wörterbuch der Brüder Grimm beschreibt erstmals einen darüber hinausgehenden hedonistischen Nutzen wonach „das hauptgewicht auf die lust““ (18) fiel. Eine zusätzliche Einengung in der Verwendung des Begriffes vor allem im Kontext von Essen und Trinken führte letztlich zur heutigen Begriffsbedeutung (18): Der aktuelle Duden führt als Synonyme zu Genuss zunächst Verzehr und danach Freude, Lust und Vergnügen auf (6). Die kulinarische Assoziation steht heute im Vordergrund. Genuss wird aber auch weiterhin für andere angenehme nicht essensbezogene Sinnesempfindungen verwendet. Diese sind zum Beispiel Lesen, Musik, Reisen, Sport oder auch Wellness und Entspannung. Ein ausgeprägter kulinarischer Genießer wird in der Alltagssprache häufig als Feinschmecker oder Gourmet bezeichnet. Frühe empirische Daten zeigten Genuss bereits sehr positiv konnotiert und als eine Form der menschlichen Wertorientierung (21). Der genussbezogene Typus ist demnach ein „sensitives, emotionales Wesen“ (21), das einen „sinnlich akzentuierten, freudebetonten 
Lebensstil“" (21) führt. Neben der Alltagsverwendung wird der Begriff Genuss im Sinne einer Hedonie auch in der klinischen Psychologie und der Verhaltenstherapie genutzt (28).

\section{$\underline{\text { Hintergrund }}$}

Genuss im Zusammenhang mit Essen und Trinken wird ab der Geburt in einem lebenslangen soziokulturellen Lernprozess geprägt, erlernt und verändert. Neugeborene bevorzugen im Rahmen einer angeborenen Süßpräferenz vor allem süß schmeckende Lebensmittel. Auch Kleinkinder bevorzugen eher noch milde Geschmacksrichtungen, bevor dann im Laufe der Entwicklung zunehmend scharfe und bittere Noten auch $\mathrm{zu}$ genussvollem Empfinden beitragen können. Dazu zählen Kaffee, schwarzer Tee und Alkohol. Diese Lebensmittel gelten, neben kakaohaltigen Süßwaren wie Schokolade, als klassische Genussmittel (5). Klassische Genuss-Lebensmittel enthalten die psychotropen Substanzen Alkohol, Koffein, Teein und Theobromin, die pharmakologisch zum Genusserlebnis, zur Anregung, Entspannung und angenehmen Stimmung beitragen können. Essen bedeutet zwar einerseits die Zufuhr von essentiellen Nährstoffen, um das Überleben zu sichern, aber auch Bedürfnisbefriedigung, Sinneserfahrungen und Genuss (15). Genuss zu erlangen wird als erstrebenswert angesehen, da Genießen vor Stress im Alltag schützen, zu Wohlbefinden, zu seelischer Balance, sowie zu erhöhter Lebensqualität beitragen soll (27). Auch die Deutsche Gesellschaft für Ernährung hat die Bedeutung von Genuss in zwei ihrer zehn Regeln für eine ausgewogene und gesunderhaltende Ernährung aufgegriffen (12). In der aktuellsten 10. Auflage aus dem Jahr 2017 wird bereits in der ersten Regel empfohlen, die Lebensmittelvielfalt zu genießen (12). Die 9. Regel greift Genuss noch einmal auf, indem sie „Achtsam essen und genießen“ (12) propagiert. Im Vorwort des BMEL-Ernährungsreports 2016 erklärte Bundesminister Christian Schmidt, dass bewusster Genuss für die Deutschen von großer Bedeutung sei, sie die hohe Qualität der Lebensmittel schätzen und sich gezielt informieren (9). Haenel unterscheidet fünf Faktoren von Genuss, die in den folgenden Abschnitten teilweise erläutert werden: physiologisch, sensorisch, psychisch, sozial und hygienisch (20). 


\section{Physiologische Aspekte}

Eine Genussempfindung kann physiologisch über verschiedene Mechanismen ausgelöst werden: zum einen über die Wahrnehmung und positive Bewertung von Geruch und Geschmack $(1 ; 10)$ und zum anderen über direkte pharmakologische Wirkungen. Bei ersterem Weg werden u.a. Moleküle von Aromastoffen in den Lebensmitteln an der Riechschleimhaut detektiert (1), als neuronales Signal weitergeleitet und v.a. im Limbischen System/Nucleus Accumbens/ventralen Striatum bewertet (1). Eine positive Bewertung führt u.a. zu einer vermehrten Ausschüttung von ACTH und Dopamin. Diese Botenstoffe erzeugen positive Gefühle im Belohnungssystem, die letztlich als Genuss empfunden werden (23). Drogen wie (Ethanol), Kokain oder Nikotin gelangen über den Blutkreislauf direkt in das Gehirn, wo sie unmittelbar auf das Dopaminsystem einwirken $(1 ; 10)$. Es ist wahrscheinlich, dass positive Empfindungen, die im Kontext mit sozialer Gemeinschaft entstehen, auch über das $\mu$-OpioidSystem vermittelt werden (24). Zudem vermittelt das Hormon Oxytocin soziale Bindungen über angenehme Empfindungen sowie eine beruhigende, stressreduzierende und deeskalierende Wirkung (13). Da Genuss beim Essen besonders häufig in sozialer Gemeinschaft erlebt wird (s.u.), dürften gemeinsame Mahlzeiten so mittelbar auch über die letztgenannten zentralen Systeme auf das Individuum einwirken.

\section{$\underline{\text { Psychologische Aspekte }}$}

Das Genießen wird psychologisch der Euthymie (griechisch euthymía, zu: eúthymos = fröhlich, zu: eũ = gut, wohl und thymós = Gemüt) zugeordnet, was ausgeglichene Stimmungslage, Heiterkeit und Frohsinn bedeutet (28). Welche Verhaltensweisen diese Stimmung beeinflussen, ist individuell verschieden und kann zum Beispiel körperliche Aktivität, gute Gespräche, Musik oder auch ein wohlschmeckendes Essen bedeuten. Auch Emotionen und Erinnerungen beeinflussen die Wahrnehmung von Genuss. Dabei spielt das limbische System eine wichtige Rolle für die schnelle und unbewusste Bewertung verschiedener Sinneseindrücke. Eine rationale Bewertung geschieht häufig erst im Nachhinein (7). Um Genuss erleben zu können, bedarf es verschiedener psychologischer Voraussetzungen bzw. Verfassungen. Diese wurden 1983 von Lutz und Koppenhöfer in Form von sieben Genussregeln postuliert (29):

1. Genuss braucht Zeit.

2. Genuss und Genießen muss erlaubt sein. 
3. Genuss geht nicht nebenbei.

4. Weniger ist mehr.

5. Aussuchen, was einem gut tut.

6. Ohne Erfahrung kein Genuss.

7. Genuss ist alltäglich.

Exemplarisch kann die erste Regel „Genuss braucht Zeit“ am Beispiel von Schokolade erläutert werden. Diese muss sich erst im Mund erwärmen und schmelzen, damit eine physikalisch-chemische Wahrnehmung mit verschiedenen Sinnen im Mund-, Nasen- und Rachenraum beginnen kann. Aromarelevante Moleküle müssen freigesetzt werden und orthonasal oder retronasal zu den Riechzellen diffundieren, erst dann kann die Schokolade in ihrer Vollständigkeit wahrgenommen und genossen werden (28). Die zweite Regel „Genuss und Genießen muss erlaubt sein“ bedeutet, dass Genuss gewollt und akzeptiert sein muss um Genuss wirklich erfahren zu können. Dieser Genussregel stehen jedoch teilweise Genussverbote und Sinnsprüche, wie: „Erst die Arbeit, dann das Vergnügen“ entgegen. Diese machen eine euthyme Ausgeglichenheit bisweilen schwer erreichbar (27).

In Studien war der Begriff Genuss meist stark positiv assoziiert und führte dazu, entsprechende sinnliche Erfahrungen in Erinnerung zu rufen, aber auch zukünftige genussvolle Erlebnisse vorstellbar zu machen (4). Dennoch rief der Begriff Genuss nicht ausschließlich positive Gedanken hervor, da mit Genuss teilweise auch „übermäßiger Genuss“ assoziiert war, welcher negativ konnotiert ist (30). Genießer zeichnen sich dadurch aus, dass sie Situationen aufsuchen, in welchen sie angenehme Erfahrungen machen können. Dadurch erfahren sie positive Verstärkung (26). Bergler konnte auf Basis qualitativer Interviews vier Dimensionen von Genuss herausarbeiten: Zeit, Bewusstheit, Geld und Harmonie (4). Er resümiert, dass Genuss nicht einen flüchtigen Moment angenehmer Gefühle darstellt, sondern als Gesundheitsressource langfristig wirken und die Gesundheit schützen kann (5).

\section{$\underline{\text { Genuss und Gesundheit }}$}

Gruber und Kollegen untersuchten Zusammenhänge zwischen Genuss und Gesundheit in einer repräsentativen Studie in Österreich. Als Basis der Gesundheitsdefinition fungierte die bereits zuvor genannte Darlegung der Weltgesundheitsorganisation (33). Bergler postulierte 2002, dass Genuss ein wichtiger Faktor körperlichen Wohlbefindens sei und mit geringeren bis gar keinen körperlichen Beschwerden korreliere (5). Die Studienergebnisse von Gruber 
aus dem Jahr 2006 bestätigten diesen Zusammenhang. Genuss scheint ein wichtiger Baustein von Lebensqualität zu sein 14). Denn Genießen hebt die Stimmung, erhöht die Wahrnehmung, steigert die Produktivität und trägt damit zu höherer Lebensqualität, Ausgeglichenheit, Leistungsfähigkeit und Stressresistenz beziehungsweise Resilienz bei (14). Dagegen korrelierte ein eingeschränktes Genusserleben mit einer Vielzahl an Krankheiten wie Bluthochdruck oder koronaren Herzerkrankungen und war auch mit erhöhtem BMI assoziiert (5). Laut Gruber spielt auch „gesunde Ernährung“ eine wichtige Rolle zur Erhaltung von Gesundheit (19). All diese Aspekte wurden in die aktuelle Studie (s.u.) einbezogen.

\section{$\underline{\text { Genuss und Körpergewicht }}$}

Personen mit Gewichtsproblemen berichten häufig von Schwierigkeiten, ihre Nahrungsaufnahme zu kontrollieren und ihre Kalorienaufnahme anzupassen. Klassische energiereduzierte Diäten operieren häufig mit rigiden und genussfremden Vorgaben und machen damit das Essen zum Feind (32), was diese Problematik statt sie zu lösen weiter verstärken könnte. Frauen und Männer mit Übergewicht oder Adipositas trauen sich deshalb häufig nicht, Essen und Trinken zu genießen, Genuss zuzulassen und Genuss zu erleben, obwohl sie sich oft mit Essen beschäftigen. Dieses Paradox wird darin deutlich, dass Personen mit geringerem BMI besser genießen können, weniger Gewichtsprobleme haben, einen besseren Gesundheitsstatus aufweisen und sich insgesamt wohler fühlen (19). Personen mit erhöhtem BMI dagegen genießen tendenziell weniger, haben häufiger ein schlechtes Gewissen beim Essen und weisen einen schlechteren Gesundheitsstatus auf, was einer Negativspirale entspricht (19). Genießen zu können, hilft demnach unter Anderem zur Erzielung eines besseren Gesundheitsstatus als auch zur Aufrechterhaltung eines normalen Körpergewichtes (19). Einen Erklärungsansatz für das unterschiedliche Genusserleben kann auch die zeitliche Komponente geben, denn je länger eine Nahrungsdeprivation vorliegt, desto höher wird der Essgenuss eingeschätzt (22). Dies konnte durch Daten aus Österreich bestätigt werden, denn Personen, die häufiger verzichten, konnten Genuss besser auf Dauer bewahren (19).

\section{Die Deutsche Genussstudie 2017}

\section{Material und Methoden}


Bergler kritisierte, dass empirische Studien zu den Modalitäten des Erlernens von Genuss und zu möglichen Auswirkungen von Genuss beim Essen auf Wohlbefinden und Lebensqualität fehlen, obgleich Genuss als protektiver Faktor für den Erhalt von Gesundheit angesehen werde (5). Neue Daten hierzu liefert eine repräsentative Studie für die Altersgruppe 18-69 Jahre aus dem Jahr 2017. Die Stichprobe war repräsentativ in Bezug auf Geschlecht, Region, Ortsgröße, Familienstand und Bildung. Das Marktforschungsunternehmen Kantar TNS befragte 1034 Personen zu verschiedenen Aspekten von Genuss und zum Zusammenhang zwischen Genuss und Wohlbefinden, Lebenszufriedenheit und Körpergewicht. Die Studienteilnehmer beantworteten in einer Online-Befragung 31 Fragen inkl. Körperlänge und Körpergewicht (Selbstauskunft). Der selbstentwickelte Fragebogen beinhaltete die deutsche Version der Satisfaction with Life Scale (SWLS) (16) zur Messung der Lebenszufriedenheit, den Fragebogen zum Wohlbefinden (WHO-5) (8; 2; 3) zur Messung des Wohlbefindens, die Erfassung und Einordnung von 24 genussvollen Verhaltensweisen auf einer fünfstufigen Likert-Skala, eine offene Frage zu genussvollem Essen, die Selbsteinschätzung als Genießer auf einer sechsstufigen Likert-Skala, die Einschätzung weiterer essensbezogener Verhaltensweisen und die Selbsteinschätzung des Gesundheitswertes der eigenen Ernährung auf einer vierstufigen Likert-Skala. Der durchschnittliche BMI der Stichprobe lag bei 26,2 $\mathrm{kg} / \mathrm{m}^{2}$, der Anteil von Personen mit Übergewicht betrug 34,1 \%, der von Personen mit Adipositas $18,1 \%$.

\section{$\underline{\text { Statistische Auswertung }}$}

Statistisch ausgewertet wurden die Daten mittels der Programme IBM SPSS Statistics Version 24.0 und Microsoft Excel 2010. Zur deskriptiven Datenanalyse wurden Mittelwerte (MW), Mediane (Mdn) und Korrelationen berechnet. Um übergewichtige/adipöse und normalgewichtige Personen sowie selbstdefinierte Genießer und Nicht-Genießer zu vergleichen, wurden kategorialen Daten mittels Chi-Quadrat-Tests und kontinuierliche Daten mittels Mann-Whitney-U-Tests, jeweils auf dem Signifikanzniveau von $p<.05$ berechnet. 


\section{Ergebnisse}

\section{Genussvolle Verhaltensweisen}

Um den Stellenwert von Essen und Trinken für Genuss im Lebensalltag einschätzen zu können, wurden die Befragten zunächst gebeten, 24 Tätigkeiten und Verhaltensweisen des Alltags nach ihrem Genusswert auf einer Skala von 1-5 zu gewichten ( 1 = kein Genuss, $5=$ höchster Genuss). „Zuhause toll essen“ steht bei den Deutschen an dritter Position und rangiert knapp hinter „Entspannen/Ausruhen/Schlafen“ und „Urlaub machen“. Danach folgen „Zeit mit der Familie verbringen“ und „Zeit draußen verbringen“ (siehe Abb. 1).

Abbildung 1: Die Top 5 Verhaltensweisen der Deutschen mit dem höchsten Genuss

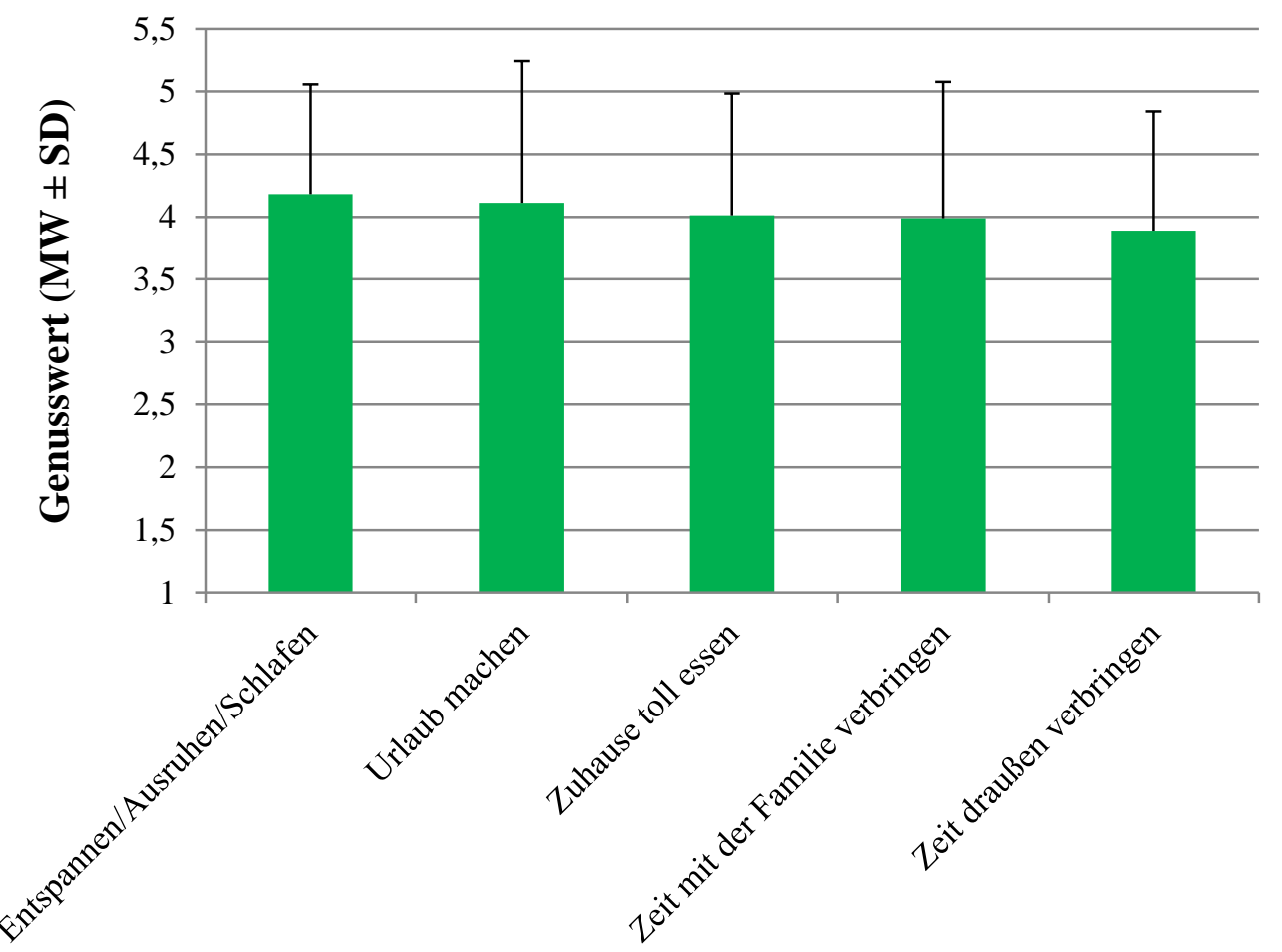

Bei Berechnung eines übergeordneten Scores für die fünf genussvollsten Verhaltensweisen der Deutschen (Abb. 1), weisen Personen mit Übergewicht/Adipositas niedrigere Genusswerte als Normalgewichtige auf (MW 3,28 vs. MW 3,44; siehe Abb. 2). Dieser Unterschied deutet einen Trend an, erreicht aber nicht Signifikanzniveau $(p=0,07)$. 
Abbildung 2: Verhaltensweisen mit dem höchsten Genussempfinden bei Personen mit Übergewicht/Adipositas im Vergleich zu Normalgewichtigen

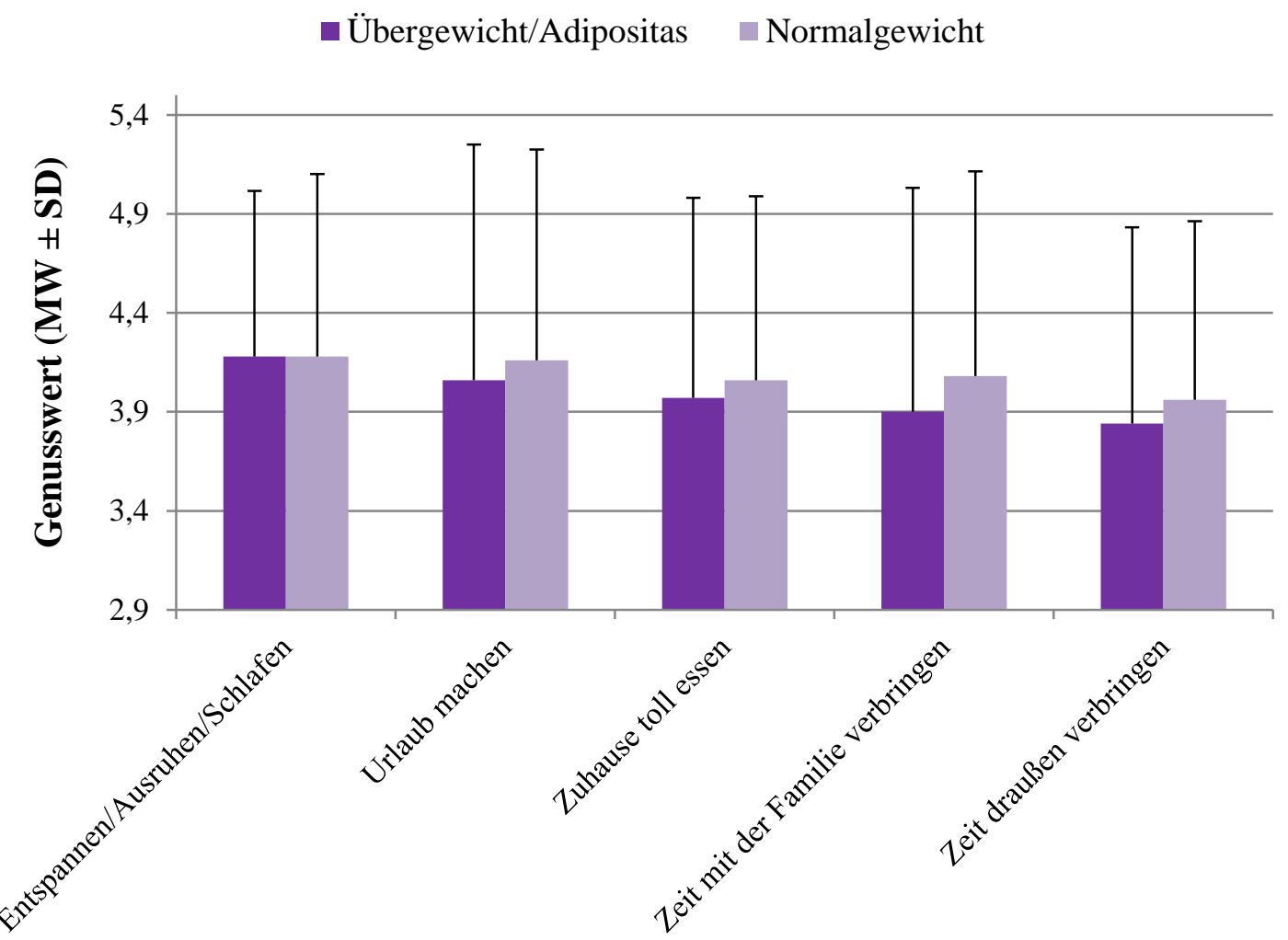

\section{Lebenszufriedenheit und Wohlbefinden}

Die allgemeine Lebenszufriedenheit wurde mittels der Deutschen Version der SWLS (16) gemessen. Hier zeigten sich signifikante Unterschiede zwischen Normalgewichtigen $(\mathrm{Mdn}=$ 24) und Personen mit Übergewicht/Adipositas (Mdn = 22) im Mann-Whitney-U-Test ( $\mathrm{z}=$ 3,125, $p<0,01$ ), wobei letztgenannte eine geringere Lebenszufriedenheit aufwiesen. Insgesamt zeigten sich ähnliche Werte in der Lebenszufriedenheit im Vergleich zur repräsentativen Validierungsstudie aus dem Jahr 2008 (16).

Das aktuelle, auf die letzten zwei Wochen bezogene Wohlbefinden wurde mittels des deutschsprachigen WHO-5-Fragebogens zum Wohlbefinden $(8 ; 2 ; 3)$ gemessen. Hier zeigten sich signifikante Unterschiede zwischen Normalgewichtigen $(\mathrm{Mdn}=15)$ und Personen mit Übergewicht/Adipositas (Mdn = 14) im Mann-Whitney-U-Test $(\mathrm{z}=-3,305, p=0,001)$, wobei Personen mit Übergewicht/Adipositas ein geringeres Wohlbefinden aufwiesen. WHO-5Scores kleiner 13 können auf Depressionen hinweisen. Ein Score kleiner 13 war bei 35,7 \% 
der Personen ohne Übergewicht/Adipositas und bei 42,8 \% der Personen mit Übergewicht/Adipositas zu finden.

\section{Wichtige Aspekte für genussvolles Essen}

Bei der offenen Frage, was für ein genussvolles Essen wichtig ist, dominieren in den Nennungen zwei Aspekte. Einmal geben mehr als ein Viertel der Deutschen „lecker, Geschmack, Genuss, Geruch“ an. Ähnlich häufig ist die Nennung von „Zeit, Ruhe, Entspannung“. Alle anderen Aspekte spielen eine deutlich geringere Rolle. Die geschmackliche Qualität wie auch die Situation, in der gegessen wird, spielen also für genussvolles Essen die entscheidende Rolle (siehe Abb. 3).

Abbildung 3: Offene Nennungen, die als wichtig für genussvolles Essen eingeschätzt wurden.

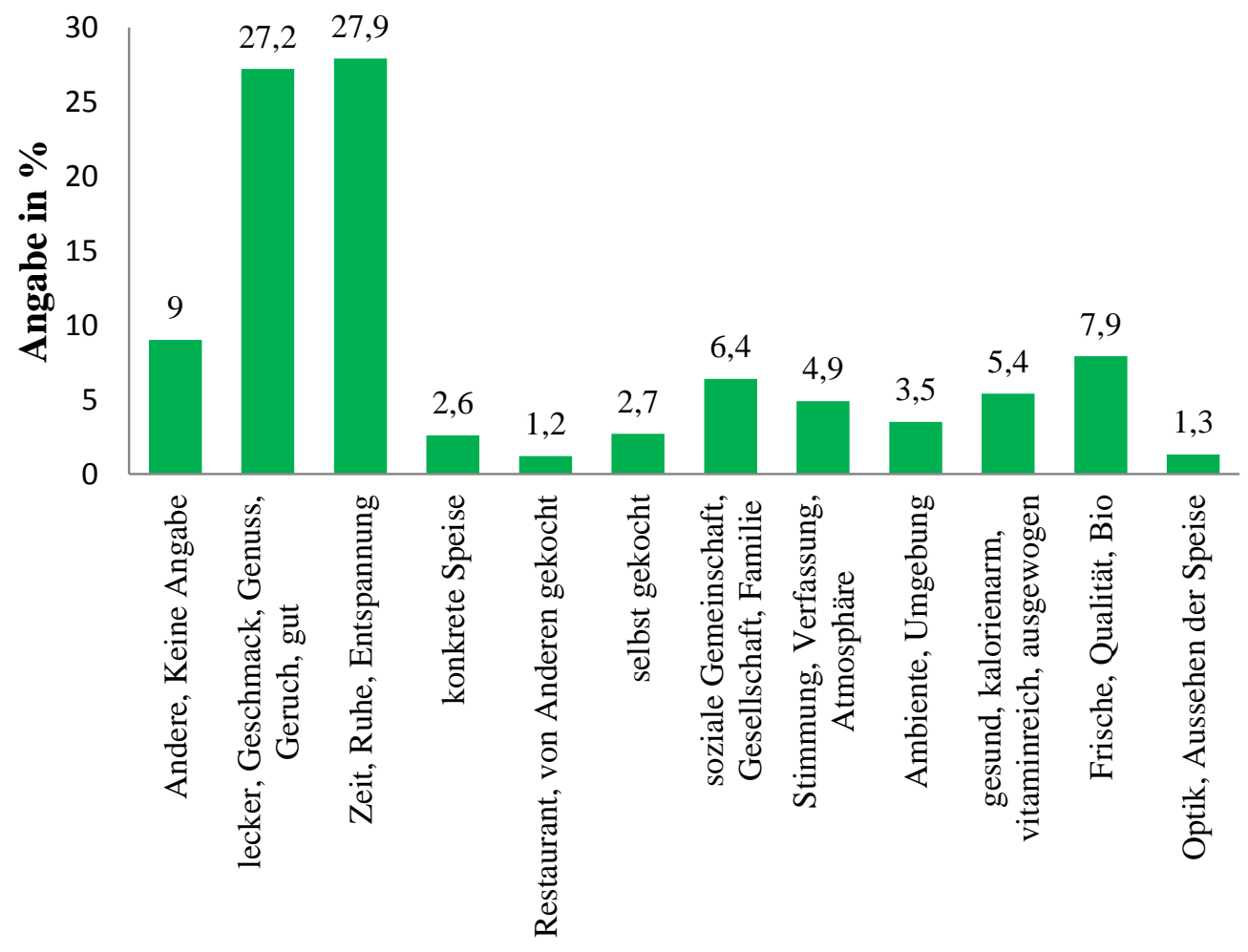

Personen mit Übergewicht/Adipositas unterscheiden sich in den benannten Aspekten nicht signifikant von Personen mit Normalgewicht. 


\section{Selbsteinschätzung als Genießer}

Insgesamt bezeichnen sich 80,1 \% der Deutschen als Genießer (Summe aus den drei Kategorien „wohl eher ein Genießer“, „ein Genießer“, „ein großer Genießer“; siehe Abb. 4). Es gibt keine signifikanten Unterschiede zwischen den vier BMI-Kategorien Untergewicht, Normalgewicht, Übergewicht und Adipositas bezüglich der Selbsteinschätzung als Genießer $\left(\chi^{2}(\mathrm{df}=3, \mathrm{~N}=1034)=1.44, p=.697\right)$.

Abbildung 4: Selbsteinschätzung der Deutschen als Genießer (6-stufige Skala)

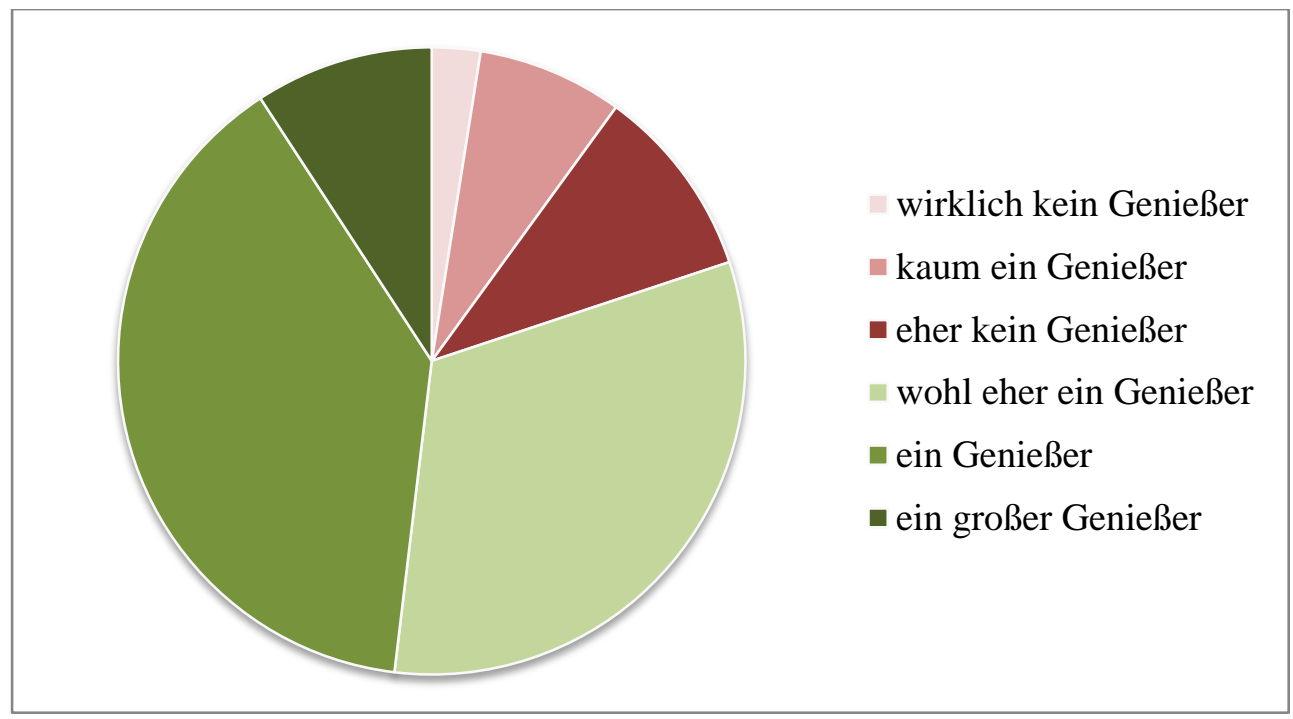

Gemessen mit der SWLS (16) zeigten sich signifikante Unterschiede in der Lebenszufriedenheit zwischen Genießern $(\mathrm{Mdn}=24)$ und Nicht-Genießern $(\mathrm{Mdn}=20)$ im Mann-Whitney-U-Test $(\mathrm{z}=-3,751, p<0,001)$, wobei letztgenannte eine geringere Lebenszufriedenheit aufwiesen. Gemessen mit dem WHO-5 (8) zeigten sich signifikante Unterschiede im Wohlbefinden zwischen Genießern (Mdn = 15) und Nicht-Genießern (Mdn = 13) im Mann-Whitney-U-Test $(\mathrm{z}=-3,094, p<0,01)$, wobei letztgenannte ein geringeres Wohlbefinden aufwiesen.

Die folgenden Ergebnisse zu essensbezogenen Verhaltensweisen beziehen sich auf vier bis sieben kategoriale Antwortmöglichkeiten der jeweiligen Fragen. Genießer haben, im Vergleich zu Nicht-Genießern, nach Selbsteinschätzung eine gesündere Ernährungsweise ( $\chi 2$ $(\mathrm{df}=3, N=1034)=46.74, p<.001)$, sind häufiger für das Kochen und den Einkauf zuständig $(\chi 2(\mathrm{df}=5, N=1034)=16.50, p<.01)$, können besser kochen $(\chi 2(\mathrm{df}=5, N=1034)=61.34, p$ 
$<.001)$, und Kochen macht ihnen mehr Spaß und wird seltener als lästige Pflicht angesehen $(\chi 2(\mathrm{df}=4, N=1034)=80.27, p<.001)($ alles nach Selbstauskunft $)$.

\section{$\underline{\text { Diskussion }}$}

Bei den besonders mit Genuss assoziierten Verhaltensweisen spielt Essen eine große Rolle. Es sind keine eindeutigen Unterschiede in der Genussfähigkeit beim Essen und in anderen Alltagsaktivitäten zwischen Menschen mit Übergewicht/Adipositas und Normalgewicht zu finden, jedoch ist tendenziell ein geringerer Genuss bei Personen mit Übergewicht/Adipositas zu erkennen wenn man einen Summenscore über die wichtigsten genussvollen Aktivitäten erstellt (Abb. 2). Gleichzeitig haben Übergewichtige/Adipöse ein geringeres derzeitiges Wohlbefinden (WHO-5) und sind weniger zufrieden mit ihrem Leben allgemein (SWLS). Es ist bekannt, dass Adipositas mit erhöhter Depressivität einher geht (25).

Nach Selbsteinschätzung sind die Deutschen unabhängig von ihrem Körpergewicht zu etwa $80 \%$ Genießer. Hier zeigten sich vergleichbare Werte zu österreichischen Daten (24). Gruber et al. fanden zudem, dass Genießer häufiger verzichten, um das Besondere des Genusses auf Dauer zu wahren. Genuss beim Essen, Wohlbefinden, Lebenszufriedenheit und Gesundheit sind augenscheinlich keine Widersprüche und Genuss beim Essen könnte zu Gesundheit beitragen (19).

Für Genuss beim Essen ist nicht nur die geschmackliche Qualität der Speise, sondern auch die Situation, etwaige gelernte positive Assoziationen, eine passende Atmosphäre und die soziale Gemeinschaft von großer Relevanz (19). Von diesen Einflussfaktoren korreliert - wenn überhaupt - einzig die geschmackliche Qualität mit dem Energiegehalt der Speise. Die anderen Einflussfaktoren Situation, Assoziationen, Atmosphäre und soziale Gemeinschaft sind vom Energiegehalt entkoppelt. Dies eröffnet interessante präventive und therapeutische Perspektiven. Aus diesem Grund könnte es zielführend sein, spezielle Trainingsprogramme zu Genuss und Achtsamkeit als weitere verhaltenstherapeutische Strategien in die S3-Leitlinie zur Prävention und Therapie der Adipositas (11) aufzunehmen. Potentielle Ansätze dazu liefert auch das Konzept des Mindful Eating/Achtsamkeit beim Essen (31). 


\section{$\underline{\text { Limitationen }}$}

Die vorliegende Stichprobe ist repräsentativ für Geschlecht, Alter, Herkunft und Schulabschluss in Deutschland, weist jedoch nur einen Anteil von 18,1\% an Personen mit $\mathrm{BMI}>30 \mathrm{~kg} / \mathrm{m}^{2}$ und nur einen Anteil von 3,1 \% an Personen mit morbider Adipositas auf. Die Daten sind nicht repräsentativ für Personen mit Adipositas. Konkretere Aussagen zu Personen mit Adipositas sind daher in zukünftigen Untersuchungen weiter zu erforschen. Zudem sind alle Angaben Selbstauskünfte aus einer Onlinebefragung, die mittels eines selbstentwickelten Fragebogens durchgeführt wurde. Hier ist die Trennschärfe des Fragebogens zur Abgrenzung der einzelnen Variablen noch mittels einer zukünftigen Erhebung zu überprüfen.

\section{$\underline{\text { Einverständniserklärung }}$}

Die Einverständniserklärung wurde von den Studienteilnehmern im Rahmen ihrer, auf freiwilliger Basis getätigten Anmeldung zum Panel Lightspeed Research gegeben.

\section{$\underline{\text { Interessenkonflikt }}$}

Die Kosten der repräsentativen Studie zum Thema Genuss wurden von Lieferando.de übernommen. Die Studiendaten wurden, ohne Einfluss des Sponsors, vom Institut für Ernährungspsychologie an der Georg-August-Universität Göttingen ausgewertet und zur Erstellung des vorliegenden Beitrages interpretiert. 


\section{Literaturverzeichnis}

1. Axel, Richard. „Scents and Sensibility: A Molecular Logic of Olfactory Perception (Nobel Lecture)“. Angewandte Chemie International Edition, Bd. 44, Nr. 38, September 2005, S. 6110-6127. CrossRef, doi:10.1002/anie.200501726.

2. Bech, Per. „Measuring the Dimension of Psychological General Well-Being by the WHO-5“. QoL Newsletter, Bd. 2004, Nr. 32, 2004, S. 15-16.

3. ---. „Measuring Well-Being Rather than the Absence of Distress Symptoms: A Comparison of the SF-36 Mental Health Subscale and the WHO-Five Well-Being Scale“. International Journal of Methods in Psychiatric Research, Bd. 12, Nr. 2, Juni 2003, S. 85-91. CrossRef, doi:10.1002/mpr.145.

4. Bergler, Reinhold, u. a. „Genuss - Eine Bedeutungsanalyse und Normanalyse“. Genuss und Gesundheit, Kölner Univ.-Verl, 2002, S. 39.

5. Bergler, Reinhold, und Tanja Hoff. Genuss und Gesundheit. Kölner Univ.-Verl, 2002.

6. Bibliographisches Institut GmbH. Genuss, der. 2017, http://www.duden.de/rechtschreibung/Genuss.

7. Birbaumer, Niels, und Robert F. Schmidt. Biologische Psychologie: mit 44 Tabellen. 7., Überarb. und erg. Aufl, Springer Medizin, 2010.

8. Brähler, Elmar, u. a. „Teststatistische Prüfung Und Normierung Der Deutschen Versionen Des EUROHIS-QOL Lebensqualität-Index Und Des WHO-5 Wohlbefindens-Index“. Diagnostica, Bd. 53, Nr. 2, April 2007, S. 83-96. CrossRef, doi:10.1026/0012-1924.53.2.83.

9. Bundesministerium. Deutschland, wie es isst - Der BMEL-Ernährungsreport 2016. BMEL, Dezember 2015.

10. Chandrashekar, Jayaram, u. a. „The receptors and cells for mammalian taste“. Nature, Bd. 444, Nr. 7117, November 2006, S. 288-294. CrossRef, doi:10.1038/nature05401. 
11. Deutsche Adipositas-Gesellschaft (DAG) e.V., u. a. Interdisziplinäre Leitlinie der Qualität S3 zur „Prävention und Therapie der Adipositas“. Version 2.0 (April 2014). Version 2.0, April 2014, www.awmf.org/leitlinien/detail/1l/050-001.html.

12. DGEintern. 10 Regeln der DGE aktualisiert. Presseinformation, Deutsche Gesellschaft für Ernährung e . V. (DGE), 29. August 2017.

13. Ditzen, Beate, u. a. „Effects of Social Support and Oxytocin on Psychological and Physiological Stress Responses during Marital Conflict". Frontiers in Neuroendocrinology, Bd. 27, Nr. 1, Mai 2006, S. 134. CrossRef, doi:10.1016/j.yfrne.2006.03.279.

14. forum. ernährung heute. Kulinarische Intelligenz - Genuss ist Lebensqualität. 2010, http://www.forum-ernaehrung.at/events/kulinarische-intelligenz-genuss-istlebensqualitaet/.

15. Fromme, Stephanie. Mit Genuss überzeugen. Nr. 3/17, 2017, S. 144.

16. Glaesmer, Heide, u. a. „The German Version of the Satisfaction With Life Scale (SWLS): Psychometric Properties, Validity, and Population-Based Norms“. European Journal of Psychological Assessment, Bd. 27, Nr. 2, Januar 2011, S. 127-132. CrossRef, doi:10.1027/1015-5759/a000058.

17. Grimm, Jacob, und Wilhelm Grimm. Deutsches Wörterbuch von Jacob Grimm und Wilhelm Grimm. Bd. 5 Sp. 3477, Trier Center for Digital Humanities / Kompetenzzentrum für elektronische Erschließungs- und Publikationsverfahren in den Geisteswissenschaften an der Universität Trier, 1998, http://woerterbuchnetz.de/cgibin/WBNetz/wbgui_py?sigle=DWB.

18. ---. Deutsches Wörterbuch von Jacob Grimm und Wilhelm Grimm. Bd. 5, Sp. 3518, Trier Center for Digital Humanities / Kompetenzzentrum für elektronische Erschließungs- und Publikationsverfahren in den Geisteswissenschaften an der 
Universität Trier, 1998, http://woerterbuchnetz.de/cgibin/WBNetz/wbgui_py?sigle=DWB.

19. Gruber, Marlies. „Salutogenetische Aspekte des kulinarischen Genießens“. Ernährung \&amp; Medizin, Bd. 26, Nr. 03, September 2011, S. 115-119. CrossRef, doi:10.1055/s-0031-1286126.

20. Haenel, H. „Ernährung - Gesundheit - Genuss“. Wissenschaftliche Zeitschrift der Humboldt-Universität zu Berlin. Reihe Medizin., 1990, S. 219-221.

21. Henning, W., u. a. „Ein psychologisches Wertorientierungskonzept und seine Umsetzung in ein empirisches Analyseverfahren“. Genuss und Gesundheit, Kölner Univ.-Verl, 2002, S. 59f.

22. Hodgson, Ray J., und John B. Greene. „,The Saliva Priming Effect, Eating Speed and the Measurement of Hunger“. Behaviour Research and Therapy, Bd. 18, Nr. 4, 1980, S. 243-247. CrossRef, doi:10.1016/0005-7967(80)90081-9.

23. Ikemoto, Satoshi. „Dopamine Reward Circuitry: Two Projection Systems from the Ventral Midbrain to the Nucleus Accumbens-olfactory Tubercle Complex“. Brain Research Reviews, Bd. 56, Nr. 1, November 2007, S. 27-78. CrossRef, doi:10.1016/j.brainresrev.2007.05.004.

24. Johnson, Katerina V. A., und Robin I. M. Dunbar. „Pain Tolerance Predicts Human Social Network Size“. Scientific Reports, Bd. 6, Nr. 1, Juli 2016. CrossRef, doi:10.1038/srep25267.

25. Luppino, Floriana S., u. a. „Overweight, Obesity, and Depression: A Systematic Review and Meta-Analysis of Longitudinal Studies“. Archives of General Psychiatry, Bd. 67, Nr. 3, März 2010, S. 220. CrossRef, doi:10.1001/archgenpsychiatry.2010.2.

26. Lutz, Rainer. „Exploration positiver Eigenschaften - ein Beitrag zum verhaltensdiagnostischen Interview." Verhaltenstherapie, Selbstregulation, Selbstmanagement: Frederick H. Kanfer zum 70. Geburtstag, herausgegeben von 
Hans S. Reinecker und Frederick H. Kanfer, Hogrefe, Verl. für Psychologie, 1996, S. 187.

27. ---. Genussfähigkeit Die „Kleine Schule des Genießens“-eine euthyme Interventionlehrt uns Selbstfürsorge. Nr. 1/2017, 2017, S. 10.

28. ---. „Was ist Genuss? Eine Standortbestimmung“. VFED Fachmagazin, Nr. 1. Auflage 2018, 2018, S. 24-28.

29. Lutz, Rainer, und Eva Koppenhöfer, Herausgeber. „Kleine Schule des Genießens“. Genuss und Geniessen: zur Psychologie des genussvollen Erlebens und Handelns, Beltz, 1983, S. 112-125.

30. Noelle-Neumann, E., und R. Köcher. „Allensbacher Jahrbuch der Demoskopie 19841992“. Genuss und Gesundheit, Kölner Univ.-Verl, 2002, S. 39.

31. Peitz, Diana, und Petra Warschburger. „Mindful Eating - Das Potenzial von Achtsamkeit in der Adipositasbehandlung nutzen“. Adipositas, Bd. 3|2017, Nr. 11, S. $137-184$.

32. Schweppe, Ronald. „Mit Achtsamkeit zum Wunschgewicht“. UGBforum, Bd. 1/14, 2014, S. 13-16.

33. World Health Organisation [WHO]. Basic Documents. Forty-Eighth Edition. World Health Organization, 2014.

\section{Korrespondenzadresse:}

Carolin Hauck, Humboldtallee 32, 37073 Göttingen, Telefon: 0551/398964, Mail: carolin.hauck@med.uni-goettingen.de,www.ernaehrungspsychologie.org 


\section{Übersicht Eingesetzte Fragebögen}

Yale Food Addiction Scale (YFAS) 2.0

Fragebogen zum Essverhalten (FEV) erweitert/+

Fragebogen zum allgemeinen Gesundheitszustand (SF-36)

Fragebogen zur Erfassung des Sportverhaltens von Ausdauersportlern (FESA)

Multidimensional Inventory of Perfectionism in Sport (MIPS)

Eating Disorder Diagnostic Scale (EDDS) German 
Anhang

Yale Food Addiction Scale (YFAS) 2.0 
YFAS 2.0 - Stand: Juni 2016

Name:

Datum:

Geschlecht: weiblich männlich

Alter:

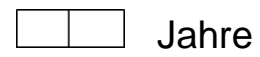

Wie groß sind Sie? \begin{tabular}{l|l|l|l}
\hline & & & \\
\end{tabular}

Wie viel wiegen Sie? \begin{tabular}{l|l|l|l}
\hline & & & \\
\hline
\end{tabular}

Bei dieser Befragung geht es um Ihre Essgewohnheiten innerhalb des letzten Jahres. Man hat manchmal Schwierigkeiten zu kontrollieren, wie viel man von bestimmten Nahrungsmitteln isst, beispielsweise:

- Süßwaren wie Eiscreme, Schokolade, Donuts und andere Backwaren, Kekse, Kuchen und andere Süßigkeiten

- Kohlenhydratreiche Nahrungsmittel wie Weißbrot, Brötchen, Nudeln und Reis

- Salzige Snacks wie Chips, Salzstangen und Cracker

- Fettreiche Nahrungsmittel wie Steak, Speck, Bratwurst, Hamburger, Döner, Pizza und Pommes Frites

- Zuckerhaltige Getränke wie Limonade, Cola, Fanta, Sprite und Energy Drinks

Wenn in den folgenden Fragen nach bestimmten Nahrungsmitteln gefragt wird, denken Sie bitte an irgendein Nahrungsmittel oder Getränk ähnlich wie in den oben aufgelisteten Gruppen von Nahrungsmitteln und Getränken oder denken Sie an irgendein anderes Nahrungsmittel, bei dem Sie im vergangenen Jahr Schwierigkeiten hatten dessen Konsum zu kontrollieren.

Bitte kreuzen Sie Zutreffendes an (bitte jeweils 1 Kreuz pro Zeile):

\begin{tabular}{|l|c|c|c|c|c|c|c|c|}
\hline IN DEN LETZEN 12 MONATEN: & Nie & $\begin{array}{l}\text { Seltener } \\
\text { als 1 } \\
\text { pro } \\
\text { Monat }\end{array}$ & $\begin{array}{l}1 \mathrm{x} \\
\text { pro } \\
\text { Monat }\end{array}$ & $\begin{array}{l}2-3 \mathrm{x} \\
\text { pro } \\
\text { Monat }\end{array}$ & $\begin{array}{l}1 \mathrm{x} \\
\text { pro } \\
\text { Woche }\end{array}$ & $\begin{array}{l}2-3 \times \\
\text { pro } \\
\text { Woche }\end{array}$ & $\begin{array}{l}4-6 \mathrm{x} \\
\text { pro } \\
\text { Woche }\end{array}$ & $\begin{array}{l}\text { Jeden } \\
\text { Tag }\end{array}$ \\
\hline A. Wie häufig treiben Sie Sport? & 1 & 2 & 3 & 4 & 5 & 6 & 7 & 8 \\
\hline $\begin{array}{l}\text { B. Wie häufig haben Sie Alltagsbewegungen, } \\
\text { wie Spazierengehen mit dem Hund oder } \\
\text { Fahrradfahren zur Arbeit, die mind. 30 } \\
\text { Minuten dauern? }\end{array}$ & 1 & 2 & 3 & 4 & 5 & 6 & 7 & 8 \\
\hline $\begin{array}{l}\text { 1. Wenn ich anfing bestimmte Nahrungsmittel } \\
\text { zu essen, aß ich viel mehr als geplant. }\end{array}$ & 1 & 2 & 3 & 4 & 5 & 6 & 7 & 8 \\
\hline $\begin{array}{l}\text { 2. Ich aß bestimmte Nahrungsmittel weiter, } \\
\text { obwohl ich nicht mehr hungrig war. }\end{array}$ & 1 & 2 & 3 & 4 & 5 & 6 & 7 & 8 \\
\hline $\begin{array}{l}\text { 3. Ich aß bis zu einem Punkt, an dem ich mich } \\
\text { körperlich schlecht fühlte. }\end{array}$ & 1 & 2 & 3 & 4 & 5 & 6 & 7 & 8 \\
\hline $\begin{array}{l}\text { 4. Ich machte mir viele Gedanken darüber, } \\
\text { den Konsum bestimmter Nahrungsmittel } \\
\text { einzuschränken, aber ich aß sie trotzdem. }\end{array}$ & 1 & 2 & 3 & 4 & 5 & 6 & 7 & 8 \\
\hline $\begin{array}{l}\text { 5. Ich verbrachte viel Zeit, in der ich mich } \\
\text { träge oder müde fühlte, weil ich mich } \\
\text { überessen hatte. }\end{array}$ & 1 & 2 & 3 & 4 & 5 & 6 & 7 & 8 \\
\hline
\end{tabular}




\begin{tabular}{|c|c|c|c|c|c|c|c|c|}
\hline IN DEN LETZEN 12 MONATEN: & $\mathrm{Nie}$ & $\begin{array}{l}\text { Seltener } \\
\text { als } 1 \mathrm{x} \\
\text { pro } \\
\text { Monat }\end{array}$ & $\begin{array}{c}1 \times \\
\text { pro } \\
\text { Monat }\end{array}$ & $\begin{array}{l}2-3 x \\
\text { pro } \\
\text { Monat }\end{array}$ & $\begin{array}{l}1 \times \\
\text { pro } \\
\text { Woche }\end{array}$ & $\begin{array}{l}2-3 x \\
\text { pro } \\
\text { Woche }\end{array}$ & $\begin{array}{l}4-6 x \\
\text { pro } \\
\text { Woche }\end{array}$ & $\begin{array}{c}\text { Jeden } \\
\text { Tag }\end{array}$ \\
\hline $\begin{array}{l}\text { 6. Ich verbrachte viel Zeit, in der ich } \\
\text { bestimmte Nahrungsmittel über den ganzen } \\
\text { Tag hinweg aß. }\end{array}$ & 1 & 2 & 3 & 4 & 5 & 6 & 7 & 8 \\
\hline $\begin{array}{l}\text { 7. Wenn bestimmte Nahrungsmittel nicht } \\
\text { vorhanden waren, scheute ich keine Mühen } \\
\text { diese zu bekommen. Zum Beispiel ging ich in } \\
\text { den Supermarkt um bestimmte } \\
\text { Nahrungsmittel zu kaufen, obwohl ich andere } \\
\text { Lebensmittel zuhause hatte. }\end{array}$ & 1 & 2 & 3 & 4 & 5 & 6 & 7 & 8 \\
\hline $\begin{array}{l}\text { 8. Ich aß bestimmte Nahrungsmittel so häufig } \\
\text { oder in solch großen Mengen, dass ich } \\
\text { aufhörte andere wichtige Dinge zu tun. Diese } \\
\text { Dinge konnten beispielsweise sein zu } \\
\text { arbeiten oder Zeit mit Familie oder Freunden } \\
\text { zu verbringen. }\end{array}$ & 1 & 2 & 3 & 4 & 5 & 6 & 7 & 8 \\
\hline $\begin{array}{l}\text { 9. Ich hatte Probleme mit meiner Familie oder } \\
\text { Freunden aufgrund der Häufigkeit meines } \\
\text { Überessens. }\end{array}$ & 1 & 2 & 3 & 4 & 5 & 6 & 7 & 8 \\
\hline $\begin{array}{l}\text { 10. Ich mied die Arbeit, Schule oder soziale } \\
\text { Aktivitäten, weil ich befürchtete mich dort zu } \\
\text { überessen. }\end{array}$ & 1 & 2 & 3 & 4 & 5 & 6 & 7 & 8 \\
\hline $\begin{array}{l}\text { 11. Wenn ich den Konsum bestimmter } \\
\text { Nahrungsmittel einschränkte oder ganz } \\
\text { aufhörte sie zu essen, fühlte ich mich gereizt, } \\
\text { nervös oder traurig. }\end{array}$ & 1 & 2 & 3 & 4 & 5 & 6 & 7 & 8 \\
\hline $\begin{array}{l}\text { 12. Wenn ich körperliche Symptome spürte, } \\
\text { weil ich bestimmte Nahrungsmittel nicht } \\
\text { gegessen hatte, aß ich diese Nahrungsmittel } \\
\text { um mich besser zu fühlen. }\end{array}$ & 1 & 2 & 3 & 4 & 5 & 6 & 7 & 8 \\
\hline $\begin{array}{l}\text { 13. Wenn ich emotionale Probleme hatte, weil } \\
\text { ich bestimmte Nahrungsmittel nicht gegessen } \\
\text { hatte, aß ich diese Nahrungsmittel um mich } \\
\text { besser zu fühlen. }\end{array}$ & 1 & 2 & 3 & 4 & 5 & 6 & 7 & 8 \\
\hline $\begin{array}{l}\text { 14. Wenn ich den Konsum bestimmter } \\
\text { Nahrungsmittel einschränkte oder ganz } \\
\text { aufhörte sie zu essen, verspürte ich } \\
\text { körperliche Symptome. Zum Beispiel hatte ich } \\
\text { Kopfschmerzen oder fühlte mich müde oder } \\
\text { schlapp. }\end{array}$ & 1 & 2 & 3 & 4 & 5 & 6 & 7 & 8 \\
\hline $\begin{array}{l}\text { 15. Wenn ich den Konsum bestimmter } \\
\text { Nahrungsmittel einschränkte oder ganz } \\
\text { aufhörte sie zu essen, verspürte ich ein } \\
\text { starkes Verlangen nach ihnen. }\end{array}$ & 1 & 2 & 3 & 4 & 5 & 6 & 7 & 8 \\
\hline $\begin{array}{l}\text { 16. Mein Essverhalten verursachte mir sehr } \\
\text { viel Leid. }\end{array}$ & 1 & 2 & 3 & 4 & 5 & 6 & 7 & 8 \\
\hline $\begin{array}{l}\text { 17. Ich hatte erhebliche Probleme in meinem } \\
\text { Leben aufgrund von Nahrung und Essen. } \\
\text { Diese Probleme betrafen beispielsweise } \\
\text { meinen Alltag, die Arbeit, die Schule, } \\
\text { Freunde, Familie oder meine Gesundheit. }\end{array}$ & 1 & 2 & 3 & 4 & 5 & 6 & 7 & 8 \\
\hline
\end{tabular}




\begin{tabular}{|c|c|c|c|c|c|c|c|c|}
\hline IN DEN LETZEN 12 MONATEN: & $\mathrm{Nie}$ & $\begin{array}{l}\text { Seltener } \\
\text { als } 1 x \\
\text { pro } \\
\text { Monat }\end{array}$ & $\begin{array}{l}1 \times \\
\text { pro } \\
\text { Monat }\end{array}$ & $\begin{array}{l}2-3 x \\
\text { pro } \\
\text { Monat }\end{array}$ & $\begin{array}{l}1 \times \\
\text { pro } \\
\text { Woche }\end{array}$ & $\begin{array}{l}2-3 x \\
\text { pro } \\
\text { Woche }\end{array}$ & $\begin{array}{l}4-6 x \\
\text { pro } \\
\text { Woche }\end{array}$ & $\begin{array}{c}\text { Jeden } \\
\text { Tag }\end{array}$ \\
\hline $\begin{array}{l}\text { 18. Ich hatte ein so schlechtes Gewissen } \\
\text { aufgrund des Überessens, dass ich andere } \\
\text { wichtige Dinge nicht tat. Diese Dinge konnten } \\
\text { beispielsweise sein zu arbeiten oder Zeit mit } \\
\text { Familie oder Freunden zu verbringen. }\end{array}$ & 1 & 2 & 3 & 4 & 5 & 6 & 7 & 8 \\
\hline $\begin{array}{l}\text { 19. Mein Überessen stand mir dabei im Weg } \\
\text { mich um meine Familie zu kümmern oder } \\
\text { meine häuslichen Pflichten zu erledigen. }\end{array}$ & 1 & 2 & 3 & 4 & 5 & 6 & 7 & 8 \\
\hline $\begin{array}{l}\text { 20. Ich mied die Arbeit, Schule oder soziale } \\
\text { Aktivitäten, weil ich bestimmte Nahrungsmittel } \\
\text { dort nicht essen konnte. }\end{array}$ & 1 & 2 & 3 & 4 & 5 & 6 & 7 & 8 \\
\hline $\begin{array}{l}\text { 21. Ich mied soziale Situationen, weil } \\
\text { Menschen es nicht akzeptiert hätten wie viel } \\
\text { ich gegessen hätte. }\end{array}$ & 1 & 2 & 3 & 4 & 5 & 6 & 7 & 8 \\
\hline $\begin{array}{l}\text { 22. Ich aß in derselben Art und Weise weiter, } \\
\text { obwohl mein Essverhalten emotionale } \\
\text { Probleme verursachte. }\end{array}$ & 1 & 2 & 3 & 4 & 5 & 6 & 7 & 8 \\
\hline $\begin{array}{l}\text { 23. Ich aß in derselben Art und Weise weiter, } \\
\text { obwohl mein Essverhalten körperliche } \\
\text { Probleme verursachte. }\end{array}$ & 1 & 2 & 3 & 4 & 5 & 6 & 7 & 8 \\
\hline $\begin{array}{l}\text { 24. Die gleiche Nahrungsmenge zu essen } \\
\text { brachte mir nicht den gleichen Genuss wie } \\
\text { früher. }\end{array}$ & 1 & 2 & 3 & 4 & 5 & 6 & 7 & 8 \\
\hline $\begin{array}{l}\text { 25. Ich wollte unbedingt den Konsum } \\
\text { bestimmter Nahrungsmittel einschränken oder } \\
\text { ganz auf sie verzichten, aber ich konnte es } \\
\text { einfach nicht. }\end{array}$ & 1 & 2 & 3 & 4 & 5 & 6 & 7 & 8 \\
\hline $\begin{array}{l}\text { 26. Ich musste immer mehr essen um die } \\
\text { Gefühle zu bekommen, die ich durch essen } \\
\text { erreichen wollte. Diese umfassten eine } \\
\text { Verminderung negativer Emotionen wie } \\
\text { Traurigkeit oder eine Erhöhung des } \\
\text { Wohlbefindens. }\end{array}$ & 1 & 2 & 3 & 4 & 5 & 6 & 7 & 8 \\
\hline $\begin{array}{l}\text { 27. Ich erbrachte keine gute Leistung auf der } \\
\text { Arbeit oder in der Schule, weil ich zu viel aß. }\end{array}$ & 1 & 2 & 3 & 4 & 5 & 6 & 7 & 8 \\
\hline $\begin{array}{l}\text { 28. Ich aß bestimmte Nahrungsmittel } \\
\text { weiterhin, obwohl ich wusste, dass es } \\
\text { körperlich gefährlich war. Zum Beispiel aß ich } \\
\text { weiterhin Süßigkeiten, obwohl ich Diabetes } \\
\text { hatte oder ich aß weiterhin fettreiche } \\
\text { Nahrungsmittel, obwohl ich eine } \\
\text { Herzerkrankung hatte. }\end{array}$ & 1 & 2 & 3 & 4 & 5 & 6 & 7 & 8 \\
\hline $\begin{array}{l}\text { 29. Ich hatte einen solch starken Drang } \\
\text { bestimmte Nahrungsmittel zu essen, dass ich } \\
\text { an nichts anderes mehr denken konnte. }\end{array}$ & 1 & 2 & 3 & 4 & 5 & 6 & 7 & 8 \\
\hline $\begin{array}{l}\text { 30. Ich hatte ein solch starkes Verlangen } \\
\text { nach bestimmten Nahrungsmitteln, dass ich } \\
\text { mich fühlte als müsste ich sie sofort essen. }\end{array}$ & 1 & 2 & 3 & 4 & 5 & 6 & 7 & 8 \\
\hline $\begin{array}{l}\text { 31. Ich versuchte den Konsum bestimmter } \\
\text { Nahrungsmittel einzuschränken oder ganz } \\
\text { aufzuhören sie zu essen, aber ich war } \\
\text { erfolglos. }\end{array}$ & 1 & 2 & 3 & 4 & 5 & 6 & 7 & 8 \\
\hline
\end{tabular}




\begin{tabular}{|l|c|c|c|c|c|c|c|c|}
\hline IN DEN LETZEN 12 MONATEN: & Nie & $\begin{array}{l}\text { Seltener } \\
\text { als 1 } \\
\text { pro } \\
\text { Monat }\end{array}$ & $\begin{array}{l}1 \mathrm{x} \\
\text { pro } \\
\text { Monat }\end{array}$ & $\begin{array}{l}2-3 \mathrm{x} \\
\text { pro } \\
\text { Monat }\end{array}$ & $\begin{array}{l}1 \mathrm{x} \\
\text { pro } \\
\text { Woche }\end{array}$ & $\begin{array}{l}2-3 \mathrm{x} \\
\text { pro } \\
\text { Woche }\end{array}$ & $\begin{array}{l}4-6 \mathrm{x} \\
\text { pro } \\
\text { Woche }\end{array}$ & $\begin{array}{l}\text { Jeden } \\
\text { Tag }\end{array}$ \\
\hline $\begin{array}{l}\text { 32. Ich versuchte und versagte dabei den } \\
\text { Konsum bestimmter Nahrungsmittel } \\
\text { einzuschränken oder ganz auf sie zu } \\
\text { verzichten. }\end{array}$ & 1 & 2 & 3 & 4 & 5 & 6 & 7 & 8 \\
\hline $\begin{array}{l}\text { 33. Ich war durch essen so abgelenkt, dass } \\
\text { ich mich hätte verletzen können (z. B. } \\
\text { während des Autofahrens, beim Überqueren } \\
\text { der Straße oder beim Bedienen von } \\
\text { Maschinen). }\end{array}$ & 1 & 2 & 3 & 4 & 5 & 6 & 7 & 8 \\
\hline $\begin{array}{l}\text { 34. Ich war durch Gedanken an Essen so } \\
\text { abgelenkt, dass ich mich hätte verletzten } \\
\text { können (z.B. während des Autofahrens, beim } \\
\begin{array}{l}\text { Überqueren der Straße oder beim Bedienen } \\
\text { von Maschinen). }\end{array}\end{array}$ & 1 & 2 & 3 & 4 & 5 & 6 & 7 & 8 \\
\hline $\begin{array}{l}\text { 35. Meine Freunde oder Familie machten sich } \\
\text { Sorgen darüber, wie häufig ich mich überaß. }\end{array}$ & 1 & 2 & 3 & 4 & 5 & 6 & 7 & 8 \\
\hline
\end{tabular}


Anhang

Fragebogen zum Essverhalten (FEV) erweitert/+ 


\section{Fragebogen zum Eßverhalten (FEV) von Volker Pudel und Joachim Westenhöfer}

Name:

Datum:

\section{Lesen Sie bitte die Aussagen genau durch und beantworten Sie bitte jede Frage sorgfältig und möglichst schnell. Lassen Sie keine Frage aus!}

1. Geschlecht: ....... weiblich

$\ldots \ldots \ldots \ldots$ männlich

2. Wie groß sind Sie?

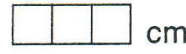

3. Wieviel wiegen Sie?

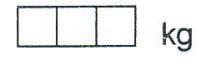

4. Welches war Ihr niedrigstes

(Erwachsenen-)Gewicht?

Das war vor $\square \square$ Jahren
Das war vor $\square$ Monaten

5. Welches war

Ihr höchstes Gewicht?

Das war vor

Das war vor

\begin{tabular}{|l|l|}
\hline & \\
\hline & \\
\hline
\end{tabular}

\begin{tabular}{r|r}
\hline \\
Jahren \\
Monaten
\end{tabular}

6. Welches ist Ihr Schulabschluß?

Hauptschule ohne Lehre ..... . 1

Hauptschule mit Lehre ......2 $\square$

Weiterführende Schule ...... . 3 $\square$

Abitur/Hochschule ..........4
7. Wie alt sind Sie? Jahre

8. Wie ist Ihre Lebenssituation?

Ich lebe allein .......... $\square$

Ich lebe mit Kind/Kindern .....2 $\square$

Ich lebe mit Partner . . . . . . . . 3 $\square$

Ich lebe mit Partner und

Kind/Kindern .........4 $\square$

Ich lebe bei den Eltern ......5 $\square$

Keine der angeführten . . . . . 6 $\square$

Für die Fragen 9 bis 44 bitte Zustimmung oder Ablehnung ankreuzen:

9. Ich kann mich bei einem ${ }^{\substack{\text { trifft trifft } \\ \text { nicht } \\ z u}}$ leckeren Duft nur schwer vom Essen zurückhalten, auch wenn ich vor kurzer Zeit erst gegessen habe.

10. Ich esse gewöhnlich zuviel, wenn ich in Gesellschaft bin, z. B. bei Festen und Einladungen ..................

11. Ich bin meistens so hungrig, daß ich öfter zwischen den Mahlzeiten esse ..........

12. Wenn ich die Kalorienmenge erreicht habe, die ich mir als Grenze gesetzt habe, gelingt es mir meistens, mit dem Essen aufzuhören ...........

13. Weil ich zu großen Appetit habe, fällt es mir schwer, eine Diät einzuhalten . . . . . . . . . .

14. Ich esse absichtlich kleine Portionen, um nicht zuzunehmen

15. Manchmal schmeckt es mir so gut, daß ich weiter esse, obwohl ich schon satt bin

16. Manchmal wünsche ich $\begin{aligned} & \text { trifft trifft } \\ & \text { zucht } \\ & \text { zu }\end{aligned}$
mir, daß mir ein Fachmann
sagt, ob ich satt bin oder noch
mehr essen darf ...........

17. Wenn ich ängstlich oder angespannt bin, fange ich oft an zu essen ..............

18. Das Leben ist zu kurz, um sich auch noch mit Diät herumzuschlagen .......

19. Ich habe schon mehr als einmal eine Schlankheitsdiät gemacht ..............

20. Oft habe ich ein so starkes Hungergefühl, daß ich einfach etwas essen muß ..........

21. Wenn ich mit jemandem zusammen bin, der kräftig ißt, esse ich meistens zuviel

22. Bei den üblichen Nahrungsmitteln kenne ich ungefähr den Kaloriengehalt . . . . .

23. Wenn ich mal mit dem Essen begonnen habe, kann ich manchmal nicht mehr aufhören
24. Mir fällt es nicht schwer zu nich 24. Mir fällt es nicht schwer, zu Essensreste einfach übrigzulassen.

25. Zu den üblichen Essenszeiten bekomme ich automatisch Hunger. . . . . . . . . . . .

26. Wenn ich während einer Diät „sündige“, dann halte ich mich anschließend beim Essen zurück, um wieder auszugleichen ..............

27. Wenn andere in meiner $\mathrm{Ge}$ genwart essen, möchte ich mitessen

28. Wenn ich Kummer habe, esse ich oft zuviel

29. Essen macht mir viel Spaß, und ich will es mir nicht durch Kalorienzählen oder Gewichtskontrollen verderben

30. Wenn ich leckere Dinge sehe, kriege ich häufig solchen Appetit, daß ich sie sofort esse 
$\begin{array}{ll}\text { trifft trifft } & z u \text { nicht }\end{array}$ 31. Häufig höre ich auf zu es- zu sen, obwohl ich noch gar nicht richtig satt bin.............

32. Mein Magen kommt mir oft wie ein „Faß ohne Boden" vor

33. In den letzten zehn Jahren hat sich mein Gewicht so gut wie nicht verändert.

$\square \square$

34. Da ich ständig Appetit habe, fällt es mir schwer, mit dem Essen aufzuhören, bevor der Teller leer ist

35. Wenn ich mich einsam füh. le, tröste ich mich mit Essen

36. Ich halte mich beim Essen bewußt zurück, um nicht zuzunehmen

37. Spätabends oder in der Nacht bekomme ich manchmal großen Hunger

38. Ich esse alles, was ich möchte und wann ich es will .

39. Ich esse eher langsam, ohne groß darüber nachzudenken ...........

40. Ich zähle Kalorien, um mein Gewicht unter Kontrolle zu halten

41. Bestimmte Nahrungsmittel meide ich, weil sie dick machen

42. Ich könnte zu jeder Tageszeit essen, da ich ständig Appetit habe..............

43. Ich achte sehr auf meine Figur...............

44. Wenn ich während einer Diät etwas „Unerlaubtes“ esse, dann denke ich oft „,Jetzt ist es auch egal", und dann lange ich erst recht zu ...........

$\square \square$

Bei den Fragen 45 bis 57 bitte ankreuzen, was am ehesten auf Sie zutrifft:

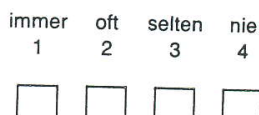

45. Haben Sie auch zwischen den Essenszeiten Hungergefühle

46. Wenn Sie zuviel gegessen haben, bringen Sie Gewissensbisse dazu, sich eher zurückzuhalten?

47. Wäre es schwierig für Sie, eine Mahlzeit mittendrin zu unterbrechen und dann vier Stunden lang nichts mehr zu essen? 48. Achten Sie darauf, daß Sie keinen Vorrat an verlockenden Lebensmitteln haben?.

49. Kaufen Sie häufig kalorienarme Lebensmittel?

50. Essen Sie kontrolliert, wenn Sie mit anderen zusammen sind, und lassen Sie sich dann gehen, wenn Sie allein sind?

51. Essen Sie bewußt langsam, um Ihre Nahrungsaufnahme einzuschränken?

52. Wie oft verzichten Sie auf Nachtisch, weil Sie keinen Appetit mehr haben?

53. Wie häufig kommt es vor, daß Sie bewußt weniger essen, als Sie gern möchten?

54. Kommt es vor, daß Sie Essen verschlingen, obwohl Sie nicht hungrig sind?

55. Trifft diese Aussage auf Ihr Eßverhalten zu?

„Morgens halte ich noch Diät, aber durch die Tagesereignisse bin ich am Abend so weit, daß ich wieder esse, was ich will. Ich nehme mir dann vor, ab morgen standhaft zu bleiben."

56. Würden Sie Ihre Lebensweise ändern, wenn Sie eine Gewichtsveränderung von fünf Pfund feststellten? ......... 57. Achten Sie darauf, was Sie essen?

58. Kreuzen Sie an, was auf Ihr EBverhalten zutrifft (nur eine Antwort):

Ich esse, was ich will, wann ich will ................

Ich esse gewöhnlich, was ich will, wann ich will ...........2

Ich esse oft, was ich will, wann ich will .............

Ich halte mich ebenso oft zurück wie ich nachgebe ........4 Ich halte mich gewöhnlich zurück gebe selten nach . .........5 Ich halte mich durchweg zurück, gebe nicht nach . . . . . . . . 6

Bei der Frage 60 bitte Zutreffendes ankreuzen. Es sind mehrere Angaben möglich. 60. Was bereitet Ihnen in Ihrem Eßverhalten die größten Schwierigkeiten? Verlangen nach Süßem Alkoholische Getränke

Essen in Gesellschaft Langeweile Streß
59. Wie häufig haben Sie bereits Schlankheitsdiäten gemacht?

$1-3$ mal ............. $\square$

$4-8 \mathrm{mal} . . . \ldots \ldots \ldots \ldots 2 \square$

9-15mal . . . . . . . . . . . . 3

Mehr als $15 \mathrm{mal} . \ldots \ldots \ldots \ldots 4 \square$ In regelmäßigen Abständen . . .5 $\square$ Ich halte so gut wie immer Diät $6 \square$ Noch nie .............7 $\square$ 


\section{Weitere Fragen zum Essverhalten}

Lesen Sie die Aussagen genau durch und beantworten Sie bitte jede Frage sorgfältig und möglichst schnell. Kreuzen Sie bitte bei jeder Frage an, was gegenwärtig auf Sie zutrifft. Wenn Sie sich nicht genau entscheiden können, dann kreuzen Sie das Feld an, das noch am ehesten auf Sie zutrifft. Aber lassen Sie bitte keine Frage aus. Auch dann, wenn manche Fragen sehr ähnlich sind. Vielen Dank!

$$
\begin{array}{ll}
\text { trifft } & \text { trifft } \\
\mathrm{zu} & \text { nicht } \\
& \mathrm{zu}
\end{array}
$$

1. Wenn ich an einem Tag etwas mehr esse, gleiche ich es am nächsten Tag wieder aus.

2. Ich esse Lebensmittel, die schlank machen, auch wenn sie mir nicht besonders schmecken.

3. Zum Abnehmen wäre mir eine Diät zu langweilig.

4. Obwohl ich sehr auf meine Figur achte, kann ich die Vielfalt der Lebensmittel genießen.

5. Ich lasse lieber eine Mahlzeit ausfallen, als nach der Hälfte aufzuhören.

6. Bei mir wechseln sich Phasen, in denen ich streng Diät halte mit Zeiten $a b$, bei denen ich esse, was und wieviel ich will.

7. Manchmal lasse ich Mahlzeiten ausfallen, um nicht zuzunehmen.

8. Es gibt Lebensmittel, die ich grundsätzlich nicht esse, obwohl ich sie mag.

9. Beim Abnehmen versuche ich mich möglichst an einen Plan zu halten.

10. Üblicherweise bevorzuge ich leichte Lebensmittel, die nicht dick machen.

11. Wenn ich bei einer Mahlzeit zuviel esse, esse ich bei der nächsten weniger.

12. Ohne Diätplan weiß ich gar nicht, wie ich mein Gewicht in den Griff bekommen kann.

13. Bei einer Diät zählt für mich der schnelle Erfolg.
14. Essen Sie bei Mahlzeiten bewußt weniger, als sie eigentlich möchten?

15. Wie häufig beschäftigen Sie Gedanken ans Essen, die im Zusammenhang mit Ihrem Gewicht stehen?

16. Haben Sie ein schlechtes Gewissen oder Schuldgefühle, wenn Sie zuviel gegessen haben?

17. Verwenden Sie zuviel Zeit und zu viele Gedanken für das Essen?

18. Was war Ihre bislang größte Gewichtsabnahme innerhalb eines Monats?

0 bis 2 Kilogramm

2,5 bis 4,5 Kilogramm

5 bis 7 Kilogramm

7,5 bis 9,5 Kilogramm

10 und mehr Kilogramm

19. Was war Ihre bislang größte Gewichtszunahme innerhalb einer Woche?

0 bis 0,5 Kilogramm

bis 1 Kilogramm

bis 1,5 Kilogramm

bis 2,5 Kilogramm

mehr als 2,5 Kilogramm

20. Um wieviel Kilogramm schwankt Ihr Gewicht normalerweise in einer Woche?

0 bis 0,5

0,6 bis 1

1,1 bis 1,5

1,6 bis 2,5

mehr als 2,5

21. Als Sie Ihr bislang höchstes Gewicht hatten, um wieviel Kilogramm lag das über Ihrem Wunschgewicht?

0 bis 0,5

0,6 bis 2,5

2,6 bis 5

5,1 bis 10

über 10 immer oft selten nie

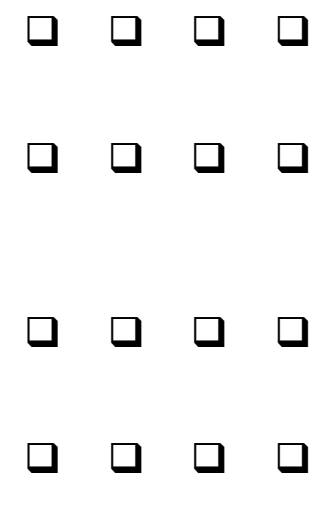

Noch 9 Fragen auf der nächsten Seite 


\section{Anhang}

22. Wie sehr hängt Ihr Selbstwertgefühl von Ihrer Figur ab?

wenig

mäßig

stark

sehr stark

23. Wenn Sie 3-5 kg zunehmen würden, würden Sie dann am ehesten ...

gelassen reagieren

sich Sorgen machen

sich deutliche Sorgen machen $\square$

Angst oder Panik bekommen

24. Ich habe Heißhungerattacken oder Essanfälle, während denen ich in kurzer Zeit sehr große Mengen esse.

Wenn ja:

a) Ich esse dabei Mengen, die deutlich größer sind als das, was die meisten Menschen unter ähnlichen Bedingungen essen würden.

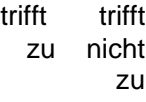

b) Ich esse dabei schneller als gewöhnlich.

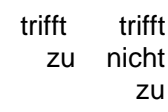

c) Ich esse so lange, bis ich mich unangenehm voll fühle.

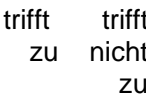

d) Ich esse in solchen Situationen allein - aus Verlegenheit und Scham über die Menge die ich esse.

e) Ich habe dabei das Gefühl, keine ausreichende Kontrolle darüber zu haben, was und wieviel ich esse. f) Ich esse viel, obwohl ich keinen körperlichen Hunger habe. $\begin{array}{cr}\text { trifft } & \text { trifft } \\ \text { zu } & \text { nicht }\end{array}$

$\square \quad$ zu

g) Danach fühle ich mich schuldig, deprimiert oder von mir selbst angeekelt.

$\begin{array}{rr}\text { trifft } & \text { trifft } \\ \text { zu } & \text { nicht } \\ & \text { zu } \\ \square & \square\end{array}$

25. Wie häufig haben Sie bereits gefastet, um abzunehmen oder nicht zuzunehmen?

1-3 mal

4-8 mal

mehr als 15 mal

in regelmäßigen Abständen

faste so gut wie immer

noch nie

26. Haben Sie in der letzten Zeit absichtlich sehr viel Sport oder Fitnesstraining gemacht, um abzunehmen oder nicht zuzunehmen?

ja, häufig

ja, öfters

ja, gelegentlich

ja, schon mal vorgekommen nein, noch nie

27. Haben Sie in der letzten Zeit nach dem Essen absichtlich erbrochen, um nicht zuzunehmen?

ja, häufig

ja, öfters

ja, gelegentlich

ja, schon mal vorgekommen nein, noch nie
29. Ich esse an den meisten Tagen einen Großteil des täglichen Essens erst nach 19 Uhr.

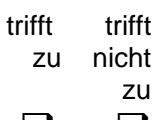

Wenn ja:

a) Ich schlafe nach dem reichhaltigen abendlichen Essen schlecht.

$\begin{array}{rr}\text { trifft } & \text { trifft } \\ \mathrm{zu} & \text { nicht } \\ & \mathrm{zu} \\ \square & \square\end{array}$

b) Ich bin am darauffolgenden Morgen meistens appetitlos und frühstücke nicht.

$\begin{array}{rr}\text { trifft } & \text { trifft } \\ \text { zu } & \text { nicht } \\ & \text { zu } \\ \square & \square\end{array}$

c) Es passiert mir häufiger, dass ich nachts aufstehe, um etwas zu essen.

$$
\begin{array}{cr}
\text { trifft } & \text { trifft } \\
\text { zu } & \text { nicht }
\end{array}
$$$$
\text { Zu }
$$

30. Was ist Ihr Wunschgewicht?

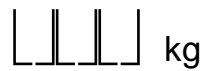

28. Haben Sie in der letzten Zeit ein oder mehrere der folgenden Mittel eingenommen, um abzunehmen oder nicht zuzunehmen?

Abführmittel

Entwässerungsmittel

Appetitzügler

Xenical/Reductil

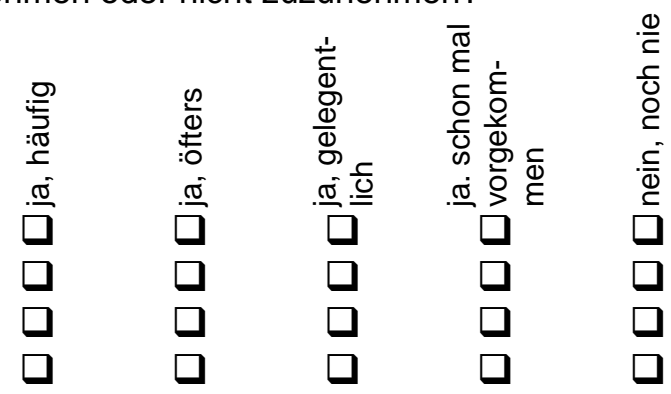


Anhang

Fragebogen zum allgemeinen Gesundheitszustand (SF-36) 
Geb. Datum:

\section{FRAGEBOGEN ZUM ALLGEMEINEN GESUNDHEITSZUSTAND}

In diesem Fragebogen geht es um die Beurteilung Ihres Gesundheitszustandes. Der Bogen ermöglicht es, im Zeitverlauf nachzuvollziehen, wie Sie sich fühlen und wie Sie im Alltag zurechtkommen.

Bitte beantworten Sie jede der grau unterlegten Fragen, indem Sie bei den Anwortmöglichkeiten die Zahl ankreuzen, die am besten auf Sie zutrifft.

\begin{tabular}{|c|c|c|c|c|c|}
\hline & $\begin{array}{l}\text { Ausge- } \\
\text { zeichnet }\end{array}$ & Sehr gut & Gut & $\begin{array}{l}\text { Weniger } \\
\text { gut }\end{array}$ & Schlecht \\
\hline $\begin{array}{l}\text { 1. Wie würden Sie Ihren Gesundheitszustand im } \\
\text { Allgemeinen beschreiben? }\end{array}$ & 1 & 2 & 3 & 4 & 5 \\
\hline
\end{tabular}

\begin{tabular}{|l|c|c|c|c|c|}
\hline 2. Im Vergleich zum vergangenen Jahr, wie & $\begin{array}{c}\text { Derzeit } \\
\text { viel } \\
\text { besser } \\
\begin{array}{l}\text { würden Sie Ihren derzeitigen } \\
\text { Gesundheitszustand beschreiben? }\end{array}\end{array}$ & $\begin{array}{c}\text { Derzeit } \\
\text { etwas } \\
\text { besser }\end{array}$ & $\begin{array}{c}\text { Etwa wie } \\
\text { vor einem } \\
\text { Jahr }\end{array}$ & $\begin{array}{c}\text { Derzeit } \\
\text { etwas } \\
\text { schlechter }\end{array}$ & $\begin{array}{c}\text { Derzeit } \\
\text { viel } \\
\text { schlechter } \\
5\end{array}$ \\
\hline
\end{tabular}

Im folgenden sind einige Tätigkeiten beschrieben, die Sie vielleicht an einem normalen Tag ausüben.

Sind Sie durch Ihren derzeitigen Gesundheitszustand bei diesen Tätigkeiten eingeschränkt? Wenn ja, wie stark?

3.a anstrengende Tätigkeiten, z.B. schnell laufen, schwere Gegenstände heben, anstrengenden Sport treiben

3.b mittelschwere Tätigkeiten, z.B. einen Tisch verschieben, staubsaugen, kegeln, Golf spielen

3.c Einkaufstaschen heben oder tragen

3.d mehrere Treppenabsätze steigen

3.e einen Treppenabsatz steigen

3.f sich beugen, knien, bücken

3.g mehr als 1 Kilometer zu Fuß gehen

3.h mehrere Straßenkreuzungen weit zu Fuß gehen

3.i eine Straßenkreuzung weit zu Fuß gehen

3.j sich baden oder anziehen

\begin{tabular}{|c|c|c|}
\hline $\begin{array}{l}\text { Ja, stark } \\
\text { eingeschränkt }\end{array}$ & $\begin{array}{c}\text { Ja, etwas } \\
\text { eingeschränkt }\end{array}$ & $\begin{array}{l}\text { Nein, überhaupt } \\
\text { nicht eingeschränkt }\end{array}$ \\
\hline 1 & 2 & 3 \\
\hline 1 & 2 & 3 \\
\hline 1 & 2 & 3 \\
\hline 1 & 2 & 3 \\
\hline 1 & 2 & 3 \\
\hline 1 & 2 & 3 \\
\hline 1 & 2 & 3 \\
\hline 1 & 2 & 3 \\
\hline 1 & 2 & 3 \\
\hline 1 & 2 & 3 \\
\hline
\end{tabular}


Hatten Sie in den vergangenen 4 Wochen aufgrund Ihrer körperlichen Gesundheit irgendwelche Schwierigkeiten bei der Arbeit oder anderen alltäglichen Tätigkeiten im Beruf bzw. zu Hause?

4.a Ich konnte nicht so lange wie üblich tätig sein

4.b Ich habe weniger geschafft als ich wollte

4.C Ich konnte nur bestimmte Dinge tun

4.d Ich hatte Schwierigkeiten bei der Ausführung (z.B. ich mußte mich besonders anstrengen)

\begin{tabular}{|c|c|}
\hline Ja & Nein \\
\hline 1 & \\
1 & 2 \\
1 & 2 \\
1 & 2 \\
\hline
\end{tabular}

Hatten Sie in den vergangenen 4Wochen aufgrund seelischer Probleme irgendwelche Schwierigkeiten bei der Arbeit oder anderen alltäglichen Tätigkeiten im Beruf bzw. zu Hause (z.B. weil Sie sich niedergeschlagen oder ängstlich fühlten)?

5.a Ich konnte nicht so lange wie üblich tätig sein

5.b Ich habe weniger geschafft als ich wollte

5.c Ich konnte nicht so sorgfältig wie üblich arbeiten

\begin{tabular}{|c|c|}
\hline Ja & Nein \\
& \\
1 & 2 \\
1 & 2 \\
1 & 2 \\
\hline
\end{tabular}

6. Wie sehr haben Ihre körperliche Gesundheit oder seelischen Probleme in den vergangenen 4 Wochen Ihre normalen Kontakte zu Familienangehörigen, Freunden, Nachbarn oder zum Bekanntenkreis beeinträchtigt?

\begin{tabular}{|c|c|c|c|c|}
$\begin{array}{c}\text { Überhaupt } \\
\text { nicht }\end{array}$ & Etwas & Mäßig & Ziemlich & Sehr \\
1 & 2 & 3 & 4 & 5 \\
\hline
\end{tabular}

7. Wie stark waren Ihre Schmerzen in den vergangenen 4 Wochen?

\begin{tabular}{|c|c|c|c|c|c|}
$\begin{array}{c}\text { Keine } \\
\text { Schmerzen }\end{array}$ & $\begin{array}{c}\text { Sehr } \\
\text { leicht }\end{array}$ & Leicht & Mäßig & Stark & $\begin{array}{c}\text { Sehr } \\
\text { stark }\end{array}$ \\
1 & 2 & 3 & 4 & 5 & 6 \\
\hline
\end{tabular}

8. Inwieweit haben die Schmerzen Sie in den vergangenen 4 Wochen bei der Ausübung Ihrer Alltagstätigkeiten zu Hause und im Beruf behindert?

\begin{tabular}{|c|c|c|c|c|}
$\begin{array}{c}\text { Überhaupt } \\
\text { nicht }\end{array}$ & $\begin{array}{c}\text { Ein } \\
\text { bißchen }\end{array}$ & Mäßig & Ziemlich & Sehr \\
1 & 2 & 3 & 4 & 5 \\
\hline
\end{tabular}

SF-36 German-Version 1.3

Copyright New England Medical Center Hospitals, Inc., 1992 


\begin{tabular}{|l|c|c|c|c|c|c|}
\hline $\begin{array}{l}\text { In diesen Fragen geht es darum, wie Sie sich } \\
\text { fühlen und wie es Ihnen in den vergangenen 4 } \\
\text { Wochen gegangen ist. (Bitte kreuzen Sie in jeder } \\
\begin{array}{l}\text { Zeile die Zahl an, die Ihrem Befinden am ehesten } \\
\text { entspricht). }\end{array}\end{array}$ & Immer & Meistens & $\begin{array}{c}\text { Ziemlich } \\
\text { oft }\end{array}$ & $\begin{array}{c}\text { Manch- } \\
\text { mal }\end{array}$ & Selten & Nie \\
9.a ... voller Schwung? & 1 & 2 & 3 & 4 & 5 & 6 \\
9.b ... sehr nervös? & 1 & 2 & 3 & 4 & 5 & 6 \\
9.c ... so niedergeschlagen, daß Sie nichts aufheitern \\
$\quad$ konnte?
\end{tabular}

\begin{tabular}{|l|c|c|c|c|c|}
\hline $\begin{array}{l}\text { 10. Wie häufig haben Ihre körperliche Gesundheit oder } \\
\text { seelischen Probleme in den vergangenen 4 Wochen } \\
\text { Ihre Kontakte zu anderen Menschen (Besuche bei } \\
\text { Freunden, Verwandten usw.) beeinträchtigt? }\end{array}$ & 1 & 2 & 3 & 4 & 5 \\
\hline
\end{tabular}

\begin{tabular}{|c|c|c|c|c|c|c|}
\hline \multicolumn{2}{|r|}{$\begin{array}{l}\text { Inwieweit trifft jede der folgenden Aussagen auf Sie } \\
\text { zu? }\end{array}$} & \multirow{2}{*}{$\begin{array}{c}\text { trifft ganz } \\
\text { zu } \\
1 \\
1\end{array}$} & \multirow{2}{*}{$\begin{array}{l}\text { trifft weit- } \\
\text { gehend } \\
\text { zu } \\
2\end{array}$} & \multirow{2}{*}{$\begin{array}{c}\text { weiß } \\
\text { nicht } \\
3\end{array}$} & \multirow{2}{*}{$\begin{array}{c}\text { trifft weit- } \\
\text { gehend } \\
\text { nicht zu } \\
4\end{array}$} & \multirow{2}{*}{$\begin{array}{c}\text { trifft } \\
\text { über- } \\
\text { haupt } \\
\text { nicht zu } \\
5\end{array}$} \\
\hline 11.a & $\begin{array}{l}\text { Ich scheine etwas leichter als andere krank zu } \\
\text { werden }\end{array}$ & & & & & \\
\hline 11.b & $\begin{array}{l}\text { Ich bin genauso gesund wie alle anderen, die ich } \\
\text { kenne }\end{array}$ & 1 & 2 & 3 & 4 & 5 \\
\hline 11.c & Ich erwarte, daß meine Gesundheit nachläßt & 1 & 2 & 3 & 4 & 5 \\
\hline 11.d & Ich erfreue mich ausgezeichneter Gesundheit & 1 & 2 & 3 & 4 & 5 \\
\hline
\end{tabular}

Besten Dank für Ihre Mühe.

SF-36 German-Version 1.3

Copyright New England Medical Center Hospitals, Inc., 1992 
Fragebogen zur Erfassung des Sportverhaltens von Ausdauersportlern (FESA) 


\section{Anhang 2. Fragebogen zur Erfassung des Sportverhaltens von Ausdauersportlern}

Wir würden gerne wissen, wie viel Sport sie treiben und wie wichtig er Innen ist. Bitte betrachten Sie Sport als jegliche geregelte Aktivität, die Ihre Herzfrequenz erhöht, wie z.B. Schwimmen, Radfahren, Laufen, Aerobik, Hanteltraining usw. und vervollständigen Sie den folgenden den Satz:

Ich treibe Stunden pro Woche Sport.

In diesem Fragebogen gibt es keine richtigen oder falschen Antworten. Es geht vielmehr darum, ob eine Aussage auf Sie zutrifft oder nicht. Jeder wird diese Fragen deshalb anders beantworten, und zwar so, wie es auf inn ganz persönlich passt. Im Nachfolgenden finden Sie eine Serie von Aussagen, die von Personen geäußert wurden, um ihre Einstellung zu Sport zu beschreiben. Sie sollen jedes Mal entscheiden, inwieweit dieser Satz auf Sie zutrifft, indem Sie die passende Nummer, die Ihre Einstellung gegenüber Ihrer sportlichen Aktivität in den letzten 3 Monaten am besten beschreibt, in der jeweiligen Skala ankreuzen.

Bitte überlegen Sie nicht lange, sondern geben Sie die erste spontane Antwort, die Ihnen in den Sinn kommt!

Benutzen Sie bitte die folgende Skala:

Trifft überhaupt

nicht zu
Trifft immer

zu 
Anhang 2. Fragebogen zur Erfassung des Sportverhaltens von Ausdauersportlern

1) Durch die Menge Sport, die ich treibe, bin ich am Arbeitsplatz erschöpft. (EDQ-1)

2) Nach einer Sporteinheit freue ich mich über das Leben. (EDQ-2)

3) Wenn ich die Wahl zwischen einer sportlichen Einheit und einem Familienfest habe, wähle ich lieber die sportliche Einheit. (EDS21-5)

4) Ich bin gereizt, wenn ich keinen Sport machen kann.(EDQ-3, EDS21-1)

5) Ich verbringe viel Zeit mit Sporttreiben. (EDS21-6)

6) Der Rest meines Lebens richtet sich nach dem Sport. (EDQ-4, EDS21-13+20)

7) Nach einer Sporteinheit bin ich sorgenfreier. (EDQ-5)

8) Ich treibe Sport um attraktiv zu sein. (EDQ-6)

9) Manchmal fehle ich am Arbeitsplatz um zu trainieren. (EDQ-7)

10) Nach einer Sporteinheit fühle ich mich in mir selbst wohler. (EDQ-8)

11) Ich werde unruhig, wenn ich mich nicht sportlich betätigen kann. (EDQ-9)

12) Ich steigere kontinuierlich meine sportlichen Umfänge, um die gewünschte Wirkung zu erzielen. (EDS21-10)
Trifft überhaupt

nicht zu

$1 \quad 2 \quad 3$

1

3

3

4

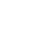

5

Trifft immer

$\mathrm{zu}$

7

7

$\begin{array}{lllllll}1 & 2 & 3 & 4 & 5 & 6 & 7\end{array}$

$\begin{array}{lllllll}1 & 2 & 3 & 4 & 5 & 6 & 7\end{array}$

$\begin{array}{lllllll}1 & 2 & 3 & 4 & 5 & 6 & 7\end{array}$

$\begin{array}{lllllll}1 & 2 & 3 & 4 & 5 & 6 & 7\end{array}$

$\begin{array}{lllllll}1 & 2 & 3 & 4 & 5 & 6 & 7\end{array}$

$\begin{array}{lllllll}1 & 2 & 3 & 4 & 5 & 6 & 7\end{array}$

$\begin{array}{lllllll}1 & 2 & 3 & 4 & 5 & 6 & 7\end{array}$

$\begin{array}{lllllll}1 & 2 & 3 & 4 & 5 & 6 & 7\end{array}$

$\begin{array}{lllllll}1 & 2 & 3 & 4 & 5 & 6 & 7\end{array}$ 


\section{Anhang 2. Fragebogen zur Erfassung des Sportverhaltens von Ausdauersportlern}

13) Um andere Menschen zu treffen treibe ich Sport. (EDQ-10)

14) Ich hasse es nicht in der Lage zu sein, Sport zu treiben. (EDQ11)

15) Ich treibe Sport um Langeweile zu vermeiden. (EDQ-12)

16) Wenn ich keinen Sport treiben kann, fühle ich mich dem Leben nicht gewachsen.(EDQ-13)

17) Ich treibe Sport um mich von aufkommender Anspannung/ Gereiztheit zu befreien. (EDS21-15)

18) Ich habe wenig Energie für meine(n) Partner/in, Familie und Freunde. (EDQ-15)

19) Ich fühle mich meiner Familie gegenüber schuldig wegen der Menge an Sport, die ich treibe. (EDQ-17)

20) Ich treibe länger Sport als ich beabsichtige. (EDS21-7)

21) Ich treibe Sport um gesünder zu sein.(EDQ-18)

22). Ich kann die Dauer meiner sportlichen Aktivität ohne Probleme selbst bestimmen.(EDS21-17)

23) Die Menge an Sport, die ich treibe, ist zu einem Problem geworden. (EDQ-20)

\begin{tabular}{|c|c|c|c|c|c|c|}
\hline \multicolumn{3}{|c|}{$\begin{array}{l}\text { Trifft überhaupt } \\
\text { nicht zu }\end{array}$} & & & & $\begin{array}{l}\text { Trifft immer } \\
\text { zu }\end{array}$ \\
\hline 1 & 2 & 3 & 4 & 5 & 6 & 7 \\
\hline 1 & 2 & 3 & 4 & 5 & 6 & 7 \\
\hline 1 & 2 & 3 & 4 & 5 & 6 & 7 \\
\hline 1 & 2 & 3 & 4 & 5 & 6 & 7 \\
\hline 1 & 2 & 3 & 4 & 5 & 6 & 7 \\
\hline 1 & 2 & 3 & 4 & 5 & 6 & 7 \\
\hline 1 & 2 & 3 & 4 & 5 & 6 & 7 \\
\hline 1 & 2 & 3 & 4 & 5 & 6 & 7 \\
\hline 1 & 2 & 3 & 4 & 5 & 6 & 7 \\
\hline 1 & 2 & 3 & 4 & 5 & 6 & 7 \\
\hline 1 & 2 & 3 & 4 & 5 & 6 & 7 \\
\hline
\end{tabular}


Anhang 2. Fragebogen zur Erfassung des Sportverhaltens von Ausdauersportlern

24) Ich halte mich immer genau an den Trainingsplan/die von mir vorgenommene Intensität und Umfang (zusammengenommen aus EDS21-11,18;EDQ-21,

25) Ich treibe Sport, auch wenn mir der Arzt davon abrät (EDS$2,9,16)$

26) Ich treibe jede Woche den gleichen Umfang an Sport. (EDQ$22,24)$

27) Nach einer Sporteinheit bin ich mit mir und der Welt zufrieden. (EDQ-23)

28) Meine Sportumfänge kollidieren mit meinem Sozialleben. (EDQ25)

29) Ich treibe Sport um mich fit zu fühlen. (EDQ-26)

30) Ich treibe Sport um Herzerkrankungen und anderen Krankheiten vorzubeugen. (EDQ-27)

31) Ich vermisse meine Freunde/Vereinskollegen, wenn ich keinen Sport machen kann (EDQ-28)

\section{Abschließend hätten wir noch ein paar Fragen zu Ihrer Person:}

Alter: Jahre

Geschlecht: $(\mathrm{m} / \mathrm{w})$

Seit wie vielen Jahren betreiben Sie Ausdauersport? Jahre

Ihre bevorzugte Distanz:

Nehmen Sie an Wettkämpfen teil? (ja/Nein)

\begin{tabular}{|c|c|c|c|c|c|}
\hline 1 & 2 & 3 & 4 & 5 & 6 \\
\hline 1 & 2 & 3 & 4 & 5 & 6 \\
\hline 1 & 2 & 3 & 4 & 5 & 6 \\
\hline 1 & 2 & 3 & 4 & 5 & 6 \\
\hline 1 & 2 & 3 & 4 & 5 & 6 \\
\hline 1 & 2 & 3 & 4 & 5 & 6 \\
\hline 1 & 2 & 3 & 4 & 5 & 6 \\
\hline 1 & 2 & 3 & 4 & 5 & 6 \\
\hline
\end{tabular}

Wie wichtig ist Ihnen die Ausübung ihres Sports verglichen mit anderen Tätigkeiten in ihrem Leben?

total

das

unwichtig

Wichtigste in

meinem Leben

$\begin{array}{llllllllll}1 & 2 & 3 & 4 & 5 & 6 & 7 & 8 & 9 & 10\end{array}$ 
Anhang

Multidimensional Inventory of Perfectionism in Sport (MIPS) 


\section{MIPS - Training}

\begin{tabular}{|l|l|l|l|l|l|l|}
\hline Frage & Nie & & & & & Immer \\
\hline $\begin{array}{l}\text { 1 Nach dem Training bin ich enttäuscht, wenn ich } \\
\text { nicht perfekte Leistungen gezeigt habe. }\end{array}$ & 1 & 2 & 3 & 4 & 5 & 6 \\
\hline $\begin{array}{l}2 \text { Im Training strebe ich danach so perfekt wie } \\
\text { möglich zu sein. }\end{array}$ & 1 & 2 & 3 & 4 & 5 & 6 \\
\hline $\begin{array}{l}\text { 3 Im Training ärgere ich mich maßlos wenn ich } \\
\text { Fehler mache }\end{array}$ & 1 & 2 & 3 & 4 & 5 & 6 \\
\hline $\begin{array}{l}4 \text { Im Training möchte ich alles perfekt machen. } \\
\text { 5 Wenn im Training eine Sache nicht perfekt }\end{array}$ & 1 & 2 & 3 & 4 & 5 & 6 \\
\hline läuft, dann bin ich mit dem gesamten & 3 & 4 & 5 & 6 \\
\hline $\begin{array}{l}\text { Training unzufrieden. } \\
\text { 6 Im Training bin ich perfektionistisch, was meine } \\
\text { Zielsetzungen angeht. }\end{array}$ & 1 & 2 & 3 & 4 & 5 & 6 \\
\hline $\begin{array}{l}7 \text { Im Training bin ich frustriert, wenn ich meine } \\
\text { extrem hohen Erwartungen nicht erfülle. }\end{array}$ & 1 & 2 & 3 & 4 & 5 & 6 \\
\hline $\begin{array}{l}\text { 8 Im Training habe ich das Bedürfnis perfekt zu } \\
\text { sein. }\end{array}$ & 1 & 2 & 3 & 4 & 5 & 6 \\
\hline $\begin{array}{l}\text { 9 Im Training fühle ich mich extrem gestresst } \\
\text { wenn nicht alles perfekt läuft. }\end{array}$ & 1 & 2 & 3 & 4 & 5 & 6 \\
\hline $\begin{array}{l}10 \text { Im Training habe ich den Wunsch, alles } \\
\text { perfekt zu machen. }\end{array}$ & 1 & 2 & 3 & 4 & 5 & 6 \\
\hline
\end{tabular}


Anhang

Eating Disorder Diagnostic Scale (EDDS) German 


\section{Beantworten Sie bitte sorgfältig alle Fragen. Wenn eine Frage nicht zutreffend ist, wählen Sie bitte NEIN oder 0 aus.}

\section{Während der letzten drei Monate...}

1. Haben Sie sich dick gefühlt?.

1

2. Hatten Sie ausgesprochene Angst an Gewicht zuzunehmen oder dick zu werden?

3. Hat Ihr Gewicht oder Ihre Figur beeinflusst wie Sie über sich selbst als Person urteilen?...

0

4. Gab es in den letzten drei Monaten Zeiten, in denen Sie eine Nahrungsmenge gegessen haben, die andere Menschen unter den gegebenen Umständen als ungewöhnlich groß ansehen würden (z.B. 500ml Eiscreme)? JA NEIN

5. Haben Sie, wenn Sie eine ungewöhnlich große Nahrungsmenge gegessen haben, das Gefühl von Kontrollverlust erlebt (z.B. nicht mit dem Essen aufhören zu können oder kontrollieren zu können, was oder wie viel Sie essen)? JA NEIN

6. Wie viele Male haben Sie durchschnittlich pro Monat in den letzten drei Monaten eine ungewöhnlich große Nahrungsmenge gegessen und das Gefühl von Kontrollverlust erlebt?...... $\begin{array}{lllllllllllllllll}0 & 1 & 2 & 3 & 4 & 5 & 6 & 7 & 8 & 9 & 10 & 11 & 12 & 13 & 14 & 15 & \geq 16\end{array}$

\section{Wenn Sie sich überessen und dabei einen Kontrollverlust erlebt haben, haben Sie...}

7. viel schneller gegessen als normalerweise?....... NEIN

8. gegessen bis Sie sich unangenehm voll gefühlt haben?... NEIN

9. große Nahrungsmengen gegessen, obwohl Sie nicht hungrig waren?..... NEIN

10. alleine gegessen, weil Sie sich dafür geschämt haben wie viel Sie aßen? NEIN

11. sich nach dem Überessen vor sich selbst geekelt, sich niedergeschlagen oder sehr schuldig gefühlt?..........JA NEIN

12. Beunruhigt es Sie sehr, wenn Sie sich unkontrolliert überessen?.... JA NEIN 
Um eine Gewichtszunahme zu verhindern oder den Folgen des Essens entgegenzuwirken, wie viele Male haben Sie durchschnittlich pro Monat in den letzten drei Monaten...

13. sich erbrochen?. 0 $\begin{array}{lllllllllllllll}2 & 3 & 4 & 5 & 6 & 7 & 8 & 9 & 10 & 11 & 12 & 13 & 14 & 15 & \geq 16\end{array}$

14. Abführmittel (Laxanzien) oder harntreibende Mittel (Diuretika) genutzt? 0 $\begin{array}{lllllllllllllll}2 & 3 & 4 & 5 & 6 & 7 & 8 & 9 & 10 & 11 & 12 & 13 & 14 & 15 & \geq 16\end{array}$

15. gefastet (mindestens zwei Mahlzeiten hintereinander ausgelassen)? 0 $\begin{array}{llllllllllllllll}1 & 2 & 3 & 4 & 5 & 6 & 7 & 8 & 9 & 10 & 11 & 12 & 13 & 14 & 15 & \geq 16\end{array}$

16. vermehrt Sport getrieben, um gezielt den Effekten des Überessens entgegenzuwirken? 0 2 45 78 $\begin{array}{lllllll}10 & 11 & 12 & 13 & 14 & 15 & \geq 16\end{array}$

17. Wie viele Male haben Sie durchschnittlich pro Monat in den letzten drei Monaten gegessen, nachdem Sie nachts aus dem Schlaf aufgewacht sind oder haben eine ungewöhnlich große Nahrungsmenge nach dem Abendessen gegessen und litten unter diesem nächtlichen Essen? $\begin{array}{llllllllll}0 & 1 & 2 & 3 & 4 & 5 & 6 & 7 & 8\end{array}$ $10 \quad 11 \quad 12 \quad 13 \quad 14 \quad 15 \geq 16$

18. Wie sehr beeinflussen Probleme mit Essen oder mit Ihrem Körperbild Ihre Beziehungen zu

Freunden und Familie, Ihre Arbeitsleistung oder Ihre Schulleistung?. überhaupt nicht etwas mäßig extrem

19. Wie viel wiegen Sie? Wenn Sie sich nicht sicher sind, schätzen Sie bitte.... $\mathrm{kg}$

20. Wie groß sind Sie?. $\mathrm{cm}$

21. Was war bei Ihrer momentanen Körpergröße das höchste Gewicht, das Sie jemals hatten?.. $\mathrm{kg}$

22. Was für ein Geschlecht haben Sie? MÄNNLICH WEIBLICH 23. Wie alt sind Sie? Jahre 
Anhang

Übersicht Aufbau der Studien

Repräsentativstichprobe

Klinische Stichprobe

Sportlerstichprobe

Genussstudie 
Anhang

Repräsentativstichprobe 


\section{Studie YFAS 2}

Base size: 1.000 net

Quotas to be achieved

\begin{tabular}{|c|c|c|}
\hline Gender & $\%$ & \\
\hline Male & 51 & \\
\hline Female & 49 & \\
\hline \multicolumn{3}{|l|}{ Age } \\
\hline $18-29$ & 23 & \\
\hline $30-39$ & 19 & \\
\hline $40-49$ & 27 & \\
\hline $50-65$ & 31 & \\
\hline \multicolumn{3}{|l|}{ Region } \\
\hline Schleswig-Holstein & 3 & \\
\hline Hamburg & 2 & \\
\hline Niedersachsen & 10 & \\
\hline Bremen & 1 & \\
\hline Nordrhein-Westfalen & 22 & \\
\hline Hessen & 8 & \\
\hline Rheinland-Pfalz & 5 & \\
\hline Baden-Württemberg & 13 & \\
\hline Bayern & 15 & \\
\hline Saarland & 1 & \\
\hline Berlin & 4 & \\
\hline Brandenburg & 3 & \\
\hline Mecklenburg-Vorpommern & 2 & \\
\hline Sachsen & 5 & \\
\hline Sachsen-Anhalt & 3 & \\
\hline Thüringen & 3 & \\
\hline Education & & D5 \\
\hline low/ medium & 68 & $1-3$ \\
\hline high/ higher (Abitur and higher) & 32 & 4,5 \\
\hline \multicolumn{3}{|l|}{ City size } \\
\hline up to 20,000 & 41 & \multirow{3}{*}{$\begin{array}{c}\text { Based } \\
\text { on } \\
\text { postal } \\
\text { code in } \\
\text { D3a }\end{array}$} \\
\hline $20,000-100,000$ & 27 & \\
\hline more than 100,000 & 32 & \\
\hline
\end{tabular}




\section{Fragebogen}

D1.

Sind Sie...?

Männlich

Weiblich

D2.

Und wie alt sind Sie?

Jahre

\begin{tabular}{|l|c|}
\hline Younger than 18 years & Close interview \\
\hline $18-29$ & \\
\hline $30-39$ & \\
\hline $40-49$ & \\
\hline $50-65$ & Close interview \\
\hline 66 years and older & \\
\hline
\end{tabular}

D3.

In welchem Bundesland leben Sie?

\begin{tabular}{|l|}
\hline Schleswig-Holstein \\
\hline Hamburg \\
\hline Niedersachsen \\
\hline Bremen \\
\hline Nordrhein-Westfalen \\
\hline Hessen \\
\hline Rheinland-Pfalz \\
\hline Baden-Württemberg \\
\hline Bayern \\
\hline Saarland \\
\hline Berlin \\
\hline Brandenburg \\
\hline Mecklenburg-Vorpommern \\
\hline Sachsen \\
\hline Sachsen-Anhalt \\
\hline Thüringen \\
\hline
\end{tabular}

D4.

Bitte geben Sie uns Ihre Postleitzahl an (5-stellig).

Open field for 5 digits

D4.

Wie viele Einwohner hat die Stadt oder der Ort, in dem Sie leben?

Unter 5.000 Einwohner

5.000 bis unter 20.000 Einwohner

20.000 bis unter 100.000 Einwohner

100.000 bis unter 500.000 Einwohner

500.000 und mehr Einwohner

1 
D5.

Und welches ist Ihr letzter Schulabschluss?

\begin{tabular}{|l|c|}
\hline Grund-/Hauptschule ohne abgeschlossene Lehre & 1 \\
\hline Grund-/Hauptschule mit abgeschlossener Lehre & 2 \\
\hline Weiterführende Schule ohne Abitur/ Hochschulreife & 3 \\
\hline Weiterführende Schule mit Abitur/ Hochschulreife & 4 \\
\hline Universität/ Hochschule & 5 \\
\hline Keines der oben genannten trifft zu & 6 \\
\hline
\end{tabular}

\section{Show instruction below on a separate screen}

Bei dieser Befragung geht es um Ihre Essgewohnheiten innerhalb des letzten Jahres. Man hat manchmal Schwierigkeiten zu kontrollieren, wie viel man von bestimmten Nahrungsmitteln isst, beispielsweise:

- Süßwaren wie Eiscreme, Schokolade, Donuts und andere Backwaren, Kekse, Kuchen und andere Süßigkeiten

- Kohlenhydratreiche Nahrungsmittel wie Weißbrot, Brötchen, Nudeln und Reis

- Salzige Snacks wie Chips, Salzstangen und Cracker

- Fettreiche Nahrungsmittel wie Steak, Speck, Bratwurst, Hamburger, Döner, Pizza und Pommes Frites

- Zuckerhaltige Getränke wie Limonade, Cola, Fanta, Sprite und Energy Drinks

Wenn in den folgenden Fragen nach bestimmten Nahrungsmitteln gefragt wird, denken Sie bitte an irgendein Nahrungsmittel oder Getränk ähnlich wie in den oben aufgelisteten Gruppen von Nahrungsmitteln und Getränken oder denken Sie an irgendein anderes Nahrungsmittel, bei dem Sie im vergangenen Jahr Schwierigkeiten hatten dessen Konsum zu kontrollieren.

\section{New screen}

F1.

Bitte geben Sie an, wie häufig die folgenden Aussagen für Sie für die letzten 12 Monate zutreffen.

Bitte geben Sie eine Antwort pro Zeile an

CAI show 7 attributes on one screen

\begin{tabular}{|l|c|c|c|c|c|c|c|c|}
\hline IN DEN LETZEN 12 MONATEN: & Nie & $\begin{array}{l}\text { Seltener } \\
\text { als 1 } \\
\text { pro } \\
\text { Monat }\end{array}$ & $\begin{array}{l}1 \times \\
\text { pro } \\
\text { Monat }\end{array}$ & $\begin{array}{l}2-3 \times \\
\text { pro } \\
\text { Monat }\end{array}$ & $\begin{array}{l}1 \times \\
\text { pro } \\
\text { Woche }\end{array}$ & $\begin{array}{l}2-3 \times \\
\text { pro } \\
\text { Woche }\end{array}$ & $\begin{array}{l}4-6 x \\
\text { pro } \\
\text { Woche }\end{array}$ & $\begin{array}{l}\text { Jeden } \\
\text { Tag }\end{array}$ \\
\hline $\begin{array}{l}\text { 1. Wenn ich anfing bestimmte } \\
\text { Nahrungsmittel zu essen, aß ich viel } \\
\text { mehr als geplant. }\end{array}$ & 0 & 0 & 0 & 0 & 0 & 0 & 0 & 0 \\
\hline $\begin{array}{l}\text { 2. Ich aß bestimmte Nahrungsmittel } \\
\text { weiter, obwohl ich nicht mehr } \\
\text { hungrig war. }\end{array}$ & 0 & 0 & 0 & 0 & 0 & 0 & 0 & 0 \\
\hline $\begin{array}{l}\text { 3. Ich aß bis zu einem Punkt, an } \\
\text { dem ich mich körperlich schlecht } \\
\text { fühlte. }\end{array}$ & 0 & 0 & 0 & 0 & 0 & 0 & 0 & 0 \\
\hline
\end{tabular}




\begin{tabular}{|c|c|c|c|c|c|c|c|c|}
\hline $\begin{array}{l}\text { 4. Ich machte mir viele Gedanken } \\
\text { darüber, den Konsum bestimmter } \\
\text { Nahrungsmittel einzuschränken, } \\
\text { aber ich aß sie trotzdem. }\end{array}$ & 0 & 0 & 0 & $\mathrm{O}$ & 0 & 0 & O & O \\
\hline $\begin{array}{l}\text { 5. Ich verbrachte viel Zeit, in der } \\
\text { ich mich träge oder müde fühlte, } \\
\text { weil ich mich überessen hatte. }\end{array}$ & 0 & 0 & 0 & 0 & $\mathrm{O}$ & 0 & 0 & $\mathrm{O}$ \\
\hline IN DEN LETZEN 12 MONATEN: & Nie & $\begin{array}{l}\text { Seltener } \\
\text { als } 1 \times \\
\text { pro } \\
\text { Monat }\end{array}$ & $\begin{array}{l}1 \times \\
\text { pro } \\
\text { Monat }\end{array}$ & $\begin{array}{l}2-3 x \\
\text { pro } \\
\text { Monat }\end{array}$ & $\begin{array}{l}1 \times \\
\text { pro } \\
\text { Woche }\end{array}$ & $\begin{array}{l}2-3 \times \\
\text { pro } \\
\text { Woche }\end{array}$ & $\begin{array}{l}4-6 \times \\
\text { pro } \\
\text { Woche }\end{array}$ & $\begin{array}{c}\text { Jeden } \\
\text { Tag }\end{array}$ \\
\hline $\begin{array}{l}\text { 6. Ich verbrachte viel Zeit, in der } \\
\text { ich bestimmte Nahrungsmittel über } \\
\text { den ganzen Tag hinweg aß. }\end{array}$ & $\mathrm{O}$ & 0 & $\mathrm{O}$ & $\mathrm{O}$ & 0 & $\mathrm{O}$ & $\mathrm{O}$ & $\mathrm{O}$ \\
\hline $\begin{array}{l}\text { 7. Wenn bestimmte Nahrungsmittel } \\
\text { nicht vorhanden waren, scheute ich } \\
\text { keine Mühen diese zu bekommen. } \\
\text { Zum Beispiel ging ich in den } \\
\text { Supermarkt um bestimmte } \\
\text { Nahrungsmittel zu kaufen, obwohl } \\
\text { ich andere Lebensmittel zuhause } \\
\text { hatte. }\end{array}$ & 0 & 0 & 0 & 0 & 0 & 0 & 0 & 0 \\
\hline $\begin{array}{l}\text { 8. Ich aß bestimmte Nahrungsmittel } \\
\text { so häufig oder in solch großen } \\
\text { Mengen, dass ich aufhörte andere } \\
\text { wichtige Dinge zu tun. Diese Dinge } \\
\text { konnten beispielsweise sein zu } \\
\text { arbeiten oder Zeit mit Familie oder } \\
\text { Freunden zu verbringen. }\end{array}$ & $\mathrm{O}$ & 0 & 0 & $\mathrm{O}$ & 0 & 0 & O & 0 \\
\hline $\begin{array}{l}\text { 9. Ich hatte Probleme mit meiner } \\
\text { Familie oder Freunden aufgrund der } \\
\text { Häufigkeit meines Überessens. }\end{array}$ & 0 & 0 & 0 & $\mathrm{O}$ & 0 & 0 & $\mathrm{O}$ & $\mathrm{O}$ \\
\hline $\begin{array}{l}\text { 10. Ich mied die Arbeit, Schule oder } \\
\text { soziale Aktivitäten, weil ich } \\
\text { befürchtete mich dort zu überessen. }\end{array}$ & 0 & 0 & 0 & 0 & 0 & 0 & $\mathrm{O}$ & 0 \\
\hline $\begin{array}{l}\text { 11. Wenn ich den Konsum } \\
\text { bestimmter Nahrungsmittel } \\
\text { einschränkte oder ganz aufhörte sie } \\
\text { zu essen, fühlte ich mich gereizt, } \\
\text { nervös oder traurig. }\end{array}$ & $\mathrm{O}$ & 0 & 0 & $\mathrm{O}$ & 0 & 0 & 0 & 0 \\
\hline $\begin{array}{l}\text { 12. Wenn ich körperliche Symptome } \\
\text { spürte, weil ich bestimmte } \\
\text { Nahrungsmittel nicht gegessen } \\
\text { hatte, aß ich diese Nahrungsmittel } \\
\text { um mich besser zu fühlen. }\end{array}$ & 0 & 0 & 0 & 0 & 0 & 0 & 0 & 0 \\
\hline $\begin{array}{l}\text { 13. Wenn ich emotionale Probleme } \\
\text { hatte, weil ich bestimmte } \\
\text { Nahrungsmittel nicht gegessen } \\
\text { hatte, aß ich diese Nahrungsmittel } \\
\text { um mich besser zu fühlen. }\end{array}$ & 0 & 0 & 0 & 0 & 0 & 0 & 0 & 0 \\
\hline $\begin{array}{l}\text { 14. Wenn ich den Konsum } \\
\text { bestimmter Nahrungsmittel } \\
\text { einschränkte oder ganz aufhörte sie } \\
\text { zu essen, verspürte ich körperliche } \\
\text { Symptome. Zum Beispiel hatte ich } \\
\text { Kopfschmerzen oder fühlte mich } \\
\text { müde oder schlapp. }\end{array}$ & 0 & 0 & 0 & 0 & 0 & 0 & 0 & 0 \\
\hline
\end{tabular}




\begin{tabular}{|c|c|c|c|c|c|c|c|c|}
\hline $\begin{array}{l}\text { 15. Wenn ich den Konsum } \\
\text { bestimmter Nahrungsmittel } \\
\text { einschränkte oder ganz aufhörte sie } \\
\text { zu essen, verspürte ich ein starkes } \\
\text { Verlangen nach ihnen. }\end{array}$ & 0 & 0 & 0 & 0 & 0 & 0 & $\mathrm{O}$ & $\mathrm{O}$ \\
\hline $\begin{array}{l}\text { 16. Mein Essverhalten verursachte } \\
\text { mir sehr viel Leid. }\end{array}$ & 0 & $\mathrm{O}$ & 0 & $\mathrm{O}$ & 0 & 0 & $\mathrm{O}$ & $\mathrm{O}$ \\
\hline $\begin{array}{l}\text { 17. Ich hatte erhebliche Probleme in } \\
\text { meinem Leben aufgrund von } \\
\text { Nahrung und Essen. Diese Probleme } \\
\text { betrafen beispielsweise meinen } \\
\text { Alltag, die Arbeit, die Schule, } \\
\text { Freunde, Familie oder meine } \\
\text { Gesundheit. }\end{array}$ & 0 & 0 & 0 & $\mathrm{O}$ & 0 & 0 & 0 & 0 \\
\hline IN DEN LETZEN 12 MONATEN: & Nie & $\begin{array}{l}\text { Seltener } \\
\text { als } 1 \times \\
\text { pro } \\
\text { Monat }\end{array}$ & $\begin{array}{l}1 \times \\
\text { pro } \\
\text { Monat }\end{array}$ & $\begin{array}{l}2-3 x \\
\text { pro } \\
\text { Monat }\end{array}$ & $\begin{array}{l}1 \times \\
\text { pro } \\
\text { Woche }\end{array}$ & $\begin{array}{l}2-3 x \\
\text { pro } \\
\text { Woche }\end{array}$ & $\begin{array}{l}4-6 \times \\
\text { pro } \\
\text { Woche }\end{array}$ & $\begin{array}{c}\text { Jeden } \\
\text { Tag }\end{array}$ \\
\hline $\begin{array}{l}\text { 18. Ich hatte ein so schlechtes } \\
\text { Gewissen aufgrund des Überessens, } \\
\text { dass ich andere wichtige Dinge nicht } \\
\text { tat. Diese Dinge konnten } \\
\text { beispielsweise sein zu arbeiten oder } \\
\text { Zeit mit Familie oder Freunden zu } \\
\text { verbringen. }\end{array}$ & 0 & 0 & 0 & 0 & $\mathrm{O}$ & 0 & $\mathrm{O}$ & $\mathrm{O}$ \\
\hline $\begin{array}{l}\text { 19. Mein Überessen stand mir dabei } \\
\text { im Weg mich um meine Familie zu } \\
\text { kümmern oder meine häuslichen } \\
\text { Pflichten zu erledigen. }\end{array}$ & 0 & 0 & 0 & $\mathrm{O}$ & 0 & 0 & $\mathrm{O}$ & 0 \\
\hline $\begin{array}{l}\text { 20. Ich mied die Arbeit, Schule oder } \\
\text { soziale Aktivitäten, weil ich } \\
\text { bestimmte Nahrungsmittel dort } \\
\text { nicht essen konnte. }\end{array}$ & 0 & 0 & 0 & 0 & $\mathrm{O}$ & 0 & $\mathrm{O}$ & 0 \\
\hline $\begin{array}{l}\text { 21. Ich mied soziale Situationen, } \\
\text { weil Menschen es nicht akzeptiert } \\
\text { hätten wie viel ich gegessen hätte. }\end{array}$ & 0 & 0 & 0 & 0 & 0 & 0 & 0 & 0 \\
\hline $\begin{array}{l}\text { 22. Ich aß in derselben Art und } \\
\text { Weise weiter, obwohl mein } \\
\text { Essverhalten emotionale Probleme } \\
\text { verursachte. }\end{array}$ & 0 & 0 & 0 & $\mathrm{O}$ & 0 & 0 & 0 & 0 \\
\hline $\begin{array}{l}\text { 23. Ich aß in derselben Art und } \\
\text { Weise weiter, obwohl mein } \\
\text { Essverhalten körperliche Probleme } \\
\text { verursachte. }\end{array}$ & 0 & 0 & 0 & $\mathrm{O}$ & 0 & 0 & 0 & 0 \\
\hline $\begin{array}{l}\text { 24. Die gleiche Nahrungsmenge zu } \\
\text { essen brachte mir nicht den } \\
\text { gleichen Genuss wie früher. }\end{array}$ & 0 & 0 & 0 & 0 & 0 & 0 & 0 & 0 \\
\hline $\begin{array}{l}\text { 25. Ich wollte unbedingt den } \\
\text { Konsum bestimmter Nahrungsmittel } \\
\text { einschränken oder ganz auf sie } \\
\text { verzichten, aber ich konnte es } \\
\text { einfach nicht. }\end{array}$ & 0 & 0 & 0 & 0 & 0 & 0 & 0 & 0 \\
\hline $\begin{array}{l}\text { 26. Ich musste immer mehr essen } \\
\text { um die Gefühle zu bekommen, die } \\
\text { ich durch essen erreichen wollte. } \\
\text { Diese umfassten eine Verminderung } \\
\text { negativer Emotionen wie Traurigkeit } \\
\text { oder eine Erhöhung des } \\
\text { Wohlbefindens. }\end{array}$ & 0 & 0 & 0 & 0 & 0 & 0 & O & 0 \\
\hline
\end{tabular}




\begin{tabular}{|c|c|c|c|c|c|c|c|c|}
\hline $\begin{array}{l}\text { 27. Ich erbrachte keine gute } \\
\text { Leistung auf der Arbeit oder in der } \\
\text { Schule, weil ich zu viel aß. }\end{array}$ & $\mathrm{O}$ & 0 & 0 & $\mathrm{O}$ & 0 & $\mathrm{O}$ & $\mathrm{O}$ & 0 \\
\hline $\begin{array}{l}\text { 28. Ich aß bestimmte } \\
\text { Nahrungsmittel weiterhin, obwohl } \\
\text { ich wusste, dass es körperlich } \\
\text { gefährlich war. Zum Beispiel aß ich } \\
\text { weiterhin Süßigkeiten, obwohl ich } \\
\text { Diabetes hatte oder ich aß weiterhin } \\
\text { fettreiche Nahrungsmittel, obwohl } \\
\text { ich eine Herzerkrankung hatte. }\end{array}$ & 0 & 0 & 0 & $\mathrm{O}$ & 0 & $\mathrm{O}$ & $\mathrm{O}$ & 0 \\
\hline $\begin{array}{l}\text { 29. Ich hatte einen solch starken } \\
\text { Drang bestimmte Nahrungsmittel zu } \\
\text { essen, dass ich an nichts anderes } \\
\text { mehr denken konnte. }\end{array}$ & $\mathrm{O}$ & 0 & 0 & $\mathrm{O}$ & 0 & $\mathrm{O}$ & $\mathrm{O}$ & 0 \\
\hline $\begin{array}{l}\text { 30. Ich hatte ein solch starkes } \\
\text { Verlangen nach bestimmten } \\
\text { Nahrungsmitteln, dass ich mich } \\
\text { fühlte als müsste ich sie sofort } \\
\text { essen. }\end{array}$ & 0 & 0 & 0 & 0 & 0 & 0 & 0 & 0 \\
\hline $\begin{array}{l}\text { 31. Ich versuchte den Konsum } \\
\text { bestimmter Nahrungsmittel } \\
\text { einzuschränken oder ganz } \\
\text { aufzuhören sie zu essen, aber ich } \\
\text { war erfolglos. }\end{array}$ & 0 & $\mathrm{O}$ & 0 & $\mathrm{O}$ & 0 & $\mathrm{O}$ & $\mathrm{O}$ & 0 \\
\hline IN DEN LETZEN 12 MONATEN: & $\mathrm{Nie}$ & $\begin{array}{l}\text { Seltener } \\
\text { als } 1 \mathrm{x} \\
\text { pro } \\
\text { Monat }\end{array}$ & $\begin{array}{l}1 \times \\
\text { pro } \\
\text { Monat }\end{array}$ & $\begin{array}{l}2-3 x \\
\text { pro } \\
\text { Monat }\end{array}$ & $\begin{array}{l}1 \times \\
\text { pro } \\
\text { Woche }\end{array}$ & $\begin{array}{l}2-3 x \\
\text { pro } \\
\text { Woche }\end{array}$ & $\begin{array}{l}4-6 x \\
\text { pro } \\
\text { Woche }\end{array}$ & $\begin{array}{l}\text { Jeden } \\
\text { Tag }\end{array}$ \\
\hline $\begin{array}{l}\text { 32. Ich versuchte und versagte } \\
\text { dabei den Konsum bestimmter } \\
\text { Nahrungsmittel einzuschränken } \\
\text { oder ganz auf sie zu verzichten. }\end{array}$ & $\mathrm{O}$ & 0 & 0 & 0 & 0 & $\mathrm{O}$ & 0 & 0 \\
\hline $\begin{array}{l}\text { 33. Ich war durch essen so } \\
\text { abgelenkt, dass ich mich hätte } \\
\text { verletzen können (z. B. während } \\
\text { des Autofahrens, beim Überqueren } \\
\text { der Straße oder beim Bedienen von } \\
\text { Maschinen). }\end{array}$ & 0 & 0 & $\mathrm{O}$ & 0 & $\mathrm{O}$ & $\mathrm{O}$ & $\mathrm{O}$ & 0 \\
\hline $\begin{array}{l}\text { 34. Ich war durch Gedanken an } \\
\text { Essen so abgelenkt, dass ich mich } \\
\text { hätte verletzten können (z.B. } \\
\text { während des Autofahrens, beim } \\
\text { Überqueren der Straße oder beim } \\
\text { Bedienen von Maschinen). }\end{array}$ & 0 & 0 & 0 & $\mathrm{O}$ & 0 & $\mathrm{O}$ & $\mathrm{O}$ & $\mathrm{O}$ \\
\hline $\begin{array}{l}\text { 35. Meine Freunde oder Familie } \\
\text { machten sich Sorgen darüber, wie } \\
\text { häufig ich mich überaß. }\end{array}$ & 0 & 0 & 0 & 0 & 0 & 0 & 0 & 0 \\
\hline
\end{tabular}

F2.

Wie häufig treiben Sie Sport?

Bitte nur eine Antwort angeben

\begin{tabular}{|l|}
\hline IN DEN LETZEN 12 MONATEN: \\
\hline Nie \\
\hline Seltener als $1 \times$ pro Monat \\
\hline $1 \times$ pro Monat \\
\hline $2-3 \times$ pro Monat \\
\hline
\end{tabular}




\section{Anhang}

\begin{tabular}{|l|}
\hline $1 \times$ pro Woche \\
\hline $2-3 \times$ pro Woche \\
\hline 4-6 $\times$ pro Woche \\
\hline Jeden Tag \\
\hline
\end{tabular}

F3.

Wie häufig haben Sie Alltagsbewegungen, wie Spazierengehen mit dem Hund oder Fahrradfahren zur Arbeit, die mind. 30 Minuten dauern?

Bitte nur eine Antwort angeben

\begin{tabular}{|l|}
\hline IN DEN LETZEN 12 MONATEN: \\
\hline Nie \\
\hline Seltener als $1 \times$ pro Monat \\
\hline $1 \times$ pro Monat \\
\hline $2-3 \times$ pro Monat \\
\hline $1 \times$ pro Woche \\
\hline $2-3 \times$ pro Woche \\
\hline $4-6 \times$ pro Woche \\
\hline Jeden Tag \\
\hline
\end{tabular}

Im Folgenden möchten wir Ihnen noch ein paar allgemeine Fragen stellen

F4.

Wie groß sind Sie?

Bitte geben Sie Ihre Größe in Zentimetern an.

$\mathrm{cm}$

F5.

Wieviel wiegen Sie?

Bitte geben Sie Ihr Gewicht in $\mathrm{kg}$ an.

$\mathrm{kg}$

F6.

Wie viele Personen leben ständig in Ihrem Haushalt, Sie selbst eingeschlossen?

Bitte nur eine Antwort angeben

\begin{tabular}{|l|}
\hline 1 \\
\hline 2 \\
\hline 3 \\
\hline 4 \\
\hline
\end{tabular}




\section{Anhang}

\begin{tabular}{|l|}
\hline 5 \\
\hline 6 \\
\hline 7 oder mehr \\
\hline
\end{tabular}

F7.

Mit wem wohnen Sie derzeit zusammen?

Bitte nur eine Antwort angeben

Mit meinen Eltern

Mit meinem Partner/ Ehemann/ Ehefrau und Kindern

Nur mit meinem Partner/ Ehemann/ Ehefrau ohne Kinder

Mit meinen Kindern (ohne Ehemann/Partner)

Mit Freunden/ WG in einer Wohnung/ Haus 
Anhang

Klinische Stichprobe 
Institut für Ernährungspsychologie an der Georg-August Universität

Göttingen

Universitätsmedizin

PD Dr. med. Thomas Ellrott Institutsleiter

Carolin Hauck Kontakt Humboldtallee 32, 37073 Göttingen Adresse

0551 / 39-8964 Telefon

0551/39-9621 Fax

carolinhauck@med.uni-goettingen.de E-Mail www.ernaehrungspsychologie.org Web

25.08.2016 Datum

Ethikkommission der Universitätsmedizin Göttingen

Von-Siebold-Str.3

37075 Göttingen

Referentin: Regierungsrätin Doris Wettschereck

Sekretariat: Manuela Gödicke

Email: ethik@med.uni-goettingen.de

Tel.: ++49 (0)5513966629

Fax: ++49 (0)551399536

\section{Anschreiben an die Ethikkommission über eine Dissertation an der Universitätsmedizin Göttingen}

Sehr geehrte Frau Wettschereck,

für ein Forschungsvorhaben des Instituts für Ernährungspsychologie, An-Institut der

Universitätsmedizin Göttingen, reichen wir folgendes Informationsblatt für die

Ethikkommission ein. Bei dem Forschungsvorhaben handelt es sich um eine Erhebung zu meiner Doktorarbeit.

Wir bitten um Prüfung des geplanten Forschungsvorhabens durch die Ethikkommission.

Vielen Dank und beste Grüße

Thomas Ellrott und Carolin Hauck 

der Universitätsmedizin Göttingen

Betreuer/In: PD Dr. med. Thomas Ellrott

Abteilungen: Institut für Ernährungspsychologie in Kooperation mit der Klinik für Gastroenterologie

e-mail Betreuer: tellrot@med.uni-goettingen.de
Name: Hauck

Datum: 25.08.2016

e-mail Doktorand: carolinhauck@med.uni-goettingen.de

\section{Vorläufiges Thema:}

Zusammenhang zwischen „Esssucht“/ ,Food Addiction', gezügeltem Essverhalten, mentalem Gesundheitsstatus und Heißhungerattacken bei morbider Adipositas

English version: Relationship between 'Food Addiction', restrained eating behaviour, mental health status and score of binge eating in a morbidly obese German sample

Bitte geben Sie ein kurzes Abstract des geplanten Forschungsvorhabens (nicht mehr als 10 Zeilen!; leserlich)

Im Zuge steigender Prävalenz von Übergewicht und Adipositas werden derzeit neue Erklärungsansätze erforscht. Einer dieser Ansätze ist das Konstrukt einer ,Food Addiction', die möglicherweise zum Überkonsum an Nahrung beitragen könnte. Unklar ist derzeit, ob es eine ,Food Addiction' im Sinne einer

Substanzgebrauchsstörung nach dem DSM-5 gibt, und welche Zusammenhänge diese mit Essverhalten, mentalem Gesundheitsstatus und Heißhungerattacken aufweist.

Hierzu wird die Prävalenz von ,Food Addiction' in einer morbid adipösen Stichprobe von Patienten, die sich an der UMG zur Therapie befinden, ausgewertet. Dazu werden 3 Fragebögen genutzt, die im Rahmen der klinischen Eingangs- und Verlaufsdiagnostik routinemäßig zur klinischen Evaluation verwendet werden: „Yale Food Addiction Scale 2.0“ (YFAS 2.0), ein erweiterter „Fragebogen zum Essverhalten“ (TFEQ/FEV+) sowie der „Short Form 36“" (SF-36). Zusätzliche Untersuchungen werden nicht durchgeführt.

\section{Mein Forschungsvorhaben hat die folgenden Eigenschaften:}

Medizinische Forschung mit Interventionen am Menschen (Eingriffe in Körper oder Psyche)

Forschung mit Kindern und Jugendlichen

Forschung mit nicht-einwilligungsfähigen Patienten

Untersuchungen an menschlichem Gewebe oder anderen Körpermaterialien (einschl. genetischer Untersuchungen)

Nachfragen bei (ehemaligen) Patienten oder Angehörigen; Nachfragen zu patientenbezogenen

Daten bei Ärzten außerhalb der Universitätsmedizin Göttingen

Forschung an Verstorbenen

Fragebogenstudie oder Interview-Studie mit Erhebung personenbezogener Daten zu Gesundheit oder Sexualität

Forschung mit personenbezogenen Daten von Patienten oder ihren Angehörigen (Krankenakte / elektronischer Datenzugriff

Ethik-Antrag liegt bereits vor (Antragsnummer ..) ja

nein

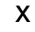

$\mathrm{X}$

$\mathrm{X}$

$x$

$\mathrm{X}$

$\mathrm{X}$

$\mathrm{X}$

Wir weisen darauf hin, dass sich ergebende grundlegende Änderungen im Studiendesign der Ethikkommission angezeigt werden müssen, sofern der Vorgang generell als vorlagepflichtig eingestuft wird. 
Herrn

PD Dr. med. Thomas Ellrott Regierungsrätin Doris Wettschereck 0551 / 39-8644 Telefon

Institut für Ernährungspsychologie

an der Universität Göttingen

Von-Siebold-Straße 3, 37075 Göttingen

Humboldtallee 32

Adresse

0551 / 39-66629 Telefon

0551 / 39-9536 Fax

ethik@med.uni-goettingen.de E-Mai

www.ethikkommission.med.uni-goettingen.de

vorab per E-Mail: tellrot@med.uni-goettingen.de

31.10.2016 br - ni Datum

Nachrichtlich an: Carolin Hauck, per E-Mail: carolinhauck@med.uni-goettingen.de

Antragsnummer:

Studientitel:

Antragsteller:

\section{DOK_130_2016 (bitte stets angeben)}

Zusammenhang zwischen „Esssucht"/ "Food Addiction", gezügeltem Essverhalten, mentalem Gesundheitsstatus und Heißhungerattacken bei morbider Adipositas

PD Dr. med. Thomas Ellrott, Institut für Ernährungspsychologie, UMG

Doktorandin: Carolin Hauck

Sehr geehrter Herr Dr. Ellrott, sehr geehrte Frau Hauck,

nach der uns vorgelegten Kurzdarstellung des oben genannten Promotionsprojektes sollen ausschließlich die an der UMG bereits gegenwärtig vorliegenden Behandlungsdaten oder bereits hier existierende Bilddaten ausgewertet werden. Eine derartige Auswertung ist entsprechend den allgemeinen Vertragsbedingungen für die Behandlung an der UMG und entsprechend dem niedersächsischen Datenschutzgesetz zulässig, wenn sichergestellt ist, dass keine personenbezogenen Daten an andere außerhalb der behandelnden Einrichtung weitergegeben werden.

Für Einrichtungen außerhalb der UMG gilt entsprechendes. Sofern dort die Patienten im Rahmen der dortigen allgemeinen Geschäftsbedingungen oder im Rahmen der Behandlungsverträge über die wissenschaftliche Auswertung der Behandlungsdaten informiert sind und dem nicht widersprochen haben, können die Daten unter Wahrung der ärztlichen Schweigepflicht innerhalb der Klinik von Mitgliedern des Behandlungsteams zu wissenschaftlichen Zwecken ausgewertet werden.

Entsprechend der Deklaration von Helsinki gehört auch die Analyse von medizinischen Daten in den Bereich der medizinischen Forschung und muss damit entsprechend der ärztlichen Berufsordnung einer Ethikkommission vorgelegt werden. Dieser Verpflichtung sind sie mit der Kurzdarstellung des Projektes nachgekommen.

\section{Gegen die oben genannte Doktorarbeit bestehen keine Bedenken.}

Auf folgendes möchten wir vorsorglich hinweisen:

1. Änderungen im Vorgehen bei diesem Projekt können einen Antrag an die Ethik-Kommission erforderlich machen. Dies betrifft beispielsweise die zusätzliche forschungsbedingte Einholung von weiteren Informationen von Patienten, von deren Angehörigen oder von externen Kliniken oder Ärzten. Dies betrifft aber z.B. auch zusätzliche forschungsbedingte Untersuchungen an biologischen Materialien, die den Patienten entnommen werden oder die an der UMG gelagert sind.

2. Wir gehen davon aus, dass ausschließlich Mitglieder des Behandlungsteams Zugang zu den Patientenakten bekommen. Dabei können insbesondere an unserem Universitätsklinikum die in Göttingen immatrikulierten Studierenden der Human- oder Zahnmedizin als Mitglieder des Behandlungsteams angesehen werden. 
3. Wir möchten bitten, dass die Doktorandin/der Doktorand eine Verschwiegenheitserklärung genau liest, mit der Betreuerin/dem Betreuer bespricht und unterschreibt. Diese Verschwiegenheitserklärung sollte für 10 Jahre bei den Unterlagen der Betreuer aufbewahrt werden. Die Doktorandinnen und Doktoranden sind im Rahmen der persönlichen Einweisung nachdrücklich darauf hinzuweisen, dass ein Verstoß gegen die ärztliche Schweigepflicht eine Straftat ist, die schwerwiegende Konsequenzen haben kann. Bei allen Unklarheiten bezüglich des Datenschutzes wenden Sie sich bitte an den Datenschutzbeauftragten der UMG, Herrn Dr. Langbein

4. Wir gehen davon aus, dass projektspezifisch keine personenbezogenen Daten (Namen, Anschriften, Klinikums-Behandlungsnummer, aus der für viele die Person identifizierbar ist etc.) gespeichert werden. Vielmehr sind die Daten pseudonymisiert unter Codes zu speichern, die keinen Rückschluss auf die Personen zulassen. Aus Datenschutzgründen müssen wir auch dringend davon abraten, etwa in Anhängen zur Doktorarbeit Listen der Einzeldaten zu führen, und zwar dies auch wenn die Daten natürlich ohne personenbezogene Informationen wie Name, Anschrift und Geburtsdatum gespeichert sind.

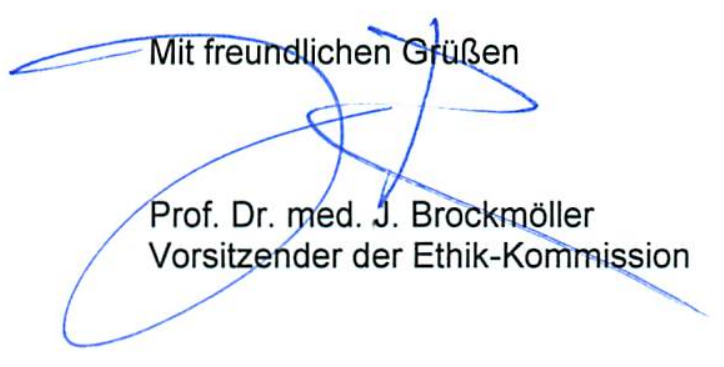


Anhang

Sportlerstichprobe 
Anhang

Seite 01

Studie zu Sport und Ernährung

TITELSEITE

eine Kooperation zwischen dem

Institut für Ernährungspsychologie an der Georg-August Universität Göttingen

und dem

Department Sportwissenschaft, Fachbereich Sportpsychologie der Martin-Luther-Universität HalleWittenberg 


\section{Studie zu Sport und Ernährung}

Willkommen zu unserer Studie, in der wir die vielfältigen Zusammenhänge zwischen Sport und Ernährung untersuchen.

Sie finden daher nachfolgend sowohl Fragen zu Ihren sportlichen Aktivitäten als auch zu Ihren Essgewohnheiten.

Unter Sport verstehen wir jegliche geregelte Aktivität die Ihre Herzfrequenz erhöht, wie z.B. Schwimmen, Radfahren, Laufen, Aerobic, Krafttraining, usw.

Wir fragen Sie auch nach Lebensmitteln, die Sie gerne und häufig verzehren und nach etwaigen Schwierigkeiten im Umgang mit bestimmten Lebensmitteln, so wie diese von vielen Menschen beschrieben werden.

In diesem Fragenbogen gibt es keine richtigen oder falschen Antworten. Es geht vielmehr darum, ob eine Aussage für Sie persönlich zutrifft oder nicht. Im Nachfolgenden finden Sie manchmal auch Aussagen, die von anderen Personen gemacht wurden, um deren Einstellung zu Sport und

Essgewohnheiten zu beschreiben. Bitte entscheiden Sie bei solchen Fragen jedes Mal, inwieweit dieser Satz auch auf Sie zutrifft. Dazu wählen Sie bitte die passende Antwortmöglichkeit aus, die Ihre eigene Einstellung gegenüber Ihrer sportlichen Aktivität / Ihren Essgewohnheiten für den jeweils angegebenen Zeitraum am besten beschreibt.

Bitte überlegen Sie nicht lange, sondern geben Sie die erste spontane Antwort, die Ihnen in den Sinn kommt an.

Als Dankeschön für Ihre Teilnahme verlosen wir unter allen komplett ausgefültten Fragebögen 3 Amazon-Gutscheine à $50 €$.

Die Befragung wird ca. 15 - 25 Minuten dauern und ist komplett anonymisiert, Rückschlüsse auf individuelle Personen sind nicht möglich.

Herzlichen Dank für Ihre Teilnahme! 
Seite 03

FE01 日 
Bitte bewerten Sie spontan die nachfolgenden Aussagen bezogen auf $\mathrm{Ihr}$ Sportverhalten in den letzten 4-6 Wochen.

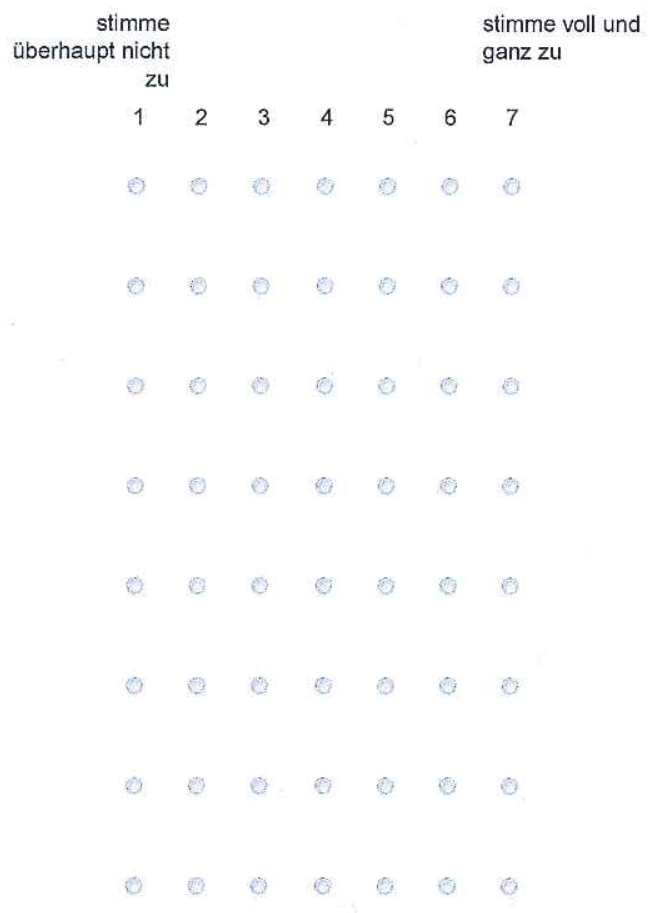

8. Wenn ich keinen Sport treiben kann fühle ich mich dem Leben nicht gewachsen. 
9. Ich treibe Sport um mich von aufkommender Anspannung / Gereiztheit zu befreien.

10. Ich fühle mich meiner Familie gegenüber schuldig wegen der Menge an Sport die ich treibe.

11. Ich treibe Sport um gesünder zu sein

12. Die Menge an Sport die ich treibe ist zu einem Problem geworden.

13. Nach einer Sporteinheit bin ich mit mir und der Welt zufrieden.

14. Meine Sportumfänge kollidieren mit meinem Sozialleben.

15. Ich treibe Sport um mich fit zu fühlen.

16. Ich treibe Sport um Herzerkrankungen und anderen Krankheiten vorzubeugen. 
Anhang

Seite 04

YF01 미 
1. Bei dieser Befragung geht es um Ihre Essgewohnheiten innerhalb des letzten Jahres. Man hat manchmal Schwierigkeiten zu kontrollieren, wie viel man von bestimmten Nahrungsmitteln isst, beispielsweise:

- Süßwaren wie Schokolade

- Salzige Snacks wie Cracker

- Zuckerhaltige Getränke wie Limonade und Engergy Drinks

Wenn in den folgenden Fragen nach bestimmten Nahrungsmitteln gefragt wird, denken Sie bitte an ein bestimmtes Nahrungsmittel oder Getränk ähnlich wie in den oben aufgelisteten

Gruppen von Nahrungsmitteln und Getränken oder denken Sie an irgendein anderes

Nahrungsmittel, bei dem Sie im vergangenen Jahr Schwierigkeiten hatten, dessen Konsum zu kontrollieren.

Bitte kreuzen Sie Zutreffendes an:

In den letzten 12 Monaten:

1. Wenn ich anfing bestimmte

Nahrungsmittel zu essen, aß ich viel mehr als geplant.

2. Ich $a ß$

bestimmte

Nahrungsmittel

weiter, obwohl ich

nicht mehr hungrig

war.

3. Ich aß bis zu einem Punkt, an dem ich mich körperlich schlecht fühlte.

4. Ich machte mir viele Gedanken darüber, den

Konsum

bestimmter

Nahrungsmittel einzuschränken, aber ich $a ß$ sie trotzdem.

5. Ich verbrachte viel Zeit, in der ich mich träge oder müde fühlte, weil ich mich überessen hatte.

6. Ich verbrachte viel Zeit, in der ich bestimmte

Nahrungsmittel über den ganzen Tag hinweg $a ß$.

7. Wenn bestimmte Nahrungsmittel nicht vorhanden waren, scheute ich keine Mühen diese zu bekommen.

Zum Beispiel ging ich in den

Supermarkt um bestimmte Nahrungsmittel zu kaufen, obwohl ich andere

Lebensmittel 
zuhause hatte.

8. Ich $a ß$

bestimmte

Nahrungsmittel so

häufig oder in

solch großen

Mengen, dass ich

aufhörte andere

wichtige Dinge zu

tun. Diese Dinge

konnten

beispielsweise sein

zu arbeiten oder

Zeit mit Familie

oder Freunden zu

verbringen.

9. Ich hatte

Probleme mit

meiner Familie

oder Freunden

aufgrund der

Häufigkeit meines

Überessens.

10. Ich mied die

Arbeit, Schule oder soziale Aktivitäten,

weil ich befürchtete mich dort zu

überessen.

11. Wenn ich den Konsum

bestimmter

Nahrungsmittel

einschränkte oder

ganz aufhörte sie

zu essen, fühlte ich

mich gereizt,

nervös oder

traurig.

12. Wenn ich

körperliche

Symptome spürte, weil ich bestimmte Nahrungsmittel nicht gegessen hatte, aß ich diese Nahrungsmittel um mich besser zu

fühlen.

13. Wenn ich emotionale Probleme hatte, weil ich bestimmte Nahrungsmittel nicht gegessen hatte, $a ß$ ich diese Nahrungsmittel um mich besser zu

fühlen.

14. Wenn ich den Konsum bestimmter Nahrungsmittel einschränkte oder ganz aufhörte sie zu essen, 
verspürte ich

körperliche

Symptome. Zum

Beispiel hatte ich

Kopfschmerzen

oder fühlte mich

müde oder

schlapp.

15. Wenn ich den

Konsum

bestimmter

Nahrungsmittel

einschränkte oder ganz aufhörte sie

zu essen,

verspürte ich ein

starkes Verlangen

nach innen.

16. Mein

Essverhalten

verursachte mir

sehr viel Leid.

17. Ich hatte

erhebliche

Probleme in

meinem Leben

aufgrund von

Nahrung und

Essen. Diese

Probleme betrafen

bespielsweise

meinen Alltag, die

Arbeit, die Schule,

Freunde, Familie

oder meine

Gesundheit.

18. Ich hatte ein so

schlechtes

Gewissen

aufgrund des

Überessens, dass

ich andere wichtige

Dinge nicht tat.

Diese Dinge

konnten

beispielsweise sein

zu arbeiten oder

Zeit mit Familie

oder Freunden zu

verbringen.

19. Mein

Überessen stand mir dabei im Weg

mich um meine

Familie zu

kümmern oder

meine häuslichen

Pflichten zu

erledigen.

20. Ich mied die Arbeit, Schule oder soziale Aktivitäten, weil ich bestimmte

Nahrungsmittel dort nicht essen konnte. 
21. Ich mied

soziale

Situationen, weil

Menschen es nicht

aktzeptiert hätten

wie viel ich

gegessen hätte.

22. Ich $a ß$ in derselben Art und

Weise weiter,

obwohl mein

Essverhalten

emotionale

Probleme

verursachte.

23. Ich $a ß$ in derselben Art und Weise weiter, obwohl mein

Essverhalten

körperliche

Probleme

verursachte.

24. Die gleiche

Nahrungsmenge

zu essen brachte

mir nicht den

gleichen Genuss

wie früher.

25. Ich wollte

unbedingt den

Konsum

bestimmter

Nahrungsmittel

einschränken oder

ganz auf sie

verzichten, aber

ich konnte es

einfach nicht.

26. Ich musste immer mehr essen um die Gefühle zu bekommen, die ich durch essen erreichen wollte.

Diese umfassten eine Verminderung negativer

Emotionen wie Traurigkeit oder eine Erhöhung des Wohlbefindens.

27. Ich erbrachte keine gute Leistung auf der Arbeit oder in der Schule, weil ich zu viel $\mathrm{a}$.

28. Ich $a ß$ bestimmte Nahrungsmittel weiterhin, obwohl ich wusste, dass es körperlich gefährlich war. Zum Beispiel aß 
ich weiterhin

Süßigkeiten,

obwohl ich

Diabetes hatte

oder ich $\mathrm{a} ß$

weiterhin fettreiche

Nahrungsmittel

obwohl ich eine

Herzerkrankung

hatte.

29. Ich hatte einen Seltener als

$1 \times 1$ pro $1 \times$ pro $2-3 \times$ pro $1 \times$ pro $2-3 \times$ pro $4-6 \times$ pro

solch starken

Drang bestimmte

Nahrungsmittel zu

essen, dass ich an

nichts anderes

mehr denken

konnte.

30. Ich hatte ein solch starkes

Verlangen nach

bestimmten

Nahrungsmitteln,

dass ich mich

fühlte als müsste

ich sie sofort

essen.

31. Ich versuchte

den Konsum

bestimmter

Nahrungsmittel

einzuschränken

oder ganz

aufzuhören sie zu

essen, aber ich

war erfolglos.

32. Ich versuchte

und versagte

dabei, den

Konsum

bestimmter

Nahrungsmittel

einzuschränken

oder ganz auf sie

zu verzichten.

33. Ich war durch

essen so

abgelenkt, dass ich

mich hätte

verletzten können

(z.B. während des

Autofahrens, beim

Überqueren der

Straße oder beim

Bedienen von

Maschinen).

34. Ich war durch

Gedanken an

Essen so

abgelenkt, dass ich

mich hätte

verletzten können

(z.B. während des

Autofahrens, beim

Überqueren der

Straße oder beim

Bedienen von 
Anhang

Maschinen)

35. Meine Freunde oder Familie

machten sich

Sorgen darüber,

wie häufig ich mich

überaß. 
Seite 05

2. Geben Sie bitte die Antwort an, die am Besten auf Sie zutrifft:

Während der letzten drei Monate...

\begin{tabular}{|c|c|c|c|c|c|c|c|c|}
\hline & $\begin{array}{l}\text { überhaupt } \\
\text { nicht }\end{array}$ & & etwas & & mäßig & & extrem & $\begin{array}{c}\text { kann ich } \\
\text { nicht } \\
\text { beurteilen }\end{array}$ \\
\hline $\begin{array}{l}\text { 1. Haben Sie sich } \\
\text { dick gefühlt? }\end{array}$ & 0 & 0 & 0 & 0 & 0 & $\theta$ & $\theta$ & 0 \\
\hline $\begin{array}{l}\text { 2. Hatten Sie } \\
\text { ausgesprochene } \\
\text { Angst an Gewicht } \\
\text { zuzunehmen oder } \\
\text { dick zu werden? }\end{array}$ & 0 & 0 & 0 & 0 & $\theta$ & 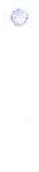 & 0 & 6 \\
\hline \multirow[t]{4}{*}{$\begin{array}{l}\text { 3. Hat ihr Gewicht } \\
\text { oder ihre Figur } \\
\text { beeinflusst wie Sie } \\
\text { über sich selbst als } \\
\text { Person urteilen? }\end{array}$} & 8 & 8 & $\theta$ & 8 & 6 & $s$ & 6) & 0 \\
\hline & & & & & & & & ES03 \\
\hline & & & & & & & $\mathrm{Ja}$ & Nein \\
\hline & & & & & & & 1 & 0 \\
\hline
\end{tabular}

4. Gab es in den letzten drei Monaten Zeiten, in denen Sie eine Nahrungsmenge gegessen haben, die andere Menschen unter den gegebenen Umständen als ungewöhnlich groß ansehen würden (z.B. $500 \mathrm{ml}$ Eiscreme)?

5. Haben Sie, wenn Sie eine ungewöhnlich große Nahrungsmenge gegessen haben, das Gefühl von Kontrollverlust erlebt (z.B. nicht mit dem Essen aufhören zu können oder kontrollieren zu können, was oder wie viel Sie essen)?

6. Wie viele Male haben Sie durchschnittlich pro Monat in den letzten drei Monaten eine ungewöhnlich große Nahrungsmenge gegessen und das Gefühl von Kontrollverlust erlebt?
0
12

3

4

3. Wenn Sie sich überessen und dabei einen Kontrollverlust erlebt haben, haben Sie..

ESO5
7. viel schneller gegessen als normalerweise?
8. gegessen bis Sie sich unangenehm voll gefühlt haben?
9. große Nahrungsmengen gegessen, obwohl Sie nicht hungrig waren?
10. alleine gegessen, weil Sie sich dafür geschämt haben wie viel Sie aßen?
11. sich nach dem Überessen vor sich selbst geekelt, sich niedergeschlagen oder sehr schuldig gefühlt?

12. Beunruhigt es Sie sehr, wenn Sie sich unkontrolliert überessen? 
Um eine Gewichtszunahme zu verhindern oder den Folgen des Essens entgegenzuwirken, wie viele Male haben Sie durchschnittlich pro Monat in den letzten drei Monaten ...

13. sich erbrochen?

$\begin{array}{lllllllllllllllll}0 & 1 & 2 & 3 & 4 & 5 & 6 & 7 & 8 & 9 & 10 & 11 & 12 & 13 & 14 & 15 & >=16\end{array}$

14. Abführmittel (Laxanzien) oder harntreibende Mittel (Diuretika) genutzt?

$\begin{array}{lllllllllllllllll}0 & 1 & 2 & 3 & 4 & 5 & 6 & 7 & 8 & 9 & 10 & 11 & 12 & 13 & 14 & 15 & >=16\end{array}$

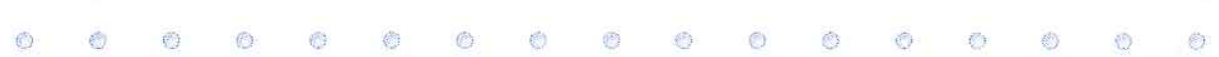

15. gefastet (mindestens zwei Mahlzeiten hintereinander ausgelassen)?

$\begin{array}{lllllllllllllllll}0 & 1 & 2 & 3 & 4 & 5 & 6 & 7 & 8 & 9 & 10 & 11 & 12 & 13 & 14 & 15 & >=16\end{array}$

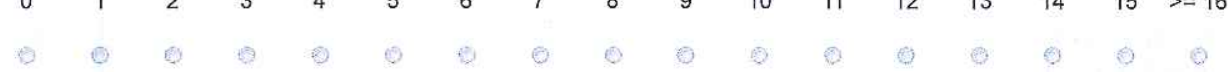

16. vermehrt Sport getrieben, um gezielt dem Effekt des Überessens entgegenzuwirken?

$\begin{array}{lllllllllllllllll}0 & 1 & 2 & 3 & 4 & 5 & 6 & 7 & 8 & 9 & 10 & 11 & 12 & 13 & 14 & 15 & >=16\end{array}$

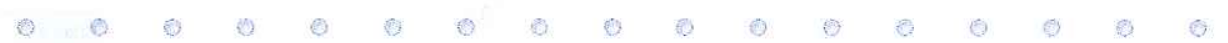

17. Wie viele Male haben Sie durchschnittlich pro Monat in den letzten drei Monaten gegessen, nachdem Sie nachts aus dem Schlaf aufgewacht sind oder haben eine ungewöhnlich große Nahrungsmenge nach dem Abendessen gegessen und litten unter diesem nächtlichen Essen?

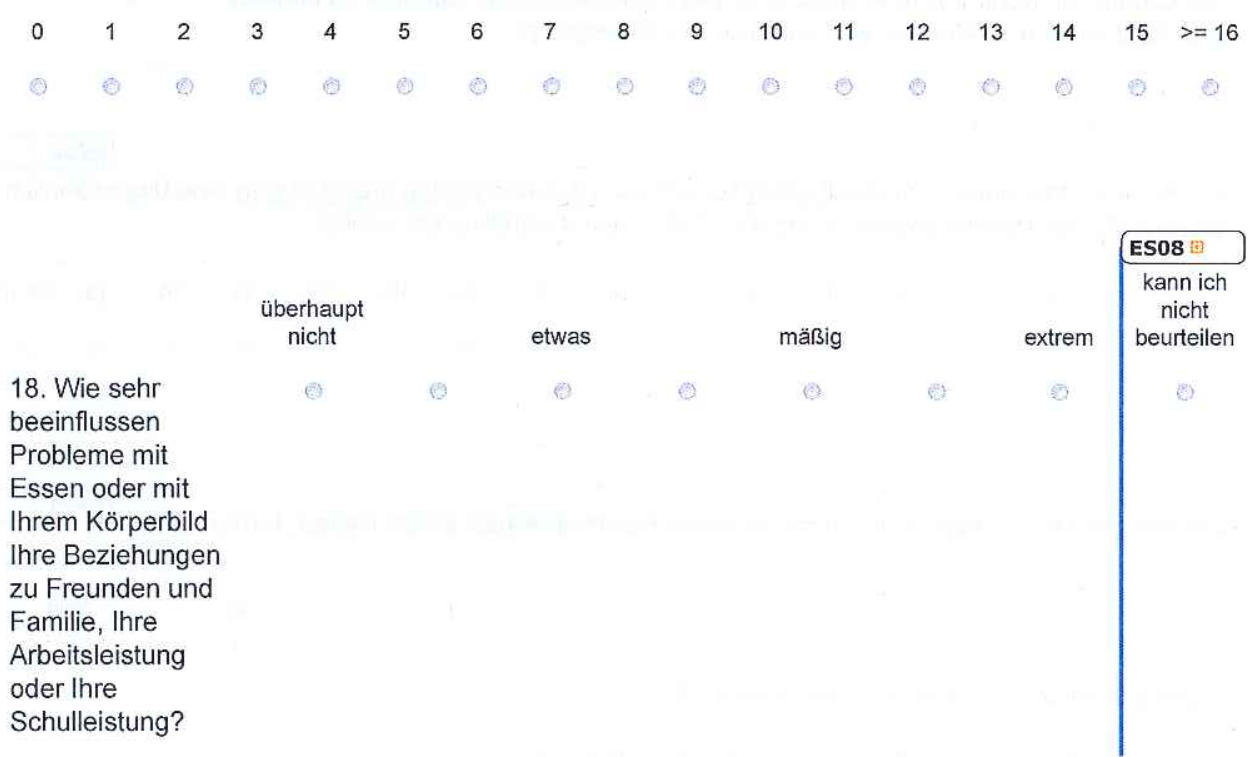


Seite 06

Beziehen Sie die folgenden Aussagen bitte immer auf Ihre Haupt-Sportart.

MI01 @

\begin{tabular}{|c|c|c|c|c|}
\hline $\begin{array}{l}\text { stimmt } \\
\text { überhaupt } \\
\text { nicht }\end{array}$ & $\begin{array}{l}\text { stimmt } \\
\text { weitgehend } \\
\text { nicht }\end{array}$ & $\begin{array}{l}\text { stimmt } \\
\text { eher } \\
\text { nicht }\end{array}$ & $\begin{array}{l}\text { stimmt } \\
\text { ein } \\
\text { wenig }\end{array}$ & $\begin{array}{l}\text { stimmt } \\
\text { weit } \\
\text { gehend }\end{array}$ \\
\hline
\end{tabular}

1. Nach dem TRAINING fühle ich mich niedergeschlagen, wenn ich nicht perfekt gewesen bin.

2. Im TRAINING strebe ich danach, so perfekt wie möglich zu sein.

3. Im TRAINING ärgere ich mich maßlos, wenn ich Fehler mache.

4. Im TRAINING möchte ich alles perfekt machen.

5. Wenn im TRAINING eine Sache nicht perfekt läuft, dann bin ich mit dem gesamten TRAINING unzufrieden.

6. Im TRAINING bin ich

perfektionistisch, was meine

Zielsetzung angeht.

7. Im TRAINING bin ich frustriert, wenn ich meine hohen Erwartungen nicht erfüllen kann.

8. Im TRAINING habe ich das Bedürfnis, perfekt zu ein.

9. Im TRAINING fühle ich mich extremst gestresst, wenn nicht alles perfekt läuft.

10. Im TRAINING habe ich den Wunsch alles perfekt zu machen. 
Anhang

Seite 07

FEV erweitert

FV01 
4. Für die folgenden Fragen bitte Zustimmung oder Ablehnung ankreuzen:

Ich kann mich bei einem leckeren Duft nur schwer vom Essen zurückhalten, auch wenn ich vor kurzer Zeit erst gegessen habe.

Ich esse gewöhnlich zuviel, wenn ich in Gesellschaft bin, z.B. bei Festen und Einladungen.

Ich bin meistens so hungrig, dass ich öfter zwischen den Mahlzeiten esse.

Wenn ich die Kalorienmenge erreicht habe, die ich mir als Grenze gesetzt habe, gelingt es mir meistens, mit dem Essen aufzuhören.

Weil ich zu großen Appetit habe, fällt es mir schwer, eine Diät einzuhalten.

Ich esse absichtlich kleine Portionen, um nicht zuzunehmen

Manchmal schmeckt es mir so gut, dass ich weiter esse, obwohl ich schon satt bin Manchmal wünsche ich mir, daß mir ein Fachmann sagt, ob ich satt bin oder noch mehr essen darf.

Wenn ich ängstlich oder angespannt bin, fange ich oft an zu essen.

Das Leben ist zu kurz, um sich auch noch mit Diät herumzuschlagen.

Ich habe schon mehr als einmal eine Schlankheitsdiät gemacht.

Oft habe ich ein so starkes Hungergefühl, dass ich einfach etwas essen muss.

Wenn ich mit jemandem zusammen bin, der kräftig isst, esse ich meistens zuviel

Bei den üblichen Nahrungsmitteln kenne ich ungefähr den Kaloriengehalt

Wenn ich mal mit dem Essen begonnen habe, kann ich manchmal nicht mehr aufhören.

Mir fällt es nicht schwer Essensreste einfach übrig zulassen.

Zu den üblichen Essenszeiten bekomme ich automatisch Hunger.

Wenn ich während einer Diät ,„ündige“, dann halte ich mich anschließend beim Essen zurück, um wieder auszugleichen.

Wenn andere in meiner Gegenwart essen, möchte ich mitessen.

Wenn ich Kummer habe, esse ich oft zuviel.

Essen macht mir viel Spaß, und ich will es mir nicht durch Kalorienzählen oder Gewichtskontrollen verderben.

Wenn ich leckere Dinge sehe, kriege ich häufig solchen Appetit, dass ich sie sofort esse

Häufig höre ich auf zu essen, obwohl ich noch gar nicht richtig satt bin.

Mein Magen kommt mir oft wie ein ,Fass ohne Boden“ vor.

In den letzten zehn Jahren hat sich mein Gewicht so gut wie nicht verändert.

Da ich ständig Appetit habe, fällt es mir schwer mit dem Essen aufzuhören, bevor der Teller leer ist.

Wenn ich mich einsam fühle, tröste ich mich mit Essen.

Ich halte mich beim Essen bewusst zurück, um nicht zuzunehmen.

Spätabends oder in der Nacht bekomme ich manchmal großen Hunger. 
Ich esse alles was ich möchte und wann ich es will.

Ich esse eher langsam, ohne groß darüber nachzudenken.

Ich zähle Kalorien um mein Gewicht unter Kontrolle zu halten.

Bestimmte Nahrungsmittel meide ich weil sie dick machen.

Ich könnte zu jeder Tageszeit essen, da ich ständig Appetit habe.

Ich achte sehr auf meine Figur.

Wenn ich während einer Diät etwas „Unerlaubtes“ esse, dann denke ich oft ,,Jetzt ist es auch egal" und dann lange ich erst recht zu.

5. Bei den folgenden Fragen bitte ankreuzen, was am ehesten auf Sie zutrifft:

Haben Sie auch zwischen den Essenszeiten Hungergefühle?

Wenn Sie zuviel gegessen haben, bringen Sie Gewissensbisse dazu, sich eher zurückzuhalten?

Wäre es schwierig für Sie, eine Mahlzeit mittendrin zu unterbrechen und dann vier Stunden lang nichts mehr zu essen?

Achten Sie darauf, dass Sie keinen Vorrat an verlockenden Lebensmitteln haben?

Kaufen Sie häufig kalorienarme Lebensmittel?

Essen Sie kontrolliert, wenn Sie mit anderen zusammen sind, und lassen Sie sich dann gehen, wenn Sie allein sind?

Essen Sie bewusst langsam, um Ihre Nahrungsaufnahme einzuschränken?

Wie oft verzichten Sie auf Nachtisch weil Sie keinen Appetit mehr haben?

Wie häufig kommt es vor, dass Sie bewusst weniger essen, als Sie gerne möchten?

Kommt es vor, dass Sie Essen verschlingen, obwohl Sie nicht hungrig sind?

\begin{tabular}{|c|c|c|c|}
\hline immer & oft & selten & nie \\
\hline$Q$ & 8 & 6 & 0 \\
\hline 0 & 9 & 0 & 6 \\
\hline 0 & 6 & 0 & 9 \\
\hline 0 & 0 & 8 & 6 \\
\hline 0 & 6 & 8 & 0 \\
\hline 6 & 8 & 9 & (6) \\
\hline 0 & 6 & 6 & 8 \\
\hline 6 & $d$ & 0 & 0 \\
\hline$\varphi$ & c) & 6 & 0 \\
\hline 6 & 5 & 6 & 6 \\
\hline
\end{tabular}

\title{
6. Treffen diese Aussagen auf Ihr Essverhalten zu?
}

\begin{abstract}
„Morgens halte ich noch Diät, aber durch die
Tagesereignisse bin ich am Abend so weit, dass ich wieder esse, wäs ich will. Ich nehme mir dann vor, ab morgen standhaft zu bleiben."

Würden Sie Ihre Lebensweise ändern, wenn Sie eine Gewichtsveränderung von fünf Pfund (2,5 Kilogramm) feststellten?
\end{abstract}

Achten Sie darauf, was Sie essen?

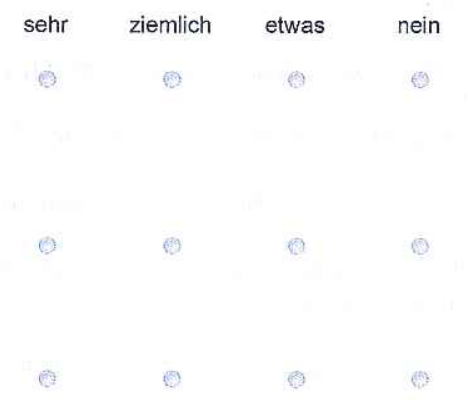




\section{Anhang 7. Kreuzen Sie an, was auf Ihr Essverhalten zutrifft (nur eine Antwort):}
Ich esse was ich will, wann ich will.
Ich esse gewöhnlich was ich will, wann ich will.
Ich esse oft was ich will, wann ich will.
Ich halte mich ebenso oft zurück wie ich nachgebe.
Ich halte mich gewöhnlich zurück, gebe selten nach.
Ich halte mich durchweg zurück, gebe nicht nach.

8. Wie häufig haben Sie bereits Schlankheitsdiäten gemacht?

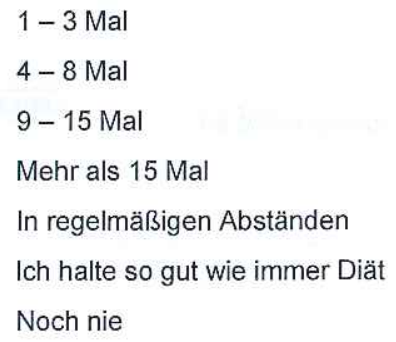

9. Für die folgenden Fragen bitte Zustimmung oder Ablehnung ankreuzen:

Wenn ich an einem Tag etwas mehr esse, gleiche ich es am nächsten Tag wieder aus.

Ich esse Lebensmittel, die schlank machen, auch wenn sie mir nicht besonders schmecken.

Zum Abnehmen wäre mir eine Diät zu langweilig.

Obwohl ich sehr auf meine Figur achte, kann ich die Vielfalt der Lebensmittel genießen.

Ich lasse lieber eine Mahlzeit ausfallen, als nach der Hälfte aufzuhören.

Bei mir wechseln sich Phasen, in denen ich streng Diät halte mit Zeiten ab, bei denen ich esse, was und wieviel ich will.

Manchmal lasse ich Mahlzeiten ausfallen, um nicht zuzunehmen.

Es gibt Lebensmittel, die ich grundsätzlich nicht esse, obwohl ich sie mag.

Beim Abnehmen versuche ich mich möglichst an einen Plan zu halten.

Üblicherweise bevorzuge ich leichte Lebensmittel, die nicht dick machen.

Wenn ich bei einer Mahlzeit zuviel esse, esse ich bei der nächsten weniger.

Ohne Diätplan weiß ich gar nicht, wie ich mein Gewicht in den Griff bekommen kann.

Bei einer Diät zählt für mich der schnelle Erfolg.

10. Kreuzen Sie an, was auf Ihr Essverhalten zutrifft (nur eine Antwort):

Essen Sie bei Mahlzeiten bewusst weniger, als sie eigentlich möchten? 
Seite 08

11. Abschließend hätten wir noch ein paar Fragen zu ihrer Person Sie sind...
männlich
weiblich

12. Wie alt sind Sie?

Ich bin Jahre alt.

13. Bitte geben Sie hier ihre Körpergröße und ihr aktuelles Körpergewicht an

Ich bin

Ich wiege

Bei meiner

momentanen

Körpergröße war das

höchste Gewicht, das

ich jemals hatte

14. Für Frauen

m (z.B. $1,70 \mathrm{~m})$ groß.

$\mathrm{kg}$ (z.B. $65,0 \mathrm{~kg})$.

$\mathrm{kg}$

Ist Ihre Regelblutung während der letzten drei bis vier Monate ausgeblieben?

SD15

Wenn ja, wie viele

Regelblutungen sind

ausgeblieben?

15. Was ist Ihre Hauptsportart

SL06 비

(diese Sportart für die Sie die meiste Zeit aufwenden, bzw. jene Sportart, die Ihnen die Liebste ist)

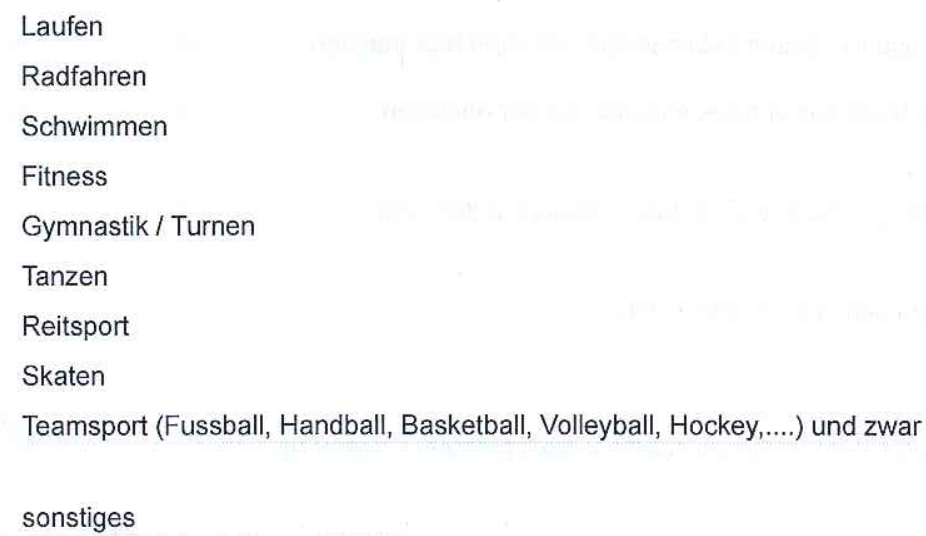


16. Nehmen Sie an Wettkämpfen teil?

Ich treibe Stunden Sport pro Woche.

18. Seit wie vielen Jahre betreiben Sie Ausdauersport? Bitte tragen Sie die Angabe in Jahren ein

Ich treibe seit Jahren Ausdauersport

19. Wie wichtig ist Ihnen die Ausübung ihres Sports verglichen mit anderen Tätigkeiten SLOIIIIIIII Leben?

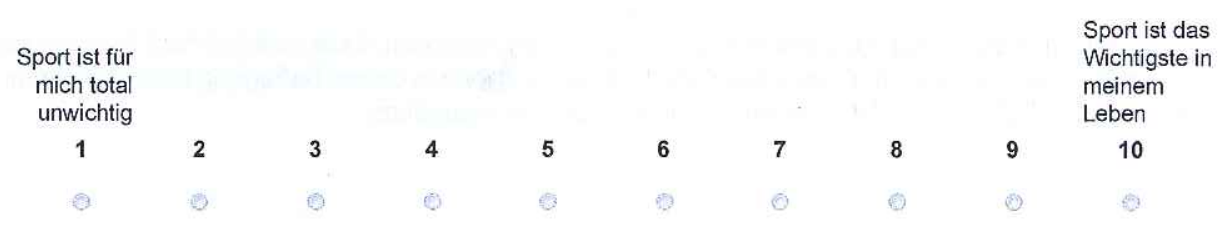

20. Schätzen Sie bitte so genau wie möglich, wie viel Sie pro Tag ans Essen denken.

SD18

$\%$ meiner Gedanken pro Tag drehen sich um Essen.

Wie stark beschäftigen Sie diese Gedanken?
Wie stark schränken Sie die Gedanken in Ihrem
Alltag ein?

21. Wurde bei Ihnen eine Erkrankung diagnostiziert?

Wenn ja, geben Sie die Diagnose/n bitte an 
22. Haben Sie zusätzliche Anmerkungen oder Informationen zu Ihrer Person, die Sie für die Studie als wichtig erachten?

Dann notieren Sie diese gerne im folgenden Textfeld.

Seite 09

23. Wenn Sie an der Verlosung von unserem kleinen monetären Dankeschön (3 Stück à GE $€$-Amazon-Gutscheine) teilnehmen möchten, geben Sie bitte Ihre E-Mail-Adresse an. Diese wird getrennt von allen anderen Angaben gespeichert, so dass keinerlei Hinweise auf die Befragung verknüpft werden.

Für die Teilnahme am Gewinnspiel notieren Sie bitte hier Ihre Mailadresse

[. Ich will am Gewinnspiel teilnehmen. Ich bin damit einverstanden, dass meine E-Mail-Adresse bis zur Ziehung der Gewinner gespeichert wird. Meine Angaben in dieser Befragung bleiben weiterhin anonym, meine E-Mail-Adresse wird nicht an Dritte weitergegeben. 
Letzte Seite

\section{Vielen Dank für Ihre Teilnahme!}

Wir möchten uns ganz herzlich für Ihre Mithilfe bedanken.

Die Daten werden vertraulich behandelt und im Rahmen meiner Doktorarbeit anonymisiert ausgewertet. Diese Arbeit behandelt den Themenschwerpunkt "problematisches Sport- und Essverhalten". Bei Rückfragen können Sie gerne mit mir Kontakt aufnehmen: carolin.hauck@med.uni-goettingen.de Ihre Antworten wurden gespeichert, Sie können das Browser-Fenster nun schließen.

\section{Einladung zum SoSci Panel}

Liebe Teilnehmerin, lieber Teilnehmer,

das nicht-kommerzielle SoSci Panel würde Sie gerne zu interessanten und hochwertigen wissenschaftlichen Onlinebefragungen einladen.

Wir würden uns sehr freuen, wenn Sie die wissenschaftliche Forschung unterstützen und unten Ihre E-Mail-Adresse angeben. An diese Adresse senden wir dann zunächst eine Bestätigungsmail. Wenn Sie Ihre Teilnahme am SoSci Panel bestätigen, senden wir Ihnen pro Jahr maximal 4 Einladungen per E-Mail. Sie gehen keine Verpflichung ein und können die Teilnahme jederzeit mit drei Klicks beenden.

E-Mail:

Am Panel teilnehmen

Das SoSci Panel hat seinen Sitz in Deutschland (München) und ist damit an das strenge deutsche Datenschutzrecht gebunden. Wir achten Ihre Privatsphäre und Anonymität, denn wir sind auf Sie angewiesen. Und selbstverständlich geben wir Ihre E-Mail-Adresse nicht an Dritte weiter.

Der Fragebogen, den Sie gerade ausgefüllt haben, wurde gespeichert. Sie können das Browserfenster selbstverständlich auch schließen, ohne am SoSci Panel teilzunehmen.

Dr. Melanie Schipfer, Martin-Luther-Universität Halle-Wittenberg

M.Sc. Carolin Hauck, Georg-August-Universität Göttingen 
Anhang

\section{Genussstudie}




\section{Fragebogen „Genussstudie“ \\ 27.06.2017 Deutsch}

Personendaten:

- Alter, Geschlecht, Stadt/Land, Bildungsniveau, Beziehungsstatus, Familiengröße, Berufsstatus (auch Vollzeit, Halbtags) Lieferando

- Körpergröße, Körpergewicht (ganz zum Schluss) Frage 26 von Lieferando

STICHPROBE \& QUOTIERUNG siehe QUOTA

D1.

Sind Sie...?

Männlich

Weiblich

D2.

Und wie alt sind Sie?

Jahre

\begin{tabular}{|l|l|}
\hline Younger than 18 years & Close interview \\
\hline $18-29$ & \\
\hline $30-39$ & \\
\hline $40-49$ & \\
\hline $50-59$ & \\
\hline $60-69$ & \\
\hline 70 and older & \\
\hline
\end{tabular}

D3.

In welchem Bundesland leben Sie?

\begin{tabular}{|l|l|}
\hline Schleswig-Holstein & 1 \\
\hline Hamburg & 2 \\
\hline Niedersachsen & 3 \\
\hline Bremen & 4 \\
\hline Nordrhein-Westfalen & 5 \\
\hline Hessen & 6 \\
\hline Rheinland-Pfalz & 7 \\
\hline Baden-Württemberg & 8 \\
\hline Bayern & 9 \\
\hline
\end{tabular}




\begin{tabular}{|l|l|}
\hline Saarland & 10 \\
\hline Berlin & 11 \\
\hline Brandenburg & 12 \\
\hline Mecklenburg-Vorpommern & 13 \\
\hline Sachsen & 14 \\
\hline Sachsen-Anhalt & 15 \\
\hline Thüringen & 16 \\
\hline
\end{tabular}

D4.

Bitte geben Sie uns Ihre Postleitzahl an (5-stellig).

Open field for 5 digits

D5.

Und welches ist Ihr letzter Schulabschluss?

\begin{tabular}{|l|c|}
\hline Grund-/Hauptschule ohne abgeschlossene Lehre & 1 \\
\hline Grund-/Hauptschule mit abgeschlossener Lehre & 2 \\
\hline Weiterführende Schule ohne Abitur/ Hochschulreife & 3 \\
\hline Weiterführende Schule mit Abitur/ Hochschulreife & 4 \\
\hline Universität/ Hochschule & 5 \\
\hline Keines der oben genannten trifft zu & 6 \\
\hline
\end{tabular}

Fragen des IfE aus anderen bzw. ergänzenden Kontexten in blau

F6. Wie viele Personen leben ständig in Ihrem Haushalt, Sie selbst eingeschlossen? Bitte nur eine Antwort angeben

\begin{tabular}{|l|}
\hline 1 \\
\hline 2 \\
\hline 3 \\
\hline 4 \\
\hline 5 \\
\hline 6 \\
\hline 7 oder mehr \\
\hline
\end{tabular}




\section{$<$ Themenblock 1 Ernährung und Genuss>}

Fragen 1-5 von Lieferando

Fragen 6-10 von Lieferando

1. In den letzten zwei Wochen ...

Bitte kreuzen Sie jeweils eine Antwortoption an.

\begin{tabular}{|l|l|l|l|l|l|l|}
\hline Randomise items & $\begin{array}{l}\text { Die } \\
\text { ganze } \\
\text { Zeit }\end{array}$ & Meistens & $\begin{array}{l}\text { Etwas } \\
\text { mehr } \\
\text { als die } \\
\text { Hälfte } \\
\text { der Zeit }\end{array}$ & $\begin{array}{l}\text { Etwas } \\
\text { weniger } \\
\text { als die } \\
\text { Hälfte } \\
\text { der Zeit }\end{array}$ & $\begin{array}{l}\text { Ab } \\
\text { und } \\
\text { zu }\end{array}$ & $\begin{array}{l}\text { Zu } \\
\text { keinem } \\
\text { Zeitpunkt }\end{array}$ \\
\hline$\ldots$ war ich froh und guter & & & & & \\
Laune. & & & & & & \\
\hline $\begin{array}{l}\ldots \text { habe ich mich ruhig und } \\
\text { entspannt gefühlt. }\end{array}$ & & & & & \\
\hline $\begin{array}{l}\ldots \text { habe ich mich energisch und } \\
\text { aktiv gefühlt. }\end{array}$ & & & & & & \\
\hline $\begin{array}{l}\text { A. habe ich mich beim } \\
\text { Aufwachen frisch und } \\
\text { ausgeruht gefühlt. }\end{array}$ & & & & & & \\
\hline $\begin{array}{l}\ldots \text { war mein Alltag voller Dinge } \\
\text { die mich interessieren. }\end{array}$ & & & & & & \\
\hline
\end{tabular}

WHO (Fünf) - FRAGEBOGEN ZUM WOHLBEFINDEN (Version 1998). Psychiatric Research Unit, WHO Collaborating Center for Mental Health, Frederiksborg General Hospital, DK-3400 Hillerød

2. Bitte kreuzen Sie bei den folgenden 5 Aussagen an, inwieweit Sie diesen zustimmen.

\begin{tabular}{|l|l|l|l|l|l|l|l|}
\hline Randomise items & $\begin{array}{l}\text { Stimme } \\
\text { völlig } \\
\text { zu }\end{array}$ & $\begin{array}{l}\text { Stimme } \\
\text { zu }\end{array}$ & $\begin{array}{l}\text { Stimme } \\
\text { eher zu }\end{array}$ & $\begin{array}{l}\text { Weder/ } \\
\text { noch }\end{array}$ & $\begin{array}{l}\text { Stimme } \\
\text { eher } \\
\text { nicht zu }\end{array}$ & $\begin{array}{l}\text { Stimme } \\
\text { nicht zu }\end{array}$ & $\begin{array}{l}\text { Stimme } \\
\text { überhaupt } \\
\text { nicht zu }\end{array}$ \\
\hline $\begin{array}{l}\text { In den meisten Bereichen } \\
\text { entspricht } \\
\text { mein Leben meinen } \\
\text { Idealvorstellungen. }\end{array}$ & & & & & & & \\
\hline $\begin{array}{l}\text { Meine Lebensbedingungen } \\
\text { sind } \\
\text { ausgezeichnet. }\end{array}$ & & & & & & & \\
\hline $\begin{array}{l}\text { Ich bin mit meinem Leben } \\
\text { zufrieden. }\end{array}$ & & & & & & & \\
\hline $\begin{array}{l}\text { Bisher habe ich die } \\
\text { wesentlichen } \\
\text { Dinge erreicht, die ich mir } \\
\text { für mein Leben wünsche. }\end{array}$ & & & & & & & \\
\hline $\begin{array}{l}\text { Wenn ich mein Leben noch } \\
\text { einmal leben könnte, würde } \\
\text { ich } \\
\text { kaum etwas ändern. }\end{array}$ & & & & & & & \\
\hline
\end{tabular}


SWLS-5: Glaesmer H, Grande G, Braehler E, Roth M (2011). The German Version of the Satisfaction with Life Scale - Psychometric Properties and Population based norms. European Journal of

Psychological Assessment, 27(2), 127-132.

3. Im Folgenden möchten wir mit Ihnen über Essen sprechen. Was ist für Sie besonders wichtig, um ein Essen so richtig genießen zu können?

Bitte notieren Sie was Ihnen auf Anhieb dazu einfällt:

CAl: open

(Berichtsband 1991, S.8)

4. Was ist Ihr Lieblingsgericht?

CAl: open

(Berichtsband 1991, S.21)

5. Wurden Sie in Ihrer Kindheit mit Essen getröstet?

Bitte kreuzen Sie die zutreffende Häufigkeit an.

\begin{tabular}{|l|l|l|l|l|l|}
\hline Sehr häufig & Häufig & Manchmal & Selten & Nie & Ich erinnere mich nicht \\
\hline
\end{tabular}

6. Wie häufig nutzen Sie Essen um Ihre Stimmung/Laune zu beeinflussen? Bitte geben Sie die Häufigkeit an.

\begin{tabular}{|l|l|l|l|l|}
\hline Täglich & $2-3$ & Einmal pro & Einmal pro & Selten oder \\
& Mal/Woche & Woche & Monat & Nie \\
\hline
\end{tabular}

Frage 22 von Lieferando

7. Welche Aussage beschreibt am besten den Zusammenhang zwischen Essen und Stimmung/Laune bei lhnen? Frage 13 von Lieferando

Bitte eine Antwort ankreuzen. <Themenblock 1 Ernährung und Genuss>

Essen beeinflusst meine Stimmung/Laune immer. 
8. Essen Sie um Ihre Stimmung/Laune zu verbessern, wenn Sie ... Bitte kreuzen Sie jeweils eine Antwort an.

\begin{tabular}{|l|l|l|l|}
\hline & Nein & Ja & $\begin{array}{l}\text { Wenn ja, welche Lebensmittel essen Sie } \\
\text { (CAl: open): }\end{array}$ \\
\hline Liebeskummer haben? & & & \\
\hline sich einsam fühlen? & & & \\
\hline gestresst sind? & & & \\
\hline gelangweilt sind? & & & \\
\hline
\end{tabular}

Frage 14-21 von Lieferando

9. Welches ist /hr Lieblings-Lebensmittel/ /hre Lieblingsspeise um Ihre Stimmung/Laune zu beeinflussen? Frage 23 von Lieferando

Hier können Sie verschiedene Lebensmittel-auflisten oder in bestimmtes angeben < Themenblock 1 Ernährung und Genuss>:

\section{Nun geht es um Dinge, die Sie gerne tun.}

Bitte geben Sie zu jeder der folgenden Punkte an, inwieweit sie Genuss für Sie bedeuten oder nicht.

Nutzen Sie dazu bitte eine Skala von 1 = gar kein Genuss bis 5 = sehr hoher

Genuss.

Mit den Werten dazwischen können Sie Ihre Meinung abstufen.

Bitte bringen Sie die 24 Verhaltensweisen in eine Rangfolge, aufsteigend nach Genuss ( 1 = geringster Genuss, 24 = höchster Genuss) (Berichtsband 1991, S.7).

CAl: Skala

CAl: show in grid, randomise items, show scale again after 12 items

\begin{tabular}{|l|l|l|l|l|}
\hline 1 & 2 & 3 & 4 & 5 \\
\hline Gar kein Genuss & & & & Sehr hoher Genuss \\
\hline
\end{tabular}

Verhaltensweise

1. Fernsehen

2. Zeit mit Freunden verbringen/Freunde treffen

3. Mich pflegen, etwas für meinen Körper tun

4. Urlaub machen

5. Zeit mit der Familie verbringen

6. Im Restaurant essen

7. Etwas trinken gehen

8. Zuhause einen Drink nehmen

9. Entspannen/Ausruhen/Schlafen

10. Feste mit Freunden/Bekannten feiern

11. Flirten/Liebe/Sexualität

12. Hobbies aktiv betreiben 


\begin{tabular}{l|l} 
13. Arbeiten, um beruflich Erfolg zu haben & \\
\hline 14. Das (all)tägliche Essen zuhause & \\
15. Bücher/Zeitungen/Zeitschriften online/gedruckt lesen & \\
16. Rauchen & \\
17. Sport treiben, sich aktiv bewegen & \\
18. Ausgehen (Tanzen, Disco, Restaurant, Kneipe, etc.) & \\
19. Videospiele/PC-Spiele spielen & \\
20. Soziale Medien zur Kommunikation nutzen, chatten, bloggen & \\
21. Kulturelle Angebote nutzen & \\
22. Zeit draußen verbringen & \\
\hline 23. Ins Kino gehen & \\
\hline 24. Zuhause toll essen & \\
\hline
\end{tabular}

11.

Bitte geben Sie für diese Aspekte beim Essen an, wie wichtig diese für Sie sind. Nutzen Sie auch hier bitte eine Skala von 1 = überhaupt nicht wichtig bis 5 = äußert wichtig. Mit den Werten dazwischen können Sie Ihre Meinung abstufen.

CAl: Skala

CAl: show in grid, randomise items

\begin{tabular}{|l|l|l|l|l|}
\hline 1 & 2 & 3 & 4 & 5 \\
\hline $\begin{array}{l}\text { Überhaupt nicht } \\
\text { wichtig }\end{array}$ & & & & Äußerst wichtig \\
\hline
\end{tabular}

\begin{tabular}{l|l|}
\hline Eigenschaft & \\
\hline$\ldots$ dass es gut schmeckt. & \\
\hline$\ldots$ dass es günstig ist. & \\
\hline$\ldots$ dass man es sich verdient hat & \\
\hline$\ldots$ ein Besonderer Anlass um zu essen & \\
\hline$\ldots$ die gute Qualität der Zutaten & \\
\hline$\ldots$ die angenehme Stimmung & \\
\hline$\ldots$ die Herkunft der Lebensmittel & \\
\hline
\end{tabular}

12. Zu welcher Tageszeit Essen Sie am häufigsten mit Genuss?

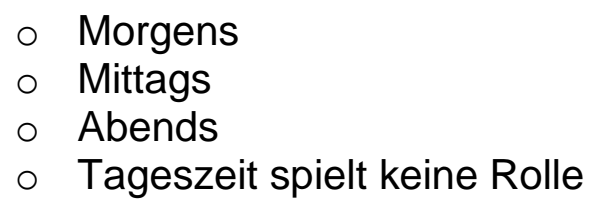

(Berichtsband 1991, S.9) 
13. An welchem Wochentag Essen Sie am häufigsten mit Genuss?

○ Freitags

- Samstags

- Sonntags

- Nur zu besonderen Festen (Geburtstag, etc.)

- Nur zu besonderen Feiertagen (Weihnachten, etc.)

- Tag spielt keine Rolle

(Berichtsband 1991, S.8)

14. Wo Essen Sie am Häufigsten mit Genuss?

CAl: randomise items except last

- Restaurant, Gasthaus

- Kantine, Mensa

- Unterwegs

- Zu Hause

- Bei Freunden/Verwandten zu Hause

- Ort spielt keine Rolle

(Berichtsband 1991, S.8)

15. Mit wem essen Sie meistens?

Bitte wählen Sie eine Antwort pro Tageszeit.

CAl: one answer per answer bloc (morgens, mittags, abends)

a.) morgens

b.) mittags

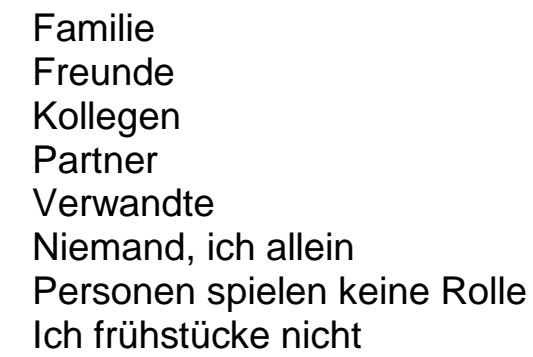
$\circ$ Familie
- Freunde
- Kollegen
- Partner
- Verwandte
- Niemand, ich allein
- Personen spielen keine Rolle Ich esse mittags nicht

c.) abends

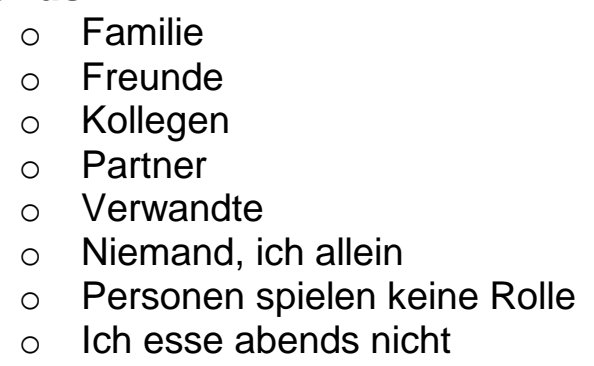


16. Stufen Sie sich bitte selbst ein.

Ich bin .... :

- wirklich kein Genießer.

- kaum ein Genießer.

- eher kein Genießer.

- wohl eher ein Genießer.

- ein Genießer.

- ein großer Genießer.

(Berichtsband 1991, S.10)

50.

Wenn ich etwas Leckeres esse, dann ...

\begin{tabular}{|l|l|l|l|l|}
\hline 5 & 4 & 3 & 2 & 1 \\
\hline $\begin{array}{l}\text { genieße ich es } \\
\text { voll und ganz }\end{array}$ & & & & $\begin{array}{l}\text { habe ich ein schlechtes } \\
\text { Gewissen }\end{array}$ \\
\hline
\end{tabular}

\section{Welche Ernährungsweise verfolgen Sie derzeit?}

Bitte kreuzen Sie eine Ernährungsweise an.

CAl: Single punch, randomise items except last 2

\begin{tabular}{|l|}
\hline Vegetarisch \\
\hline Flexitarisch \\
\hline Lakto-vegetarisch \\
\hline Ovo-vegetarisch \\
\hline Ovo-lakto-vegetarisch \\
\hline Pesco-vegetarisch \\
\hline Rohkost/Raw Food \\
\hline Vegan \\
\hline Zuckerfrei \\
\hline Glutenfrei \\
\hline Laktosefrei \\
\hline Low fat \\
\hline Low carb \\
\hline Clean eating \\
\hline Fruktarisch \\
\hline Vollwertkost \\
\hline Makrobiotisch \\
\hline Ayurveda \\
\hline Kosher \\
\hline Halal \\
\hline Hinduistisch \\
\hline Keinerlei besondere Ernährungsweise/Diät \\
\hline Sonstige (CAl: open-ended) \\
\hline
\end{tabular}

Frage 12 von Lieferando 
<Themenblock 2 Trends over Time sowie einzelne weitere Aspekte> Ein Teil der Studie bekommt das Wort „Essen“, der andere Teil beantwortet dieselbe Frage, jedoch steht hier das Wort „Ernährung“ in der Frage 50/50 Split (per Random zugeordnet ) $\rightarrow$ wie verhält sich das dann mit einem „,boost“? Wie viele Teilnehmer müssten wir dann hierzu befragen, damit die Antworten auswertbar sind?

CAl: split questions in 4 test cells cell $1: 17.1 a+17.2 a+32 a$

cell $2: 17.1 b+17.2 b+32 a$

cell $3: 17.1 a+17.2 a+32 b$

cell $4: 17.1 b+17.2 b+32 b$

CAl: $50 \%$ of sample for $17.1 a \& 17.2 a, 50 \%$ for $17.1 b \& 17.2 b$

17.1a

In dieser Befragung geht es um ein Thema, das alle angeht und wozu alle Ihre Erfahrungen und Meinungen haben. Es geht um Ernährung, Essen, Kochen, Lebensmittel, Rezepte, Restaurants.

Worauf legen Sie bei Ihrem Essen den größten Wert?

CAI: Randomise items

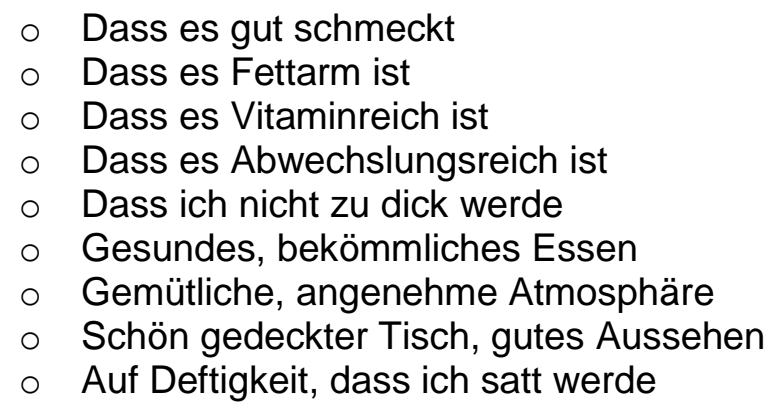

(Berichtsband 1991, S.11, Fragenkatalog 1995 Frage 1, S. 31 ff).

17.1b

In dieser Befragung geht es um ein Thema, das alle angeht und wozu alle Ihre Erfahrungen und Meinungen haben. Es geht um Ernährung, Essen, Kochen, Lebensmittel, Rezepte, Restaurants.

Worauf legen Sie bei Ihrer Ernährung den größten Wert?

CAI: Randomise items

- Dass es gut schmeckt

- Dass es Fettarm ist

- Dass es Vitaminreich ist

- Dass es Abwechslungsreich ist

- Dass ich nicht zu dick werde

- Gesundes, bekömmliches Essen

- Gemütliche, angenehme Atmosphäre

- Schön gedeckter Tisch, gutes Aussehen

- Auf Deftigkeit, dass ich satt werde

(Berichtsband 1991, S.11, Fragenkatalog 1995 Frage 1, S. $31 \mathrm{ff}$ ). 
$17.2 \mathrm{a}$

Interessieren Sie sich für Fragen zum Essen oder haben Sie dafür eher kein Interesse?

Eine 1 bedeutet „kein Interesse“ und eine 6 bedeutet „starkes Interesse“.

\begin{tabular}{|l|l|l|l|l|l|}
\hline $\begin{array}{l}\text { Kein } \\
\text { Interesse }\end{array}$ & & & & & Starkes Interesse \\
\hline 1 & 2 & 3 & 4 & 5 & 6 \\
\hline
\end{tabular}

(Fragenkatalog 1995 Frage 2, S. 53 ff).

$17.2 b$

Interessieren Sie sich für Fragen der Ernährung oder haben Sie dafür eher kein Interesse?

Eine 1 bedeutet „kein Interesse“ und eine 6 bedeutet „starkes Interesse“.

\begin{tabular}{|l|l|l|l|l|l|}
\hline $\begin{array}{l}\text { Kein } \\
\text { Interesse }\end{array}$ & & & & & Starkes Interesse \\
\hline 1 & 2 & 3 & 4 & 5 & 6 \\
\hline
\end{tabular}

(Fragenkatalog 1995 Frage 2, S. 53 ff).

18. Wie gut können Sie Ihrer Meinung nach Kochen?

- Sehr gut

- Gut

- Durchschnittlich

- Ein bisschen

- Wenig

- Gar nicht

(Fragenkatalog 1995, Berichtsband S. 8). 
19. Nun stellen wir Ihnen ein paar Fragen zum Kochen:

a) Wie häufig kochen Sie selbst, bereiten also warme Mahlzeiten zu?

○ Täglich oder fast täglich

- Mehrfach in der Woche

- Mehrmals im Monat

- Eigentlich nur am Wochenende

- Nur gelegentlich

- Eher selten

- Eigentlich nie

(Fragenkatalog 1995 Frage 7, S. $75 \mathrm{ff}$

b) Für wie viele Personen kochen Sie normalerweise, Sie selbst eingerechnet? Bitte geben Sie die zutreffende Zahl an: CAl: allow for 2 digits, from 1-99

(Fragenkatalog 1995 Frage 8, S. 77 ff).

c) Ist Kochen für Sie eher eine lästige Pflicht oder ist Kochen für Sie eher mit Spaß verbunden? Sagen Sie bitte zunächst, wie das an normalen Werktagen ist, also das Wochenende ausgenommen.

... immer oder fast immer lästige Pflicht

... überwiegend lästige Pflicht

... unterschiedlich von Fall zu Fall

... Spaß überwiegt

... macht mir immer oder fast immer Spaß

(Fragenkatalog 1995 Frage 10a, S. 85 ff).

d) Und jetzt sagen Sie bitte, wie Sie das Kochen am Wochenende einschätzen.

○ .... immer oder fast immer lästige Pflicht

$\circ \quad$... überwiegend lästige Pflicht

○ ... unterschiedlich von Fall zu Fall

- ... Spaß überwiegt

- ... macht mir immer oder fast immer Spaß

(Fragenkatalog 1995 Frage 10b, S. 87 ff).

20. Wer ist meist Küchenchef? / Wer ist meistens für das Kochen verantwortlich?

- Ich selbst

- Ich und andere (Partner, Familie, Mitbewohner)

- Ich bin eher Beikoch

- Ich leiste Hilfstätigkeiten

- Ich koche nicht

(So is(s)t Deutschland, 2011, S. 44). 
21. Kaufen Sie selbst häufig Lebensmittel ein oder haben Sie damit wenig oder nichts zu tun?

○ Ich kaufe täglich oder fast täglich ein

- Ich kaufe mehrmals in der Woche ein

- Ich kaufe ein bis zweimal in der Woche ein

- Ich mache vor allem den Großeinkauf

- Ich kaufe gelegentlich ein

- Ich kaufe selten oder überhaupt nicht ein

(Fragenkatalog 1995 Frage 20, S. 223 ff).

23. Woher haben Sie Ihre Kochkenntnisse?

Bitte wählen Sie alle zutreffenden Antworten aus.

CAI: multi-punch, randomise

- Mutter, Schwiegermutter und andere Verwandte

- Kochbücher

- Selbst beigebracht

- Freunde, Partner, Kollegen

- Kurse, Schule, Ausbildung, Beruf

- Internet, Youtube

- Fernsehen, Kochsendungen

- Zeitschriften

(Fragenkatalog 1995 Frage 11, S. 89 ff).

24. Haben Sie eine der folgenden Erkrankungen?

Bitte wählen Sie alle zutreffenden Antworten aus.

CAI: multi-punch except last answer, randomise except last answer

- Diabetes

- Bluthochdruck

- Fettstoffwechselstörung, hoher Cholesterinspiegel, hoher Triglyzeridspiegel

○ Nahrungsmittelunverträglichkeit, -allergie

- Allergie allgemein

- Herz-/Kreislauf-Erkrankung

- Übergewicht/Adipositas

- Osteoporose

- Essstörung

- Keine trifft zu

(Fragenkatalog 1995 Fragen 31-33, S. 293 ff + Zusatz lfE). 
25. Welches der nachfolgenden Gerichte haben Sie bereits selbst aus Grundzutaten bzw. rohen Ausgangswaren zubereitet?

(Die Zubereitung nach Kochbuch oder Rezept ist erlaubt, die Verwendung von Fertigsoßen bzw. Fertigmischungen nicht.)

Bitte wählen Sie alle zutreffenden Gerichte aus.

CAl: multi-punch, randomise, except for "Ich koche nicht“" always at the end and mutually exclusive

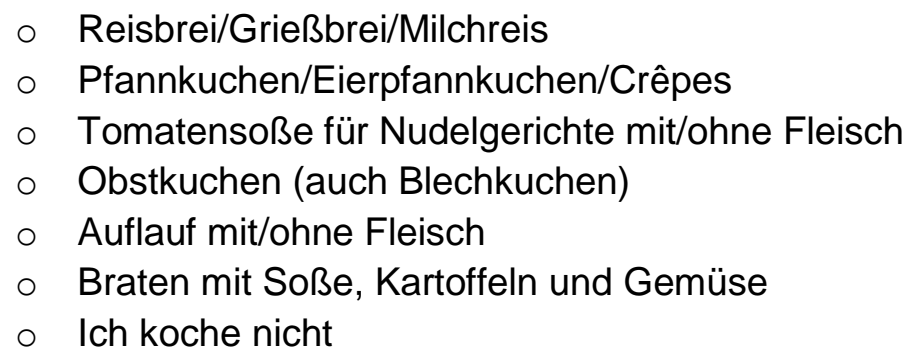

(Fragen aus NVS II 2008).

$<$ Themenblock 1 Ernährung und Genuss>

26. Wie schätzen Sie Ihre Ernährungsweise auf einer „Gesundheitsskala“ ein?

\begin{tabular}{|l|l|l|l|}
\hline Sehr gesund & Eher gesund & Eher ungesund & ungesund \\
\hline
\end{tabular}

27. Wie wichtig ist Ihnen gesunde Ernährung?

\begin{tabular}{|l|l|l|l|}
\hline sehr wichtig & eher wichtig & eher unwichtig & unwichtig \\
\hline
\end{tabular}

Frage 24 von Lieferando.

28. Um ein Essen so richtig genießen zu können, welchen Anteil hat dann das Essen/die Mahlzeit/das Produkt/das Lebensmittel selbst daran und welchen Anteil hat die Geselligkeit/die Atmosphäre daran?

\begin{tabular}{|l|l|l|}
\hline Anteil Essen selbst & $\begin{array}{l}\text { CAl: have a slider } \\
\text { between these two poles }\end{array}$ & $\begin{array}{l}\text { Anteil } \\
\text { Geselligkeit/Atmosphäre }\end{array}$ \\
\hline
\end{tabular}

Skala mit Schieberegler (100 \% Essen selbst - $100 \%$ Geselligkeit) 
$<$ Themenblock 2 Trends over Time sowie einzelne weitere Aspekte>

29. Gehören Sie einer Religion/Glaubensgemeinschaft an?

\begin{tabular}{|l|l|l|l|}
\hline Ja, evangelisch & Ja, katholisch & Ja, andere & Nein, keiner \\
\hline
\end{tabular}

30. Würden Sie sich als gläubigen Menschen bezeichnen?

\begin{tabular}{|l|l|l|l|}
\hline Ja & Eher ja & Eher nein & Nein \\
\hline
\end{tabular}

31. Welche Rolle spielt Familie in Ihrem Leben?

\begin{tabular}{|l|l|l|l|}
\hline $\begin{array}{l}\text { Familie spielt die } \\
\text { wichtigste Rolle in } \\
\text { meinem Leben }\end{array}$ & $\begin{array}{l}\text { Familie spielt } \\
\text { ein wichtige } \\
\text { Rolle in meinem } \\
\text { Leben }\end{array}$ & $\begin{array}{l}\text { Familie spielt } \\
\text { eine Rolle in } \\
\text { meinem Leben }\end{array}$ & $\begin{array}{l}\text { Familie spielt } \\
\text { kaum eine Rolle } \\
\text { in meinem Leben }\end{array}$ \\
\hline
\end{tabular}

CAl: $50 \%$ of sample for $32 a, 50 \%$ of sample for $32 b$

32a. Heute werden auch zusätzliche Steuern auf bestimmte Lebensmittel - z.B. solche mit hohem Zuckergehalt - diskutiert, um das Verbraucherverhalten zu lenken. Wie ist Ihre Meinung dazu?

\begin{tabular}{|l|l|l|}
\hline $\begin{array}{l}\text { Ich finde es richtig, wenn } \\
\text { zusätzliche Steuern auf } \\
\text { Lebensmittel mit einem } \\
\text { hohen Zuckergehalt } \\
\text { erhoben werden }\end{array}$ & $\begin{array}{l}\text { Ich bin in dieser Frage } \\
\text { unentschieden }\end{array}$ & $\begin{array}{l}\text { Das ist Sache des } \\
\text { Verbrauchers, da hat } \\
\text { sich der Staat nicht } \\
\text { einzumischen }\end{array}$ \\
\hline
\end{tabular}

32b. Heute werden auch zusätzliche Steuern auf bestimmte Lebensmittel - z.B. solche mit hohem Zuckergehalt - diskutiert, um das Verbraucherverhalten zu lenken. Wie ist Ihre Meinung dazu?

\begin{tabular}{|c|c|c|}
\hline $\begin{array}{l}\text { Ich finde es richtig, wenn } \\
\text { Schokolade, Bonbons, } \\
\text { Kekse, Limonaden, } \\
\text { Kuchen, Speiseeis, } \\
\text { Fruchtgummi, Lakritze } \\
\text { u.ä. Lebensmittel so } \\
\text { deutlich teurer werden }\end{array}$ & $\begin{array}{l}\text { Ich bin in dieser Frage } \\
\text { unentschieden }\end{array}$ & $\begin{array}{l}\text { Das ist Sache des } \\
\text { Verbrauchers, da hat } \\
\text { sich der Staat nicht } \\
\text { einzumischen }\end{array}$ \\
\hline
\end{tabular}


Im Folgenden möchten wir Ihnen noch ein paar allgemeine Fragen stellen

F4. Wie groß sind Sie?

Bitte geben Sie Ihre Größe in Zentimetern an. $\mathrm{cm}$

F5. Wieviel wiegen Sie?

Bitte geben Sie Ihr Gewicht in $\mathrm{kg}$ an. $\mathrm{kg}$

F7. Mit wem wohnen Sie derzeit zusammen? Bitte nur eine Antwort angeben

CAI: only if in F6 (Screener) answer 2 and more

Mit meinen Eltern

Mit meinem Partner/ Ehemann/ Ehefrau UND Kindern

Nur mit meinem Partner/ Ehemann/ Ehefrau OHNE Kinder

Mit meinen Kindern (OHNE Ehemann/Partner)

Mit Freunden/ WG in einer Wohnung/ Haus

F7b. Bitte nennen Sie uns Ihren Familienstatus.

Bitte nur eine Antwort angeben

\begin{tabular}{|l|}
\hline Verheiratet / Mit Partner zusammenlebend \\
\hline Alleinstehend \\
\hline Geschieden \\
\hline Verwitwet \\
\hline Keine Angabe \\
\hline
\end{tabular}

F8. Welcher der folgenden Kategorien lässt sich Ihr monatliches Haushaltsnettoeinkommen zuordnen?

Bitte nur eine Antwort angeben

1 Unter $1.400 €$

$21.400-2.500$

$32.501-3.500$

$43.501-5.000$

5 Über 5.000

6 Keine Angabe 
F9a Sind Sie zur Zeit berufstätig?

Bitte nur eine Antwort angeben

\begin{tabular}{|l|c|}
\hline ja, voll berufstätig & 1 \\
\hline ja, teilzeit, halbtags, stundenweise berufstätig & 2 \\
\hline nein, zur Zeit in der Ausbildung (Berufsausbildung, Schule, Studium) & 3 \\
\hline nein, zur Zeit nicht berufstätig (arbeitslos) & 4 \\
\hline nein, nicht berufstätig aber ich führe den Haushalt (Hausfrau/ Hausmann) & 5 \\
\hline nein, bereits in der Rente/ Pension/ Vorruhestand & 6 \\
\hline keine Angabe & 7 \\
\hline
\end{tabular}

F9b Welchem Beruf gehen Sie zurzeit nach?

Bitte nur eine Antwort angeben

CAI: only if in F9a answer 1- 2

\begin{tabular}{|l|l|}
\hline Inhaber von größeren Geschäften; Unternehmer; Großunternehmer & 1 \\
\hline Freier Beruf (Rechtsanwalt, Arzt) / selbständiger Akademiker & 2 \\
\hline selbst. Handwerksmeister / kleiner Gewerbetreibender/ Ladeninhaber & 3 \\
\hline Selbständiger Landwirt & 4 \\
\hline Höherer Beamter (Rat und mehr) & 5 \\
\hline Beamter der unteren, mittleren und gehobenen Laufbahn & 6 \\
\hline Leitender Angestellter & 7 \\
\hline Einfacher und mittlerer Angestellter & 8 \\
\hline Facharbeiter / unselbständiger Handwerker & 9 \\
\hline Ungelernter / angelernter Arbeiter & 10 \\
\hline
\end{tabular}


Lebenslauf

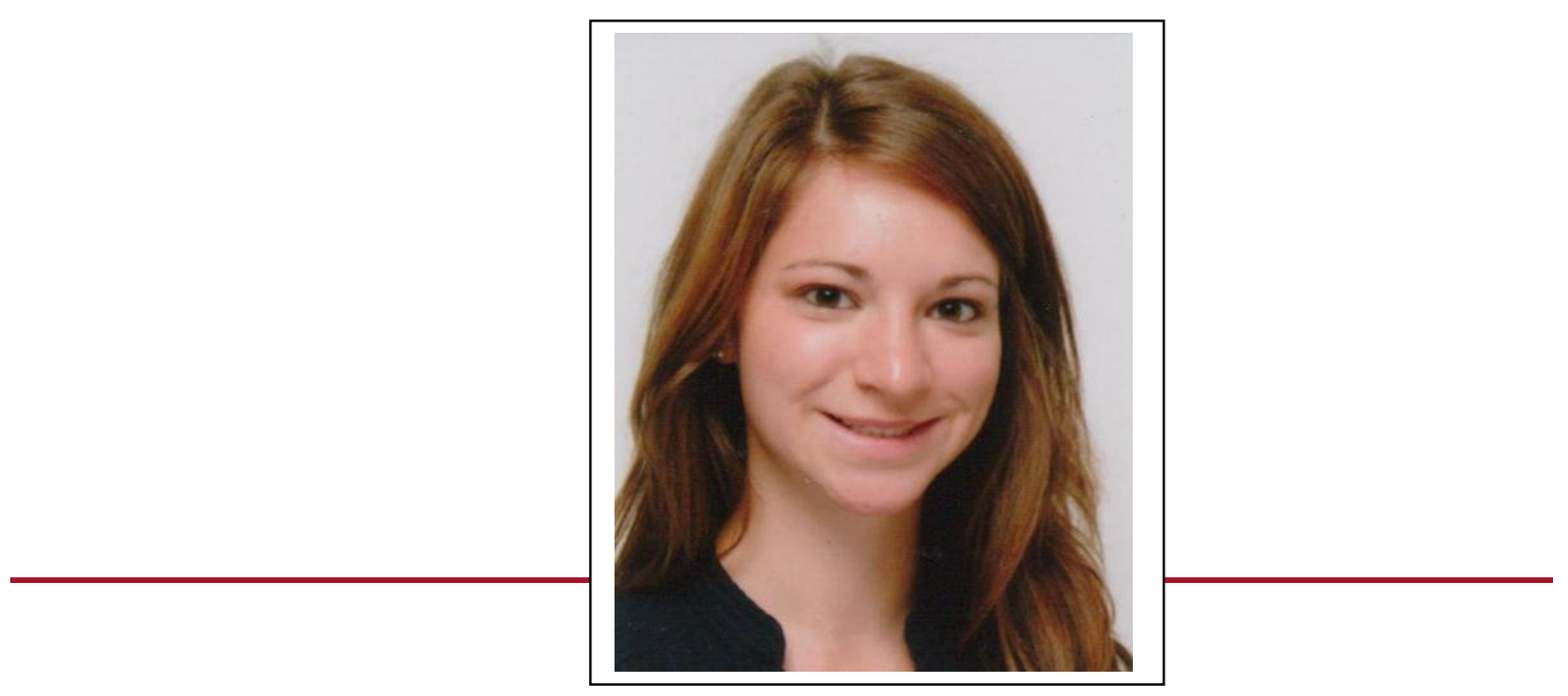

Carolin Hauck

Georg-August-University Goettingen

Institute for Nutrition and Psychology

Humboldtallee 32

37073 Goettingen

Telephone: +49551398964

Email: carolin.hauck@med.uni-goettingen.de 
Planned from June 2018

Jan 2015 - May 2018

Since Jul 2015

\section{Postdoctoral Researcher}

- at the Institute of Nutrition and Psychology, Georg-August University of Göttingen, Germany

\section{PhD student and Research Fellow}

- PhD Program for Agricultural Sciences in Göttingen (PAG) at the Faculty of Agricultural Sciences

- Research Fellow at the Institute of Nutrition and Psychology

- Teaching for medical, psychology and sports students

- Independent research on eating behavior of the German population, e.g. Food Addiction

- Organization of Conferences in Hannover; Aachen; Frankfurt; Potsdam

- Talks on Conferences

Personal Coach and Fitness Instructor

- Personal Training (sports, fitness, running, cycling, strength training) at Personal Sports, Göttingen

- Personal Coaching in nutrition

\section{Education}

Jan 2015 - May 2018

Oct 2012 - Jan 2015

Oct 2009 - July 2012

September 2002 - July 2009
Georg-August University of Göttingen, Germany

PhD Program for Agricultural Sciences in Göttingen (PAG) at the Faculty of Agricultural Sciences

University of Applied Sciences Münster, Germany Master of Science 'Nutrition and Health'

Justus-Liebig University of Gießen, Germany

Bachelor of Science 'Oecotrophology'

Regiomontanus-Gymnasium Haßfurt (high school), Germany

Related Experience

Since January 2017

Since Apr 2012

January - December 2014

January 2013 - January 2015
Talks/Workshops on nutrition; scientific additional employment Fitness Instructor with A license

Fitness Instructor, Run2 by Runners Point, Münster

Staff Member at Kochhaus Münster 


\section{Publications}

- Hauck C, Schipfer M, Ellrott T, Cook B (in preparation). Food Addiction, eating disorders and exercise dependence in German athletes.

- Hauck C, Schipfer M, Ellrott T, Cook B (under review). Food Addiction, exercise dependence and perfectionism in German athletes.

- Hauck C, Ellrott T (2017) Zusammenhänge zwischen Genuss und Übergewicht/Adipositas. Adipositas 2017; 11: 192-197

- Philipsborn PV; Hauck C; Gatzemeier J; Landsberg B; Holzapfel C (2017): Süßgetränke und Körpergewicht: Zusammenhänge und Interventionsmöglichkeiten. Adipositas 2017;11: 140145

- Hauck C, Ellrott T (2017) ,Food Addiction': addictive-like eating behavior. The current state of research with the Yale Food Addiction Scale. Ernahrungs Umschau Int 64(6): 102-110 DOI: 10.4455/eu.2017.023

- Hauck, C, Weiß, A, Orenstein, E, Meule, A, and Ellrott, T (2017). Prevalence of 'food addiction' as measured with the Yale Food Addiction Scale 2.0 in a representative German sample and its association with sex, age and weight categories. Obesity Facts https://doi.org/10.1159/000456013.

- Hauck C, Weiß A and Ellrott T (2016): Relationship between "food addiction", restrained eating behavior, mental health status and score of binge eating in a morbidly obese German sample. Adipositas (Schattauer), vol. 10, no. 4, pp. 215-220

- Hauck C (2016) Entwicklung eines Selbsttests zur Überprüfung des Hydratationsstatus von Ausdauersportlern. Ernährungs Umschau 1/2016, M11

- Hauck C (2015) Überprüfung des Hydratationsstatus von Ausdauersportlern - Entwicklung eines Selbsttests. Ernährung im Fokus 07-08|15, p. 202-205

\section{Lectures}

- Hauck C, Gutmann M (2017). Lecture at PFH Göttingen Germany.

- Hauck C, Hansen SL, Faustin V (since 2017) Healthy Campus Workshop - Psychologische, soziokulturelle und ethische Aspekte von Adipositas im Rahmen des Hochschulsports der Universität Göttingen

- Hauck C (since 2017). Gesundheitskompetenz: Einführung in die Ernährungspsychologie. Lecture given within the Zertifikatsprogramm "Gesundheitskompetenz" at the Zentralen Einrichtung für Sprachen und Schlüsselqualifikationen (ZESS) der GeorgAugust-Universität Göttingen Germany.

- Hauck C (since 2017). Gesundheitskompetenz: Vegan, Vegetarisch, Paleo - Ernährungsstile unter der Lupe. Lecture given within the Zertifikatsprogramm "Gesundheitskompetenz" at the Zentralen Einrichtung für Sprachen und Schlüsselqualifikationen (ZESS) der GeorgAugust-Universität Göttingen Germany.

- Hauck C, Ellrott T (since 2015). Einführung in die Ernährungspsychologie. Lecture given for the Departments of Psychology and Medicine, Göttingen, Germany. 


\section{Supervision and Mentoring}

- Ellenbroeck A. (2017) Bachelor thesis. Nutrition styles - a comparison between students from Germany, the Netherlands and New Zealand

- Heinrich T. (2016/2017) Master thesis. Hydratationsstatus von Fußballern - ein Vergleich zwischen männlichen und weiblichen Athleten

\section{Conferences and Workshops}

- Carolin Hauck, Annegret Weiß, Erica M. Schulte, Adrian Meule, Thomas Ellrott (2017) Food Addiction und nicht-nutritive Parameter des Essverhaltens In: Deutsche Adipositas Gesellschaft (DAG) e.V. (2017) Adipositas - mehr (als) Gewicht 33. Jahrestagung der Deutschen Adipositasgesellschaft vom 28.-30.09.2017 in Potsdam, Hogrefe

- Carolin Hauck, Melanie Schipfer, Brian Cook, Thomas Ellrott (2017) Food Addiction nicht nur bei Adipositas?! - Zum Zusammenhang zwischen der potentiellen neuen Essstörung Food Addiction, etablierten Essstörungen und Sportsucht In: Deutsche Adipositas Gesellschaft (DAG) e.V. (2017) Adipositas - mehr (als) Gewicht 33. Jahrestagung der Deutschen Adipositasgesellschaft vom 28.-30.09.2017 in Potsdam, Hogrefe

- Hauck C, Schipfer M, Ellrott T (2017): 'Food Addiction', exercise dependency and perfectionism in German athletes In: Zuber, C., Schmid, J., Schmidt, M, Wegner, M. \& Conzelmann, A. (Hrsg.). (2017). Gelingende Entwicklung im Lebenslauf. Abstractband der 49. Jahrestagung der Arbeitsgemeinschaft für Sportpsychologie (asp) vom 25. bis 27. Mai 2017 in Bern. Bern: Universität Bern, Bern Open Publishing. ISBN: 978-3-906813-42-4 [e-print] DOI: 10.7892/boris.99636

- Hauck, C., Weiß, A., Ellrott, T. (2017) The phenomenon of 'food addiction': Relationship between 'food addiction', eating behavior, health status and score of binge eating in a morbidly obese German sample, p.150, In: 24th European Congress on Obesity (ECO2017), Porto, Portugal, May 17-20, 2017: Abstracts, Obes Facts 2017;10(suppl 1):1-259, https://doi.org/10.1159/000468958

- Hauck C, Weiß A and Ellrott T (2016): Addictive-like eating behavior: Which are the most prevailing symptoms within the German population applying the YFAS 2.0? Obesity Facts 2016, Vol. 9, Suppl. 1., p. 237 Poster accepted for the European Conference on Obesity (ECO), Gothenborg, Sweden

- Hauck C, Weiß A and Ellrott Thomas (2016): Distribution of 'Food Addiction' among the German population: A cross-sectional study using the YFAS 2.0 in a representative sample. Obesity Facts Vol. 9, Suppl. 1., p. 238 Poster accepted for the European Conference on Obesity (ECO), Gothenborg, Sweden

- Weiß A, Hauck C and Ellrott T (2016): Addictive-like eating behavior in the German population: A cross-sectional study using the YFAS 2.0 in a representative sample. Obes. Rev., Vol. 17, p. 94 Poster accepted for the International Conference on Obesity (ICO), Vancouver, Canada

- Austel A, Hauck C, Ranke C, Wagner N, Görge J, Ellrott T (2015) Weight loss with a modified Mediterranean type diet using fat modification through neutral and butter flavored canola oil, walnuts and walnut oil. Poster presented at European Conference on Obesity (ECO), Prague, Czech Republic 
Talks

- Hauck C (scheduled for 2018) Relationship between 'Food Addiction', eating disorders and exercise dependence, talk within the session Exercise Dependence in Muscle Dysmorphia and Eating Disorders at the International Conference on Behavioral Addictions , Cologne, Germany

- Hauck C (2018) Food Addiction - möglicherweise eine neue Essstörung?! Talk for the Session: Nutrition matters! - Orthorexie, Food addiction \& Adipositas at the $6^{\text {th }}$ scientific congress of the German Nutrition Society for Eating Disorders, March 2018, Munich, Germany

- Hauck C (2018) Der Zusammenhang von Ernährung, Genuss und Gesundheit aus Sicht des Konsumenten Die Institut für Ernährungspsychologie und Lieferando.de Genussstudie 2017, Talk within Frühjahrsfachtagung 2018, Hannover, Germany

- Hauck C (2018) „Genuss und gesunde Ernährung“. Talk within the „Gesundheitszertifikat“ at Georg-August University Göttingen, Germany

- Hauck C (2017) „Genuss und gesunde Ernährung - in jedem Alter“. Talk for Heimvolkshochschule Mariaspring e.V.

- Hauck C (2017) Der Zusammenhang von Ernährung, Genuss und Gesundheit aus Sicht des Konsumenten Die Institut für Ernährungspsychologie und Lieferando.de Genussstudie 2017, Talk for the VFED (Verband fuer Ernaehrung und Diaetetik e.V.) Symposium, Aachen, Germany

- Hauck C (2017) „Jeder Bissen ein Gewissensbissen?! - Genuss und gesunde Ernährung“. Talk for university medicine Goettingen, Germany

- Hauck C (2017) „Süchtig nach Schokolade/Chips - Realität vs. Mythos?“. Talk within the "Gesundheitszertifikat" at Georg-August University Göttingen, Germany

- Hauck C (2017) Food Addiction - suchtartiges Essverhalten. Talk within the Master's course Oecotrophology at the Christian-Albrechts-Universität zu Kiel, Germany

- Hauck C (2016) Die Prävalenz von suchtartigem Essverhalten in Deutschland. Talk for the VFED (Verband fuer Ernaehrung und Diaetetik e.V.) Symposium, Aachen, Germany

- Hauck C (2016) Prävalenz von Food Addiction bei Patienten vor bariatrischer Chirurgie im Vergleich zur Normalbevölkerung. Talk for the obesity days (DAG) in Frankfurt, Germany

- Hauck C (2016) Die Prävalenz von suchtartigem Essverhalten in Deutschland. Talk for the obesity days (DAG) in Frankfurt, Germany

- Hauck C (2015) Zur Definition von Mediterranen Diäten. Talk given at the German Conference on Obesity, Berlin, Germany

\section{Reviews}

Review for the journal: European Eating Disorders Review

\section{Activities and Awards}

- Honorary badge in sports of the city of Goettingen (Sportplakette der Stadt Göttingen) (2017)

- TeamTeaching-Zertifikat, 2017/2018, Hochschuldidaktik, University of Goettingen, Goettingen, Germany 
- DAG-Nachwuchsstipendium für DAG-Kongress 2017 im Rahmen der Tätigkeit des Jungen Netzwerks Adipositas

- $\quad$ asp-Nachwuchsworkshop 2017, May 23-25, 2017, Bern, Suisse

- EASO NIU Summer School: Obesity - A Multi-Systemic Disease - EASO, June 29th - July 1st, 2016 Lisbon, Portugal

- EOS2016 Travel Grant for participation in the European Obesity Summit, 1 -4 June, 2016, Gotenborg, Sweden

- Conference Grant of the International Office, Georg-August Universität Göttingen, Stiftung öffentlichen Rechts, for participation in the International Conference on Obesity (ICO), Vancouver, Canada

- Conference Grant of Universitätsbund Göttingen e.V. for participation in the International Conference on Obesity (ICO), Vancouver, Canada

- Research Funding, Institut Danone Ernährung für Gesundheit e.V., 2015, „Food Addiction/Eating Addiction“, Project Number 2015/9

- International Summer School in Nutritional Epidemiology, August 10 to August 21, 2015, German Institute of Human Nutrition, Potsdam Rehbrücke

- Honorary award of the rectorate of University of Muenster (Ehrenpreis des Rektorates der Universität und FH Münster) (2014): German Student Championship in triathlon (team)

- Athlete of the year (Sportlerin des Jahres) $(2007,2014)$, Haßfurt

\section{Languages}

German: $\quad$ native language

English: advanced skills

French: intermediate skills

\section{Hobbies}

Triathlon, running, rock climbing, travelling and baking 


\section{Eidessstattliche Erklärung}

\section{E rk I ärunge n}

1. Hiermit erkläre ich, dass diese Arbeit weder in gleicher noch in ähnlicher Form bereits anderen Prüfungsbehörden vorgelegen hat.

Weiter erkläre ich, dass ich mich an keiner anderen Hochschule um einen Doktorgrad beworben habe.

Göttingen, den

(Unterschrift)

2. Hiermit erkläre ich eidesstattlich, dass diese Dissertation selbständig und ohne unerlaubte Hilfe angefertigt wurde.

Göttingen, den

(Unterschrift) 